\title{
Histórias das ciências, epistemologia, gênero e arte ensaios para a formação de professores
}

\author{
Breno Arsioli Moura \\ Thaís Cyrino de Mello Forato \\ (orgs.)
}

\section{SciELO Books / SciELO Livros / SciELO Libros}

MOURA, B. A., and FORATO, T. C. M., comps. Histórias das ciências, epistemologia, gênero e arte: ensaios para a formação de professores [online]. São Bernardo do Campo, SP: Editora UFABC, 2017, 268 p. ISBN 978-85-68576-84-7. https://doi.org/10.7476/9788568576847.

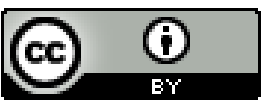

All the contents of this work, except where otherwise noted, is licensed under a Creative Commons Attribution 4.0 International license.

Todo o conteúdo deste trabalho, exceto quando houver ressalva, é publicado sob a licença Creative Commons Atribição 4.0.

Todo el contenido de esta obra, excepto donde se indique lo contrario, está bajo licencia de la licencia Creative Commons Reconocimento 4.0. 


\section{HISTÓRIAS DAS CIÊNCIAS, EPISTEMOLOGIA, GÊNERO E ARTE}

Ensaios para a Formação de Professores 


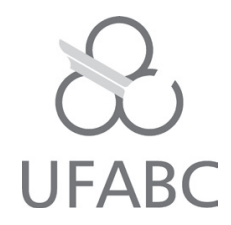

UNIVERSIDADE FEDERAL DO ABC

Prof. Dr. Klaus Werner Capelle - Reitor

Prof. Dr. Dácio Roberto Matheus - Vice-Reitor

Editora da UFABC

Profa. Dra. Adriana Capuano de Oliveira - Coordenação

Cleiton Fabiano Klechen

Natalia Gea 


$$
\begin{gathered}
\text { BRENO ARSIOLI MOURA } \\
\text { THAÍS CYRINO DE MELLO FORATO }
\end{gathered}
$$

(Organizadores)

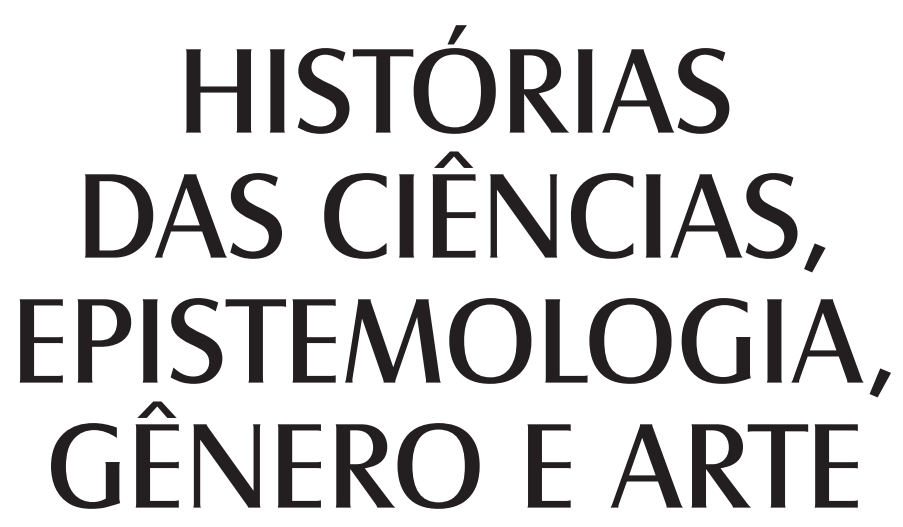

Ensaios para a Formação de Professores

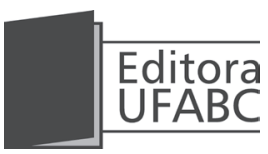

São Bernardo do Campo - SP 2017 
(C) Copyright by Editora da Universidade Federal do ABC (EdUFABC)

Todos os direitos reservados.

\section{Revisão}

Janice Souza

\section{Projeto gráfico e diagramação}

Rita Motta, sob coordenação da Gráfica e Editora Copiart.

\section{Impressão}

Gráfica e Editora Copiart

\section{CATALOGAÇÃO NA FONTE}

SISTEMA DE BIBLIOTECAS DA UNIVERSIDADE FEDERAL DO ABC

Responsável: Marciléia Aparecida de Paula CRB: 8/8530

Histórias das ciências, epistemologia, gênero e arte : ensaios para a formação de professores / Organizado por Breno Arsioli Moura e Thaís Cyrino de Mello Forato

— São Bernardo do Campo, SP : EdUFABC, 2017.

viii, 280 p. : il.

ISBN: 978-85-68576-59-5

1.História da Ciência. 2. Epistemologia. 3. Ciência - Estudo e Ensino I. Moura, Breno Arsioli, org. II. Forato, Thais Cyrino de Mello, org. 


\section{AGRADECIMENTOS}

Agradecemos aos autores que contribuíram para a constituição desta obra, desde sua primeira concepção, em 2015. Não há dúvidas de que suas propostas enriquecem o diálogo entre áreas distintas, e estas, unidas, têm muito a contribuir para a formação de nossos professores. Esperamos que o resultado desse esforço mútuo possa oferecer uma fonte de conhecimento para o leitor.

Alguns capítulos apresentam uma parte dos resultados desenvolvidos por pesquisadores do grupo História das Ciências na Educação Científica (UNIFESP), em colaboração com pesquisadores de outras instituições (UFABC, CEFET-RJ, UERJ, USP), no âmbito de um projeto de pesquisa com apoio do CNPq (Edital Universal 2014) $)^{1}$. Por essa razão, agradecemos o apoio desta entidade, que permitiu a constituição de parcerias entre alguns dos colaboradores e fundamentou vários capítulos dessa obra.

Agradecemos à Editora da UFABC pela oportunidade de publicar este livro.

${ }^{1}$ O projeto A história e a filosofia das ciências no ensino de ciências: implementando e avaliando propostas na formação inicial de professores integra sete pesquisadores de seis universidades. 


\section{SUMÁRIO}

INTRODUÇÃO. HISTÓRIA E EPISTEMOLOGIA DAS CIÊNCIAS NA FORMAÇÃO DE PROFESSORES

Thaís Cyrino de Mello Forato | Breno Arsioli Moura

\section{Capítulo 1}

O ENIGMA DO PULGÃO 11

Filipe Faria Berçot | Maria Elice de Brzezinski Prestes

\section{Capítulo 2}

ASPECTOS DA NATUREZA DA CIÊNCIA NAS PESQUISAS DE IRVING LANGMUIR (1881-1957) RELACIONADAS COM A ESTRUTURA DA MATÉRIA

Hélio Elael Bonini Viana

\section{Capítulo 3}

O CASO DA VACINA TRÍPLICE E O AUTISMO: O QUE OS ERROS NOS ENSINAM SOBRE OS ASPECTOS DA NATUREZA DA CIÊNCIA 53

Renato Barboza | Simone Alves de Assis Martorano

\section{Capítulo 4}

O PROCESSO CRIATIVO DE AMPÈRE NA ELABORAÇÃO DA ELETRODINÂMICA 71 Ivã Gurgel

\section{Capítulo 5}

UMA BOMBA EM VERSO, PROSA E CANÇÃO: HISTÓRIA, ARTE E TECNOLOGIA NAS AULAS DE FÍSICA 93

Winston Gomes Schmiedecke | Paulo Alves Porto 


\section{Capítulo 6}

A BUSCA DE DIÁLOGOS ENTRE CIÊNCIA E ARTE COMO FORMA DE CONSTRUIR CAMINHOS DE COMPREENSÃO DO PENSAMENTO CIENTÍFICO 115

José Cláudio Reis | Andréia Guerra | Marco Braga

\section{Capítulo 7}

CIÊNCIA E SOCIEDADE: RETRATOS DA HISTÓRIA DA TERMODINÂMICA NA ARTE.

Danielle Beatriz de Sousa Borges | Thaís Cyrino de Mello Forato

\section{Capítulo 8}

A CIÊNCIA COMO VILÃ NO CINEMA: UM ESTUDO A PARTIR DA LINGUAGEM CINEMATOGRÁFICA 163

Aennder Ferreira de Sousa | Breno Arsioli Moura

\section{Capítulo 9}

DE VOLTA PARA O FUTURO: A VISÃO DE CIENTISTA

NO CINEMA

Suseli de Paula Vissicaro | Márcia Helena Alvim

\section{Capítulo 10}

FRANCIS BACON E A CONSTITUIÇÃO DO IDEAL CIENTÍFICO MODERNO

Luciana Zaterka | Guilherme de Lucas A. Barbosa

\section{Capítulo 11}

A NOVA FACE DO MUNDO CELESTE NAS IMAGENS DA LUNETA DE GALILEU

Paulo Tadeu da Silva | Paluana Curvelo Luquiari

\section{Capítulo 12}

CIÊNCIA FEMINISTA, HISTÓRIA E EPISTEMOLOGIA

Clara Guimarães | Graciela de Souza Oliver

\section{Capítulo 13}

GÊNERO E CIÊNCIA: ANÁLISE DE UMA POSSÍVEL CIÊNCIA FEMINISTA

Andréia Moreira da Silva | Karla Rampim Xavier | Ana Maria Dietrich

SOBRE OS AUTORES 269 


\section{INTRODUÇÃO \\ HISTÓRIA E EPISTEMOLOGIA DAS CIÊNCIAS \\ NA FORMAÇÃO DE PROFESSORES}

Thaís Cyrino de Mello Forato

Breno Arsioli Moura

A proposta deste livro nasceu do desejo de reunir um conjunto de reflexões sobre as potencialidades da história e da epistemologia das ciências (HEC) para o ensino de ciências e para outras áreas afins do saber. Seus capítulos trazem os resultados de pesquisas em diferentes perspectivas, realizadas por pesquisadores com distintos percursos formativos e diferentes abordagens da ciência e para o ensino.

O público-alvo deste livro é o professor, em sua formação inicial ou continuada. Seus capítulos buscam contribuir para promover uma formação crítica, reflexiva e transformadora (MOURA, 2012; PIMENTA, 2012) e contemplam o propósito de incentivar uma boa prática docente. Os vários diálogos entre as ciências da natureza com alguns de seus aspectos epistêmicos e sua relação com o contexto cultural de seu desenvolvimento permitem fomentar o olhar reflexivo, inquietador e crítico. Assim, dentre os diversos objetivos formativos que cada capítulo permite mobilizar, o formador de professores pode, também, atribuir intencionalidade ao conteúdo dessa obra, em processos de formação pautados na concepção de Educação em Ciências 
como instrumento para promoção dos Direitos Humanos (D’AMBRÓSIO, 2000; OLIVEIRA; QUEIROZ, 2015).

A inclusão de conteúdos metacientíficos no ensino das ciências não é novidade. A história das ciências, por exemplo, consta no currículo dos cursos para a formação de professores em diversos países. No Brasil, ela já estava presente desde a reforma Francisco Campos, de 1931. Cada época, entretanto, tem seus próprios pressupostos formativos ligados a essa recomendação, bem como perspectivas historiográficas peculiares. Atualmente, as diretrizes curriculares para a formação de professores indicam que é necessário conhecer o processo histórico de elaboração da ciência, ou seja, inserir discussões epistemológicas, o que impõe a presença de sua história (PORTO, 2010). Desse modo, este livro busca contribuir para a introdução da HEC na formação de professores e, também, oferecer uma diversidade de perspectivas que pretendem constituir-se materiais para seus formadores.

Essa iniciativa acompanha o cenário atual, pois engloba e pondera sobre as problemáticas atuais da relação entre HEC e ensino de ciências (ALLCHIN; ANDERSEN; NIELSEN, 2014). Nas últimas décadas, a introdução de conteúdos históricos e epistemológicos da ciência tem se tornado constante nos diversos contextos de ensino. Na literatura especializada, é possível encontrarmos boas referências que abordam a importância desses conteúdos para a formação de professores ${ }^{1}$, bem como propostas para a sala de aula, implementadas no contexto brasileiro ${ }^{2}$.

${ }_{1}^{1}$ Por exemplo: Colagrande, Martorano e Arroio (2015); Forato (2013); Gómez-Martínez (2016); Höttecke e Silva (2009); Martorano (2012); Oliveira e Drummond (2015); Peduzzi, Martins e Ferreira (2012); Pietrocola e Gurgel (2016); Silva (2006); dentre outras.

2 Bagdonas (2015); Forato, Martins e Pietrocola (2008); Morais e Guerra (2013); vários capítulos no livro de Silva e Guerra (2015); Silva e Moraes (2015); Silva (2013); Souza (2014) etc. 
Contudo, o amadurecimento propositivo a que temos assistido não eliminou - e nem poderia - as recorrentes dificuldades intrínsecas à formação de professores. Falta de preparo de docentes formadores, conflitos com a cultura escolar, falta de tempo didático e de materiais adequados ainda são alguns dos obstáculos a serem superados (BORGES, 2016; HÖTTECKE; SILVA, 2011). Acreditamos que é fundamental promover e apoiar diferentes iniciativas, envolvendo a HEC no ensino, que visem subsidiar os formadores de professores para lidar com tais desafios.

Nesse contexto, pretendemos contribuir com distintas possibilidades para abordagens da HEC no ensino, seja pela discussão de episódios históricos, ou pela relação das ciências com diversas manifestações das artes (GUERRA; BRAGA; REIS, 2009; ZANETIC, 2006) ou, ainda, reflexões no tema gênero e ciência, que se constituem mais uma oportunidade para explorar novos direcionamentos e fomentar novas reflexões sobre a importância da HEC em contextos de formação de professores.

Ao se propor a congregar diferentes discussões nas vertentes da HEC, este livro visa a mostrar quão diversas são as possibilidades dessa interlocução na formação de professores. Nesse sentido, o professor, assim como seu formador, não somente poderá fomentar uma visão histórica e epistemológica mais crítica como também desenvolver sua própria prática em sala de aula, sendo instigado a pensar na adequação didática dessas discussões aos diferentes contextos escolares.

Esses diferentes enfoques oferecem material também para se discutir a inexistência de uma única visão sobre a natureza das ciências, no âmbito do ensino de ciências (MOURA, 2014; DAGHER; ERDURAN, 2016). Além disso, possibilitam exemplificar a historicidade das ciências, mostrando diferentes caminhos que a humanidade constrói, em diferentes épocas e culturas, 
para elaborar explicações sobre o mundo natural. Essas distintas possibilidades oferecem apoio para o formador de professores lidar com diferentes desafios e obstáculos nos usos didáticos da HEC (FORATO; MARTINS; PIETROCOLA, 2012).

O livro apresenta, assim, a ciência como um campo que congrega saberes em que conceitos, modelos, teorias e leis possuem um desenvolvimento sócio-histórico. Ele busca oferecer, para a formação de professores, possibilidades para que se pense a didatização da HEC, o que requer assumir um caráter transdisciplinar, na perspectiva defendida por D’Ambrósio (2009), pela diversidade de campos que mobiliza e pelo modo como tais saberes devem ser amalgamados, tornando-se praticamente impossível separá-los.

Consideramos essa multiplicidade de abordagens como essencial para a construção de uma visão mais adequada sobre a HEC pelos professores. No fim, todas nada mais são que subsídios para que os professores e seus formadores promovam uma emancipação intelectual e um maior senso crítico.

\section{Referências}

ALLCHIN, Douglas; ANDERSEN, Hanner Moller; NIELSEN, Keld. Complementary approaches to teaching nature of science: integrating student inquiry, historical cases, and contemporary cases in classroom classes. Science Education, v. 98, n. 3, p. 461-486, 2014.

BAGDONAS, Alexandre. Controvérsias envolvendo a natureza da ciência em sequências didáticas sobre cosmologia. 2015. 266 f. Tese (Doutorado em Ensino de Ciências) - Programa de Pós-Graduação 
Interunidades em Ensino de Ciências, Universidade de São Paulo, São Paulo, 2015. Disponível em: <http://www.teses. usp.br/teses/disponiveis/81/81131/tde-14092015-112555/ pt-br.php>. Acesso em: 5 abr. 2016.

BORGES, Danielle Beatriz de Sousa. A construção de uma abordagem histórica para o ensino de termodinâmica: Sadi Carnot e o estudo da Máquina Térmica. 2016. 111 f. Dissertação (Mestrado em Ensino, História e Filosofia das Ciências e Matemática) - Programa de Pós-Graduação em Ensino, História e Filosofia das Ciências e Matemática, Universidade Federal do ABC, Santo André, 2016.

COLAGRANDE, Elaine A.; MARTORANO, Simone Alves de Assis; ARROIO, Agnaldo. Reflections about teaching nature of science mediated by images. Natural Science Education, v. 12, n. 1, p. 7-19, 2015. Disponível em: <http://oaji.net/ articles/2015/514-1429783674.pdf>. Acesso em: 5 abr. 2016.

DAGHER, Zoubeida R.; ERDURAN, Sibel. Reconceptualizing the Nature of Science for Science Education. Why Does it Matter? Science \& Education, v. 25, p. 147-164, mar. 2016.

D’AMBRÓSIO, Ubiratan. Transdisciplinaridade. São Paulo: Ed. Palas Athena, 2009.

D’AMBROSIO, U. Paz, educação e etnomatemática. Teoria e Prática da Educação, v. 4, n. 8, p. 15-33, 2001. Disponível em: <http://etnomatematica.org/articulos/Ambrosio2.pdf>. Acesso em: 10 nov. 2016.

FORATO, Thaís Cyrino de Mello. Preparação de professores para problematização da pseudohistória em materiais didáticos. 
Enseñanza de las Ciencias, v. Extra, p. 1316-1321, 2013.

.; MARTINS, Roberto de Andrade; PIETROCOLA, Maurício. Enfrentando obstáculos na transposição didática da História da Ciência para a sala de aula. In: PEDUZZI, Luiz O. Q.; MARTINS, André Ferrer P.; FERREIRA, Juliana Mesquita Hidalgo (Org.). Temas de História e Filosofia da Ciência no Ensino. Natal: EdUFRN, 2012.

; . Teorias da luz e Natureza da ciência: elaboração e análise de curso aplicado no ensino médio (completo). In: ENCONTRO DE PESQUISA EM ENSINO DE FÍSICA - EPEF, 11., 21-24 out. 2008, Curitiba. Anais eletrônicos... Curitiba: UTFPR, 2008. Disponível em: <http://www.sbf1.sbfisica.org.br/eventos/ epef/xi/sys/resumos/T0172-1.pdf>. Acesso em: 5 abr. 2016.

GUERRA, Andréia; BRAGA, Marco; REIS, José Cláudio. Física e Arte: Uma Proposta para a Compreensão Cultural da Ciência. Enseñanza de las Ciencias, v. extra, p. 1763-1766, 2009.

GÓMEZ-MARTíNEZ, Yadrán. Configurando narrativas históricas y preguntas directrices para un abordaje sistémica sobre la revolución copernicana: una propuesta para fortalecer la alfabetización Científica. 2015. 210 f. Dissertação (Mestrado em Educação) - Faculdade de Educação, Universidade de São Paulo, São Paulo, 2015.

HÖTTECKE, Dietmar; SILVA, Cibelle Celestino. Why implementing history and philosophy of science in school science education is a challenge: an analysis of obstacles. Science \& Education, v. 20, n. 3/4, p. 293-316, aug. 2011.

MARTORANO, Simone Alves de Assis. A transição progressiva dos modelos de ensino sobre cinética química a partir do 
desenvolvimento histórico do tema. 2012. 360 f. Tese (Doutorado em Ensino de Química) - Instituto Química, Instituto de Física, Instituto de Biociências, Faculdade de Educação, Universidade de São Paulo, São Paulo, 2012.

MORAIS, Angelita; GUERRA, Andreia. História e a filosofia da ciência: caminhos para a inserção de temas física moderna no estudo de energia na primeira série do Ensino Médio. Revista Brasileira de Ensino de Física, v. 35, n. 1, p. 1-9, jan./mar. 2013.

MOURA, Breno Arsioli. Formação crítico-transformadora de professores de Física: uma proposta a partir da História da Ciência, 2012. 310 f. Tese (Doutorado em Ensino e Física) Faculdade de Educação, Instituto de Física, Instituto de Química e de Biociências, Universidade de São Paulo, São Paulo, 2012.

O que é natureza da ciência e qual sua relação com a história e a filosofia da ciência. Revista Brasileira de História da Ciência, v. 7, n. 1, p. 32-46, 2014.

OLIVEIRA, Roberto Dalmo Varallo Lima de; QUEIROZ, Gloria Regina Pessoa Campello. Olhares sobre a (in)diferença: formar-se professor de ciências a partir de uma perspectiva de Educação em Direitos Humanos. São Paulo: Editora Livraria da Física, 2015.

OLIVEIRA, Wesley Costa de; DRUMMOND, Juliana M. Hidalgo F. Refletindo sobre desafios à inserção didática da História e Filosofia da Ciência em oficina de formação docente. Alexandria, v. 8, n. 3, p. 151-179, 2015.

PEDUZZI, Luiz O. Q.; MARTINS, André Ferrer P.; FERREIRA, Juliana Mesquita Hidalgo (Org.). Temas de História e Filosofia da Ciência no Ensino. Natal: EdUFRN, 2012. 
PIETROCOLA, Maurício; GURGEL, Ivã (Org.). Crossing the Border of Traditional Science Curriculum: innovative teaching and learning in Science Basic Education. Rotterdam: Sense Publishers, 2016.

PIMENTA, Selma Garrido. Professor reflexivo: construindo uma crítica. In:___ _ GHEDIN, Evandro (Org.). Professor Reflexivo no Brasil: gênese e crítica de um contexto. 7. ed. São Paulo: Cortez Editora, 2012. p. 20-62.

PORTO, Paulo Alves. História e Filosofia da Ciência no Ensino de Química: em busca dos objetivos educacionais da atualidade. In: SANTOS, Wildson Luiz P. dos; MALDANER, Otavio Aloisio (Org.). Ensino de Química em Foco. Ijuí: Editora Unijuí, 2010. p. 159-180.

SILVA, Ana Paula Bispo da Silva; GUERRA, Andréia (Org.). História da Ciência e Ensino: Fontes primárias e propostas para a sala de aula. São Paulo: Editora Livraria de Física, 2015.

SILVA, Cibelle Celestino (Org.). Estudos de história e filosofia das ciências: subsídios para aplicação no ensino. São Paulo: Editora Livraria da Física, 2006.

SILVA, Hebert Roberto Araujo; MORAES, Andreia Guerra. O estudo da espectroscopia no ensino médio através de uma abordagem histórico-filosófica: possibilidade de interseção entre as disciplinas de Química e Física. Caderno Brasileiro de Ensino de Física (Online), v. 32, p. 378-406, ago. 2015.

SILVA, Tatiana Tavares da. Darwin na sala de aula: replicação de experimentos históricos para auxiliar a compreensão da teoria evolutiva. 2013. 184 f. Dissertação (Mestrado em Ensino 
de Ciências) - Programa de Pós-Graduação Interunidades em Ensino de Ciências, Universidade de São Paulo, São Paulo, 2013.

SOUZA, Rosa Andréa Lopes de. A viagem de Wallace ao Brasil: uma aplicação da história da ciência no ensino de biologia. 2014. 375 f. Dissertação (Mestrado em Ensino de Ciências) - Programa de Pós-Graduação em Ensino de Ciências, Universidade de São Paulo, São Paulo, 2014.

ZANETIC, João. Física e Arte: uma ponte entre duas culturas. Pro-Posições, v. 17, n. 1, p. 39-57, 2006. 


\section{O ENIGMA DO PULGÃO}

Filipe Faria Berçot Maria Elice de Brzezinski Prestes

\section{Introdução}

Este capítulo apresenta o episódio histórico da "descoberta" da multiplicação sem acasalamento (partenogênese) em pulgões, realizada pelo naturalista genebrês Charles Bonnet (1720-1793) na primeira metade do século XVIII. O fenômeno da geração dos seres vivos ocupou o centro das atenções dos estudos de história natural naquele século. O impacto dessa descoberta, de uma forma de reprodução animal antes impensável, causou rearranjo conceitual do tema e consolidação de novos modelos metodológicos de investigação. Assim, além da descoberta mencionada, o capítulo salienta regras, procedimentos e técnicas de observação e experimentos que se caracterizaram como elementos de inovação metodológica no campo de estudo do funcionamento dos organismos vivos na época.

O capítulo realça, ainda, as relações de Bonnet com um naturalista já afamado do período, o francês René Antoine Ferchault de Réaumur (1683-1757). Dentre os diversos estudos realizados por Réaumur, foi expressiva a sua contribuição para o 
conhecimento dos "insetos", termo empregado na época para referir a toda sorte de organismos pequenos (PRESTES, 2008, p. 270). Além de difundir conhecimentos sobre a "insectologia", as publicações de Réaumur aspiravam também impelir a curiosidade e estimular novas investigações no âmbito da história natural voltada aos organismos inferiores. Será mostrado, então, de que modo o apelo de Réaumur atraiu as atenções do jovem Bonnet, ilustrando as redes de relações acadêmicas no século XVIII.

A abordagem histórica é acompanhada de discussões que subsidiam a sua incorporação em práticas de ensino de biologia, da escola básica e/ou ensino superior. Dentre os vários benefícios que a literatura da área (MATTHEWS, 1994; MARTINS, 1998; MARTINS, 2006) indica sobre a utilização da história da ciência no ensino estão a facilitação para a aprendizagem significativa de conhecimento científico atual e o desenvolvimento, por meio de abordagem explícita e reflexiva, de visão informada e fundamentada sobre o modo como a ciência funciona (METZ, 2007; ALLCHIN, 2012, 2013).

Assim, o episódio histórico é aqui discutido com o objetivo de constituir material instrucional alternativo segundo dois objetivos principais: facilitar a aprendizagem de conceitos biológicos importantes, no caso, a partenogênese, relacionada ao tema da reprodução assexuada de animais; e promover discussão explícita e reflexiva de aspectos metacientíficos, no caso, questões relacionadas à dimensão "sociocultural" da ciência, que, juntamente às dimensões "observacional" e "conceitual", constitui o que Allchin (2013) chamou de "Ciência Integral" (Whole Science). A abordagem de Allchin foi adotada neste trabalho como uma proposta de superação do enfoque sobre listas "consensuais" de aspectos de Natureza da Ciência (ERDURAN; DAGHER, 2016, p. 1). 
O estudo histórico seguiu a metodologia de pesquisa em história da ciência, com base na análise de fontes primárias dos autores já mencionados. De Bonnet, foi analisado, especialmente, o Traité d'Insectologie ou Observation sur lês Pucerons (Tratado de insetologia ou observações sobre pulgões), publicado em 1745. De Réaumur, foi realizada análise dos textos sobre as lagartas processionárias e pulgões contidos nos volumes 1 e 3 de suas Memóires pour servir a l'histoire des insectes (Memórias para servir à história dos insetos), obra com seis volumes publicados entre 1734 e 1742. Paralelamente, foi realizada a análise das fontes secundárias pertinentes, isto é, obras de historiadores da ciência que se debruçaram sobre as contribuições dos naturalistas mencionados, servindo como guias de orientação para a leitura, auxiliando na contextualização epistêmica e social de suas obras. Os percursos particulares da formação, carreira e produção acadêmica dos autores foram levantados junto a obras biográficas e enciclopédicas.

Além disso, foram consultados trabalhos recentes de pesquisadores ocupados com a inserção da história da ciência no ensino, além de publicações de especialistas das ciências biológicas para comparação com o conhecimento atual sobre os fenômenos descritos.

\section{Bonnet, Réaumur e a insetologia}

Charles Bonnet era membro de uma família de magistrados aristocratas de Genebra. Seguindo a orientação de seu pai, obteve o título de Doutor em Lei aos 23 anos, mas nunca desempenhou a profissão de advogado. Desde a adolescência, o seu grande fascínio e vocação foi pela história natural, sobretudo a história natural dos insetos. 
A história a seguir narra alguns dos acontecimentos que levaram Bonnet a se tornar o correspondente mais jovem da Academia de Ciências de Paris, um conceituado centro de estudos e disseminação do conhecimento em história natural da época.

Aos 17 anos, Bonnet não apenas realizava leituras, mas repetia e conduzia novas observações com insetos sugeridas nas obras de Réaumur: "Observei pela primeira vez em maio de 1737 e vi tudo aquilo que o Sr. Réaumur contou em detalhes [...]" (BONNET, 1779, p. 13). Um estudo em particular, sobre os hábitos da "lagarta processionária"1 (RÉAUMUR, 1736, p. 161) levou Bonnet a desenvolver uma forma sistemática de observação. A Figura 1 ilustra as lagartas processionárias observadas por Réaumur.

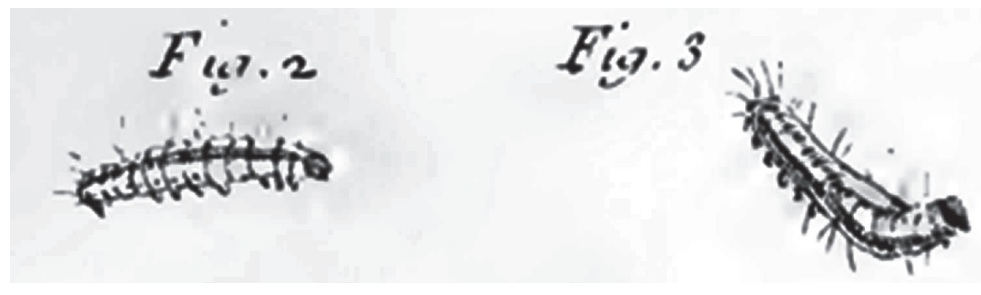

Figura 1 - llustrações das lagartas processionárias

Fonte: Réaumur (1736, prancha 10, p. 211).

No ano seguinte, Bonnet encontrou um galho contendo um ninho dessas lagartas e decidiu levá-lo para casa, alojando-o na parte externa da janela de seu quarto. Dessa forma, ele garantia que ficasse em um ambiente semelhante àquele na natureza, "ao contrário do que faziam os naturalistas, confinando

\footnotetext{
1 Lagarta processionária (Thaumetopoea pityocampa), denominada por Réaumur de Livrée é uma espécie amplamente distribuída na França e comumente encontrada sobre pinheiros (FITZGERALD, 2003).
} 
insetos em potes de vidro" (BONNET, 1779, p. 14). No decurso de alguns meses, Bonnet observou diversos comportamentos das lagartas, por exemplo: características morfológicas, reações a estímulos externos, como calor, luz e som, trocas de pele (hoje denominadas ecdises ou mudas) e a formação de casulos e crisálidas (BONNET, 1779, p. 14-28).

Uma peculiaridade dessas lagartas, relacionada ao próprio nome pelo qual eram reconhecidas, era o fato de elas caminharem a longas distâncias de seus ninhos, sempre em fila, "em procissão", e retornarem exatamente pelo mesmo caminho. Como esses insetos se orientavam por caminhos tão longos? Bonnet se propôs a entender como isso acontecia.

Eu sabia que as lagartas não eram desprovidas de visão, pois eu já tinha observado seus olhos com uma lupa [...]; mas, apesar disso, eu não estava muito seguro sobre o papel da visão dessas lagartas; e eu não estava convencido que seus olhos seriam o suficiente para guiá-las por caminhos tão diferentes e distantes. (BONNET, 1779, p. 18-19)

Numa manhã, enquanto as lagartas saíam do ninho, Bonnet notou um brilho esbranquiçado refletido pelo sol sobre a janela. Ao olhar para a base da janela, ele percebeu um fio de seda ao longo da rota e constatou que esse fio era produzido pelas próprias lagartas. Ao longo do caminho esses fios formavam um tipo de "tapete de seda" que parecia servir como trilhos de orientação. Para ter certeza de que essa "tapeçaria" era, de fato, a responsável pela condução das lagartas, ele rompeu o trilho com seu próprio dedo. Chama a atenção, na descrição de Bonnet, o detalhamento da observação e o modo como expressa o comportamento do inseto com base nas atitudes e características humanas: 
Quando a lagarta que liderava a procissão chegou ao ponto onde o caminho foi interrompido, ela virou-se imediatamente, como se estivesse assustada: (...) à medida que as demais lagartas chegavam ao ponto rompido, paravam sua marcha e pareciam mais ou menos confusas. [...] Enfim, uma das lagartas, mais corajosa que as outras, ousou continuar e traçou um novo fio para restabelecer a rota, sendo logo acompanhada pelas outras. [...] Devo dizer, no entanto, que até que a rota fosse totalmente reparada, minhas lagartas ainda mostravam certa inquietude ao passar pelo ponto danificado. (BONNET, 1779, p. 21-22)

Bonnet repetiu outras vezes esse "experimento" simples, sempre obtendo os mesmos resultados. Aqui é importante enfatizar dois aspectos; o primeiro, de que, como seus contemporâneos, Bonnet usa o termo experimento naquele sentido baconiano de qualquer alteração do curso normal da natureza; o segundo, de que ele está adotando um procedimento, a repetição do experimento, que se constitui como regra metodológica entre os naturalistas do período. Também é digno de nota o discernimento de Bonnet sobre o fato novo agregado às observações de Réaumur:

O sr. Réaumur sabia que as processionárias cobriam seu caminho com fios [...], mas ele não havia percebido todos os usos dessa manobra. Ele acreditava que as lagartas cobriam o seu caminho porque era mais fácil marchar e agarrar em folhas e galhos cobertos de [fios] seda do que sobre folhas e galhos nus. (BONNET, 1779, p. 31)

Como leitor de Réaumur, Bonnet sabia que ele era um incentivador da disseminação da prática de estudos em história natural, reconhecendo a contribuição de colegas, colaboradores 
e auxiliares que enviavam toda sorte de organismos e relatos de observações (TERRALL, 2010, p. 573). Réaumur era bastante enfático nesse convite:

Qualquer interessado no progresso da história natural, que me julgar capaz de contribuir, pode me enviar presentes os quais receberei com apreciação; eu ficarei feliz em expressar publicamente, caso me façam a gentileza de enviar observações e insetos que lhes pareçam incomuns e que desejam que eu os estude. (RÉAUMUR, 1734, p. 51)

Bonnet animou-se a enviar uma correspondência ao naturalista francês, dando origem a 19 anos de trocas de cartas entre os dois.

Cabe assinalar que, nos séculos XVII e XVIII, as cartas eram uma forma bastante comum de comunicação entre estudiosos e constituíam modalidade padrão de disseminação do conhecimento. Devido ao caráter rápido, barato e seguro, ganharam um nicho duradouro na troca de informações (HATCH, 2000, p. 263). Mediante o uso do transporte por cavalos (em média $8 \mathrm{~km} / \mathrm{h}$ ) ou por barcos movidos a vento (15 km/h) (RODRIGUE; COMTOIS; SLACK, 2013, p. 15), dentro de poucas semanas, cartas poderiam ser enviadas e recebidas em toda a Europa, via combinação entre a remessa normal e a diplomática (HATCH, 2000, p. 263). Isso gerou a criação de redes de correspondência que, associadas às sociedades científicas emergentes da época, reforçaram os modos tradicionais de comunicação (livro impresso) e representaram uma inovação significativa (MCCLELLAN, 2008, p. 89). Além da transferência regular de informações, as remessas asseguravam também a troca de itens colecionáveis, espécimes e obras publicadas (LEONI, 2013, p. 507). 
Réaumur ilustra bem a formação dessas redes. O prestígio e sua posição acadêmica facilitaram o estabelecimento de uma grande rede internacional composta não apenas por outros naturalistas, mas também por coletores desconhecidos e estudiosos amadores. Ele recebia organismos vivos e conservados de vários lugares do mundo, escrevia instruções sobre métodos de observação, preparação e conservação dos espécimes (RATCLIFF, 2005, p. 233).

A rede de correspondências entre esses naturalistas é um exemplo que permite reflexões sobre a dimensão sociocultural da ciência como apontado por Allchin (2013). As correspondências se configuram, do ponto de vista das instituições, em torno de aspectos como "colaboração e competição entre os cientistas" e "formas de persuasão" utilizadas, enquanto, do ponto de vista da comunicação, elas indicam as "normas de manuseio de dados científicos" (ALLCHIN, 2013, p. 24).

Seguindo o espírito enciclopedista da época, Réaumur indica a percepção de que não conseguiria elucidar sozinho o estudo dos insetos. A "insectologia" dependia de recursos materiais e contribuição intelectual que teria que provir de diferentes pessoas e de lugares diversos. Ele almejava expandir os conhecimentos incomuns e singulares não apenas a respeito da morfologia e do comportamento dos insetos, mas também de seus aspectos úteis ou nocivos para a sociedade humana (TERRALL, 2010, p. 575).

$\mathrm{E}$ no que concerne à singularidade, outro pequeno inseto vinha, há tempos, intrigando naturalistas e curiosos - os pulgões ${ }^{2}$.

\footnotetext{
2 Afídeos, popularmente conhecido como pulgões, são insetos da ordem hemíptera, que vivem de uma dieta de seiva de plantas. Hoje se sabe que compreendem aproximadamente 4700 espécies entre três famílias principais: Aphididae, Adelgidae e Phylloxerida (DAVIS, 2012).
} 


\section{O enigma do pulgão}

No início do século XVIII, os naturalistas consideravam que a reprodução sexual em animais envolvia dois indivíduos que copulavam. Porém, desde o século anterior, alguns estudiosos acadêmicos e amadores realizaram observações do pulgão que pareciam indicar uma transgressão dessa regra, motivando diversas investigações sobre a reprodução desses organismos.

O holandês Johannes Goedaert ${ }^{3}$ (1617-1668) não conseguiu observar a cópula entre esses insetos, porém, ao notar a curiosa associação entre os pulgões e as formigas, considerou que os pulgões nasciam de um tipo de líquido que as formigas espalhavam sobre as plantas (PLATEAU, 1868, p. 20). O naturalista holandês Antonie Philips van Leeuwenhoek (1632-1723), mesmo não tendo encontrado nenhum macho entre os pulgões, afirmou que eles produzem "filhotes vivos", isto é, que nascem após serem formados no interior do corpo da mãe. Ele apenas mencionou esse fato, sem maiores explicações derivadas de observações ou experimentos (PHILLIPS, 1903, p. 295). Na Itália, o naturalista Giacinto Cestoni (1637-1718) havia afirmado que os pulgões eram hermafroditas, pois observou que geravam descendentes, mesmo sem jamais terem sido vistos copulando (PRESTES; MARTINS, 2014, p. 346). O francês Claude-Joseph Geoffroy (1685-1752) afirmou que uma espécie de pulgão com asas era vivípara, como indicara Leeuwenhoek. Ao observar o nascimento desses pulgões, Geoffroy percebeu que possuíam a mesma forma da mãe, porém sem asas; no entanto, ao se

\footnotetext{
${ }^{3}$ Goedaert publicou, entre 1662 e 1667, três volumes da obra Métamorphoses naturelles ou Histoire des insectes observée tres-exactement suivant leur nature \& leurs propriétés (Metamorfose natural ou história dos insetos observados na natureza e suas propriedades), incluindo observações sobre metamorfose em insetos (GOEDAERT, 1700).
} 
desenvolver, eles se tornavam alados (RÉAUMUR, 1737, p. 326). As observações de Geoffroy trouxeram um novo problema, pois era sabido, por meio de analogias com outros insetos, que indivíduos sem asas eram fêmeas, indivíduos com asas eram machos (RÉAUMUR, 1737, p. 324). As observações de Geoffroy com pulgões alados lançaram mais dúvidas sobre a história de geração desses pequenos insetos. Por sua vez, Réaumur dedicou-se intensamente ao estudo da história natural desses insetos, descrevendo os resultados das suas observações na nona memória do terceiro volume de suas Memoires pour servir a l'histoire des insectes, de 1737. Ao longo de 69 páginas, ele ofereceu detalhes morfológicos e hábitos de espécies diferentes de pulgões por meio de extensas, contínuas e variadas observações (RÉAUMUR, 1737, p. 283).

Os esforços de todos esses naturalistas não resolveram a questão. O mistério que ainda demandava solução trazia consigo novas incertezas. Diante delas, Réaumur perguntou: "Qual seria, afinal, o sexo dos pulgões com asas, e qual a serventia desses na família dos pulgões?" (RÉAUMUR, 1737, p. 324).

Para responder a questão, Réaumur tentou isolar um pulgão com asa a fim de observar o nascimento de um filhote, mas não teve sorte. Assim, ele empreendeu um novo procedimento:

Para se convencer que [esses pulgões alados] são vivíparos, basta pressionar próximo ao meio do ventre, forçando suavemente até que os pequenos corpos saiam pela parte de trás. Qualquer observador, usando uma lupa, que olhe os pequenos corpos, facilmente reconhecerá que os pulgões estavam formados e prontos para nascer. (RÉAUMUR, 1737, p. 326)

Réaumur repetiu as observações para garantir o estabelecimento da viviparidade nos pulgões. Esse compromisso de Réaumur com a regra metodológica da repetição da observação e 
experimento exemplifica uma das dimensões da Ciência Integral discutida por Allchin, a observacional. Assim, o episódio permite explicitar aspectos metacientíficos da investigação, envolvendo "replicação e tamanho da amostra", "papel do estudo sistemático" e "completude de evidências", relacionados, respectivamente, às esferas das "observações e medidas" e "experimentos" (ALLCHIN, 2013, p. 24).

A viviparidade não fornecia, contudo, nenhuma pista sobre o sexo desses indivíduos. Mesmo tento observado o nascimento de várias gerações de espécies diferentes de pulgões alados, ele não ousou decidir sobre o sexo desses insetos:

Até aqui, nós encontramos apenas fêmeas entre os pulgões, nunca encontramos insetos os quais pudéssemos considerar como machos; seriam, então, os dois sexos reunidos nesses organismos, como ocorre em caramujos? Parece que isso ainda não é suficiente, pois, vemos o acasalamento em caramujos; e sempre que eu observei os pulgões, tanto alados quanto os não alados, eu nunca percebi qualquer acasalamento [...]. O que é certo é que, se eles [pulgões alados] acasalam, é em boa hora, e o tempo do acasalamento seria, pelo menos, uma singularidade na história natural; [pois] os alados acasalam antes da última transformação [muda ou ecdise], por assim dizer, em sua infância. (RÉAUMUR, 1737, p. 327)

Essa dúvida continuou a inquietar Réaumur e o levou a pensar que talvez a reprodução dos pulgões fosse um caso excepcional.

\section{Exceção à regra?}

Para averiguar se o pulgão seria uma exceção à regra da geração animal, Réaumur elaborou um procedimento novo para 
a época, que ele chamou de "sequestração" e consistia em observar um organismo isolado de outros organismos. Ele esperou um pulgão dar à luz a um filhote e o isolou no momento seguinte ao seu nascimento - desse modo, garantia que o rebento não tivesse contato com qualquer outro indivíduo de sua espécie. Assim ele descreveu o método que ele desenvolveu:

Em um grande recipiente de vidro, eu plantei um repolho jovem, que não tinha ainda mais do que duas ou três folhas nascidas: sobre uma das folhas desse repolho eu coloquei uma mãe pulgão que eu tinha retirado de um grande pé de repolho; assim que ela deu à luz a um pequeno [filhote], eu removi a mãe de cima do repolho; cobri o recipiente com uma gaze fina de modo que o repolho jovem e o pulgão recém-nascido não fossem privados de ar e que fosse impossível a qualquer outro pulgão entrar no recipiente. (RÉAUMUR, 1737, p. 329)

Apesar dos cuidados, o filhote não se desenvolveu até a idade reprodutiva. Réaumur repetiu essa experiência quatro ou cinco vezes, e o filhote que sobreviveu por mais tempo chegou ao nono dia, enquanto outros pereceram no terceiro ou quarto dia. Os insucessos levaram Réaumur a abandonar a questão, mas, como era de seu costume, ele propôs o desafio a quem desejasse investir: "Eu tentei essa experiência várias vezes, mas ela não foi bem-sucedida. Porém relato o que eu fiz, porque as mesmas tentativas podem ser feitas por outros com mais sucesso" (RÉAUMUR, 1737, p. 329).

\section{Charles Bonnet e o enigma dos pulgões}

Passados três anos desde que iniciou as observações com insetos, Bonnet, então estudante de Direito, se dedicava 
também à leitura do terceiro volume das Memoires de Réaumur. Ao se deparar com o problema da reprodução dos pulgões, decidiu investigar pessoalmente a questão: "Animado pelo convite de Sr. Réaumur, em 1740 eu comecei a tentar essa experiência com o pulgão do carvão"4 (BONNET, 1745, p. 29).

A atitude de Bonnet, mesmo ocupado com o seu curso de Direito, é oportuna de ser realçada por indicar uma das esferas da dimensão "conceitual" da Ciência Integral de Allchin (2013, p. 24). Entre elas, o "espectro de motivações para fazer ciência", fruto de sua intensa busca pelo conhecimento e admiração pela história dos insetos.

Decidido então a refazer o estudo de Réaumur, Bonnet iniciou a experiência com esse pulgão, em Genebra, às 5 horas da tarde do dia 20 de maio de 1740. Após ter imaginado um meio seguro de manter o organismo isolado, assim descreveu e ilustrou (Figura 2) o procedimento adotado:

Em um vaso de flores [figura 1], preenchido com terra comum, eu enterrei, até o seu gargalo, uma garrafa de vidro [figura 2] cheia d'água. Eu inseri nessa garrafa um pequeno ramo de evônimo [figura 3], contendo não mais que cinco ou seis folhas, depois de examiná-las de todos os lados com a maior atenção. Em seguida, eu depositei sobre uma dessas folhas um pulgão cuja mãe, desprovida de asas, acabara de dar à luz sob meus olhos. Eu cobri o pequeno ramo com um pote de vidro [figura 4], cujas bordas encostavam perfeitamente sobre a superfície da terra do vaso

\footnotetext{
${ }^{4}$ Pulgão do carvão (Aphis fabae) ou pulgão negro da fava é conhecido por sua coloração escura. Até hoje ele é considerado como o hospedeiro principal do evônimo (Evonymus europaeus) ou fusain, em francês (BLACKMAN; EASTOP, 2007, p. 9).
} 
de flores, certo de que o estava conduzindo como Danae, presa numa torre de marfim por ordem de Acrísio $^{5}$. (BONNET, 1745, p. 27)
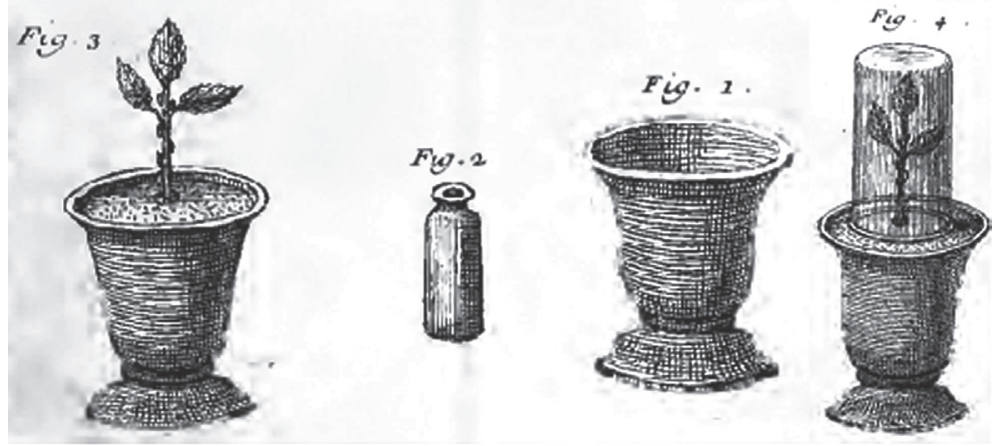

Figura 2 - Ilustração do procedimento utilizado por Bonnet para manter o pulgão isolado. Note-se que, embora numeradas, as figuras não são ordenadas segundo o padrão atual, da esquerda para a direita.

Fonte: Bonnet (1745, prancha 4, p. 293).

Bonnet registrou diariamente as observações feitas de hora em hora e em intervalos menores, começando às quatro ou cinco da manhã e findando às nove ou dez horas da noite (BONNET, 1745, p. 28). Naquele momento, ele concentrou inteiramente a sua atenção no pequeno inseto. Enquanto os pulgões que Réaumur havia observado não avançaram além da segunda troca de pele, perecendo pouco tempo depois, Bonnet (1745, p. 31) observou o seu pulgão alcançar a maturidade depois de quatro trocas de pele, "um trabalho aparentemente penoso".

\footnotetext{
${ }^{5}$ A metáfora citada por Bonnet refere-se ao mito grego do rei Acrísio, que, desapontado por não ter filhos homens que o sucedessem no trono, decidiu pedir ajuda a um oráculo. A resposta recebida foi que um neto iria matá-lo. Assim, para evitar que sua filha, Danae, tivesse filhos, Acrísio a trancou isolada em uma torre.
} 
O mérito de Bonnet, que adaptou o dispositivo de isolamento do organismo idealizado por Réaumur, foi o de ter obtido êxito nessa criação artificial de pulgões, o que certamente representa superação de dificuldades técnicas que o naturalista francês não havia conseguido resolver (SIGRIST, 2001, p. 427). Bonnet exerceu longos e contínuos períodos de observação do pulgão, produzindo um registro diário do comportamento de seu objeto de estudo. Nota-se que a preocupação dada à "acurácia" e "precisão" nas observações refletem outro aspecto da dimensão observacional do fazer científico (ALLCHIN, 2013, p. 24).

O que vem a seguir é o que Bonnet chamou de "os fatos mais interessantes da vida de nosso solitário", o pulgão (BONNET, 1745, p. 38).

\section{A multiplicação sem acasalamento}

Estabelecida a eficiência do procedimento de isolamento do organismo, e garantida simultaneamente a sua sobrevivência, Bonnet passou então a investigar se esses insetos seriam "suficientes a si mesmos" (BONNET, 1745, p. 116). Após uma longa vigília de observações, no dia 10 de junho de 1740 a sua paciência e dedicação foram recompensadas:

Cerca de sete horas da manhã, com grande contentamento, eu vi o nascimento; e desde logo eu julguei que devia chamá-lo de pulgãozinho. A partir desse dia, e durante os 21 dias seguintes, nasceram 95 filhotes, todos bem vivos e a maior parte nascendo diante dos meus olhos. Eis uma Tabela [figura 3] em que assinalei com a maior exatidão que me foi possível o dia e hora do nascimento de cada um desses pulgões. $\mathrm{O}$ asterisco indica os nascimentos que ocorreram 
em momentos em que eu não estava observando. (BONNET, 1745, p. 39)

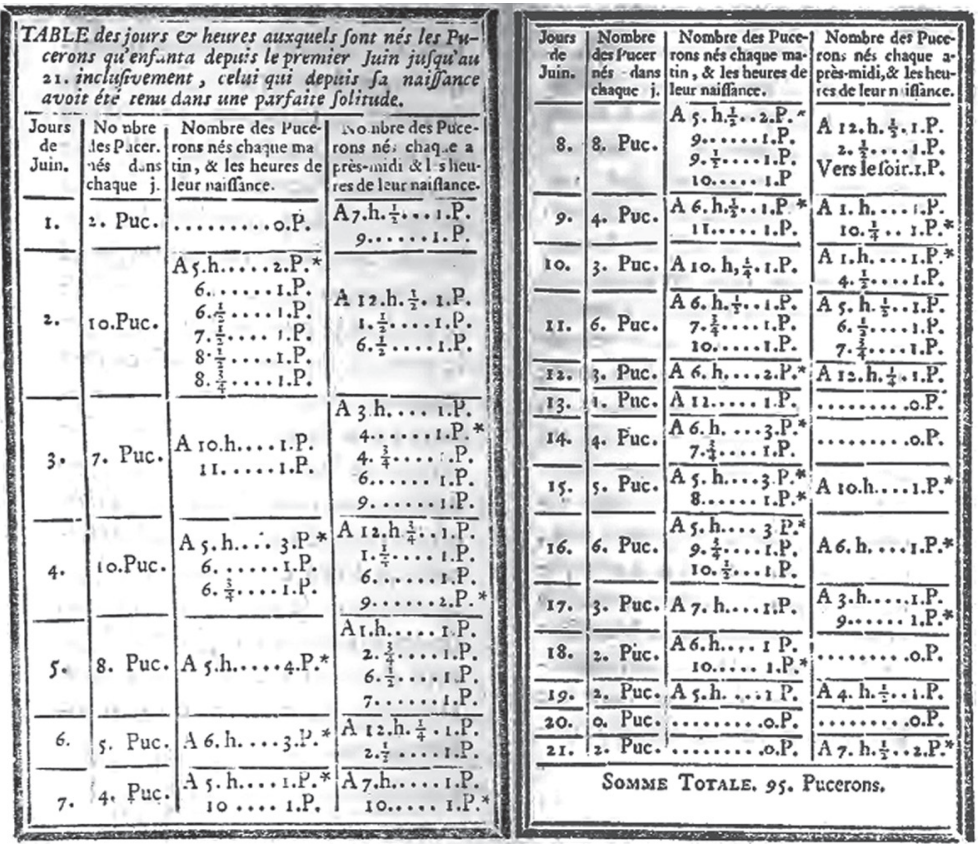

Figura 3 - Registro de nascimento dos pulgões. Da esquerda para a direita, as colunas representam dia de nascimento, quantidade, número de pulgões e hora de nascimento antes do meio-dia e após o meio-dia, respectivamente.

Fonte: Bonnet (1745, p. 40).

Além da preocupação de produzir uma narrativa detaIhada das suas observações, Bonnet (1745) também apresentou um cuidado particular ao organizar alguns dados obtidos na forma de tabelas. Essa prudência metodológica, que estava sendo estabelecida pelos naturalistas observadores e experimentadores do século XVIII, se configura como uma dimensão sociocultural da ciência que pode ser discutida com os estudantes, 
enfatizando o papel da "comunicação" com respeito às "normas para o manuseio de dados científicos" (ALLCHIN, 2013, p. 24).

A estratégia de registro diários das investigações adotada por Bonnet, desenvolvendo ilustrações com legendas e tabelas, facilitava tanto a reunião de informações quanto a redução de palavras - uma indicação de que a prática da condução de observações e experimentos em série demandava uma abordagem econômica de escrita científica. Essa nova forma de apresentação de dados era um método muito menos prolixo na apresentação de informações, que se generalizou na segunda metade do século XVIII (RATCLIFF, 2004, p. 569-571).

Bonnet foi capaz de lograr êxito ao concluir uma experiência que outros naturalistas fracassaram. Entusiasmado pela descoberta, ele decidiu reportar os detalhes das observações a Réaumur. O naturalista da Academia de Ciências de Paris não deixou de reconhecer a contribuição de Bonnet e de sugerir ainda novas observações:

Seguro da satisfação que as observações do Sr. Bonnet fariam à Academia [de Ciências de Paris], logo comecei a ler a sua carta datada de 13 de julho [1740] em que estavam os detalhes [das observações]. Ficou aparente para toda a Academia que o Sr. Bonnet tinha tomado as precauções e cuidados [...], no entanto, ele detinha apenas uma experiência, que embora muito bem-feita, não era suficiente para evitar dúvidas em relação a um ato contrário a uma lei geral que parecia estabelecida pelo apoio unânime dos fatos até então vistos. Temos muitos exemplos de circunstâncias que escaparam aos olhos perspicazes e atentos. A Academia, portanto, não poderia deixar de desejar que o mesmo experimento fosse repetido pelo Sr. Bonnet, muitas vezes, e com as mais diferentes espécies de pulgões que fosse possível. (RÉAUMUR, 1742, p. 537) 
A excepcionalidade do evento levou Réaumur (1742, p. 29) a divulgar a descoberta a outros três "excelentes observadores", para que repetissem a experiência: o francês Gilles-Augustin Bazin (1681-1754); o genebrês (e primo de Bonnet) Abraham Trembley (1710-1784) e o holandês Pierre Lyonnet (1708-1789) - "um dos mais perspicazes observadores de insetos" (RÉAUMUR, 1742, p. 538). Os três naturalistas se empenharam em repetir as observações de Bonnet a fim de certificar a sua veracidade. Usando métodos diferentes de isolamento e espécies diversas, todos confirmaram a mesma conclusão: pulgões são gerados sem a necessidade de qualquer cópula.

Por se tratar de caso singular, o evento da reprodução dos pulgões necessitou de mais evidências produzidas por outros "especialistas". Nesse ponto, é importante ressaltar a dimensão sociocultural, relacionada aos aspectos das "instituições" e da relevância da "revisão por pares" (ALLCHIN, 2013, p. 24), a fim de corroborar aquilo que seria uma exceção à regra da reprodução animal. Ademais, para essa "validação por pares", o próprio Bonnet sabia que a repetição dependia de um relato minucioso dos métodos empregados:

Nós vivemos em um século em que as Observações, sobretudo aquelas que são objetos de fatos singulares, precisam ser detalhadas, e até certo ponto, repetidas várias vezes. Não queremos saber apenas os resultados das Observações ou Experiências. Queremos saber como o Observador chegou à descoberta que ele relata. As particularidades [recursos] que estão disponíveis no percurso e os obstáculos que ele encontrou. (BONNET, 1745, p. 51)

No outono de 1740, enquanto Bonnet repetia e conduzia novas observações com outras espécies de pulgões, um fato 
inusitado chamou a sua atenção. Ele constatou que uma dessas espécies era capaz de acasalar! Fato concomitantemente observado por Lyonnet e Trembley, na Holanda. A observação da cópula nessa espécie trouxe novamente a dúvida sobre a multiplicação sem acasalamento e Trembley escreveu a Bonnet conjecturando a hipótese: "Em casos distantes do ordinário, todas as tentativas são permitidas. Quem sabe se um único acasalamento não seria suficiente para várias gerações?" (TREMBLEY, 1741 apud DAWSON, 1987, p. 89; BONNET, 1745, p. 66).

Para responder a pergunta de Trembley, Bonnet realizou a sua maior série de exaustivas e contínuas observações. TrabaIhando com espécies de pulgões do sabugueiro, da banana, do carvalho e do carvão, obteve, da primeira e da terceira, cinco e depois nove gerações consecutivas de pulgões nascidos sem qualquer acasalamento. Sobre essas observações, Bonnet considerou:

Somos forçados a admitir e concordar que os pulgões perpetuam sua espécie absolutamente sem acasalamento ${ }^{6}$, ou admitir que um único acasalamento sirva, ao menos, a nove gerações consecutivas; o que seria admitir algo igualmente distante às regras ordinárias [...]. Não creiam, no entanto, que eu digo isso para me dispensar de continuar com essas experiências e estendê-las a um número maior de Gerações [...]. Eu não me desesperaria, porém, de tentar colocar em solidão, ao menos, até a trigésima geração desses pequenos insetos [...] [Entretanto] eu não observei diferenças muito sensíveis com relação ao tamanho

\footnotetext{
${ }^{6}$ Essa forma de reprodução sem acasalamento em pulgões (afídeos) é atualmente conhecida como partenogênese, termo cunhado apenas em 1849 por Richard Owen (OWEN, 1849). Todas as espécies conhecidas são ciclicamente partenogenéticas, isto é, sazonalmente alternam entre uma ou várias gerações em que os ovos não fertilizados se desenvolvem em fêmeas e uma geração sexual em que ovócitos devem ser fertilizados por um espermatozoide (DAVIS, 2012).
} 
entre os pulgões das últimas gerações e daquelas gerações precedentes [...]. A segunda coisa que eu observei é que os pulgões alados de cada Geração foram todos produzidos sem que eu os jamais visse acasalando uns com os outros ou com os não-alados [sic]. (BONNET, 1745, p. 102-103)

Para fortalecer seu argumento, Bonnet conduziu "séries de experiências" por meio de repetições e variações, a fim de garantir a estabilidade e analisar a extensão do "fato novo" (SIGRIST, 1994, p. 430). As "séries de experiências", características dos experimentadores do século XVIII, remetem ao planejamento de um conjunto de experiências ordenadas, com o objetivo de corroborar uma hipótese e validar uma teoria (RATCLIFF, 1995 apud PRESTES, 2003, p. 310).

Assim, a série experimental de Bonnet, sistematizada num conjunto de observações coordenadas, não era uma simples acumulação de eventos destinados a evidenciar os "fatos". Pode-se dizer que a série possuía uma abordagem analítica que reside em dois tipos de observações ou experimentos: (1) as experiências discriminatórias que visam validar/invalidar uma hipótese ou para estabelecer a existência de um fato, e esse é o caso da experiência da multiplicação sem acasalamento, que introduziu um fato novo e ao mesmo tempo destituiu o dogma da universalidade da reprodução sexual em animais; (2) experiências generalizantes, que têm uma função de análise, úteis para determinar a extensão de um fato, estabelecer as suas diferentes variantes, bem como atestar a sua estabilidade e reprodutibilidade em diferentes lugares e circunstâncias (SIGRIST, 1994, p. 430).

A preocupação em apresentar uma narrativa detalhada da descoberta apresentada por Bonnet se configura como uma 
retórica científica, que pretende fazer do leitor uma testemunha virtual, suscetível a repetir todas as observações e experiências. Além de apontar as minúcias dos procedimentos utilizados, ilustrar os dispositivos e precauções tomadas, ele alimenta a sua história com fragmentos importantes do seu diário de "laboratório" apresentados sob a forma de ilustrações e tabelas a fim de aumentar a fidelidade da narrativa (SIGRIST, 1994, p. 437).

\section{Considerações finais}

Ao longo deste capítulo, foi analisada a "descoberta" da multiplicação sem acasalamento em pulgões realizada por Charles Bonnet a partir de sua interlocução com naturalistas da época, especialmente o francês Réaumur. Os estudos mencionados estabeleceram que as fêmeas de várias espécies de pulgões são capazes de se reproduzir sem cópula, fenômeno denominado "partenogênese" em 1849. Esse fato gerou um impacto na época devido a contrariar a regra geral de reprodução sexuada entre os animais.

A narrativa do episódio histórico contendo a descrição e análise das observações e experimentos foi acompanhada por inserções sobre aspectos metacientíficos envolvidos, conforme as dimensões da Ciência Integral, propostas por Allchin. Considera-se que esta narrativa histórica, enriquecida pelos aspectos metacientíficos indicados, constitui-se um material didático que oferece uma abordagem explícita e reflexiva em sala de aula de ciências e biologia sobre aspectos de como a ciência funciona. Espera-se que essa possa ser uma contribuição para incrementar a alfabetização cientifica dos estudantes. 


\section{Referências}

ALLCHIN, Douglas. The Minnesota Case Study Collection: New Historical Inquiry Case Studies for Nature of Science Education. Science and Education, v. 21, n. 9, p. 1263-1281, 2012.

- Teaching the Nature of Science: Perspectives \& Resources. Saint Paul, MN: SHiPS Educational Press, 2013.

BLACKMAN, Roger L.; EASTOP, Victor F. Taxonomic Issues. In: VAN EMDEN, Helmut F.; HARRINGTON, Richard (Ed.). Aphids as Crop Pests. Cambridge, MA: CABI, 2007. p. 1-22.

BONNET, Charles. Traité d'insectologie ou Observations sur les Pucerons. Paris: Chez Durand, 1745.

- Oeuvres d'Histoire Naturelle et de Philosophie. Neuchâtel: Librarie du Roi, Chez Samuel Fauche, 1779. v. 2.

ERDURAN, Sibel; DAGHER, Zoubeida. Reconceptualizing the Nature of Science for Science. Science \& Education, v. 25, n. 1, p. 1-2, 2016.

DAVIS, Gregory K. Cyclical Parthenogenesis and Viviparity in Aphids as Evolutionary Novelties. Journal of Experimental Zoology Part B: Molecular and Developmental Evolution, v. 318, n. 6, p. 448-459, 2012.

DAWSON, Virginia P. Nature's Enigma: The Problem of the Polyp in the Letters of Bonnet, Trembley and Réaumur. Philadelphia: American Philosophical Society, 1987.

FITZGERALD, Terrence D. Role of Trail Pheromone in Foraging and Processionary Behavior of Pine Processionary Caterpillars 
Thaumetopoea pityocampa. Journal of Chemical Ecology, v. 29, n. 3, p. 513-532, 2003.

GOEDAERT, Johannes. Metamorphoses naturelles, ou, Histoire des insectes: observée tres-exactement suivant leur nature \& leur proprietez: avec les figures en taille-douce gravées d'aprés nature. Amsterdam: Chez George Gallet, 1700.

HATCH, Robert. A. Correspondence Networks. In: APPLEBAUM, Wilbur (Ed.). Encyclopedia of the scientific revolution: from Copernicus to Newton. New York: Garland Publishing, 2000. p.168-170.)

LEONI, Simona Boscani. Men of exchange: creation and circulation of knowledge in the swiss republics of the eighteenth century. In: HOLENSTEIN, André; STEINKE, Hubert; STUBER, Martin (Ed.). Scholars in action: The practice of knowledge and the figure of the savant in the 18th century. Leiden: Brill, 2013. v. $2,507-533$.

MARTINS, Lilian Al-Chueyr Pereira. A História da Ciência e o Ensino de Biologia. Ciência \& Ensino, v. 5, p. 18-21, 1998.

MARTINS, Roberto A. Introdução: A história das ciências e seus usos na educação. In: SILVA, Cibelle C. (Ed.). Estudos de história e filosofia das ciências: subsídios para aplicação no ensino. São Paulo: Livraria da Física, 2006. p. 11-34.

MATTHEWS, Michael R. Science Teaching: The Role of History and Philosophy of Science. New York: Routledge Chapman \& Hall, 1994.

MCCLELLAN, James. Scientific institutions and the organization of science. In: PORTER, Roy (Ed.). The Cambridge History of 
Science: Eighteenth-Century Science. Cambridge, UK: Cambridge University Press, 2008. p. 87-106.

METZ, Don. We now interrupt the story: mediating student learning using historical stories. In: NINTH INTERNATIONAL HISTORY, PHILOSOPHY AND SCIENCE TEACHING CONFERENCE, june 24-28 2007, Calgary, Canadá. Anais... Calgary: University of Calgary, 2007. p. 1-15. Disponível em: <https://goo.gl/j7fj7D>. Acesso em: 18 out. 2016.

OWEN, Richard. On parthenogenesis, or The successive production of procreating indivduals from a single ovum. London: J. Van Voorst, 1849.

PHILLIPS, Everett. A Review of Parthenogenesis. Proceedings of the American Philosophical Society, v. 42, n. 174, p. 275-345, 1903.

PLATEAU, Félix. Études sur la parthénogenèse. Gand: C. AnnootBraeckman, 1868.

PRESTES, Maria Elice B. A biologia experimental de Lazzaro Spallanzani (1729-1799). 2003. 393 f. Tese (Doutorado em Educação) - Faculdade de Educação, Universidade de São Paulo, São Paulo, 2003.

. Definição e classificação de insetos por René-Antoine Ferchault de Réaumur. Filosofia e História da Biologia, v. 3, n. 1, p. 263-284, 2008.

PRESTES, Maria Elice Brzezinski; MARTINS, Lilian Al-Chueyr Pereira. Observação e Experimentação Animal no Século XVIII: os estudos de Abraham Trembley sobre a hidra. Acta Scientiae, v. 16, n. 2 , p. 345-369, 2014. 
RATCLIFF, Marc. Abraham Trembley's strategy of generosity and the scope of celebrity in the mid-eighteenth century. Isis, v. 95, n. 4, p. 555-575, 2004.

- Experimentation, communication and patronage: a perspective on René-Antoine Ferchault de Réaumur (16831757). Biology of the cell, v. 97, n. 4, p. 231-233, abr. 2005.

RÉAUMUR, René Antoine Ferchault de. Memoires pour servir a I'histoire des insectes. Paris: L'imprimerie royale, 1734. v. 1. Paris: L'imprimerie royale, 1736. v. 2. . Paris: L'imprimerie royale, 1737. v. 3. . Paris: L'imprimerie royale, 1742. v. 6.

RODRIGUE, Jean-Paul; COMTOIS, Claude; SLACK, Brian. The Geography of Transport Systems. 3. ed. New York: Routledge, 2013.

SIGRIST, René. L'expérimentation comme rhétorique de la preuve : L'exemple du Traité d'insectologie de Charles Bonnet. Revue d'histoire des sciences, v. 54, n. 4, p. 419-449, 2001.

TERRALL, Mary. Following insects around: tools and techniques of eighteenth-century natural history. The British journal for the history of science, v. 43, n. 4, p. 573-588, 2010. 


\section{ASPECTOS DA NATUREZA DA CIÊNCIA \\ NAS PESQUISAS DE IRVING LANGMUIR \\ (1881-1957) RELACIONADAS COM \\ A ESTRUTURA DA MATÉRIA}

Hélio Elael Bonini Viana

\section{Introdução}

A importância de abordagem histórica da ciência em sala já foi discutida por inúmeros autores - por exemplo, Matthews (1995) e Forato (2009) -, podendo, entre outras benesses, fomentar o pensamento crítico por meio de humanização das ciências e de aulas mais desafiadoras e reflexivas. Todavia, é um equívoco considerar que abordagens focadas na história da ciência resolveriam todos os problemas do ensino de ciências. Aliás, é importante atentar que a veiculação da história da ciência pode resultar em diversos problemas, tais como: erros factuais grosseiros, relações não contempladas entre o processo de produção de conhecimentos na Ciência e o contexto, glorificação do presente e dos seus paradigmas, estímulo da ideia dos conhecimentos científicos como verdades absolutas e entendimento do "progresso" científico como o resultado de descobertas 
realizadas por cientistas geniais. Tal abordagem pode resultar em "[...] uma visão rígida, algorítmica, exata da ciência, reforçado uma interpretação acumulativa, linear do desenvolvimento científico, ignorando crises e revoluções científicas" (BASTOS, 1998, p. 43). Segundo Forato, Martins e Pietrocola (2011), uma das formas para não incorrer nesse tipo de problemas seria a utilização de estudos de casos históricos, os quais poderiam desenvolver a complexa relação entre ciência, tecnologia e sociedade.

De acordo com Porto (2010, p. 174), um estudo de caso histórico pode ser definido como "[...] a análise, com certa profundidade, de algum episódio histórico bem delimitado da História da Ciência". Logo, um estudo de caso pressupõe a abordagem de problemas pertinentes a uma época que influenciaram um cientista - ou um filósofo natural -, ou seja, um relato que viabilize a discussão da natureza sistêmica da natureza científica. Tal abordagem de um estudo de caso está diretamente relacionada com a chamada "nova historiografia da ciência", a qual abarca necessariamente a contextualização das ideias, buscando significados a partir de uma "imersão" em correntes de pensamento de uma determinada época.

Além da sua viabilidade para a elucidação de conceitos científicos, um estudo de caso também pode ser empregado para a discussão de aspectos pertinentes à natureza a ciência (ALLCHIN, 2013; SILVA; MOURA, 2008). Sem perder de vista as discussões acerca de suas vertentes (MOURA, 2014), procurou-se seguir aqui uma abordagem em consonância com a delineada por Douglas Allchin, a qual se destaca, dentre outros pontos, por apresentar estudos de caso históricos como uma atividade de ensino de natureza da ciência em de sala de aula.

Nesse contexto, optou-se pela elaboração de um estudo de caso que contemplasse aspectos da estrutura atômica a 
partir de uma problematização. Dentre as possibilidades encontradas, um estudo embasado em Irving Langmuir (1881-1957) mostrou-se promissor, pelo fato deste cientista ter realizado pesquisas variadas, mostrando interesses tanto pela área básica como pela aplicada. Uma ideia clara da diversidade dos seus interesses pode ser vislumbrada na bibliografia desse cientista americano elaborada por Rosenfeld (1966). De 1906 a 1955, seus trabalhos abordaram assuntos diversos, tais como: reações químicas a altas temperaturas e baixas pressões (1906-1921), efeitos térmicos em gases (1911-1936), estrutura atômica (19191921), emissões termiônicas e superficiais no vácuo (19131937), forças químicas nos sólidos, líquidos e na superfície de filmes (1916-1943), descargas elétricas em gases (1923-1932) e a ciência de ponta (1938-1955). Vale ainda ressaltar que, durante a Primeira Guerra Mundial (1914-1918), Langmuir se envolveu com pesquisas militares, como desenvolvimento de sonares para submarinos e na fixação de nitrogênio em explosivos.

Dessa maneira, tomando por base a maneira de trabaIhar estudos de casos históricos elaborada por Allchin (2013), foram propostas algumas questões reflexivas sobre os trabaIhos de Langmuir relacionados com a estrutura da matéria, com o propósito de orientar um docente para o ensino da natureza da ciência.

\section{As pesquisas de Irving Langmuir sobre estrutura da matéria: um estudo de caso}

Nascido no Brooklin (Nova York), no ano de 1881, Irving Langmuir, o terceiro filho de uma família cujo patriarca era um 
renomado corretor de seguros, teve parte de sua educação básica feita em Paris (1892-1895). Seu irmão, Arthur Langmuir, químico industrial de destaque, foi o seu grande mentor científico em sua infância, despertando-lhe o interesse pela Ciência e por suas aplicações. Como consequência disso, acabou se graduando em Engenharia Metalúrgica pela Universidade de Columbia em 1903. Disposto a prosseguir seus estudos, Langmuir realizou seu doutorado na Universidade de Göttinger (Alemanha), em 1906, sob a orientação de físico-químico Walther Nerst, estudando a dissociação de gases a baixa pressão e alta temperatura.

Voltando aos Estados Unidos, Langmuir começou sua carreira na General Electric Company em 1909, buscando investigar por que as lâmpadas de filamento de tungsténio queimam em um curto espaço de tempo (ROSENFELD, 1966). Enquanto trabalhava para resolver este problema, testando vários gases em um ambiente de baixa pressão - gases inertes como o nitrogênio e argônio foram os que apresentaram os melhores resultados -, outros projetos de investigação emergiram do tratamento desses dados (TAYLOR, 1958). Entre esses projetos está uma proposta para a explicação da estrutura atômica e molecular.

Em setembro de 1916, cerca de três anos antes de iniciar suas publicações sobre a estrutura atômica, Langmuir mostrou entusiasmo por uma apresentação feita por W. H. Bragg, afirmando que "[...] as estruturas dos cristais estudados pelos Braggs nos levam a concepções mais definitivas quanto à natureza da química" (LANGMUIR, 1916, p. 2221). Além dos fenômenos de adsorção e tensão superficial, cujas pesquisas viriam a ter um grande impacto dentro da comunidade científica, o trabalho sobre o uso de raios-x para a elucidação da estrutura cristalina também parece ter fomentado o interesse de Langmuir pelas partículas constituintes de matéria e suas interações 
(LANGMUIR, 1919c). Assim, explorando os estudos sobre o espectro eletromagnético, modelos atômicos e valências - como os de Bohr, Rydberg, Thomson, Rutherford, Kossel e Lewis (LANGMUIR, 1919b), Langmuir conseguiu, de acordo com suas próprias palavras, estender a teoria de Lewis do átomo cúbico - segundo a qual os elétrons de valência, em átomos não combinados, estariam dispostos no vértice de um cubo - propondo representações até o elemento de número atômico 64 (gadolínio-Gd) e empregando-as em uma tentativa de elucidação da estrutura de diferentes partículas, tais como as moléculas de ácidos nitro-oxigenados - Figura 1 (LANGMUIR, 1919a). Para esse empreendimento, Langmuir estabeleceu inicialmente 11 postulados que cobrem o arranjo dos elétrons em átomos isolados e sua partilha preferencial em compostos, tentando deduzir toda a estrutura da química teórica e descritiva. Sobre os seus postulados, Langmuir disse:

Estes postulados marcam o início, creio eu, de uma nova química, uma química dedutiva, na qual podemos propor relações químicas sem cair na intuição química [...]. Eu acho que dentro de poucos anos vamos ser capazes de deduzir 90 por cento de tudo o que está em cada livro sobre química, deduzi-lo como você precisa, a partir de princípios comuns simples, conhecendo fatos definitivos sobre a estrutura do átomo. (1921 apud JENSEN, 1984, p 196)

Para explicar a estabilidade dos átomos, bem como a tendência para estabelecer ligações, Langmuir veio a desenvolver, a partir de seus postulados, uma expressão matemática para a regra do octeto, que ajudou a classificar os compostos em completos (covalentes e não covalentes), incompletos (intermetálicos e sais dos elementos "pesados" - por exemplo, cloreto de crômio III, cloreto de cobre II e óxido de zinco) e casos 
excepcionais (cianeto, gás nitrogênio, boranos, entre outros). De acordo com esta regra, a soma dos elétrons de valência disponíveis ( $\Sigma e$ ) pode ser calculada pela expressão: $\Sigma e=8 \mathrm{~N}-2 \mathrm{~B}$ ( $N$ : número de átomos pesados; B: número de ligações covalentes entre os átomos mais pesados). Logo, amoníaco (NH3) tem um total de oito elétrons disponíveis, porque tem um átomo de nitrogênio $(\mathrm{N}=1)$ e apresenta apenas ligações simples entre o nitrogênio e hidrogénio $(B=0)$. De acordo com a concepção de Langmuir, os elétrons negativos estariam nos arredores de um núcleo de carga positiva, compondo assim a estrutura do átomo (LANGMUIR, 1919a; BURY, 1921). Na eletrosfera, os elétrons estariam contidos em celas de mesmo volume, que pertencem às várias camadas concêntricas de espessura igual em torno do núcleo (com a exceção da primeira camada, cada célula pode conter dois elétrons; o número de celas aumenta de acordo com as camadas, começando com duas na primeira), estando em movimento dentro dessas celas estáticas (LANGMUIR, 1919a).
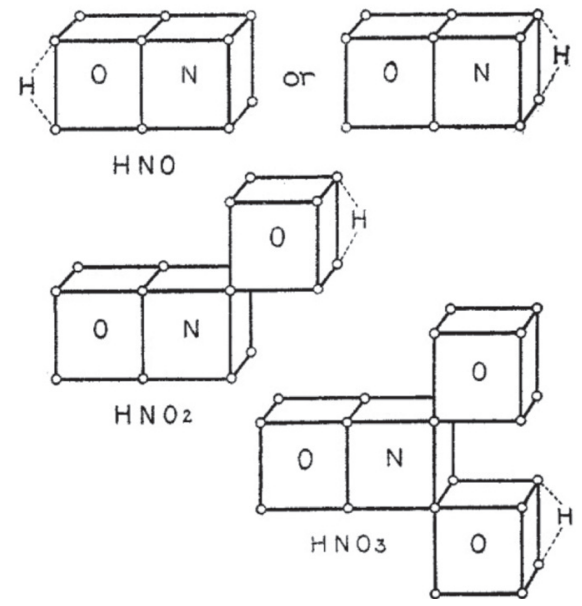

Figura 1 - Modelos de Langmuir empregando átomo cúbico para a representação das moléculas de ácidos nitro-oxigenados

Fonte: Langmuir (1919a, p. 900). 
Em 1921, diante das limitações envolvidas na determinação do número de ligações covalentes com base no número de elétrons de valência disponíveis, Langmuir reduziu seus 11 postulados em apenas três:

1) os elétrons nos átomos tendem a circular o núcleo em sucessivas camadas que contém 2,8,8,18,18 e 32 elétrons respectivamente;

2) dois átomos podem permanecer ligados por uma ou mais duplas [de elétrons] em comum para completar a camada dos dois;

3) a carga residual de cada átomo ou grupo de átomos tendem a um mínimo. (LANGMUIR, 1921 apud JENSEN, 1984, p. 197)

Mesmo tendo alcançado grande sucesso entre recursos acadêmicos e industriais, por conta da fama já alcançada por seus trabalhos, a estrutura atômica proposta com base em postulados sofreu críticas, particularmente de físicos (KOHLER JR., 1974). Sommerfeld se refere a alguns dos postulados de Langmuir como cabalísticos; já Andrade (1927, p. 112) afirma que suas representações continham muito pouco das informações já conhecidas sobre os elétrons, de tal forma que "não é imediatamente claro por que elas são chamadas de elétrons".

Além disso, em 1923, com sua aproximação do modelo dinâmico de Bohr, Lewis posicionou-se contrário à versão que Langmuir desenvolvera a partir dos seus átomos cúbicos:

A prevalência marcante de moléculas em que cada átomo tem sua cota completa de quatro pares de elétrons na camada mais externa levou Langmuir a tentar fazer a regra do octeto absoluto, e até propor uma equação aritmética para determinar, de acordo com esta regra, quando uma dada fórmula representa uma possível substância química. Acredito que o 
entusiasmo por esta ideia está conduzindo-o a um erro, e o que está sendo chamado a nova teoria, a "teoria do octeto", enfatiza demais o que é, afinal, mas uma característica da nova teoria da valência. A regra de oito[elétrons], apesar da grande importância, é menos fundamental do que a regra de dois [elétrons], o que chama a atenção para a tendência de elétrons para formar pares. (LEWIS, 1923 apud JENSEN, 1984, p. 198)

Lewis ainda deixou claro que o trabalho de Langmuir foi desenvolvido de maneira independente:

É um motivo de grande satisfação para mim descobrir que no curso da série de aplicações da nova teoria, conduzido com a maior perspicácia, Dr. Langmuir não foi obrigado a mudar a teoria que eu desenvolvia. Aqui e ali ele foi tentado a considerar certas regras ou tendências como mais universal em seu escopo do que eu considerava-os no meu papel, ou do que eu agora considero-os, mas estas são questões que terão uma oportunidade mais tarde para serem discutidas. A teoria tem sido designada por alguns como a teoria de Lewis-Langmuir, o que implicaria algum tipo de colaboração. Por uma questão de fato, o trabalho de Dr. Langmuir tem sido independente, e tais adições como ele fez com o que foi declarado ou implícito no meu papel deve ser de crédito somente a ele. (KOHLER JR., 1974, p. 60)

Apesar dessas ressalvas, o carisma de Langmuir, evidente em suas palestras e em sua boa relação com os industriais, fez com que sua interpretação sobre as ideias de Lewis - conhecida na época como a teoria Lewis-Langmuir - fosse discutida em vários países entre os anos de 1918 e 1927 (oitenta por cento dos artigos sobre o assunto foram produzidos na Grã-Bretanha, 
Alemanha e Estados Unidos). Contudo, com as rivalidades afloradas após o término da Primeira Guerra Mundial, as tendências nacionalistas tornaram-se acentuadas e resultaram em diferentes respostas para a teoria de Lewis-Langmuir: enquanto nos Estados Unidos as concepções de Lewis expressas em seu livro Valence and the Nature of Chemical Bond (1923) foram largamente divulgadas e discutidas, na Europa as discussões sobre a questão do átomo passaram a focar as contribuições de físicos como Einsten, Schrodinger, Dirac, Pauli e Heisenberg (KOHLER JR., 1975). É importante destacar que, segundo Kohler Jr. (1974), a teoria de Lewis-Langmuir possibilitou os fundamentos para o desenvolvimento da química quântica e da teoria de ressonância.

Em um artigo de 1984, Linus Pauling, ganhador do prêmio Nobel de Química em 1954 e do prêmio Nobel da Paz em 1962, destacou a importância dos trabalhos de Langmuir:

Por outro lado, os dois artigos que Irving Langmuir publicou no Jornal da Sociedade Americana de Química em 1919, num total de 84 páginas, continham várias contribuições e adições significantes à teoria da ligação química por par de elétrons compartilhados. Por alguma razão Lewis foi contra Langmuir, e em minha opinião não deu a ele o devido crédito. (PAULING, 1984, p. 201)

$\mathrm{Na}$ indústria, um sistema periódico com base na estrutura atômica de Langmuir, organizado em função do número de elétrons da camada de valência, foi empregado por Thomas Midgley Jr. para o desenvolvimento de moléculas, tais como tetraetilchumbo e os CFCs, nos Estados Unidos, na primeira metade do século XX. Neste processo, é interessante observar que Midgley, um engenheiro mecânico, na busca por substâncias requeridas pela indústria, fez uso do conceito de grupo para 
investigar possíveis átomos a integrar uma molécula (VIANA; PORTO, 2013).

Após 1921, diante do que Langmuir chamou de "excessiva abstração das discussões sobre a estrutura da matéria" fruto das contribuições oriundas da física quântica -, ele parou de se dedicar às questões do mundo atômico e passou a se dedicar a outros projetos (exemplo: o estudo da adsorção), com aplicações em curto prazo. Em 1950, aposentou-se pela General Eletric Company, passando a atuar como consultor, até o seu óbito (1957).

\section{Debatendo aspectos da natureza da ciência}

Como já foi comentado, a discussão dos aspectos da natureza da ciência no estudo de caso histórico realizado será feita com base em Allchin (2013). Especialista na interface entre história da ciência e ensino, esse autor propõe o ensino da natureza da ciência através de questões reflexivas, as quais auxiliariam a promover respostas reflexivas e articuladas, após o encorajamento do professor, mediante o diálogo entre estudantes com diferentes ideias e perspectivas (ALLCHIN, 2013, p. 177). $\mathrm{Na}$ sequência, estão elencadas algumas questões reflexivas, com os respectivos aspectos da natureza da ciência passíveis de serem ensinados.

Questão reflexiva 1: Quais os fatores que conduziram Langmuir a seus trabalhos sobre a estrutura da matéria?

Conforme relatado, Langmuir construiu sua concepção atômica e molecular partindo de um problema tecnológico evitar que as lâmpadas de tungstênio queimassem facilmente - e, posteriormente, articulando de diversas pesquisas, dentre 
elas as de Lewis e da família Bragg. A maneira como Langmuir estendeu o modelo do átomo cúbico de Lewis é, assim, um artefato da sua imaginação científica através da articulação de pesquisas científicas.

Sendo assim, com esta questão, podem ser discutidos os seguintes aspectos da natureza da ciência: o papel da imaginação científica na representação de partículas; a ciência como construção humana e a influência/colaboração entre cientistas; a abordagem experimental, instrumentos científicos e inovações tecnológicas no desenvolvimento da ciência; o papel da observação na ciência; o raciocínio analógico e o contexto cultural, econômico e tecnológico da ciência.

Questão reflexiva 2: Como explicar o fato de Langmuir ter proposto a regra do octeto?

Também por ter uma formação em engenharia, Langmuir pensava de maneira pragmática, buscando soluções "simples" para problemas tecnológicos e científicos. Dessa maneira, concatenando trabalhos de outros cientistas com a sua própria visão sobre o modus operandi da ciência, Langmuir chegou a uma expressão matemática para a regra do octeto, a qual possibilitaria entender o modo como os átomos se ligam. A partir de críticas, o arcabouço teórico que sustentava essa regra passou por adequações. Desvirtuada de sua expressão matemática e de contexto, a regra do octeto é tratada hoje como um dogma pelos livros didáticos de química, nos diferentes níveis de ensino.

Sendo assim, essa questão permite a discussão de importantes pontos da natureza da ciência como o poder heurístico da regra do octeto, o papel da indução e da dedução na ciência, se a ciência é uma verdade absoluta, mudança conceitual e as perspectivas teóricas na intepretação de dados. 
Questão reflexiva 3: Por que os trabalhos de Langmuir tiveram uma grande aceitação inicial, tanto na academia quanto na indústria?

Por trabalhar na indústria e também ter tido uma sólida formação acadêmica - Langmuir fez o seu doutorado com o renomado físico-químico alemão Walter Nerst -, Langmuir tinha circulação em diferentes meios. Além disso, Langmuir era carismático e um excelente palestrante. Logo, essa questão exemplifica outro aspecto da natureza da ciência, trazendo à tona a importância da comunicação científica dentro da ciência.

Questão reflexiva 4: Por que os méritos de Langmuir relacionados à estrutura dos materiais foram minimizados - para não dizer extirpados - em detrimento de outros cientistas?

Diante da crítica de físicos, Langmuir parou de se dedicar à estrutura da matéria após 1921. Parte dessas críticas eram movidas pelo fato de Langmuir não fazer parte de uma comunidade e por não partilhar de muitos pressupostos de uma área que estava em franca evolução no período, a física quântica. Soma-se a esse fato a influência de posturas nacionalistas - como da Alemanha e da Grã-Bretanha -, as quais foram se mostrando contrárias à teoria de Langmuir com o tempo. Desse modo, essa questão pode discutir as tradições de pesquisa, a influência do nacionalismo na ciência e o progresso não cumulativo da ciência.

Questão reflexiva 5: Por que Langmuir parou de se dedicar a estudos sobre a estrutura da matéria após 1921?

Com o aumento da complexidade - e também da abstração - das discussões sobre a estrutura das partículas, Langmuir passou a se dedicar a projetos capazes de proporcionar respostas em curto prazo, atendendo, assim, às demandas do mercado. Nesse interim, essa questão proporciona a discussão do conhecimento prático versus teórico e também do contexto cultural, econômico e tecnológico da ciência. 


\section{Considerações finais}

Os trabalhos de Langmuir, pela diversidade temática, propiciam um estudo de caso histórico com inúmeras questões pertinentes à natureza da ciência para serem discutidas em sala de aula. Neste trabalho, foram propostas algumas dessas questões, seguindo o procedimento elaborado por Allchin, capazes de promover a habilidade de pensar cientificamente, estimulando a reflexão sobre a natureza da ciência.

Como perspectiva futura, pretende-se utilizar este estudo de caso histórico, juntamente com as questões reflexivas, na formação inicial e continuada de professores. Através da colaboração dos envolvidos, as questões reflexivas poderão ser aperfeiçoadas - ou mesmo serem elaboradas novas perguntas -, para que novos aspectos da natureza da ciência possam ser discutidos.

\section{Referências}

ALLCHIN, Douglas. Teaching the Nature of Science Perspectives e Resources. Saint Paul, MN: SHiPS Education Press, 2013.

ANDRADE, Edward Neville da Costa. The Structure of the Atom. New York: Harcourt, Brace \& Co., 1927.

BASTOS, Fernando. História da ciência e pesquisa em Ensino de Ciências: breves considerações. In: NARDI, Roberto (Org.). Questões atuais no Ensino de Ciências. São Paulo: Escrituras, 1998. p. 43-52.

BURY, Charles R. Langmuir's Theory of The Arrangement of Eletrons in Atoms and Molecules, Journal of the American Chemical Society, n. 43, p. 1602-1609, 1921. 
FORATO, Thaís Cyrino de Mello. A natureza da Ciência como saber escolar: um estudo de caso a partir da história da luz. 2009. v.1 204 p. Tese (Doutorado em Educação) - Faculdade de Educação, Universidade de São Paulo, São Paulo, 2009.

FORATO, Thaís Cyrino de Mello; MARTINS, Roberto de Andrade; PIETROCOLA, Maurício. Historiografia e natureza da Ciência na sala de aula. Caderno Brasileiro de Ensino de Física, v. 28, n. 1, p. 27-59, abr. 2011.

JENSEN, William B. Abegg, Lewis, Langmuir, and the octet rule. Journal of Chemical Education, n. 61, p. 191-200, 1984.

LANGMUIR, Irving. The Constitution and Fundamental Properties of Solids and Liquids. Journal of the American Chemical Society, n. 38, p. 2221-2295, nov. 1916.

. The Arrangement of Electrons in Atoms and Molecules. Journal of the American Chemical Society, v. 41, n. 6, 868-934, jun. 1919a.

. The Structure of Atoms and the Octet Theory of Valence. Proceedings of the National Academy of Science, v. 5, n. 7, p. 252-259, jul. 1919b.

. Isomorphism, Isosterism, and Covalence. Journal of the American Chemical Society, v. 41, n. 10, p. 1543-1559, oct. 1919c.

LEWIS, Gilbert Newton. Valence and the Nature of the Chemical Bond. New York: Chemical Catalog Company, 1923.

KOHLER JR., Robert E. Irving Langmuir and the "Octet" Theory of Valence. Historical Studies in the Physical Sciences, v. 4, p. 39-87, 1974. 
. The Lewis-Langmuir Theory of Valence and the Chemical Community, 1920-1928. Historical Studies in the Physical Sciences, v. 6, p. 431-468, 1975.

MATTHEWS, Michael R. História, Filosofia e ensino de Ciências: a tendência atual de reaproximação. Caderno Catarinense de Ensino de Física, v. 12, n. 3, p. 164-214, 1995.

MOURA, Breno A. O que é a natureza da Ciência e qual a sua relação com a História e a Filosofia da Ciência? Revista Brasileira de História da Ciência, v. 7, n. 1, p. 32-46, 2014.

PAULING, Linus. G. N. Lewis and the chemical bond. Journal of Chemical Education, v. 61, n. 3, p. 201-203, 1984.

PORTO, Paulo A. História e Filosofia da Ciência no Ensino de Química: em busca dos objetivos educacionais da atualidade. In: SANTOS, Wildson Luiz Pereira dos; MALDANER, Otávio Aloísio (Org.). Ensino de Química em Foco. Ijuí: Editora Unijuí, 2010. p. 159-180.

ROSENFELD, Albert. The Quintessence of Irving Langmuir. 1. ed. New York: Pergamon Press, 1966.

SILVA, Cibelle Celestino; MOURA, Breno Arsioli. A natureza da ciência por meio de episódios históricos: o caso da popularização da óptica newtoniana. Revista Brasileira de Ensino de Física, v. 30, n. 1, p. 1602-1610, 2008.

TAYLOR, Henry. Irving Langmuir 1881-1957. London: Biographical Memoirs of Fellows of the Royal Society, 1958.

VIANA, Hélio Elael Bonini; PORTO, Paulo Alves. Thomas Midgley, Jr., and the Development of New Substances: A Case Study for Chemical Educators. Journal of Chemical Education, v. 90, n. 12, p. 1632-1638, 2013. 


\section{O CASO DA VACINA TRÍPLICE E O AUTISMO: O QUE OS ERROS NOS ENSINAM SOBRE OS ASPECTOS DA NATUREZA DA CIÊNCIA}

Renato Barboza

Simone Alves de Assis Martorano

\section{Introdução}

Pesquisas atuais têm enfatizado a importância da história e filosofia da ciência (HFC) para o ensino e aprendizagem de conceitos científicos (GIL-PÉREZ, 1993; GONZÁLEZ, 1994; CACHAPUZ; PRAIA; JORGE, 2002; NÍAZ, 2009; PORTO, 2010). A história da ciência, por exemplo, ajuda a superar as dificuldades encontradas no entendimento de conceitos científicos. Nesse sentido, Porto (2010) mostra que o estudo e discussão de episódios históricos podem propiciar aos estudantes a superação de visões inadequadas sobre a natureza do conhecimento científico, por exemplo, a ideia de que existe um único "método científico".

Embora existam importantes motivos e justificativas para a inclusão da história e filosofia da ciência no ensino, Níaz (2009) aponta que, devido à complexidade da natureza da ciência, mesmo para filósofos da ciência, algumas das controvérsias entre os pesquisadores na área de ensino de ciências estão 
centradas na questão do que deve ser incluído e em que nível de complexidade. Deve-se, portanto, levar em consideração quais ideias sobre a ciência o professor espera que seus alunos construam e, também, se está preparado para abordar esse tema em suas aulas.

Segundo Níaz (2009), apesar de controvérsias, certo grau de consenso foi alcançado dentro da comunidade de pesquisadores ${ }^{1}$. As ideias consideradas importantes e que deveriam ser incluídas no ensino são:

- O conhecimento científico baseia-se fortemente, mas não totalmente, na observação, na evidência experimental, em argumentos racionais e no ceticismo.

- As observações estão carregadas de teoria.

- A ciência é tentativa/erro.

- Não há uma maneira de fazer ciência e, portanto, não há passo a passo universal, um método científico que pode ser seguido.

- Leis e teorias possuem diferentes funções no domínio da ciência e, assim, as teorias não se tornam leis com provas adicionais.

- O progresso científico é caracterizado por uma concorrência entre teorias rivais. Diferentes cientistas podem interpretar os mesmos dados experimentais em mais de um caminho.

- O desenvolvimento de teorias científicas, às vezes, é embasado em fundamentos inconsistentes.

\footnotetext{
1 Embora essa ideia de consenso venha sendo criticada e debatida por alguns pesquisadores, pelo menos a partir de 2011 (ALLCHIN, 2013; ERDURAN; DAGHER, 2016), consideramos relevante apresentar a perspectiva de Níaz (2009), que analisou a falta de compreensão desses aspectos da natureza das ciências em pesquisas realizadas com professores.
} 
- Os cientistas são criativos e muitas vezes recorrem à imaginação e à especulação.

- As ideias científicas são afetadas por seu meio social e histórico.

Como justificativa à inclusão dessas ideias sobre a natureza da ciência no ensino, Níaz (2009) aponta que, para a maioria dos professores, em muitas partes do mundo, falta uma compreensão adequada de alguns ou de todos os diferentes aspectos sobre a natureza da ciência descritos anteriormente. Ainda, para este autor, foi surpresa verificar, em sua análise dos currículos de ciências e manuais escolares, uma forte inclinação deles para uma postura totalmente empírica e positivista.

Ao enfocar a natureza e a dinâmica da ciência, o professor estaria discutindo aspectos relativos ao campo da filosofia da ciência. Já ao abordar como o conhecimento científico é construído, ele estaria discutindo também a filosofia da ciência, mas, nesse caso, com um enfoque internalista, ou seja, estaria discutindo as metodologias de cada perspectiva filosófica. Em oposição, um enfoque externalista da construção do conhecimento científicos seria abordado por meio da história da ciência, onde seriam consideradas as influências dentro de um contexto mais amplo (social, econômico e político).

Para Praia e Cachapuz (1994), a imagem de ciência que os estudantes carregam depende, algumas vezes, do que lhes é proporcionado pelos seus professores de ciência. Assim, esses autores acham compreensível o crescente interesse da investigação educacional pelo ensino de ciência de um ponto de vista epistemológico. Segundo os autores, há atualmente evidências claras de que as concepções dos professores acerca da natureza da ciência, do conhecimento científico e do que é o método influenciam a forma de abordar um determinado conteúdo e, 
portanto, também influenciam a imagem da ciência transmitida ao aluno.

Portanto, levando em consideração essas discussões, apresentamos um episódio recente da história da ciência, visando ao aprendizado de conceitos científicos e de aspectos da natureza da ciência. Embora não seja muito usual tratar de fatos recentes na perspectiva histórica para o ensino, o episódio relacionado ao artigo publicado na revista Lancet (WAKEFIELD et al., 1998), que associava a vacina tríplice ao autismo, pode mobilizar diversos objetivos formativos no ensino de ciências. Consideramos que episódios recentes também são de grande valia em sala de aula para facilitar a aprendizagem significativa de conceitos científicos e discutir explicitamente uma concepção informada sobre a relação entre a ciência e a sociedade (ALLCHIN, 2013). Um dos aspectos positivos de se trabalhar com episódios contemporâneos é a facilidade com que podemos encontrar mais informações sobre ele. O episódio apresentado está envolvido em controvérsias atuais e pode favorecer a discussão de importantes aspectos da natureza da ciência em sala de aula, como o erro e a credibilidade científica.

\section{A construção do episódio histórico: vacina tríplice versus autismo}

Para Gil-Pérez (1993), no campo da didática de ciências, deve-se dar uma maior atenção às abordagens propostas da HFC no ensino de ciências e utilizá-las explicitamente na fundamentação de suas propostas. Contudo, segundo o autor, essa aproximação não significa fazer do aluno um pequeno cientista, 
como se refere à aprendizagem por descoberta, mas que a HFC assuma a função:

[...] de um autêntico fio condutor - mesmo que nem sempre explícito - na transformação do ensino de ciências. Um fio condutor que tem se mostrado frutífero inclusive através dos erros cometidos e que se vê reforçado tanto pelas orientações construtivistas como pelas implicações da epistemologia contemporânea no ensino. (GIL-PÉREZ, 1993, p. 11)

Portanto, a HFC não seria mais um aspecto ou outro conteúdo que o professor deveria levar em consideração em seu planejamento do ensino, mas sim ser o eixo que integra os conhecimentos científicos.

Apesar dessas orientações, têm-se observado em diferentes pesquisas que esse processo de inclusão não é algo simples de ser realizado. Muitas dificuldades são apontadas pelos professores em relação à inclusão da história da ciência $(\mathrm{HC})$ no ensino (MARTINS, 2007). As principais delas estão relacionadas à falta de conhecimento histórico específico, ao desconhecimento de fontes secundárias confiáveis, ausência de materiais adequados e estratégias pedagógicas, como também à visão inadequada desses professores sobre a natureza da ciência.

Porto (2010) aponta que uma das razões dessas dificuldades é a falta de discussões das diretrizes oficiais por parte dos professores. É importante que o professor compreenda qual visão sobre a HC que os documentos oficiais (propostas curriculares, parâmetros curriculares nacionais) orientam é adequada para o ensino e aprendizagem dos conhecimentos científicos.

Outro problema ligado à formação dos professores que Porto (2010) identifica diz respeito à questão da qualidade das fontes de informação sobre a HC. Embora atualmente o 
professor tenha acesso a diversas fontes de pesquisa, por meio de livros didáticos, revistas especializadas, internet, entre outros, o autor chama a atenção para qual história da ciência está vinculada por essas fontes, ou seja, em qual concepção historiográfica os autores desses materiais se basearam ao escrevê-los. De acordo com Forato, Martins e Pietrocola (2011, p. 35):

Qualquer narrativa da HC traz, implícita ou explicitamente, os valores, as crenças e as orientações metodológicas do seu autor. $\mathrm{O}$ relato histórico da criação de um conceito científico, ou de um debate entre teorias rivais, ou da realização de experimentos, por exemplo, carregam concepções sobre a natureza da ciência e sobre os processos da sua construção.

Portanto, faz-se necessário que o professor, ao ter acesso a materiais históricos (por exemplo, textos em livros didáticos), consiga identificar qual visão de ciência está vinculada a eles. Também é necessário que, na escolha do material, os professores problematizem a natureza da ciência dentro do episódio escolhido. Um modo de auxiliar a escolha é proposto por Allchin (2013, p. 44). De acordo com este autor, o professor pode fazer questões que o auxiliarão na definição e escolha do episódio a ser trabalhado, por exemplo: "Por que alguém deveria acreditar nisso?"; "Você consegue enxergar algum potencial viés ou erro?"; "Como você pode remediá-lo?". Também é possível fazer perguntas mais específicas, por exemplo: "Qual o efeito do erro para a saúde da população?".

Levando-se em consideração essas preocupações, acreditamos que o estudo de um determinado episódio histórico, construído a partir da orientação historiográfica atual, possa ser um material importante para o professor em sala de aula. 
A inclusão, no episódio, de debates e controvérsias pode facilitar a construção de uma visão mais crítica da ciência, mobilizando os aspectos pretendidos da natureza da ciência.

No exemplo que apresentamos, utilizamos o artigo original de Wakefield et al. (1998) e sua retratação (RETRACTION, 2010), assim como fontes secundárias que tratam diretamente do episódio, como o artigo de Lyall (2004) e a série de artigos do jornalista que denunciou o episódio, Brian Deer (2011a, 2011b, 2011c), ambos publicados no periódico científico britânico British Medical Journal. Nestes casos, há as citações e falas de pessoas diretamente envolvidas com o episódio. Também utilizamos artigos publicados pela imprensa internacional (CNN, BBC Brasil, Revista Época).

O que nos guiou para escolha do artigo - a além das qualidades citadas anteriormente de promover o debate de alguns aspectos da história e natureza da ciência - foi o fato de ser um problema atual, que atinge o cotidiano das pessoas. Além disso, a facilidade de encontrar dados de pesquisa e o grande impacto que essas discussões têm sobre a saúde da população.

\section{O episódio}

Em 1998 foi publicado na revista Lancet (WAKEFIELD et al., 1998) um artigo que associava a vacina tríplice - que protege contra sarampo, rubéola e caxumba - ao autismo. $\mathrm{O}$ artigo relatava que 12 crianças atendidas no Royal Free Hospital, localizado ao norte de Londres, apresentaram sintomas de uma nova síndrome, que relacionava autismo e a vacina tríplice.

A partir de sua publicação, o principal autor do trabaIho, o médico britânico Andrew Wakefield (1957-), usou seus 
dados para advogar contra o uso da vacina tríplice e a favor de vacinações individuais. Embora, quando publicado, tenha sido alvo de críticas por parte da comunidade científica, o trabalho teve grande repercussão na sociedade e levou ao surgimento de movimentos antivacinas que se tornaram fortes, principalmente nos Estados Unidos da América.

Após denúncias e um processo longo de investigação, o trabalho foi retratado, mesmo que 12 anos após a sua publicação (RETRACTION, 2010). As investigações mostraram que os dados foram forjados e alguns autores tinham sérios conflitos de interesse, o que levou a revista a retirar o artigo de seus arquivos. A retratação foi assinada por 10 dos 13 autores do trabaIho, e Wakefield foi um dos que não assinou. Além da retratação, a repercussão da fraude fez com que o pesquisador britânico perdesse sua licença médica. Porém, o estrago já tinha sido feito e até hoje, mesmo depois de mais de duas dezenas de trabalhos publicados mostrando que o trabalho de Wakefield é infundado, há consequências sérias à saúde pública devido a esse episódio.

$\mathrm{O}$ que se seguiu até que o trabalho fosse retratado foi uma diminuição no número de crianças vacinadas e o reaparecimento de casos de sarampo na América do Norte e Europa. O que os defensores da ideia de que a vacinação pode estar associada ao desenvolvimento de autismo não levam em conta é que outros trabalhos mostram resultados contrários. Além disso, as pessoas ignoram dados que mostram que indivíduos não protegidos contraem sarampo e podem sofrer danos neurológicos, auditivos e até mesmo ir a óbito.

Um artigo publicado na revista Science mostrou que a infecção pelo vírus do sarampo aumenta a predisposição das pessoas a outras doenças oportunistas por cerca de três anos após a infecção (MINA et al., 2015). Esse e outros exemplos 
encontrados na literatura médica levam a uma preocupação sobre o perigo de disseminação dessa doença devido a não vacinação de indivíduos dentro de uma população.

\section{A vacinação}

A vacinação é um método preventivo bem estabelecido na comunidade científica atual, que tem como princípio a manipulação da função do nosso sistema imunológico por meio da inoculação de agentes patogênicos atenuados ou de seus componentes. Em termos práticos, o objetivo da vacinação é o de produzir anticorpos específicos que protegerão o indivíduo em caso de infecção, fazendo com que não se desenvolva a doença ou que ela seja atenuada e, com isso, não traga prejuízos.

É interessante notar que a própria descrição da origem da vacinação é um episódio histórico rico para o uso da HFC no ensino. Infelizmente, a versão popular desse episódio é muito simplista, e fomenta uma visão ingênua sobre a natureza da ciência. Sua origem é comumente associada aos experimentos conduzidos por Edward Jenner (1749-1823) que demonstraram que a inoculação da varíola bovina protegia contra a varíola humana. Presente em grande número de livros textos, os experimentos realizados por Jenner contam a história de que mulheres as quais ordenhavam vacas que tinham sido infectadas por varíola bovina não contraíam varíola humana. Com base nessa observação, Jenner infectou um menino de oito anos - filho de uma empregada - com material retirado de uma pústula de uma vaca infectada. Tempos depois, ele inoculou o menino com a varíola humana e verificou que o menino não contraiu a doença. Esse episódio ficou amplamente conhecido e foi a razão da criação do termo "vacinação", cuja origem vem de vaccinius, vacca. 


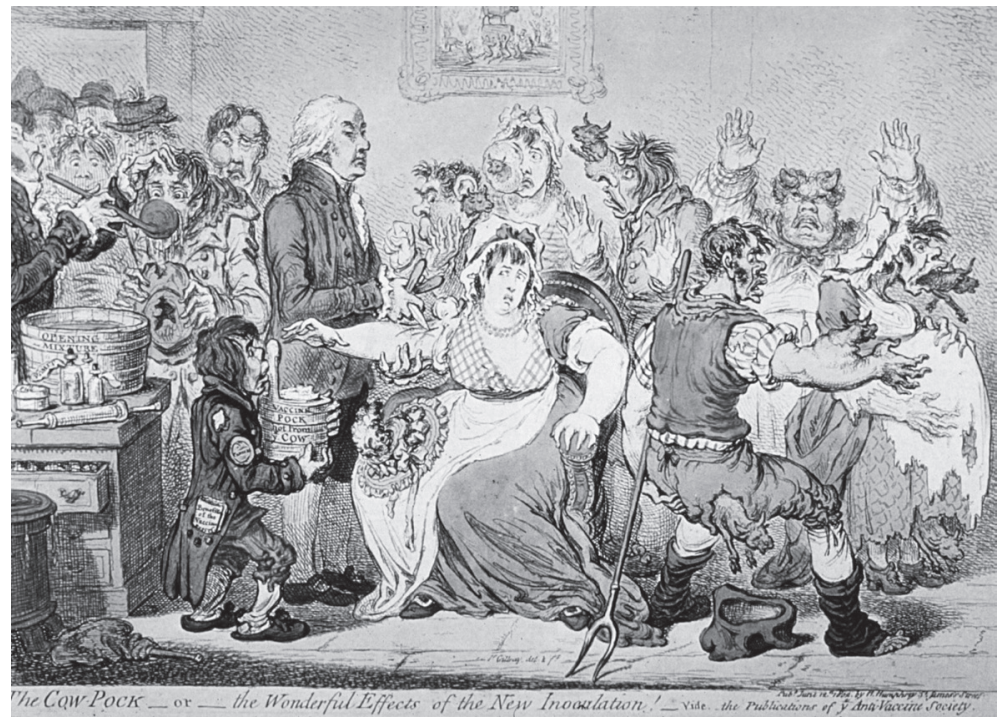

Figura 1 - Gravura de 1802, feita por James Gillray (1756-1815) mostrando as reações das pessoas à vacinação contra varíola. Embora alguns acreditem que a figura central é Edward Jenner (1749-1823) inoculando a senhora sentada, outros contestam essa afirmação. Também é possível ver partes de vacas saindo do corpo das pessoas, como referência aos oponentes à vacinação que disseminavam a ideia de que as pessoas adquiririam características das vacas.

Fonte: Wikimedia (http://www.wikimedia.org).

O que muitos livros não contam é que abordagens semeIhantes para prevenir a varíola já eram utilizadas desde o século $\mathrm{XV}$ por turcos e chineses. Antes mesmo de Jenner ter realizado seu experimento, Lady Mary Worley Montagu (1689-1762), esposa do embaixador britânico na Constantinopla, usou a técnica dos turcos em seus filhos. A técnica empregada por Lady Mary, que não era membro de uma comunidade das ciências, teve muita resistência na Inglaterra. Dentre os motivos de resistência, podemos supor a falta de credibilidade científica e o 
contexto sociocultural, uma mulher não "cientista" aplicando conhecimentos provenientes do oriente na Europa Ocidental do século XVIII (REMILLARD, 2007).

O caso que apresentamos para discussão também se relaciona com a credibilidade científica. No entanto, ao contrário do que aconteceu com Lady Mary, cuja falta de credibilidade fez com que o método usado por ela fosse amplamente contestado, no caso de Wakefield, foi justamente a credibilidade que proporcionou a ampla aceitação do seu trabalho.

Ao publicar seus resultados na respeitada revista Lancet, Wakefield, teve seu trabalho protegido pelo "manto" da ciência. A revista britânica, fundada em 1823, é reconhecida pelo seu alto impacto e por publicar trabalhos de excelência científica. $\mathrm{Na}$ época da publicação do artigo de Wakefield, a revista contava com 175 anos de experiência e reconhecimento.

Exemplo da credibilidade obtida pela publicação pode ser dado pela fala da então presidente da Autism Science Foundation e mãe de uma criança com autismo, Alison Singer, à rede de televisão estadunidense CNN em fevereiro de 2010. $\mathrm{Na}$ época, em meio a uma reportagem que expunha a retração do trabalho, Singer comentou que os motivos que levaram as pessoas a não questionarem os resultados apresentados foram devido ao fato de que "[...] a estória se tronou crível, pois foi publicada na Lancet", e complementa: "foi na Lancet, e nós confiamos nesses periódicos médicos" (PARK, 2010).

A reação de Alison é esperada na nossa cultura, em que há pouco questionamento sobre o que a ciência produz. Mas, o que perguntamos é: por que ainda há pessoas que acreditam nos resultados de Wakefield e ignoram outros que contradizem os resultados? Alguns pontos podem ser levantados para essa discussão. Um deles se deve ao fato de que o texto do artigo não é 
categórico na afirmação que realmente há uma associação entre a vacina tríplice e o desenvolvimento do autismo. Embora proposto no texto do artigo, o impacto foi realmente causado mais pela fala de Wakefield durante uma entrevista coletiva após a publicação do que pelo texto do artigo em si, como sugere Richard Horton, editor da Lancet na época da publicação (LYALL, 2004, p. 528).

Outro ponto importante é a forma como as pessoas buscam informações atualmente. Não é difícil encontrar artigos como o da BBC Brasil (2002), que alertam sobre os riscos da vacina tríplice e utilizam o artigo de Wakefield como argumento favorável ao risco. No entanto, reportagens desse tipo não fazem qualquer menção ao fato de ele ter sido retratado. De certa forma, meios de comunicação também têm ou não credibilidade e é fato que emissora britânica BBC é reconhecida pela credibilidade na informação. Nesse caso em particular, nota-se que o artigo recebeu sua última atualização em março de 2004, porém devemos lembrar que a retratação oficial só ocorreu em 2010.

Além disso, também existem crenças pessoais que são difíceis de se rebater, como o caso da porta voz do Talk About Curing Autism, Rebecca Estepp, que afirma à CNN que "[...] o $\mathrm{GMC}^{2}$ pode dizer quaisquer coisas que eles queiram pelo resto de sua existência, mas eu sei que meu filho melhorou por causa do Dr. Wakefield".

Além da credibilidade científica, outro ponto importante que pode ser trabalhado com este episódio refere-se ao fato de que a autoridade da ciência vem da sua capacidade de se autocorrigir. Porém, essa correção pode não acontecer ou, então, acontecer após um longo período. Nesse sentido, Douglas Allchin (2015, p. 20) pontua que:

${ }^{2}$ General Medical Council, organização britânica independente que ajuda a proteger os pacientes e melhorar o ensino de medicina. 
Os cientistas examinam o trabalho uns dos outros ceticamente, tentam repetir descobertas importantes e por isso expõem erros latentes. Assim, embora a ciência seja tentativa, parece também haver um sistema para corrigir quaisquer erros que apareçam. Isso explica poderosamente e justifica a autoridade da ciência. Autocorreção, portanto, serve em geral emblematicamente para promover a ciência como uma forma superior de conhecimento. Mas erros podem ocorrer e ocorrem. Alguns erros permanecem sem correção por longos períodos.

No episódio apresentado, o "erro" - leia-se fraude - foi denunciado pelo jornalista investigativo Brian Deer em 2011, um ano após a publicação da retratação (DEER, 2011a, 2011b, 2011c). Esse tempo entre publicação, denúncia e retratação foi mais que suficiente para que a informação fosse espalhada e seus efeitos observados. Ainda que pudéssemos sugerir que a presença do mecanismo de autocorreção tenha acontecido, neste caso, ela não aconteceu a contento, o que reforça a "Teoria do Mito da Autocorreção", como proposto por Allchin (2015).

\section{Considerações finais}

Neste capítulo, discutimos o episódio histórico recente sobre a relação entre a vacinação e o estabelecimento do autismo. O episódio permite trabalhar, principalmente, dois conceitos importantes sobre a natureza da ciência: o da credibilidade científica e o do mito da autocorreção, como proposto por Allchin (2015).

Ao somar a esse episódio o nosso contexto social atual, com base na busca aleatória de informação sem embasamento apropriado, mostramos a necessidade de repensarmos a 
formação de jovens durante o ensino básico, principalmente no que se refere ao ensino de história e natureza das ciências com via a formar indivíduos mais bem informados para tornar decisões baseadas em dados.

Por fim, queríamos esclarecer que, embora o trabalho de Wakefield et al. (1998) seja falho em vários aspectos, ele não deve ser usado como validação de uma teoria oposta: a de que a vacinação não traz riscos. Afinal, o método de aquisição de proteção imunológica contra agentes patógenos não é livre de riscos. Visto que, por exemplo, a vacina oral que imuniza para poliomielite, feita com o vírus atenuado, em raras ocasiões pode causar paralisia e, em outros também raros casos, choque anafilático. Porém, o risco é baixíssimo quando comparado com os benefícios da vacinação, principalmente quando analisamos a vacinação como um contrato social, ou seja, ato que necessita que cada membro da sociedade faça sua parte.

Os riscos da quebra desse contrato acontecem quando verificamos a existência de pessoas que não se vacinam no meio de um grupo vacinado. Nesse caso, observamos o surgimento de uma falsa sensação de proteção, visto que as pessoas vacinadas não transmitirão a doença para um indivíduo não vacinado. É essa falsa sensação de proteção, juntamente com os problemas apresentados neste capítulo, que levam algumas pessoas a defenderem a não vacinação e, dessa forma, a comprometerem o efeito protetor das vacinas.

\section{Referências}

ALLCHIN, Douglas, Teaching the Nature of Science: Perspectives \& Resources. Saint Paul, MN: SHiPS Educational Press, 2013. 
. Correcting the "self-correcting" mythos of Science. Filosofia e História da Biologia, v. 10, n. 1, p. 19-35, 2015.

BBC BRASIL. Cientistas alertam sobre novos riscos da vacina tríplice viral. 27 jun. 2002. Saúde \& Tecnologia. Disponível em: <http://www.bbc.com/portuguese/ciencia/020627_mmrmtc. shtml>. Acesso em: 5 jul. 2016.

CACHAPUZ, António Francisco Carrelhas; PRAIA, João Felix; JORGE, Manuela. Ciência, Educação em Ciência e Ensino das Ciências. Lisboa: Ministério da Educação, 2002.

DEER, Brian. How the case against the MMR vaccine was fixed. The British Medical Journal, v. 342, p. c5347, 2011a.

. How the vaccine crisis was meant to make money. The British Medical Journal, v. 342, p. c5258, 2011 b.

. The Lancet's two days to bury bad news. The British Medical Journal, v. 342, p. c7001, 2011c.

ERDURAN, Sibel; DAGHER, Zoubeida. Reconceptualizing the Nature of Science for Science. Science \& Education, v. 25, n. 1, p. 147-164, 2016.

FORATO, Thaís Cyrino de Mello; MARTINS, Roberto de Andrade; PIETROCOLA, Maurício. Historiografia e natureza da ciência na sala de aula. Caderno Brasileiro de Ensino de Física, v. 28, n. 1, p. 27-59, abr. 2011.

GIL-PÉREZ, Daniel. Contribución de la historia y la filosofía de las ciencias al desarrollo de um modelo de enseñanza/aprendizaje como investigación. Enseñanza de las Ciencias, v. 11, n. 2, p. 197-212, 1993. 
GONZÁLEZ, Antonio Moreno M. Historia de la ciencia: una posible contribución a la formación de los profesores. In: BLANCO NIETO, Lorenzo J.; JIMÉNES, Vicente Mellado (Coord.). La formacion del profesorado de ciencias y matematicas en España y Portugal. Badajóz: Universidad de Extremadura, 1995. p. 345-360.

LYALL, Joanna, Editor in the eye of a storm. The British Medical Journal, v. 328, n. 7438, p. 528, 2004.

MARTINS, André Ferrer Pinto. História e filosofia da ciência no ensino: há muitas pedras nesse caminho. Caderno Brasileiro de Ensino de Física, v. 24, n. 1, p. 112-131, 2007.

MINA, Michael J.; METCALF, Jéssica; SWART, Rik L. de; OSTERHAUS, Albert; GRENFELL, Bryan T. Long-term measles-induced immunomodulation increases overall childhood infectious disease mortality. Science, v. 348, n. 6235, p. 694-699, 2015.

NÍAZ, Mansoor. Progressive transitions in chemistry teachers' understanding of nature of science based on historical controversies. Science \& Education, v. 18, n. 1, p. 43-65, 2009.

PARK, Madison. Medical journal retracts study linking autism to vaccine. feb. 2010. CNN. Disponível em: <http://edition. cnn.com/2010/HEALTH/02/02/lancet.retraction.autism/index. html?hpt=T2>. Acesso em: 5 jul. 2016.

PORTO, Paulo Alves. História e Filosofia da Ciência no Ensino de Química: em busca dos objetivos educacionais da atualidade. In: SANTOS, Wildson Luiz Pereira dos; MALDANER, Otávio Aloísio (Org.). Ensino de Química em Foco. Ijuí: Editora Unijuí, 2010. p. $159-180$. 
PRAIA, João Felix; CACHAPUZ, António Francisco Carrelhas. Un análisis de las concepciones acerca de la naturaleza del conocimiento científico de los profesores portugueses de la enseñanza secundaria. Enseñanza de las Ciencias, v. 12, n. 3, p. 350-354, 1994.

REMILLARD, Erika. Lady Mary Wortley Montagu and smallpox inoculation in 18th-century England. Minneapolis, MN: SHiPS Resource Center, 2007. Disponível em: http://www. shipseducation.net/modules/biol/smallpox.htm>. Acesso em: 28 set abr. 2016.

RETRACTION - Ileal-lymphoid-nodular hyperplasia, non-specific colitis, and pervasive developmental disorder in children. The Lancet, v. 375, n. 9713, p. 445, 2010. Disponível em: http://www.thelancet.com/journals/lancet/article/PIIS01406736(10)60175-4/abstract. Acesso em: 18 out. 2016

WAKEFIELD, Andrew Jeremy; MURCH, Simon. H.; ANTHONY Andrew.; LINNELL, John.; CASSON, D. M.; MALIK, M.; BERELOWITZ, Mark.; DHILLON, A. P., THOMSON, M. A.; HARVEY, P.; VALENTINE, A.; DAVIES, S. E.; WALKER-SMITH, John A. Retracted: Ileal-lymphoid-nodular hyperplasia, nonspecific colitis, and pervasive developmental disorder in children, The Lancet, v. 351, n. 9103, p. 637-641, 1998. Disponível em: http://www.thelancet.com/journals/lancet/article/PIIS01406736(97)11096-0/fulltext. Acesso em: 18 out. 2016.

WIKIMEDIA. The cow Pock. 2016. Disponível em: <https:// upload.wikimedia.org/wikipedia/commons/thumb/d/d6/The cow_pock.jpg/800px-The_cow_pock.jpg>. Acesso em: 15 abr. 2016. 


\section{O PROCESSO CRIATIVO DE AMPÈRE NA ELABORAÇÃO DA ELETRODINÂMICA'}

Ivã Gurgel

\section{Sobre a criação nas ciências}

Como são elaborados conceitos, leis e teorias das ciências? Esta questão guarda uma complexidade grande, fazendo com que diferentes cientistas, filósofos e historiadores tenham se dedicado a ela, constituindo uma rica diversidade de posicionamentos.

Uma linha de pensamento que ganhou grande repercussão ao longo dos tempos foi a tradição que podemos denominar simplificadamente de empírico-indutivista. Ela nos remete a autores de diferentes épocas, como Francis Bacon (1561-1626), e consiste na afirmação de que, por um processo sistemático de observação de fatos, se possível controlado por experimentação, poder-se-ia obter leis gerais sobre a natureza. Assim, podemos

\footnotetext{
1 Este capítulo se baseia em parte da tese de doutorado do autor (GURGEL, 2010). Ele agradece à Profa. Christine Blondel pelo forte apoio no início de seus estudos sobre o tema. Uma das obras dela (1982) é referência importante neste texto.
} 
apontar alguns pressupostos empírico-indutivistas nos seguintes termos (ZANETIC; MOZENA, 2012):

- Há, em uma boa medida, uma objetividade nas observações realizadas e as mesmas podem ser repetidas/ reproduzidas.

- É possível estabelecer bons procedimentos que delimitem a ocorrência ou não de fatos (ou seja, é possível realizar uma experimentação devidamente controlada).

- É possível propor leis gerais a partir das observações e experimentações.

Nessa perspectiva filosófica, os conceitos e leis não seriam nada muito além de uma coleção de fatos devidamente verificados (MILL, 1843/1978). Esse posicionamento fica claro na obra do filósofo John Stuart-Mill (1806-1873). Em uma passagem de seu livro Sistema de Lógica Indutiva e Dedutiva (1843), na qual disserta sobre a proposição de Johannes Kepler (15711630), o qual afirma que as órbitas dos planetas são elípticas, o autor aponta que "[...] a elipse estava nos fatos antes que [Kepler] a reconhecesse [...]. Kepler não colocou o que concebera nos fatos, mas viu isso neles" (MILL, 1843/1978, p. 134).

A passagem anterior indica que, nas concepções empírico-indutivistas, a produção do conhecimento não exige (e até mesmo deve evitar) interpretações que envolvam um modo de olhar específico dos sujeitos. Contudo, essa filosofia passou por diferentes críticas em sua própria época e em décadas posteriores. De modo geral, ainda que objetividade, observação e experimentação controlada sejam aspectos fundamentais da ciência, buscou-se apontar que a interpretação dos fatos é, também, carregada de teoria, sendo até mesmo inseparável o dado de sua interpretação (HANSON, 1974). 
Mesmo que os posicionamentos estritamente empírico-indutivistas tenham sido criticados no âmbito filosófico, muitas pesquisas demonstram que seus pressupostos ainda são muito presentes nos contextos educacionais (GIL-PÉREZ et al., 2001). Mesmo que professores não defendam essa visão de ciência explicitamente, ela acaba estando presente em suas posturas ao buscarem ensinar ciências. Quando, por exemplo, levamos uma atividade experimental para a sala de aula e não valorizamos o trabalho investigativo e interpretativo dos alunos, estamos implicitamente considerando que "a experiência fala por si mesma".

O objetivo deste capítulo é dar uma contribuição teórica para esta questão, analisando um caso histórico: a criação da eletrodinâmica por André-Marie Ampère (1775-1836). Partindo de uma experiência realizada por Hans Christian Oersted (17771851), Ampère criou um novo arcabouço conceitual que levou muitos cientistas da época a uma reinterpretação de todo um conjunto de fenômenos elétricos e magnéticos.

Em termos atuais, a experiência de Oersted consiste no alinhamento de uma agulha imantada (como a de uma bússola) com o campo magnético produzido pela corrente elétrica gerada em um fio condutor. A partir dela, houve a unificação da eletricidade com o magnetismo, áreas que ainda se encontravam independentes. Na próxima seção do texto, será feito um resgate do trabalho de Oersted e de alguns de seus antecedentes para, em seguida, constituir uma narrativa sobre a obra de Ampère.

\section{Alguns antecedentes à eletrodinâmica de Ampère}

Os efeitos de atração e repulsão característicos da eletricidade e do magnetismo são conhecidos desde a Antiguidade. 
Deste período até a metade do século XVIII, uma grande quantidade de conhecimento foi adquirida sobre esses fenômenos, mas o saber era tratado de forma bastante dispersa, não constituindo com clareza uma unidade de análise (BLONDEL, 1982).

Um pensador que contribuiu para os estudos sobre a eletricidade e o magnetismo foi Benjamin Franklin (1706-1790) (AUDOUZE, 2006). Seu trabalho experimental se tornou bastante conhecido, principalmente por ter estudado a natureza dos raios que ocorrem durante as tempestades como fenômenos de descargas elétricas e pelas experiências com descargas elétricas produzidas por garrafas de Leyden. No entanto, para a finalidade deste trabalho, interessa verificar como ele interpreta a relação entre eletricidade e magnetismo.

Por volta de 1750, Franklin realiza uma série de experiências e, em seus relatos, descreve a imantação de agulhas através de descargas elétricas, o que indicava uma associação entre eletricidade e magnetismo (MARTINS, 1986). Contudo, como os mesmos efeitos poderiam ser produzidos por outros processos, associados ao aquecimento da agulha, Franklin é levado a considerar que as descargas elétricas são apenas auxiliares no processo de imantação. Anos depois, em uma carta, ele declara: "Em relação ao magnetismo, que parece ser produzido pela eletricidade, minha opinião real é que esses dois poderes da natureza não possuem afinidade mútua, e que a aparente produção do magnetismo é puramente acidental" (FRANKLIN, 1773 apud MARTINS, 1986, p. 7).

A posição de Franklin pode ser considerada como bastante representativa para seu período histórico e para algumas décadas subsequentes. Podemos afirmar que, naquela época, muitos filósofos naturais acreditavam em uma relação entre eletricidade e magnetismo, mas a falta de base tanto teórica quanto 
empírica para a compreensão desta relação fazia com que ela fosse descartada.

A natureza dos fenômenos elétricos e magnéticos muitas vezes se apresenta de modo muito díspar. Por exemplo, enquanto a atração e repulsão de ímãs são, em geral, fenômenos de baixa intensidade e que perduram no tempo, as descargas elétricas são o oposto, algo muito localizado no tempo e de uma intensidade até mesmo violenta. René Haüy (1743-1822), em seu Traite Élémentaire de Physique (Tratado Elementar de Física), apresenta bem essa distinção, afirmando que "[...] a eletricidade se manifesta aos olhos por jatos de luz, por faíscas estridentes, o magnetismo age passivamente e em silêncio" (HAÜY, $1821 / 1855$, p. 125 , tradução nossa).

Isso faz com que nas primeiras pesquisas com pilhas, os fenômenos que os filósofos naturais buscavam observar, fossem da mesma natureza que as descargas elétricas. Assim, em 1820, quando Oersted realiza sua experiência, buscar um efeito contínuo da eletricidade em um condutor e associá-lo ao magnetismo não eram hipóteses evidentes.

O dinamarquês Hans Christian Oersted obteve uma sólida formação em ciências e filosofia. Inserindo-se dentro da Naturphilosophie germânica. Oersted irá acreditar em uma unidade natural, em que todas as manifestações físicas (térmicas, elétricas, magnéticas, óticas) deveriam ser explicadas por um mesmo princípio. Ele mesmo declara, em um artigo da Enciclopédia de Edimburgo, que foram razões filosóficas que o guiaram à sua descoberta do eletromagnetismo (MARTINS, 1986).

Nos primeiros anos do século XIX, isto é, logo após a invenção da pilha por Alessandro Volta (1745-1827), Oersted começa a fazer suas primeiras experiências com pilhas. No entanto, é somente no inverno de 1819-1820 que Oersted realiza 
sua descoberta. Nesse momento, ele ministra um curso na Universidade de Copenhagen em que discutia suas ideias sobre a unidade das forças da natureza. De acordo com sua declaração, ele afirma que também realizava pesquisas buscando verificar os efeitos de um circuito fechado sobre uma agulha imantada. No entanto, foi durante uma aula que ministrava na Universidade de Copenhagen que ele pôde verificar que, caso a agulha fosse colocada paralelamente ao fio condutor, esta era desviada, formando um ângulo de inclinação em relação à direção do mesmo fio. Após essa primeira descoberta, Oersted busca fazer experiências detalhadas nas quais tem por objetivo compreender a natureza dessa interação. Em julho de 1820, escreve um artigo intitulado Experimenta Circa Effectum Conflitus Electrici in acum Magneticam (Sobre o Experimento do Efeito do Conflito Elétrico sobre a Agulha Magnética), em que apresenta suas experiências e procura explicar suas causas.

Oersted é um adepto de uma das interpretações vigentes em sua época e considera a existência de dois tipos de fluídos elétricos, um positivo e outro negativo. Ele julga que, quando o fio é ligado à pilha, ocorre o movimento de ambos os fluídos internamente ao fio. Devido à carga que cada um porta, os fluídos devem realizar, no fio condutor, trajetórias em sentidos contrários. Esse encontro provoca a interação entre ambos, o que Oersted chama de conflito elétrico, e dá aos fluídos um movimento de rotação (como um redemoinho). Além disso, o autor postula que este conflito não se limitará à região interna ao fio, mas que se estenderá à região de seu entorno. Em seu texto original, após uma exposição detalhada dos efeitos provocados em uma agulha em diferentes pontos do espaço ao redor do fio, o autor conclui: 
Examinemos brevemente qual é, após todos esses fatos, a ideia que nós podemos fazer do fenômeno. O conflito elétrico só age sobre as partículas magnéticas da matéria. Todos os corpos não magnéticos são permeáveis ao conflito elétrico, mas os corpos magnéticos, ou, para melhor dizer, as partículas magnéticas desses corpos, opõem uma resistência à passagem desse conflito, de maneira a acabarem levadas no choque das ações contrárias.

Parece, após os fatos expostos, que o conflito elétrico não é circunscrito ao fio condutor, mas que ele tem ao torno dele uma esfera de atividade que se estende muito. (OERSTED, 1820/1986, p. 118)

Podemos dar destaque a um conjunto de elementos presentes no processo criativo de Oersted. Primeiramente, vale lembrar, suas motivações iniciais vinham de uma visão filosófica de mundo e pouco dependiam de fatos mais evidentes. Pelo contrário, caso tivesse se limitado às experiências mais conhecidas, dificilmente teria chegado à experiência que leva seu nome. Outro ponto interessante de notar é que a experiência traz um padrão de comportamento empírico bastante novo. Neste momento, não se espera uma interação que indicasse uma "dinâmica circular" ao redor do fio. Para explicar a mesma, Oersted retoma a ideia de vórtices, que nos remete a autores mecanicistas, trazendo uma interpretação criativa aos fenômenos observados.

O texto de Oersted se popularizou relativamente rápido para os padrões da Europa do século XIX. Contudo, poucos pensadores adotaram sua interpretação para o fenômeno observado. Filósofos naturais e posteriormente os cientistas que se dedicavam a assuntos da mesma natureza, como Jöns Jacob Berzelius (1779-1848), Johann Joseph Ritter von Prechtl (17781854) e William Hyde Wollaston (1766-1828), tenderam a interpretar o fenômeno como uma magnetização do fio condutor, 
visto que o mesmo passaria a admitir polos magnéticos ao longo de seu comprimento.

Outra interpretação será constituída nos trabalhos de Ampère. Na próxima seção, será exposto com mais detalhamento seu processo criativo.

\section{Ampère e a criação da eletrodinâmica}

André-Marie Ampère adquire, desde sua juventude, uma sólida formação, mesmo não tendo seguido os meios formais de instrução. Nesse período, ele tem contato com obras como a Mécanique, de Lagrange, e a Encyplopédie, de Diderot e d'Alembert, que representam bem o conhecimento adquirido em sua época (LOCQUENEUX, 2008). Além da formação científica, Ampère se interessa profundamente por diversas áreas, passando pela filosofia e as letras. Em 1797, ele deixa sua pequena cidade natal e parte a Lyon, onde estabelece contato com intelectuais da região e estuda, em particular, a obra de Lavoisier (HOFMANN, 1995). Nesse momento, ele inicia mais profundamente suas reflexões filosóficas e funda uma sociedade com amigos, na qual se discute questões metafísicas. Como Oersted, é influenciado pela corrente germânica que considera a existência de uma unidade na natureza (BLONDEL, 1982).

Em 1800, é eleito para a academia de ciências de Lyon, assistindo lá, no ano seguinte, uma apresentação feita por Volta sobre sua pilha. Nessa mesma sessão, Ampère começa a leitura de um mémoire ${ }^{2}$ sobre eletricidade e magnetismo, mas a leitura

\footnotetext{
2 Um mémoire consiste em um manuscrito submetido à academia para ser lido em uma de suas seções.
} 
desse manuscrito nunca acabou. O que nos resta é a introdução escrita por ele, que traz elementos importantes das primeiras etapas de seu pensamento sobre estes fenômenos.

Inicialmente, Ampère relata que grandes descobertas, como as feitas por Newton, têm a característica de explicar uma gama grande de fenômenos, muitos deles que não seriam esperados inicialmente. Após essa breve ressalva, ele irá considerar:

Eu pude me lisonjear que o acaso me havia favorecido de uma dessas ideias que abrem aos físicos uma carreira nova, logo após ter reduzido todos os fenômenos do ímã e da eletricidade a um princípio único, eu vi nascer desses princípios as explicações as mais simples e as mais naturais de um grande número de fatos cujas causas ainda eram ignoradas. (AMPÈRE,1801/1982, p. 1, tradução nossa)

Com isso, ele anuncia seu projeto de unificação entre eletricidade e magnetismo, que difere completamente do seu trabalho posterior. No entanto, é interessante notar que, desde suas primeiras pesquisas, o autor era guiado por uma perspectiva que buscava estabelecer essa unificação.

Talvez o elemento mais curioso apresentado neste manuscrito inacabado seja a negação da ação à distância para os efeitos elétricos, concepção vigente na época devido aos trabalhos com a Lei de Coulomb. Ampère irá considerar que não é por "estarmos habituados", após Newton, a compreender as interações a partir de forças que atuam à distância, que essa consideração deveria ser levada para todos os fenômenos. Para ele, deve existir uma interação que seja explicada pelas próprias características dos fluídos, e com isso ela deve ser contígua no espaço. Como conclusão às suas afirmações preliminares ele estabelece: 
1 - Nós só devemos atribuir aos fluidos elétricos e magnéticos as propriedades observadas em outros fluidos, como a elasticidade comum a todos os gases e a propriedade de aderir aos outros corpos, que nós observamos na maior parte dos líquidos.

2 - Nós não devemos supor nenhuma ação entre os mesmos e os corpos que eles não tocam ou as porções de fluido homogêneo que não lhe são contíguas, a não ser que seja produzido por uma reação do fluido espalhado no espaço intermediário, de onde se segue que nós devemos nos ocupar unicamente da ação de cada molécula de matéria sobre aquelas que estão imediatamente no mesmo ambiente. E como não há ponto de vazio real em torno de nosso globo, essa ação se propagando de ponto a ponto é suficiente para explicar, assim como nós veremos, todos os fenômenos que fazem parte dessa teoria a qual nós poderemos fazer, no futuro, um ramo da mecânica como nós fizemos com a hidrostática, mesmo que esta última ciência tenha sido durante muito tempo uma teoria experimental. (AMPÈRE, 1801/1982, p. 1, tradução nossa)

Considerando que os fluídos têm propriedades próprias que nos permitem explicar a interação entre dois corpos, Ampère busca fundar os fenômenos elétricos e magnéticos na mecânica dos fluídos. No entanto, não deixa de ser interessante considerar que, desde sua juventude, Ampère já estabelece essa busca.

Em 1804, Ampère parte a Paris onde se estabelece até o fim de sua vida. Em 1807, ele é eleito membro da academia de ciências, sobretudo por seus trabalhos de matemática, e ocupa a cadeira deixada por Lagrange. Em 11 de setembro de 1820, François Arago repete as experiências da ação do fio condutor sobre a agulha, realizadas por Oersted. Com isso, Ampère abre uma nova fase de pesquisas e vê claramente a possibilidade de 
fundar uma nova ciência, seu projeto de juventude. Uma carta ao seu filho, datada de 19 de setembro, relata bem seu entusiasmo:

Depois que eu ouvi falar pela primeira vez da bela descoberta do Sr. Oersted, professor em Copenhague, sobre a ação das correntes galvânicas sobre a agulha magnetizada, eu pensei nela continuamente e eu não fiz nada além de escrever uma grande teoria sobre esses fenômenos e todos aqueles já conhecidos sobre o ímã, e não deixei de tentar realizar experiências indicadas por esta teoria. Todas elas tiveram êxito e elas me fizeram conhecer novos fatos. (AMPÈRE, 1820 apud BLONDEL, 1982, p. 45, tradução nossa).

Ampère inicia uma fase de intensa pesquisa que compreende o período de 18 de setembro de 1820 a 15 de janeiro de 1821. Nesse período, ele realiza nove leituras na Academia de Ciências. Um elemento curioso é que Ampère anuncia todas as suas conclusões já na primeira leitura, uma semana após ele ver a demonstração da experiência de Oersted realizada por Arago. Nela, afirma ter feito experiências que comprovariam suas conclusões. Todavia, suas descrições dessas experiências são muito vagas, e nenhum dado conclusivo é apresentado. Dois anos depois, quando publica uma coletânea das leituras realizadas nesse período, Ampère admite que, na primeira delas, do dia 18 de setembro de 1820 e que será nosso objeto do estudo, ainda não havia realizado as experiências, mas somente pensado em como elas seriam (AMPÈRE, 1822). Assim, as experiências somente foram realizadas posteriormente, sendo apresentadas paulatinamente nas leituras dos dias 6, 16 e 30 de outubro e 6 e 13 de novembro, onde os resultados efetivamente aparecem.

Aqui temos um ótimo exemplo de quanto o trabalho de criação, apesar de se referir à realidade e nela se basear, vai 
além do que um dado objetivo ou sistemático permite. Apenas com as indicações dadas pela experiência de Oersted, Ampère constrói um novo corpus explicativo que, a posteriori, explica certos dados que são obtidos através de um grupo de experiências por ele realizadas.

O primeiro mémoire lido por Ampère é, do ponto de vista de processos criativos, o mais interessante. Seu esforço inicial é focado na possibilidade de criarmos novas condições de pensarmos os fenômenos e, durante este processo, o autor já antecipa em sua mente muitos resultados, que comporão sua argumentação. Apesar disso tudo, Ampère anuncia seu projeto da seguinte maneira:

As experiências que eu fiz sobre a ação mútua dos condutores que estão em comunicação com as extremidades de uma pilha voltaica me mostraram que todos os fatos relativos a esta ação podem ser reduzidos a dois resultados gerais, que nós devemos considerar de início como unicamente dados pela observação, ao esperar que nós pudéssemos os levar a um princípio único, ao determinar a natureza e, se possível, a expressão analítica da força que os produz. Eu começarei por enunciá-los sob a forma que me parece a mais simples e a mais geral. (AMPÈRE, 1820/1885, p. 48-49, tradução nossa)

Um primeiro elemento importante em relação ao conteúdo da citação anterior é a consideração que há uma ação mútua entre dois condutores. Aqui ele antecipa sutilmente suas conclusões e reorienta o cenário de investigação das interações entre ímãs e correntes elétricas, para uma relação entre correntes elétricas. Em muitas passagens, Ampère insiste bastante nessa afirmação. Podemos considerá-la como fundamental para seu projeto de unificação, pois, se as ações de 
diversos fenômenos devem ser reduzidas a uma mesma causa, estas devem ser mútuas, mesmo quando consideramos corpus que, a princípio, parecem ter naturezas diferentes. Este é o ponto que o autor buscará chegar. Logo em seguida, ele apresenta o primeiro dos dois resultados gerais:

Ação diretiva. Quando um ímã e um condutor agem um sobre o outro, e no caso em que um deles estando fixo, o outro só pode girar no plano perpendicular à mais curta distância do condutor e do eixo do ímã, aquele que é móvel tende a se mover, de maneira que as direções do condutor e do eixo do ímã formem um anglo reto, e que o polo do ímã que aponta habitualmente o norte esteja à direta disso que nós chamamos comumente a corrente galvânica, denominação que eu creio dever mudar para a de corrente elétrica, e o polo oposto a sua direita, e a linha que mede a mais curta distância do condutor e o eixo do ímã reencontra a direção desse eixo entre os dois polos. (AMPÈRE, 1820/1885, p. 49-50, tradução nossa)

Este resultado pode parecer, a princípio, apenas uma repetição do que Oersted já havia afirmado anteriormente, quando mostrava o desvio da agulha da bússola pelo fio ligado à bateria. No entanto, Ampère considera que a experiência de Oersted não deixa isso claro por misturar efeitos produzidos pela corrente elétrica com os do próprio campo magnético da Terra. Para superar esta limitação, propõe um instrumento no qual a agulha pode ser disposta em um plano vertical e perpendicular ao meridiano magnético da Terra, podendo, assim, evitar os efeitos do próprio campo terrestre. Esse resultado preciso é importante para Ampère por destacar que o ângulo formado é exatamente reto, algo que o postular que duas correntes ficam sempre paralelas. Ele concluirá que nos ímãs há correntes 
internas que são perpendiculares aos seus polos. Assim, uma agulha fica perpendicular ao fio, pois suas correntes internas estão paralelas ao mesmo. Seguindo ainda essa ideia, o autor indica que as ações são mútuas, mesmo se tratando da interação do fio com o ímã. Com isso, Ampère parte de um resultado já aceito, o desvio da agulha, para começar sua argumentação que envolverá várias dimensões desse conjunto de fenômenos.

Ainda nesse extrato, temos um elemento importante. A ideia de corrente elétrica como um movimento organizado e contínuo da eletricidade não existia. Como o projeto de Ampère é o de reduzir todos os fenômenos magnéticos à interação entre correntes, é somente neste contexto que a própria ideia de corrente se estabelece. $\mathrm{O}$ segundo resultado geral apresentado por Ampère é enunciado da seguinte forma:

Ação atrativa ou repulsiva. Esse segundo resultado geral consiste, $1^{\circ}$ no que um condutor tem suas pontas juntas às duas extremidades de uma pilha voltaica, e um ímã cujo eixo faz um ângulo reto com a direção da corrente que ocorre neste condutor conformemente às definições precedentes, se atraem quando o polo austral está à esquerda da corrente que age sobre ele, quer dizer, quando a posição é aquela que o condutor e o ímã tendem a tomar em virtude de sua ação mútua, e se repelem quando o polo austral do ímã está à direta da corrente, quer dizer, quando o condutor e o ímã são mantidos na posição oposta àquela que eles tendem a se colocar mutuamente. (AMPÈRE, 1820/1885, p. 51-52, tradução nossa)

Com isso, o autor estabelece um novo efeito que não havia sido observado. Podemos afirmar que este segundo princípio será a base de toda formulação matemática feita por Ampère 
posteriormente. Para fundamentá-lo, ele apresenta uma experiência na qual uma agulha era disposta verticalmente, tendo um de seus polos localizados na mesma altura de um fio condutor horizontal. Com este instrumento, o autor afirma ter produzido atrações e repulsões, de acordo com o sentido da corrente produzida no condutor.

Logo após o anúncio de seu segundo resultado geral, Ampère reafirma a importância de reciprocidade dos efeitos e busca ressaltar o caráter de unidade estabelecido por eles. Neste mesmo mémoire, ele ainda declara que os mesmos efeitos produzidos pela corrente elétrica no condutor eram produzidos pela própria pilha. Isto traz mais um caráter inovador na sua obra, pois, nessa época, não era óbvio imaginar que os fluídos galvânicos tinham as mesmas propriedades dos fluídos elétricos. Ele estabelece que internamente às pilhas também há a produção de corrente elétrica. Esse fato, mesmo sendo uma constatação indireta, ajuda a corroborar seu projeto de busca de uma causa única (neste caso, a existência de correntes elétricas) como explicação de todos os fenômenos eletromagnéticos. Baseando-se nessas formulações, Ampère irá "concluir" que a causa do magnetismo terrestre é a existência de correntes elétricas na Terra.

[...] a ideia mais simples, e aquela que se apresenta imediatamente a aquele que gostaria de explicar esta direção constante da agulha, não seria ela de admitir na Terra uma corrente elétrica, em uma direção tal que o norte se acharia à esquerda de um homem que, deitado sobre a superfície para ter a face virada do lado da agulha, receberia essa corrente na direção dos seus pés à sua cabeça, de onde concluímos que ela ocorre de leste a oeste, em uma direção 
perpendicular ao meridiano magnético? (AMPÈRE, 1820/1885, p. 55-56, tradução nossa)

Nesse momento, ele define o que hoje chamamos de "observador de Ampère". A imagem a seguir vem de um de seus manuscritos:

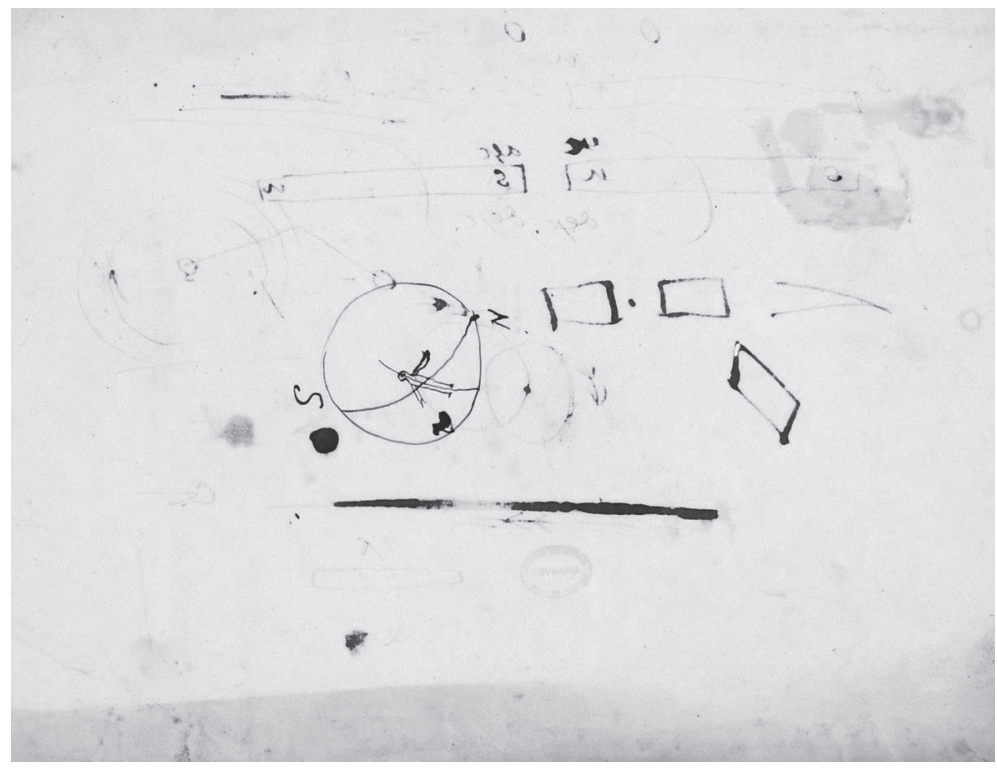

Figura 1 - Le "bonhomme d'Ampère" Fonte: Ampère (1820/2005).

A direção estabelecida para corrente é a mesma para a qual ele pode verificar em suas experiências. Após essa, afirmação ele explorará a possibilidade de um arranjo mais ou menos aleatório de metais poder produzir correntes internamente à Terra. Ele sugere que não é pelo fato que na disposição de uma pilha, com placas de cobre e zinco, esses efeitos sejam intensificados, que deveríamos considerar impossível a formação de 
correntes por outros metais os quais, no caso da Terra, têm a vantagem de se acumular por todo o seu perímetro. Ampère ainda buscará partir da existência de correntes na Terra para explicar outros fenômenos.

A elevação da temperatura que ocorre nos condutores das correntes elétricas deve ocorrer também no globo terrestre. Não seria esta a causa do calor interno constatado recentemente pelas experiências relatadas, em uma das últimas sessões da Academia, por um de seus membros cujos trabalhos sobre o calor fizeram esta parte da Física entrar no domínio das matemáticas? E quando nós verificamos que esta elevação de temperatura produz, no caso de uma corrente muito energética, uma incandescência permanente, acompanhada da mais viva luz, sem combustão nem perda de substância, nós não poderíamos concluir que os globos opacos só são assim por causa da pouca energia das correntes elétricas que se estabelecem nele, e achar nas correntes mais ativas a causa do calor e da luz dos globos que brilham por eles mesmos? (AMPÈRE, 1820/1885, p. 57, tradução nossa)

É interessante notar como a ideia de correntes elétricas no interior da Terra se apresenta clara a Ampère e como ela lhe possibilita explicar uma diversidade grande de fenômenos. Ele finaliza sua leitura, que será retomada na sessão seguinte da academia, considerando que esse mesmo princípio que explica a magnetização da Terra deve ser a causa da magnetização dos ímãs.

Agora, se as correntes elétricas são a causa da ação diretiva da terra, as correntes elétricas serão também a causa daquelas de um ímã sobre outro ímã, de onde se segue que um ímã deve ser considerado como um 
conjunto de correntes elétricas que ocorrem nos planos perpendiculares a seu eixo, dirigidas de maneira que o polo austral, que se coloca do lado do norte, encontra-se à direita de suas correntes, pois ela está sempre à esquerda de uma corrente colocada fora do ímã, e que faz face na direção paralela, ou, mais ainda, essas correntes se estabelecem de início no ímã, seguindo as curvas fechadas as mais curtas, seja da esquerda à direita, seja da direta à esquerda, e então a linha perpendicular aos planos dessas correntes tornam-se o eixo do ímã, e suas extremidades tornam-se os polos. Assim, a cada um dos polos de um ímã, as correntes elétricas que o compõem são dirigidas seguindo curvas fechadas concêntricas. Eu imitei esta disposição à medida que ela era possível com uma corrente elétrica, enrolando o fio condutor em espiral, esta espiral era formada com um fio de latão e terminada por duas porções retilíneas desse mesmo fio, que estavam fechadas em dois tubos de vidro, afim que elas não se comunicassem e pudessem ser ligadas às duas extremidades da pilha. (AMPÈRE, 1820/1885, p. 57-58, tradução nossa)

O mais marcante desse trabalho de Ampère é ele não ter partido dos dados que ele dizia obter. Quando o autor apresenta esse texto, ele não havia realizado as experiências que declara. Ele concebe uma ideia muito nova e a desenvolve com base em razões físicas e, também, metafísicas. Sua concepção de unidade entre os fenômenos é o principal motor de sua criação.

\section{Considerações finais}

Inicialmente, este capítulo apresentou uma corrente filosófica que atribui grande peso aos fatos e observações na 
elaboração do conhecimento científico. As concepções empírico-indutivistas consideram a possibilidade de se elaborar leis e teorias a partir de uma análise sistemática dos dados, na qual a correta organização dos mesmos permite a consolidação do conhecimento.

Consideramos que a análise histórica de um episódio da ciência não tem a função de afirmar ou refutar uma determinada corrente filosófica. Talvez a maneira mais delicada de relacionar história e filosofia da ciência seja através da tentativa de problematizar visões sobre o conhecimento, buscando uma postura reflexiva e crítica sobre ambas.

Retomando os casos históricos aqui apresentados, vemos que uma experiência e as informações obtidas por meio dela são fundamentais para a elaboração da ciência. Assim, podemos afirmar que a eletrodinâmica foi desenvolvida com forte apelo empírico. Contudo, não podemos Ihe superestimar, como se um experimento nos permitisse desvelar a realidade por completo. Isto é, devemos ter cuidado com o uso da palavra "descoberta", pois esta nos leva, muitas vezes, a refletir que os conceitos que utilizamos para pensar o mundo estão prontos, esperando apenas "serem encontrados".

Verificar que a experiência de Oersted foi interpretada por no mínimo três formas bastante distintas é algo que nos permite pensar sobre o quanto um dado é objetivo. Podemos considerar que, em alguma medida, as observações são carregas de teoria, utilizando esse termo de modo livre. O que vemos acaba sendo influenciado pelo que acreditamos existir, visto que esses pressupostos ontológicos podem ter origens diversas.

Tanto Oersted quanto Ampère buscava uma unidade fundamental para a natureza. Contudo, seus pensamentos foram levados a caminho muito diferentes. Enquanto o primeiro 
buscou apoio em visões mecanicistas que consideravam a existência de fluídos, o segundo procurou uma unidade fundamental que permitisse uma elaboração matemática para interações, propondo a existência de correntes elétricas em diferentes corpos.

A interpretação do mundo envolve um complexo processo, por meio do qual diferentes elementos de nossas bagagens culturais se entrecruzam. E, ao ensinarmos ciências, precisamos estar constantemente vigilantes sobre esse processo, pois, somente assim, como professores, seremos capazes de dialogar com nossos alunos, valorizando suas dúvidas e permitindo a construção de novos olhares sobre a natureza.

\section{Referências}

AMPÈRE, André-Marie. Introduction du Mémoire Inédit et Inachavé sur l'Electricité et le Magnetisme de 1801. In: BLONDEL, Christine. A-M Ampère et la Création de l'Electrodynamique (1820-1827). BNF: Paris, 1982.

De l'Action Exercée sur un Courant Électrique par un Autre Courant, Le Globe Terrestre ou un Aimant. In : SOCIETÉ FRANCAISE DE PHYSIQUE. Collection de Mémoires Relatifs a la Physique - Tome II. Gauthier-Villars: Paris, 1820/1885. p. 7-54.

Recueil d'Observations Electrodynamiques. GauthierVillars: Paris, 1822/1885.

Figure "Le bonhomme d'Ampère" In : AMPÈRE L'HISTOIRE DE L'ÉLECTRICITÉ, 1820/2005. Disponível em: <http://www.ampere.cnrs.fr/manuscrits/avoir/avoir-electro. php\#bonhomme>. Acesso em: 5 jul. 2016. 
AUDOUZE, Jean. Moi, Benjamin Franklin. Dunod: Paris, 2006.

BLONDEL, Christine. A-M Ampère et la Création de I'Electrodynamique (1820-1827). BNF: Paris, 1982.

GIL-PÉREZ, Daniel; MONTORO, Isabel Fernández; ALÃ, Jaime Carrascosa; CACHAPUZ, António; PRAIA, João. Para uma Imagem não Deformada do Trabalho Científico. Ciência \& Educação, v. 7, n. 2, p. 125-153, 2001.

GURGEL, Ivã. Elementos para uma Poética das Ciências: Fundamentos Teóricos e Implicações ao Ensino. 2010. 301 f. Tese (Doutorado em Educação) - Faculdade de Educação, Universidade de São Paulo, São Paulo, 2010. Disponível em: <http://www.teses.usp.br/teses/disponiveis/48/48134/ tde-09092010-105921/en.php>. Acesso em: 5 jul. 2016.

HANSON, Norwood Russell. Observação e Interpretação. In: MORGENBESSER, Sidney (Org.). Filosofia da Ciência. Tradução de Leônidas Hergenberg; Octany Silveira da Mota. Cultrix: São Paulo, 1974, p. 127-141.

HÁÜY, René. Traite Élémentaire de Physique. Adolphe Delahays: Paris, 1821/1855.

HOFMANN, James. André-Marie Ampère. Blackwell Publishers: Boston, 1995.

LOCQUENEUX, Robert. Ampère: Encyclopédiste et Métaphysicien. EDP Sciences: Lille, 2008.

MARTINS, Roberto de Andrade. Oersted e a descoberta do eletromagnetismo. Cadernos de História e Filosofia da Ciência, v. 10, p. 89-114, 1986. 
MILL, Jonh Stuart. Sistema de Lógica Indutiva e Dedutiva. Abril Cultural: São Paulo, 1843/1978.

OERSTED, Hans Christian. Experiências sobre o efeito do Conflito Elétrico sobre a Agulha Imantada. Cadernos de História e Filosofia da Ciência, v. 10, p. 115-122, 1820/1986.

ZANETIC, João; MOZENA, Erika Regina. Evolução dos Conceitos da Física. São Paulo: IFUSP, 2012. 


\section{UMA BOMBA EM VERSO, PROSA E CANÇÃO: HISTÓRIA, ARTE E TECNOLOGIA NAS AULAS DE FÍSICA}

Winston Gomes Schmiedecke Paulo Alves Porto

\section{Introdução}

O êxito do Projeto Manhattan em produzir as primeiras bombas atômicas da história deve, em grande parte, ser atribuído ao trabalho de um grupo de cientistas que somente pôde ser reunido em torno de um objetivo comum em função do combate às forças do Eixo (Alemanha, Itália e Japão) pelos Aliados, na Segunda Grande Guerra Mundial. A imigração forçada para os EUA, de vários cientistas europeus de renome, tais como Enrico Fermi (1901-1954), Leó Szilárd (1898- 1964), Niels Bohr (18851962) e Edward Teller (1908-2003), mostrou-se determinante para os fins do Projeto Manhattan. Foi o trabalho conjunto dessas personalidades com cientistas estadunidenses, além do esforço de milhares de trabalhadores, que possibilitou o enorme desenvolvimento científico e tecnológico observado, alcançado em um espaço de tempo incomum na história da humanidade. 
A conjunção de ideias e esforços desses cientistas não ocorreu de forma espontânea, ou seja, não foi determinada pelo alinhamento de interesses oriundos das pesquisas em ciências desenvolvidas de forma individual e anterior às mudanças provocadas pela guerra. Não é possível fazer uma projeção do que esses cientistas poderiam ter oferecido à sociedade se, em vez de se dedicarem ao Projeto Manhattan, houvessem prosseguido em seus destinos e pesquisas anteriores. Contudo, é improvável que lograssem êxito - ou mesmo que tivessem interesse - em produzir artefatos nucleares do porte das bombas lançadas sobre o Japão, em 1945.

Esse é um exemplo de influência, advinda do meio social, sobre os rumos tomados pela ciência e seus produtos, evidenciando que os cientistas nem sempre guiam suas pesquisas em uma direção escolhida ou pré-determinada por eles próprios. Teller, por exemplo, era conhecido no final da década de 1930 por seus trabalhos em química, utilizando a Teoria de Grupos para explicar fenômenos eletrônicos, até então sem qualquer relação com o fenômeno da fissão nuclear, que já era estudado pelo grupo de Fermi. Todavia, no contexto aqui abordado, a presença de Teller está associada a fatos independentes de suas contribuições para a química.

Muitos são os setores da sociedade civil que estão atentos e sensíveis às consequências geradas pelos resultados da ciência. Como resultado, vozes dissonantes podem expressar suas críticas por meio de variadas formas de manifestações culturais, como literatura, cinema, música, teatro etc. Nesse sentido, oferecer aos estudantes a possibilidade de apreender e integrar essas manifestações com o conhecimento científico seria uma forma de enriquecer com significados e sentidos o aprendizado dos conteúdos de ciências no ensino médio. No presente trabalho, são 
abordadas manifestações culturais relacionadas a um tema de grande impacto sobre a sociedade: a bomba atômica.

Considerando a importância de se respeitar as características e contingências de cada contexto em que os docentes se encontram inseridos profissionalmente, optamos aqui por oferecer um conjunto de sugestões alinhadas com os conteúdos curriculares de Física para o ensino médio, apresentando materiais e atividades didáticas voltadas ao desenvolvimento dos temas e evidenciando os recursos didáticos envolvidos.

O conteúdo científico mais claramente associado ao episódio descrito neste trabalho é a física nuclear, ramo da ciência que possui inúmeras aplicações no âmbito das diversas frentes de pesquisa exploradas a partir de seus fundamentos. Uma tentativa de se contar uma história da física nuclear que abrangesse todas essas investigações e, também, as tecnologias delas decorrentes, seria uma tarefa hercúlea e, tratando-se dos propósitos didáticos de aplicação desse material, fadada a oferecer informações pontuais e desarticuladas, que pouco valor e sentido teriam para os estudantes. No contexto escolar da física no ensino médio, a qualidade das articulações realizadas é mais importante que a quantidade de informações fornecidas, sendo fundamental que os estudantes consigam associar as informações àquilo que está presente em seu cotidiano.

Um documento recente, que reforça a relevância dos assuntos abordados por essa atividade, é a Base Nacional Comum Curricular (BNCC). Sua versão preliminar, destinada a passar por rodadas de negociação junto aos diversos setores da sociedade, declarava ser fundamental que as aulas de física do ensino médio, no trabalho com a unidade de conhecimento Matéria e radiação em sistemas e processos naturais e tecnológicos, abrissem espaço para o respectivo histórico associado. Textualmente, 
a BNCC sugeria ser necessário promover junto aos alunos a análise dos "[...] vários eventos envolvendo o uso da energia nuclear, desde a explosão de bombas atômicas, o vazamento de usinas de geração de energia até descarte de material radioativo" (BRASIL, 2015, p. 218).

\section{Aportes teóricos e metodológicos}

As atividades didáticas sugeridas neste trabalho visam promover o diálogo entre duas áreas do conhecimento: a História da Ciência e o Ensino de Ciências. Assim sendo, alguns referenciais teóricos e metodológicos foram utilizados para dar sustentação a essa aproximação.

No que se refere à utilização de critérios historiográficos, a elaboração do material buscou contemplar a contemporânea historiografia da ciência, ao priorizar: a análise pontual de um caso histórico, privilegiando a investigação de um acontecimento específico; a apresentação das ideias atreladas ao contexto sócio-histórico-cultural em que foram propostas; e o realce à influência de fatores externos (de natureza psicológica, política e social, por exemplo) na prática científica (BALDINATO; PORTO, 2008; PORTO, 2010).

A escolha pelo emprego de recursos audiovisuais busca trabalhar conhecimentos específicos de maneira mais dinâmica e plural nas aulas de ciências, recorrendo a uma linguagem mais próxima do cotidiano dos alunos em relação àquela que caracteriza os livros didáticos ou, ainda, os textos acadêmicos. Essa tendência tem sido discutida e explorada pela literatura especializada nas últimas décadas (CARVALHO, 1993; MORÁN, 1995; ARROIO; GIORDAN, 2006; REZENDE, 2008). 
Considerando a história da ciência como mais um entre os diversos recursos didático-pedagógicos atualmente disponíveis para o professor de ciências desenvolver os conteúdos de sua disciplina, a associação com outros recursos pode tornar seus resultados mais eficazes. Recente levantamento realizado junto a licenciandos em Física de duas instituições de ensino superior da cidade de São Paulo mostrou que a história e a filosofia da ciência (HFC) ainda enfrentam resistências e obstáculos para sua aproximação com a sala de aula:

Constatar que a HFC nem de longe se configura em uma estratégia didático-pedagógica ocupando espaço privilegiado dentre a preferência dos professores em formação reforça a necessidade de se propor outras formas de utilizá-la (em particular, a História da Ciência) nas aulas de Física da Escola Básica. Por exemplo, pode-se associá-la aos demais recursos disponíveis, com valores didáticos mais bem estabelecidos junto ao imaginário dos licenciandos, caso da Experimentação, da Abordagem CTS(A) e da Resolução de Problemas. (SCHMIEDECKE; TADEU NETO, 2015, p. 8)

É preciso, portanto, considerar que os futuros professores tenham a adequada fundamentação para lidar com essas temáticas e estratégias (SCHMIEDECKE; PORTO, 2014). Tendo em vista o cenário aqui delineado, propomos, neste trabalho, duas atividades, pautadas pela possibilidade de composição harmoniosa entre os diferentes aspectos que caracterizam os recursos didático-pedagógicos mobilizados. ${ }^{1}$ Além disso, sendo coerente com o tom de diálogo que procuramos manter com os docentes ao apresentar o material, delegamos aos professores a escolha,

\footnotetext{
1 As duas atividades aqui apresentadas foram extraídas de um conjunto original de onze atividades, propostas por Schmiedecke (2016).
} 
a articulação e o encadeamento das estratégias e atividades aqui sugeridas, a serem feitas em sintonia com seus propósitos didáticos e, principalmente, com a dinâmica de cada cotidiano profissional.

\section{Atividade 1: Documentários Projeto Manhattan e Luz Branca, Chuva Negra}

Com a devida antecedência, sugere-se ao docente solicitar que os alunos assistam ao documentário em vídeo "Projeto Manhatan", pertencente à série "Maravilhas Modernas", produzido em 2002 pelo canal de TV estadunidense The History Channel $^{2}$, por ser muito extenso para exibição em uma aula. Dentre outras informações, o vídeo apresenta as justificativas dos construtores das bombas atômicas para lançá-las sobre o Japão no ano de 1945.

$\mathrm{O}$ docente pode escolher previamente um grupo de 3 a 4 alunos, o qual ficaria encarregado de apresentar à classe uma breve exposição das principais informações presentes no vídeo, como uma síntese das ideias prévias para dar início às discussões. Após a apresentação feita pelo grupo, ainda na mesma aula, o docente apresenta aos alunos as seguintes questões:

I. Por que as forças armadas estadunidenses lançaram as duas bombas atômicas sobre as cidades japonesas de Hiroshima e Nagasaki, mesmo após o poderio militar do Japão já ter sido praticamente dizimado?

\footnotetext{
${ }^{2}$ As primeiras quatro partes do documentário, dubladas em português, estão disponíveis no site YouTube (2011a, 2011b, 2011c, 2011d) - faltando apenas a quinta e última parte, com cerca de sete minutos de duração. O vídeo original, em inglês, está disponível na íntegra, no mesmo site (YouTube, 2002).
} 
II. Referindo-se aos milhares de pessoas contratadas para trabalharem nos centros de produção do material físsil utilizado nas bombas do Projeto Manhattan, o historiador e jornalista Richard Rhodes faz o seguinte comentário: "Era duro conseguir operários durante a guerra. A solução dele [General Leslie Groves, dirigente máximo do projeto] foi pôr anúncios assim: 'não podemos dizer o que vocês farão, mas haverá bife na mesa todas as noites'”. Por outro lado, boa parte dos cientistas que trabalharam nesse empreendimento era composta por imigrantes europeus refugiados da guerra, que de maneira consciente se ofereceram ou aceitaram esse trabalho sem muito relutar. Em sua opinião, há alguma contradição nas posturas desses dois grupos? Por quê?

III. Sobre a corrida das duas superpotências do Pós-Guerra (EUA e URSS) voltada à constituição de arsenais nucleares, o cientista húngaro Edward Teller (1908-2003), naturalizado estadunidense, declarou: "O progresso não pode ser detido. Dizem-nos [i.e., aos cientistas] para deter o progresso. Temo que o progresso venha a ocorrer num país menos dedicado à paz do que nós [EUA]". Procure relacionar essa declaração de Teller com as restrições impostas pelas potências nucleares aos demais países do mundo, por meio do Acordo de Não Proliferação de Armas Nucleares.

IV. Ainda que não tenha colaborado diretamente com a execução das ações do Projeto Manhattan, Albert Einstein (1879-1955) foi responsável pela elaboração de uma teoria que forneceu importantes subsídios teóricos utilizados para a fabricação das bombas atômicas. Qual é o mais conhecido enunciado matemático que integra essa 
teoria, e de que forma ele ajuda a explicar o extraordinário poder destrutivo da explosão de bombas atômicas?

Com esse conjunto de questões, é possível desenvolver com os alunos discussões destinadas, respectivamente, a:

I. reforçar a importância do contexto sociopolítico nas pesquisas realizadas em ciência, bem como das decisões a respeito dos consequentes rumos tomados por suas aplicações tecnológicas;

II. situar os cientistas no mesmo plano das demais pessoas que constituem a sociedade civil, por diversas vezes forçadas a tomarem decisões que transcendem a compreensão dos limites éticos tradicionais; ou seja, em determinados momentos da vida, tanto os chamados "cidadãos comuns", como os cientistas, se submetem ao desempenho de trabalhos destinados à obtenção de resultados com os quais esses sujeitos não concordariam segundo suas crenças e valores pessoais;

III. evidenciar que a prática do veto realizada por parte das nações ditas "desenvolvidas" - geralmente acompanhado por boicotes e imposição de sanções à possibilidade de as tecnologias de ponta serem compartilhadas com as nações "em desenvolvimento" - é um dos fatores que concorrem para a manutenção do atraso científico destas últimas, e um dos responsáveis pelo aumento da desigualdade socioeconômica entre os diversos países do mundo;

IV. dar sentido para aquela que, talvez, seja a equação mais conhecida da física, apresentando aos alunos a equivalência entre massa e energia ("balanço energético") presente no processo de fissão nuclear, de modo que eles 
entendam de onde vem a energia liberada na explosão de uma bomba atômica, bem como o processo de aproveitamento dessa energia nas usinas termonucleares.

Terminado o primeiro bloco de aulas dessa atividade, passa-se ao trabalho com o documentário "Luz Branca, Chuva Negra: a destruição de Hiroshima e Nagasaki", produzido em 2007 pela também estadunidense $H B O^{3}$. Se o vídeo anterior expõe a opinião daqueles que venceram a corrida para a construção da bomba atômica (e a guerra), este outro documentário - dirigido pelo nipo-americano Steven Okazaki -, oferece a outra face da moeda, trazendo o relato de mais de uma dúzia de sobreviventes dos bombardeios nucleares, além de consequências derivadas do Projeto Manhattan não exploradas no documentário do The History Channel.

Trata-se de um vídeo longo, com quase 1h30min de duração. Portanto, é conveniente disponibilizar de antemão aos alunos as questões a serem discutidas em sala de aula, como forma de nortear sua atenção em relação a determinados fatos, presentes no vídeo, já selecionados para serem aprofundados. Nesse caso, o grupo escolhido para apresentar a síntese do documentário já ficaria responsável por iniciar, em sala de aula, a discussão das seguintes questões:

I. Os EUA são reconhecidos pela facilidade com que transformam conhecimentos científicos adquiridos em contextos de guerra em importantes aplicações tecnológicas para o uso civil. O vídeo destaca a proibição prevista na constituição japonesa, redigida com influência das forças de ocupação estadunidenses, no tocante à existência de forças armadas e à produção de armas no

3 Disponível em: <http://www.youtube.com/watch?v=--p1ZVMOUjw>. 
Japão ressurgido do Pós-Guerra. Todavia, o Japão é uma nação celebrada mundialmente pelo alto nível de desenvolvimento tecnológico de suas diversas empresas. O que poderia explicar esse aparente paradoxo?

II. O copiloto do avião que lançou a bomba sobre Hiroshima, Capitão Robert Lewis, participa do programa de TV destinado a homenagear Kiyoshi Tanimoto, religioso japonês que levantava fundos para as vítimas das bombas atômicas. Isso ocorreu em 1955, dez anos após o final da guerra. No programa, Lewis aparece fazendo doações para Tanimoto, segundo suas próprias palavras, "em nome da equipe que participou daquela missão, de minha empresa e de minha adorável família". Conforme destacado pelo apresentador do programa, a mencionada empresa era a Henry Heide Ltd., atuante no ramo de balas e gomas de mascar. A princípio, esse fato soa estranho, pois, como herói de guerra, seria razoável imaginar que Lewis tivesse continuado sua carreira profissional como militar. Faça uma breve pesquisa visando explicar a razão do Capitão Lewis e vários outros militares estadunidenses atuantes na Segunda Grande Guerra Mundial terem ido trabalhar na iniciativa privada ao final da guerra, realidade que, na época, gerou consequências diretas no modo de participação das mulheres no mercado de trabalho dos EUA.

III. É possível estabelecer relações entre os dois documentários. Por exemplo, ao término da Segunda Grande Guerra, a possibilidade de aniquilamento da população mundial, concretizada pela constatação do poder das bombas atômicas, trouxe a sensação de absoluta impotência e desconfiança às pessoas, quaisquer que fossem 
as sociedades em que viviam. Apesar disso, durante a Guerra Fria, os governos dos EUA e do Japão conduziram suas ações de maneiras muito diferentes no âmbito dos usos da energia nuclear. Enquanto os EUA seguiram investindo pesadamente no desenvolvimento de armas nucleares - em quantidade e variedade -, o Japão limitou-se a investir recursos materiais e humanos no sentido de utilizar a tecnologia nuclear para a geração de energia elétrica e, também, de descobrir novas possibilidades de aplicação da energia nuclear na resolução de problemas cotidianos da sociedade. Como resultado, o Japão conta atualmente com uma série de indústrias que dominam e comercializam a tecnologia nuclear em nível mundial. A empresa nipônica Toshiba, por exemplo, desenvolveu-se a ponto de comprar, em 2006, a estadunidense Westinghouse - responsável, nos anos 1970, pela construção da usina nuclear de Angra I, no Brasil. A partir do levantamento de informações junto a fontes fidedignas, faça uma comparação entre os exemplos do Japão e do Brasil na exploração e nos usos da energia nuclear. Não se esqueça de citar suas fontes.

Dentre outras possibilidades, essas questões permitem ao docente discutir importantes aspectos que ajudam a desmitificar a prática científica, bem como explorar fatos cotidianos e aplicações tecnológicas cuja origem é desconhecida pela maioria dos alunos. Seguem-se comentários sobre cada questão, visando lançar luz sobre alguns aspectos passíveis de serem explorados:

I. Não existe um único, inequívoco e universal método científico capaz de gerar resultados invariavelmente equivalentes em contextos sociais distintos. Ou seja, a 
"fórmula" de sucesso para as relações entre ciência, tecnologia e sociedade que funciona para um determinado país pode não servir para outros, fato refletido nas políticas de Estado voltadas ao investimento em educação, pesquisa e desenvolvimento social. Este é o caso de EUA e Japão, nações constituídas com base em influências geográficas e culturais muito diferentes;

II. Cerca de 16 milhões de pessoas serviram às Forças Armadas dos EUA no contexto da Segunda Grande Guerra Mundial. Em sua absoluta maioria, esse contingente era formado por pessoas do sexo masculino. Como forma de manter a economia em funcionamento, as empresas passaram a contratar um número expressivo de mulheres para ocupar os postos vagos devido à guerra. Contudo, terminada a guerra, os homens retornaram aos EUA, cujo governo não tinha mais motivo para manter o mesmo contingente de militares e demais profissionais em sua folha de pagamento. Como forma de reinserir tais sujeitos no mercado de trabalho, as mulheres foram "convidadas" a procurar outras maneiras para se manterem economicamente ativas - e, de preferência, sem abandonarem seus lares. Nesse momento, ganharam espaço as diversas empresas que baseavam a venda direta de seus produtos em reuniões promovidas por muIheres em suas próprias residências, dentre as quais um exemplo bastante conhecido é o da fabricante de vasiIhas plásticas Tupperware. Sob um olhar mais abrangente, trata-se de mais um reflexo das complexas relações envolvendo ciência, tecnologia e sociedade, pois parte da demanda pelo aumento de empregos, diretos ou indiretos, surgida durante a guerra, ocorreu em função da instalação do Projeto Manhattan; e 
III. A Westinghouse foi a empresa que vendeu ao Brasil o projeto da usina termonuclear Angra I, e a construiu nos anos 1970, pouco mais de 25 anos após o final da Segunda Grande Guerra Mundial. Passadas três décadas, e sendo unicamente autorizado a trabalhar com pesquisas destinadas aos usos pacíficos da energia nuclear, o Japão atingiu um nível de desenvolvimento nessa área que permitiu às suas empresas a aquisição de tradicionais conglomerados estadunidenses. O Brasil parece ter trilhado a contramão desse processo, visto que segue tentando superar uma série de dificuldades tecnocientíficas para concluir a usina Angra III.

Ao utilizar os dois documentários destacados, o docente permite aos estudantes confrontarem os objetivos e interesses dos elaboradores e veiculadores desses materiais e, também, perceberem suas possibilidades e limitações enquanto recursos didáticos. Existem diferenças significativas entre trabalhos de reconhecido valor historiográfico e aqueles destinados essencialmente à divulgação científica. Sobre essa realidade, Rezende (2008, p. 2-3) foi particularmente preciso, ao afirmar que,

[...] por visarem frequentemente à divulgação, os filmes científicos tendem a "tomar um partido", ou seja, a defender uma determinada teoria ou visão em detrimento de outras. Neste caso, eles precisam ser analisados tanto como elementos que se integram às disputas pelo reconhecimento público da ciência, quanto como obras que resultam de determinadas configurações das intenções de seus autores e de seus contextos de produção.

Nessa atividade, os estudantes têm a oportunidade de refletir sobre as posições dos "vencedores", dos "vencidos" 
e dos países "periféricos" em relação à ciência e a tecnologia. Questões como a concepção de ciência como conhecimento universalmente compartilhado, e a suposta neutralidade da ciência, podem ser discutidas nesse contexto.

\section{Atividade 2: Poesia (Rosa de Hiroshima) e Música (Enola Gay)}

Os resultados das principais investigações feitas em ciência afetam a sociedade como um todo, sendo retratados a partir dos mais diversos ângulos e formas. A Literatura e as Artes, por exemplo, sempre estiveram atentas a essa relação. Nesse sentido, a história é rica em exemplos de escritores e artistas que expressaram os sentimentos mais comuns e contraditórios da sociedade civil (preocupação, confiança, admiração, contrariedade, esperança, desilusão, euforia, consternação) envolvendo as realizações do conjunto de ações e descobertas científicas com os quais se depararam ao longo de suas existências.

Com o objetivo de realizar junto aos alunos uma leitura crítica e atenta de exemplos associados à relação estabelecida historicamente entre a ciência e outras manifestações culturais, a presente atividade utiliza uma conhecida poesia do brasileiro Vinicius de Moraes (1913-1980) e, também, uma canção da banda britânica OMD (Orchestral Manoeuvers in the Dark).

Compostas com uma diferença de 26 anos entre si, em momentos distintos da Guerra Fria, Rosa de Hiroshima ${ }^{4}$ (1954)

\footnotetext{
4 Ou Rosa de Hiroxima, na grafia originalmente utilizada por Vinicius de Moraes e atualmente em desuso no Brasil. O poema se tornou bastante conhecido após ser musicado por Gerson Conrad e gravado pela banda Secos e Molhados, em disco de 1973. Posteriormente, a canção foi regravada pelo ex-vocalista
} 
e Enola Gay (1980) expressam em suas letras a indignação de duas sociedades separadas no tempo e no espaço, mas unidas pelo sentimento comum de reprovação às centenas de milhares de mortes provocadas pelo lançamento das bombas atômicas em 1945 e, também, pela sensação de impotência diante do alcance dos produtos obtidos a partir da tecnologia nuclear.

As guerras que se sucederam em países da Ásia (Indochina, Coreia, Vietnã) e outros conflitos internacionais (construção do muro de Berlim, posicionamento de mísseis soviéticos em Cuba, deflagração da "Primavera de Praga" etc.) representaram o risco premente de encaminhamento para uma "solução" nuclear. Tal realidade não poderia passar incólume ao olhar de personalidades ligadas aos diversos setores da sociedade civil, dando origem a críticas e manifestações de caráter pacifista.

Apresentamos, no Quadro 1, o poema Rosa de Hiroshima e a letra de Enola Gay, acompanhada de sua tradução para o português. Há diversas maneiras de se explorar esse material, em sintonia com as intenções e a sensibilidade do docente em relação às possibilidades de interlocução a serem promovidas em cada particular contexto didático ${ }^{5}$.

No caso de se propor uma leitura crítica aos alunos, esta poderia se centrar na identificação das referências feitas pelos autores de cada letra (Rosa de Hiroshima e Enola Gay) em relação às bombas lançadas sobre o Japão, no final da Segunda Grande Guerra.

dos Secos e Molhados, Ney Matogrosso, sendo uma das mais conhecidas do repertório de sua bem-sucedida carreira solo.

5 Outro texto de autor brasileiro que poderia ser utilizado em atividade semeIhante é o poema A Bomba, de Carlos Drummond de Andrade (1902-1987). Entretanto, por ser muito extenso e fazer uso de um vocabulário mais complexo, que requer uma discussão mais elaborada, evitamos abordá-lo no contexto deste trabalho. 
Quadro 1 - Letras de duas manifestações artísticas que se referem à bomba atômica lançada sobre Hiroshima

\begin{tabular}{|c|c|c|}
\hline \multirow{2}{*}{$\begin{array}{l}\text { Rosa de Hiroshima } \\
\text { (Brasil - 1954) }\end{array}$} & \multicolumn{2}{|l|}{$\begin{array}{l}\text { Enola Gay } \\
\text { (Inglaterra, 1980) }\end{array}$} \\
\hline & Original (Inglês) & Tradução (Português) \\
\hline $\begin{array}{l}\text { Pensem nas crianças } \\
\text { Mudas telepáticas } \\
\text { Pensem nas meninas } \\
\text { Cegas inexatas } \\
\text { Pensem nas mulheres } \\
\text { Rotas alteradas } \\
\text { Pensem nas feridas } \\
\text { Como rosas cálidas } \\
\text { Mas oh não se esqueçam } \\
\text { Da rosa da rosa } \\
\text { Da rosa de Hiroshima } \\
\text { A rosa hereditária } \\
\text { A rosa radioativa } \\
\text { Estúpida e inválida } \\
\text { A rosa com cirrose } \\
\text { A antirrosa atômica } \\
\text { Sem cor sem perfume } \\
\text { Sem rosa sem nada. }\end{array}$ & $\begin{array}{l}\text { Enola Gay, } \\
\text { you should have stayed at home } \\
\text { yesterday } \\
\text { Words can't describe } \\
\text { the feeling and the way you lied } \\
\text { These games you play } \\
\text { they're going to end in more than } \\
\text { tears someday } \\
\text { Enola Gay, } \\
\text { it shouldn't ever have to end this } \\
\text { way } \\
\text { It's eight fifteen } \\
\text { and that's the time that it's } \\
\text { always been } \\
\text { We got your message on the radio } \\
\text { Conditions normal and you're } \\
\text { coming home } \\
\text { Enola Gay, } \\
\text { is mother proud of little boy } \\
\text { today? } \\
\text { This kiss you give, } \\
\text { it's never ever going to fade away } \\
\text { Enola Gay, } \\
\text { it shouldn't ever have to end this } \\
\text { way } \\
\text { Enola Gay, } \\
\text { it shouldn't fade in our dreams } \\
\text { away } \\
\text { It's eight fifteen } \\
\text { and that's the time that it's } \\
\text { always been } \\
\text { We got your message on the radio } \\
\text { Conditions normal and you're } \\
\text { coming home } \\
\text { Enola Gay, } \\
\text { is mother proud of little boy } \\
\text { today? } \\
\text { This kiss you give, } \\
\text { it's never ever going to fade away }\end{array}$ & $\begin{array}{l}\text { Enola Gay, } \\
\text { você deveria ter ficado em } \\
\text { casa ontem } \\
\text { Palavras não podem descrever } \\
\text { o sentimento e o jeito com que } \\
\text { você mentiu } \\
\text { Qualquer dia, seus jogos } \\
\text { serão mais que sofrimento } \\
\text { Enola Gay, isso nunca deveria } \\
\text { ter terminado desse jeito } \\
\text { São } 8 \text { h15 e essa é a hora que } \\
\text { sempre foi } \\
\text { Recebemos sua mensagem } \\
\text { pelo rádio } \\
\text { As condições estão normais e } \\
\text { você está voltando para casa } \\
\text { Enola Gay, } \\
\text { a mãe hoje está orgulhosa de } \\
\text { seu garotinho? } \\
\text { O beijo que você dá jamais irá } \\
\text { desaparecer } \\
\text { Enola Gay, isso nunca deveria } \\
\text { ter terminado desse jeito } \\
\text { Enola Gay, isso não deveria } \\
\text { ter desaparecido dos nossos } \\
\text { sonhos } \\
\text { São } 8 \text { h15 e essa é a hora que } \\
\text { sempre foi } \\
\text { Recebemos sua mensagem } \\
\text { pelo rádio } \\
\text { As condições estão normais e } \\
\text { você está voltando para casa } \\
\text { Enola Gay, } \\
\text { a mãe hoje está orgulhosa de } \\
\text { seu garotinho? } \\
\text { O beijo que você dá jamais irá } \\
\text { desaparecer }\end{array}$ \\
\hline
\end{tabular}

Fonte: Elaborado pelos autores.

${ }^{6}$ Disponível em: http://www.viniciusdemoraes.com.br/pt-br/poesia/poesias-avulsas/ rosa-de-hiroxima. Acesso em: 03 out. 2016.

7 Letra extraída da versão interpretada no filme Urgh! A Music War (1981). Disponível no site oficial da banda: <http://www.omd.uk.com/video/enola_gay_live>.

8 Tradução nossa. 
O Quadro 2, a seguir, apresenta alguns termos e expressões presentes nas letras destacadas, que constituem uma visão do mencionado episódio histórico expressa por meio de manifestações culturais "não científicas":

Quadro 2 - Termos e referências à bomba atômica lançada sobre o Japão, em 6 de agosto de 1945, presentes no poema Rosa de Hiroshima e na letra de Enola Gay

\begin{tabular}{|c|c|c|}
\hline Letra & Termos / Expressões & Referências \\
\hline $\begin{array}{l}\text { Rosa de } \\
\text { Hiroshima }\end{array}$ & $\begin{array}{l}\text { Crianças mudas } \\
\text { Meninas cegas } \\
\text { Rotas alteradas } \\
\text { Rosa sem perfume } \\
\text { Rosa radioativa }\end{array}$ & $\begin{array}{l}\text { Doenças causadas pela radiação } \\
\text { Destino e realidades sociais } \\
\text { mudadas pela necessidade de } \\
\text { reconstrução das cidades } \\
\text { Formato da nuvem gerada pela } \\
\text { explosão } \\
\text { Características e efeitos da radiação } \\
\text { expressos por figuras de linguagem }\end{array}$ \\
\hline Enola Gay & $\begin{array}{l}8 \mathrm{~h} 15 \\
\text { Little boy } \\
\text { Enola Gay } \\
\text { Mãe orgulhosa }\end{array}$ & $\begin{array}{l}\text { Horário do lançamento da bomba } \\
\text { sobre Hiroshima } \\
\text { Nome com o qual os militares } \\
\text { estadunidenses batizaram a bomba } \\
\text { de urânio } \\
\text { Nome dado ao avião B-29 que } \\
\text { lançou a bomba de urânio sobre } \\
\text { Hiroshima } \\
\text { O avião tem o mesmo nome que a } \\
\text { mãe do piloto do B-29 } \\
\text { Linguagem figurativa em alusão aos } \\
\text { males de longa duração causados } \\
\text { pela bomba atômica }\end{array}$ \\
\hline
\end{tabular}

Fonte: Elaborado pelos autores.

Ao conduzir a atividade nesses moldes, o docente permite aos seus alunos o contato e a compreensão de termos e fatos relacionados a um importante episódio histórico a partir de outras perspectivas, diferentes da tradicional apresentação 
de informações técnicas, como é comum em livros didáticos e paradidáticos. Ou seja, muda-se o foco: em vez de a ciência contar sua própria história, é a sociedade, por meio de seus diversos interlocutores, que apresenta sua versão acerca do impacto da ciência em seu cotidiano e em sua dinâmica de existência e sobrevivência.

O Quadro 3 apresenta, a seguir, os conteúdos programáticos de física para o ensino médio que podem ser contemplados no contexto dessas atividades, as ferramentas e atividades didáticas sugeridas para o desenvolvimento dos temas e, também, algumas estratégias didáticas mobilizadas ${ }^{9}$.

Quadro 3 - Conteúdos programáticos de física que podem ser trabalhados, a partir das respectivas ferramentas e atividades didáticas sugeridas, e estratégias didáticas mobilizadas nas atividades

\begin{tabular}{|c|c|c|}
\hline $\begin{array}{l}\text { Conteúdos } \\
\text { Programáticos }\end{array}$ & $\begin{array}{l}\text { Ferramentas e Atividades } \\
\text { Didáticas Sugeridas }\end{array}$ & $\begin{array}{l}\text { Estratégias } \\
\text { Didáticas }\end{array}$ \\
\hline \multirow[t]{2}{*}{$\begin{array}{l}\text { Fontes de Energia } \\
\text { Transformações } \\
\text { Energéticas }\end{array}$} & $\begin{array}{l}\text { 1) Documentários Projeto Manhattan } \\
\text { e Luz Branca, Chuva Negra: discussões } \\
\text { reafirmando a possibilidade de } \\
\text { existirem diferentes leituras a respeito } \\
\text { de um mesmo episódio histórico, } \\
\text { baseadas em narrativas guiadas } \\
\text { por pontos de vista, interesses e } \\
\text { influências culturais distintas }\end{array}$ & $\begin{aligned} \checkmark & \text { Abordagem } \\
& \text { Ciência, Tecnologia } \\
& \text { e Sociedade (CTS) } \\
\checkmark & \text { Recursos } \\
& \text { audiovisuais } \\
\checkmark & \text { História e Filosofia } \\
& \text { da Ciência (HFC) }\end{aligned}$ \\
\hline & $\begin{array}{l}\text { 2) Poesia (Rosa de Hiroshima) e } \\
\text { Música (Enola Gay): leitura crítica das } \\
\text { letras de duas formas de se expressar, } \\
\text { por meio da literatura e da arte, a } \\
\text { contrariedade, a consternação e a } \\
\text { preocupação com os resultados da } \\
\text { Ciência }\end{array}$ & $\begin{array}{l}\checkmark \text { Abordagem } \\
\text { Ciência, Tecnologia } \\
\text { e Sociedade (CTS) } \\
\checkmark \text { Interface Arte e } \\
\text { Ciência } \\
\checkmark \text { História e Filosofia } \\
\text { da Ciência (HFC) }\end{array}$ \\
\hline
\end{tabular}

Fonte: Elaborado pelos autores.

9 Para a identificação dos conteúdos programáticos, utilizamos como referências: 1) As Orientações Complementares aos Parâmetros Curriculares Nacionais (PCN+: Ensino Médio) (BRASIL, 2002); e 2) Os conteúdos programáticos discriminados nos sumários de algumas coleções aprovadas na mais recente edição do Guia do PNLD - 2015 (BRASIL, 2014). 


\section{Considerações finais}

Sob o olhar da história da ciência, o professor de ciências do ensino médio tem a prerrogativa de propor e sustentar, em situações didáticas, discussões que transcendam os limites de um aprendizado acrítico de conteúdos científicos meramente fundamentados na memorização. Encarada no contexto do ensino de ciências como uma estratégia didático-pedagógica, a história da ciência apresenta-se como provedora de um grande manancial de episódios a serem explorados pelos docentes, desde que sejam observados e respeitados os contemporâneos critérios historiográficos coerentes com seus objetivos educacionais.

Outros relevantes recursos podem ser mobilizados para viabilizar o desenvolvimento da abordagem histórica, buscando oferecer mais sentido e eficácia para as ações adotadas. Este trabalho apresenta a possibilidade de discussão de temas relacionados a um importante conteúdo da física moderna e contemporânea, por meio de recursos audiovisuais e de composições artísticas (poesia e música), devidamente integrados à apresentação de um episódio histórico abordado a partir de um viés historiográfico atual.

Ao explorar fatos históricos utilizando recursos que vão além do texto escrito, o professor pode caracterizar o contexto sociocultural relacionado à exploração de determinados fenômenos físicos sem se limitar a argumentos exclusivamente teórico-experimentais. Assim, abre-se espaço - parafraseando as recomendações presentes em diversos documentos oficiais que orientam o ensino no Brasil - para a efetiva promoção de uma educação científica verdadeiramente crítica, ativa e transformadora. 


\section{Referências}

ARROIO, Agnaldo; GIORDAN, Marcelo. O Vídeo Educativo: Aspectos da Organização do Ensino. Química Nova na Escola, n. 24, p. 8-11, 2006.

BALDINATO, José Otávio; PORTO, Paulo Alves. Variações da história da ciência no ensino de ciências. In: ENCONTRO NACIONAL DE PESQUISA EM EDUCAÇÃO EM CIÊNCIAS - ENPEC, 6., 2008, Belo Horizonte. Anais eletrênicos... Belo Horizonte: ABRAPEC, 2008. Disponível em: <http://www.nutes.ufrj.br/ abrapec/vienpec/autores0.html>. Acesso em: 5 jul. 2016.

BRASIL. PCN+ Ensino Médio: orientações educacionais complementares aos Parâmetros Curriculares Nacionais Ciências da Natureza, Matemática e suas Tecnologias. Brasília: MEC/SEB, 2002. Disponível em: <http://portal.mec.gov.br/seb/ arquivos/pdf/CienciasNatureza.pdf>. Acesso em: 11 jan. 2016.

BRASIL. Guia de livros didáticos: PNLD 2015 - Física. Brasília: MEC/SEB, 2014. Disponível em: <http://www.fnde.gov.br/ programas/livro-didatico/guias-do-pnld/item/5940-guiapnld-2015>. Acesso em: 11 jan. 2016.

BRASIL. Base Nacional Comum Curricular. Brasília: MEC/SEB, 2015.

CARVALHO, Ana Amélia Amorim Soares de. Utilização e exploração de documentos audiovisuais. Revista Portuguesa de Educação, v. 6, n. 3, p. 113-121, 1993.

LUZ BRANCA/Chuva Negra: A Destruição de Hiroshima e Nagazaki. 2011. 1 post (1h 25 min 37 s). Postado em: 20 dez. 
2011. Disponível em: <https://www.youtube.com/watch?v=-p1ZVMOUjw>. Acesso em: 22 maio 2012.

MORÁN, José Manuel. O vídeo na Sala de Aula. Comunicação \& Educação, v. 1, n. 2, p. 27-35, 1995. Disponível em: <http:// www.revistas.usp.br/comueduc/article/view/36131>. Acesso em: 11 jan. 2016.

ORCHESTRAL MANOEUVERS IN THE DARK. OMC Live at the Museum of Liverpool Trailler. 1 post. (1 min 37 s). Postado em: 2 jun. de 2015. Disponível em: <http://www.omd.uk.com/video/ enola_gay_live $>$. Acesso em: 17 jan. 2016.

PORTO, Paulo Alves. História e Filosofia da Ciência no Ensino de Química: em busca dos objetivos educacionais da atualidade. In: SANTOS, Wildson Luiz Pereira dos; MALDANER, Otavio Aloisio (Org.). Ensino de Química em Foco. ljuí: Editora Unijuí, 2010. p. 159-180.

REZENDE, Luiz Augusto. História das Ciências no ensino de Ciências: contribuições dos recursos audiovisuais. Ciência em Tela, v. 1, n. 2, p. 1-6, 2008.

SCHMIEDECKE, Winston Gomes. A história da ciência nacional na formação e na prática de professores de física. 2016. Tese (Doutorado em Ensino de Ciências) - Programa de Pós-Graduação Interunidades em Ensino de Ciências, Universidade de São Paulo, São Paulo, 2016.

.; PORTO, Paulo Alves. Uma abordagem da história da energia nuclear para a formação de professores de física. Revista Brasileira de História da Ciência, v. 7, n. 2, p. 232-241, 2014.

.; TADEU NETO. Kleber. Licenciandos em Física e a História e Filosofia da Ciência enquanto abordagem didático-pedagógica. 
In: SIMPÓSIO NACIONAL DE ENSINO DE FÍSICA - SNEF, 21., 26-30 jan. 2015, Uberlândia. Anais eletrônicos... Uberlândia: UFU, 2015. Disponível em: <http://www.sbf1.sbfisica.org.br/eventos/ snef/xxi/sys/resumos/T0557-1.pdf/>. Acesso em: 5 jul. 2016.

YOUTUBE Modern Marvels - Manhattan Project (episode 21, season 9), 2002. Disponível em: <https://www.youtube.com/ watch?v=8kFr5zTxsUM>. Acesso em: 03 out. 2016.

YOUTUBE Maravilhas Modernas Projeto Manhattan Parte 1 File2HD com. 2011a. 1 post (9 min 33 s). Postado em: 15 jun 2011. Disponível em: <https://www.youtube.com/watch?v=OvqdeYcGs O8\&list=PL501D421C1E823A43>. Acesso em :15 jan. 2016.

YOUTUBE Maravilhas Modernas Projeto Manhattan Parte 2. 2011b. 1 post. ( 8 min 39 s). Postado em: 15 jun 2011. Disponível em: <https://www.youtube.com/watch?v=rQHeEE_8gbw\&list= PL501D421C1E823A43\&index=3>. Acesso em: 15 jan. 2016.

YOUTUBE Maravilhas Modernas Projeto Manhattan Parte 3b File2HD com. 2011c. 1 post (9 min. 11 s). Postado em: 15 jun 2011. Disponível em: <https://www.youtube.com/watch?v=okz QS8c6bBA\&index=4\&list=PL501D421C1E823A43>. Acesso em: 15 jan. 2016.

YOUTUBE Maravilhas Modernas Projeto Manhattan Parte 4 File2HD com. 2011d. 1 post (8 min. 52 s). Postado em: 15 jun 2011. Disponível em: <https://www.youtube.com/watch?v=0IHHPKIYpQ\&list=PL501D421C1E823A43\&index=5>. Acesso em: 15 jan. 2016. 


\section{A BUSCA DE DIÁLOGOS ENTRE CIÊNCIA E ARTE COMO FORMA DE CONSTRUIR CAMINHOS DE COMPREENSÃO DO PENSAMENTO CIENTÍFICO}

José Cláudio Reis

Andréia Guerra

Marco Braga

\section{Introdução}

Os novos problemas da Ciência, os novos resultados das diferentes áreas científicas e os financiamentos científicos estão diariamente presentes nos noticiários. Vivemos numa sociedade em que as questões científicas permeiam nossas vidas, sendo a Ciência ${ }^{1}$ atualmente um fator fundamental a ser considerado pelos cidadãos quando esses discutem questões de políticas públicas, ou mesmo quando tratam de questões de cunho mais

\footnotetext{
1 Iremos usar o termo Ciência no singular e não o termo Ciências no plural. Tomamos o termo no singular por reconhecermos que apesar das diferenças metodológicas entre as diferentes Ciências - como Botânica, Ciências da Saúde, Física de Partículas, Cosmologia, Geologia etc. -, podemos considerar que todas elas têm uma unicidade no que tange ao tipo de questões que constroem e respondem sobre a natureza.
} 
pessoal. Essa peculiaridade de nossos dias indica que pensar a Ciência é algo importante para atuação dos cidadãos na sociedade. Afinal, como se constituiu esse conhecimento que tanto se faz presente em nossa vida?

Para entendermos como a Ciência se constituiu ao longo da história e como a mesma assumiu o papel desempenhado na sociedade contemporânea, é importante tomarmos o conceito de Cultura. Geertz (1978) desenvolve tal conceito a partir do olhar de Weber, ${ }^{2}$ considerando que os homens e as mulheres são animais ligados a uma rede de significados que eles próprios constroem. A partir desse referencial, consideramos que a Ciência, enquanto um empreendimento social construído por homens e mulheres imersos num tempo e espaço específicos, faz parte da Cultura das sociedades contemporâneas. Isso implica que esse conhecimento é construído a partir da interação de homens e mulheres na estrutura socioeconômica em que se situam, refletindo questões socioculturais desse contexto. O conhecimento científico, no entanto, não apenas reflete o contexto sociocultural no qual foi e é construído, mas também refrata tal contexto, de forma que a Ciência, por ser co-constituinte do contexto sociocultural em que está inserida, interfere nesse contexto.

Essas considerações nos levam a defender que, para compreendermos como a Ciência se constituiu, é preciso considerar questões que ultrapassam o mundo científico estrito, destacando os diálogos estabelecidos entre os construtores desse conhecimento e o contexto sociocultural em que estavam

\footnotetext{
2 Em Weber a cultura é um campo de conflitos sociais onde os indivíduos medem forças para terem seus valores e crenças aceitos.
} 
imersos (HENDERSON, 2008). Com vistas a contribuir para reflexões em torno a esses diálogos, esse capítulo tem por objetivo apresentar resultados de um estudo realizado a respeito do desenvolvimento da física e das artes plásticas ao longo de três períodos históricos: parte do período medieval, o Renascimento e a segunda metade do século XIX.

A seleção desses períodos ocorreu porque, na construção do estudo em torno aos diálogos estabelecidos entre artistas e cientistas, esses três movimentos apontaram questões significativas para a construção de subsídios para reflexões em torno ao processo de construção da Ciência.

É importante ressaltar, entretanto, que os diálogos entre física e artes plásticas não podem ser pensados de forma estreita, tentando estabelecer relações de influência entre estes campos (REIS; GUERRA; BRAGA, 2006). O estudo empreendido apontou que é importante ultrapassar análises de influência de um sobre o outro e considerar que diálogos diretos e indiretos estabeleceram cientistas e artistas na leitura e construção de conhecimento sobre o mundo nos mesmos períodos históricos (MILLER, 1996). Dessa forma, busca-se discutir a cultura em que esses artistas e cientistas encontravam-se imersos e como eles refletiram e refrataram essa cultura na construção de seus trabalhos. Por exemplo, ao discutirmos o movimento impressionista do século XIX e a Física ali desenvolvida, estaremos centrando a análise não nos conhecimentos científicos sobre luz e cor usados pelos artistas para comporem suas obras, mas nos caminhos que eles e os cientistas, através da cor e da luz, trilharam para responder problemas de seu tempo e espaço (SCHAPIRO, 2002). 


\section{O espaço medieval e renascentista}

Nessa seção, traremos algumas ponderações a respeito do movimento artístico do Renascimento, advindo com a introdução da técnica da perspectiva nas artes plásticas. Para tal, serão necessárias algumas considerações a respeito da arte medieval, pois será a partir do contraponto da arte renascentista com a arte medieval, que construiremos nossos argumentos.

As pinturas medievais se caracterizaram em grande medida por apresentarem temas bíblicos e por representarem as cenas em espaços fechados e hierarquizados. Isso não significou que os cenários escolhidos eram sempre próprios de ambientes fechados. O espaço era representado fechado, mesmo quando a cena descrita ocorria em locais abertos, como uma cena no campo, por exemplo. O episódio bíblico do nascimento de Jesus na manjedoura pintado por Duccio Buoninsegna de Siena (1308-1311) representa bem essas características. O céu é representado de forma completamente distinta da Terra. O céu se apresenta em dourado e inalcançável, não por que ele se apresente dourado na cena registrada, mas porque representa a morada de Deus, o céu perfeito, que deve ser colocado em sua essência como os maiores requisitos de perfeição. Outra questão presente nessa pintura foi a hierarquização social das pessoas representadas, registrada no tamanho em que a pessoa era retratada. Ao compararmos o tamanho em que Maria foi representada com aquele em que os animais o foram, percebemos que a proporção não correspondia àquela encontrada no cotidiano. Os tamanhos dos personagens presentes equivaliam ao valor social desses personagens na cena. O espaço ali destacado não era concebido como homogêneo ou isotrópico. 


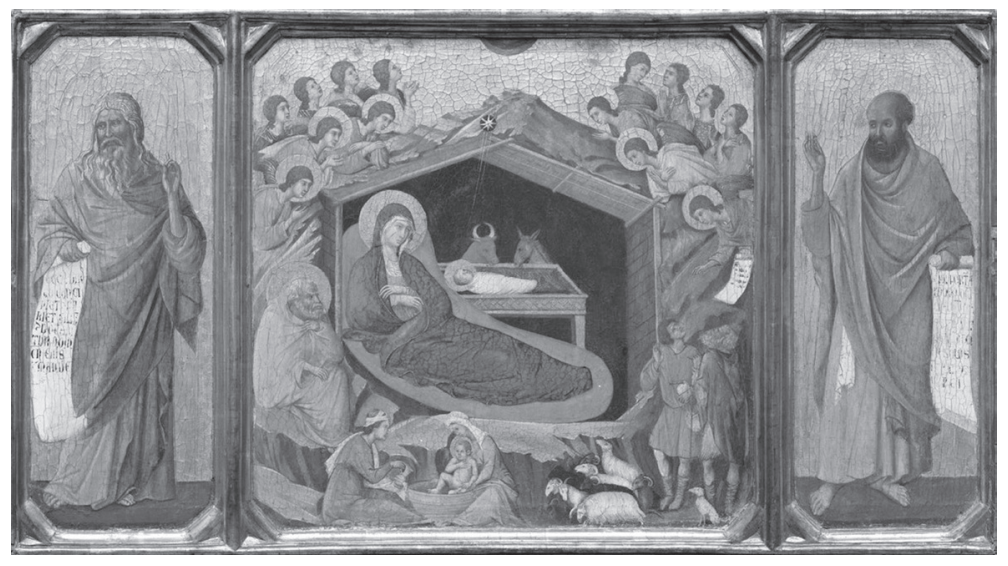

Figura 1 - Natividade com os profetas Isaías e Ezequiel (1308-1311).

Fonte: National Galery of Art, Washington.

Quando analisamos outras pinturas medievais, percebemos características similares. Na pintura da última ceia feita por Ugolino de Siena (c1280-1349), por exemplo, Jesus ocupa uma das cabeceiras da mesa e seu tamanho é maior do que de qualquer um dos outros personagens retratados, inclusive daquele que ocupa a outra cabeceira. Todos os personagens foram representados em tamanhos tais que não é possível considerá-los em pé naquele cenário. Representações espaciais como essas são encontradas em obras de inúmeros outros artistas medievais, como Giovanni Cimabue (c1240-1302), entre tantos outros.

Essa representação pictórica espacial, que preencheu as paredes dos mosteiros, igrejas medievais entre outros locais, estava de acordo com a concepção espacial da Ciência medieval. Da mesma forma que nas artes plásticas, o espaço científico era percebido como hierarquizado, fechado e finito. Tanto as artes plásticas como a Ciência refletiram em suas teorias e 
representações pictóricas este caráter que teve fundamental importância para criar uma cosmogonia sobre o funcionamento da natureza coerente com o contexto sociocultural daquele tempo e espaço.

A Ciência medieval, com forte influência de Aristóteles (384 a.C.-322 a.C.) e Ptolomeu (90 d.C.-168 d.C.), construiu uma visão espacial a partir da diferenciação entre o mundo terrestre (sublunar) e o mundo celeste (supralunar). O mundo terrestre, o sublunar, era o mundo da transformação, da corrupção e da mudança, aquele em que poderia haver nascimento, vida e morte. O mundo celeste, o supralunar, era o mundo da permanência, da perfeição e da imutabilidade. Esse era um universo dicotômico, no qual as explicações para os acontecimentos nos dois mundos eram concebidas como diferentes.

O movimento dos corpos no mundo sublunar, por exemplo, era explicado a partir de sua constituição e do lugar natural em que os elementos constitutivos do corpo deveriam ocupar. Todos os corpos do mundo sublunar eram concebidos como constituídos de quatro elementos: terra, água, ar e fogo. Cada um desses elementos tinha um local natural específico, no qual ficariam em eterno repouso. Dentro dessa consideração, o movimento sublunar poderia ser de duas formas: natural ou violento. O movimento natural era vertical, podendo ser no sentido da Terra ou contrário a esse sentido; o que definia o movimento ser para cima ou para baixo era a constituição do corpo, visto que o movimento do corpo ocorria para que o mesmo retornasse ao seu lugar natural. O movimento violento ocorria quando algum agente externo ao corpo o obrigava a movimentar-se, mas seu comportamento, também, guardava relação com sua constituição. No caso do mundo supralunar, os movimentos eram sempre naturais, porém os corpos celestes eram constituídos do elemento éter e não seguiam a lógica dos movimentos 
naturais do mundo sublunar, o movimento no mundo supralunar era sempre circular e com velocidade constante.

A astronomia ptolomaica estava ancorada nessa física, na qual um sistema geostático era coerente com a divisão de mundo sub e supralunar e adequado às tabelas astronômicas conhecidas, contendo boa capacidade de previsão de fenômenos terrestre e celestes (BRAGA; GUERRA; REIS, 2004a, 2004b).

A Física e a pintura medievais imersas em uma mesma cultura falam de um mesmo espaço. Dessa forma, interpretavam e representavam o mundo a partir de uma concepção na qual a hierarquia, seja social ou posicional dos corpos no espaço, estava bem representada e essas representações social e posicional eram coerentes entre si. Por exemplo, ao retirarmos da cena da última ceia, representada por Ugolino de Siena e citada anteriormente, a figura de Jesus, o espaço representado muda completamente. Isto porque, naquela pintura, outro personagem que ocupasse a cabeceira não teria a mesma representação pictórica, pois o tamanho atribuído a Jesus não correspondeu ao local que ele ocupava na cena, mas ao seu papel social. Assim, por ter maior valor social, ocupou um tamanho diferenciado no local a ele atribuído. Se ele fosse substituído naquele local por outro personagem da cena, o mesmo seria retratado num tamanho diferenciado ao da primeira situação. De forma análoga, os corpos que compunham o Universo não podiam ocupar qualquer lugar no espaço e não podiam apresentar qualquer tipo de movimento. Existia uma hierarquia que não deveria ser quebrada, sob o risco de desmoronar toda uma estrutura que suportava as explicações desse período.

Vale ressaltar que, em um universo como esse, não era fácil pensar em movimentos que durassem eternamente, pois os corpos naquele espaço fechado e hierarquizado não podiam ocupar qualquer local. Por exemplo, a um corpo terrestre não 
poderia ser atribuída a possibilidade de mover-se indefinidamente em linha reta através do espaço, pois, em algum momento, ele tocaria a fronteira entre o mundo sublunar e supralunar e, como esse corpo não podia ocupar o mundo além da esfera da Lua, ele não poderia ultrapassá-la para seguir o movimento eterno. De forma análoga, a representação pictórica, também, não permitia que diferentes personagens ocupassem quaisquer posições nas cenas retratadas, pois, do contrário, haveria uma transgressão do mundo hierarquizado.

Essa visão espacial, muito bem representada no mundo das Ciências e nas artes plásticas, sofreu abalos. A Europa medieval não foi um corpo coeso. A invasão dos árabes na Península Ibérica e a reconquista dessas terras pelos reis cristãos trouxeram ao europeu o encontro de livros de Aristóteles e outros filósofos ainda não conhecidos na Europa. Fora isso, essa presença árabe colocou os europeus em contato com novas técnicas, que alteraram aquele cotidiano, trazendo novos olhares para o estudo da natureza (BENOIT; MICHEAU, 1998). Esses novos conhecimentos introduzidos, principalmente a partir do século XII, coincidiram com mudanças no seio da Igreja Medieval. Nesse processo, houve o surgimento de novas ordens religiosas, como a dos franciscanos, que trouxeram novas considerações sobre a hierarquia do clero, sobre a riqueza do clero e sobre o pensar o mundo, que se traduziram em novas representações espaciais (ROSSI, 1992).

Giotto (1267-1337) e sua escola são importantes para entender esse contexto. As pinturas produzidas na escola de Giotto trouxeram algo novo em relação às pinturas medievais, rompendo com a representação dourada e, portanto, perfeita para o céu (BRAGA; GUERRA; REIS, 2004a, 2004b). O céu passou a ser, por eles, representado como azul. Há pinturas, como a 
Adoração dos Reis Magos (1304-1306), em que, além de o céu estar azul, nele foram representados objetos. Nessa pintura, por exemplo, há a representação de um cometa no céu azul. Essa é uma novidade trazida por aquela escola, para aquele contexto. Nas pinturas em que o céu se apresentava dourado, não eram colocados objetos no céu, o dourado se mostrava homogêneo, assim como o mundo supralunar era percebido.

Ao apreciarmos Giotto, já estamos nos aproximando do início do período reconhecido como Renascimento, que marcou transformações nas representações pictóricas e explicações do universo. Podemos considerar que Giotto e sua escola protagonizaram uma transição nas artes plásticas entre o medievo e o Renascimento ao colocar o universo ao alcance dos homens (OSTROWER, 1998). Autores como Ostrower (1998) defendem que Giotto e sua escola foram importantes para o início de uma mudança de representação espacial. Por terem tido uma produção significativa, impulsionaram mudanças não apenas na forma de representar, mas na forma de se pensar o espaço, abrindo caminhos para o surgimento da perspectiva renascentista.

A invenção da perspectiva surgiu num contexto de questionamento da ordem estabelecida e de busca de novos caminhos para construir explicações sobre o mundo ao nosso redor. Esse contexto estava imerso num mundo em que os europeus tomavam conhecimento de novas técnicas, novas terras eram por eles atingidas e novos povos conhecidos. Nesse mundo em que os horizontes se expandiam, tanto artistas plásticos quanto filósofos naturais experimentaram novas possibilidades de respostas aos questionamentos de seu tempo (BRAGA; GUERRA; REIS, 2004a, 2004b). Artistas, como Bruneleschi (1377-1446), Leonardo da Vinci (1452-1519), Raphael (1483-1520), Michelangelo (1475-1564), construíram obras em que a dicotomia entre céu e Terra e a hierarquização e finitude do espaço deixaram de 
ser representadas. Suas obras apresentaram um espaço infinito, homogêneo e isotrópico.

Essa nova forma de interpretar e representar o espaço invadiu o cotidiano dos italianos que viviam nos ambientes em que a nova arte era apresentada. Nesse novo cotidiano, em que conviviam pinturas com representações espaciais distintas, filósofos naturais concebiam novas teorias para o movimento dos corpos terrestres e celestes diferentes das comumente ensinadas. O velho e novo estavam no mesmo espaço geográfico, disputavam lugar. As mudanças não vinham sem abalar certezas, sem questionamentos. O processo de mudança foi complexo. O italiano Giordano Bruno (1548-1600), por exemplo, defendeu ser o Universo infinito. Suas proposições, imersas num mundo em transformação, foram consideradas hereges, o levando à condenação pela Inquisição.

A nova técnica da perspectiva extrapolou o mundo das artes plásticas, não se fazendo apenas presente nas obras construídas pelos artistas. Essa técnica não foi apenas ensinada aos artistas. No século XVI, a técnica era cada vez mais divulgada para profissionais de outras áreas, especialmente na Itália e Alemanha, porém, no caso da Alemanha, não havia o interesse pelas artes visuais como na Itália (EDGERTON, 1991).

Na Itália, vários livros de técnica de perspectiva eram publicados. Geômetras, matemáticos, artistas, entre outros, dedicavam-se ao tema. Problemas referentes a técnicas de claro e escuro e às possibilidades de desenhar uma esfera com protuberâncias eram debatidos naquele contexto (EDGERTON, 1991). Essa disseminação fez com a perspectiva assumisse uma importância singular nas representações visuais nos diferentes campos, como nos projetos de arquitetura e na astronomia. 
Florença foi uma cidade particular no desenvolvimento e disseminação da técnica da perspectiva. A formação intelectual de Galileu Galilei (1564-1642) teve a marca de Florença. Em 1562, foi fundada na localidade a Accademia del Disegno (Academia do Desenho), uma organização, na qual pintores, escultores e arquitetos encontravam-se para estudar e discutir não apenas questões artísticas, mas como intelectuais discutiam questões científicas, filosóficas e literárias (EDGERTON, 1991). Um dos objetivos da Accademia era atualizar os artistas nas Ciências consideradas fundamentais às artes visuais: a geometria e a anatomia. Galileu não esteve ausente desses debates, e, em 1613, ele ingressou na Accademia (EDGERTON, 1991).

Para os objetivos desse capítulo, é importante pontuar um acontecimento do ano de 1609 . Nessa data, dois astrônomos, em dois locais distintos, e por isso com formações acadêmicas distintas, realizaram um ato não corriqueiro no mundo da filosofia natural da época: utilizaram lunetas para observar astros celestes. Com suas lunetas, observaram a Lua. Suas lunetas eram similares tecnicamente e esse era um instrumento conhecido naquele contexto (EDGERTON, 1991). Porém, apontar a luneta para o céu foi um ato novo feito por esses filósofos naturais no mesmo ano. Os dois utilizaram a luneta para observar a Lua, um astro celeste que, na filosofia aristotélica, era percebido como uma esfera perfeita. No mundo cristão, usava-se, por exemplo, a metáfora: a Virgem Imaculada Conceição era "pura como a Lua". Nas representações pictóricas, a Imaculada Conceição era posicionada em pé sobre a Lua.

Apesar de estarem no mesmo tempo, Harriot e Galileu viviam em contextos socioculturais distintos. Na Inglaterra de Harriot, Francis Bacon havia defendido uma posição contrária à filosofia aristotélica em relação à Lua. Ele a considerou um corpo 
não sólido, composto de algum tipo de vapor (EDGERTON, 1991). Não temos registros de qual era o olhar de Harriot para a Lua, porém sabemos que, ao posicionar seu instrumento, a luneta, para o céu, esse filósofo natural não conhecia a técnica da perspectiva e, portanto, não dominava a técnica do claro e escuro ou a representação de uma esfera com protuberâncias (EDGERTON, 1991). Um livro descrevendo em detalhes a técnica de perspectiva e com a proposta de ensinar representações desse tipo somente foi publicado na Inglaterra em 1635. Harriot, ao retratar a Lua pela primeira vez, desenhou a linha de demarcação entre as partes iluminadas e sombreadas da Lua, com movimentos irregulares curtos, sem perspectiva, mas como se os mesmos estivessem em uma superfície rugosa (EDGERTON, 1991).

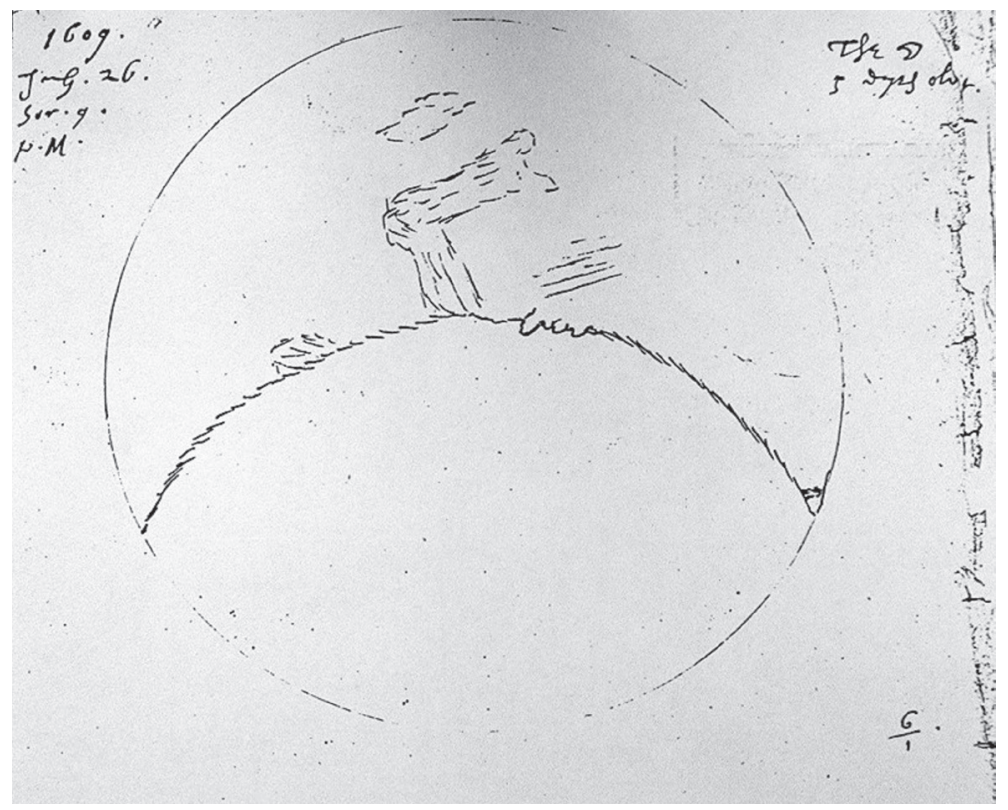

Figura 2 - Lua representada por Harriot (1609)

Fonte: Edgerton (1991) 
Galileu, ao contrário, ao posicionar a luneta para Lua, dominava a técnica de claro e escuro, conhecia os debates da época sobre as técnicas de perspectiva, sobre as representações pictóricas de esferas com protuberâncias. Galileu observou, então, a Lua, a partir de seus conhecimentos de perspectiva. Interpretou claros e escuros como sombras projetadas, resultados da presença de crateras e montanhas na superfície da Lua.
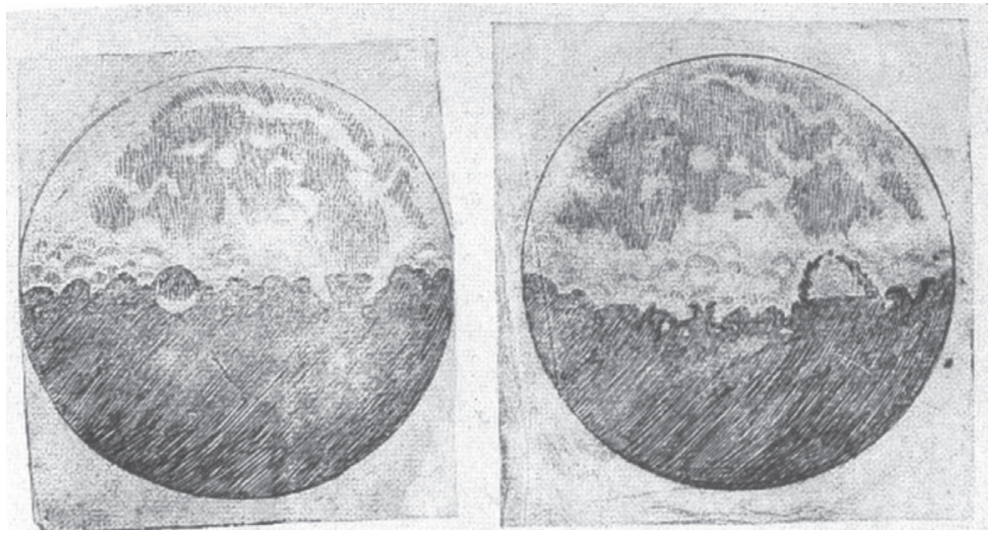

Figura 3 - Lua representada por Galileu (1609)

Fonte: Edgerton (1991)

Importante aqui destacar que tanto Harriot quanto Galileu, com o instrumento usado, não podem ter observado a Lua com muita nitidez. Eles apenas conseguiam ver um quarto da superfície da Lua por vez, mesmo assim os dois se dedicaram a representar o astro. Por estarem em contextos culturais distintos, registraram imagens distintas e seguiram caminhos diferentes. Galileu, além de fazer desenhos das observações da superfície da Lua, realizou cálculos geométricos, para determinar a altura das montanhas que registrou. Além disso, utilizou seus dados para orientar a construção dos desenhos da superfície da 
Lua a serem publicados, no ano de 1610, no livro por ele escrito e intitulado "O Mensageiro das Estrelas". Interessante destacar que, em 1610, apenas quatro meses após a publicação do livro de Galileu, Thomas Harriot fez um novo desenho da superfície da Lua. Se compararmos as imagens produzidas por Harriot em 1610 com aquelas do livro de Galileu, veremos que os círculos e semicírculos desenhados pelo filósofo natural inglês guardavam semelhanças com aqueles apresentados no livro de Galileu (EDGERTON, 1991).
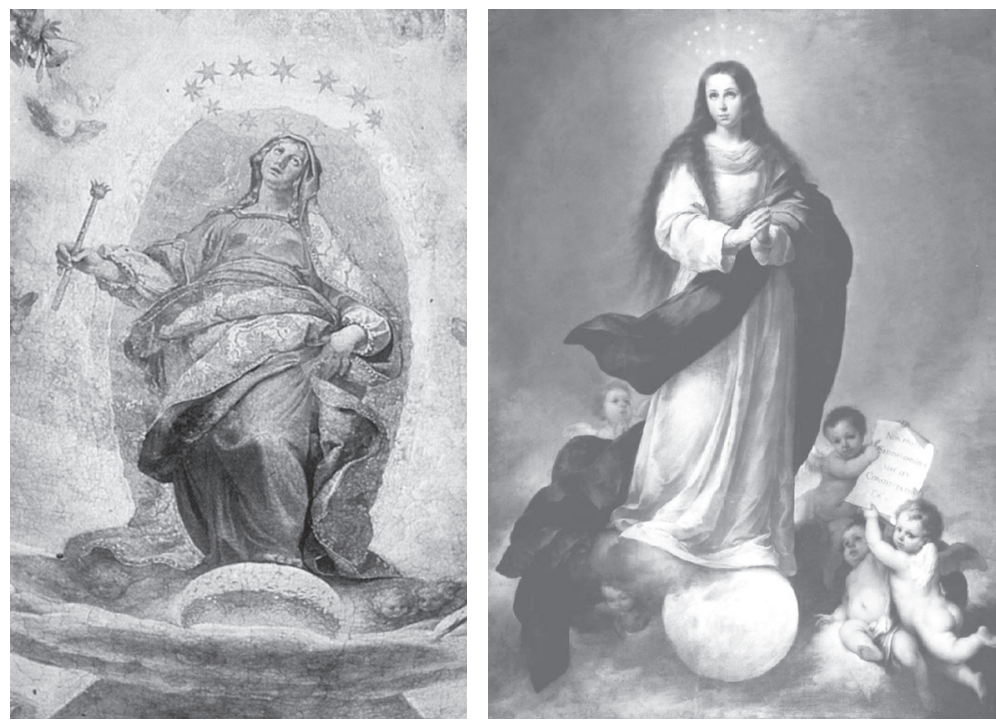

Figura 4 - À esquerda a Imaculada de Cigoli e à direita a Imaculada de Murillo.

Fonte: Cigoli, afresco da Igreja de Santa Maria Maggiore, Roma e Murillo, Walters Art Museum, Baltimore.

Da mesma forma que a perspectiva não ficou restrita às artes, as observações de Galileu não foram consideradas apenas pelos filósofos naturais. Três anos depois dos desenhos feitos 
por Galileu, Cigoli (1559-1613), amigo de Galileu, pintou um afresco na Igreja Santa Maria Maggiore, em Roma, que intitulou Ascensão. Ao representar a Concepção da Virgem Maria, Cigoli, nesse afresco, inspirado nos desenhos feitos por Galileu, pintou a Lua com crateras. Num local sagrado, as crateras da Lua de Galileu foram representadas.

Cigoli não apenas retratou a Lua de Galileu em sua pintura, ele deu assistência ao filósofo natural italiano quando o mesmo foi registrar as observações da superfície do Sol. Galileu contou com a ajuda de Cigoli para decidir se as manchas solares observadas estariam dentro do Sol ou além dele, circulando como um satélite. Foram desenhos feitos por Cigoli para representar as duas situações que auxiliaram Galileu na decisão final (EDGERTON, 1991).

As novidades trazidas por homens como Galileu e Cigoli povoaram um mundo em transformação, num contexto sociocultural italiano no qual as novas técnicas eram difundidas e novos estudos estabelecidos (ROSSI, 1992). Esse não foi um movimento que ocorreu de forma homogênea na Europa. As mudanças não ocorreram de forma instantânea. Se tomarmos a pintura feita pelo espanhol Bartolomé Esteban Murillo (16171682), em 1660, perceberemos que essa não foge dos preceitos do mundo cristão, retratando a Virgem Maria em pé sobre a Lua, mas não a Lua representada por Galileu, mas uma Lua esférica e perfeita. A Lua pintada por Murillo não é chapada na superfície, tem volume como a de Cigoli, porém sua superfície não contém crateras. Os processos de mudança e de difusão do novo são complexos. Não se constrói o novo sem o passado e não se destrói o passado instantaneamente com a construção do novo.

Ainda na construção do diálogo entre o velho e o novo, é importante destacar que as imagens dos corpos celestes construídas por Galileu, além de estabelecerem um novo olhar para 
aqueles astros, compuseram, com as outras obras do autor, uma proposta de como estudar o Universo distante daquela proposta por Aristóteles. Sua obra correspondeu a um mundo observável, como o de Aristóteles, porém agora sujeito à medição. Os conhecimentos de geometria e perspectiva não estiveram figurados apenas nas representações pictóricas por ele realizadas, elas extrapolaram o mundo da imagem e impulsionaram a construção de uma concepção de espaço geométrico e de um movimento que não ocorria para cumprir uma finalidade. $O$ estudo do movimento, assim como o do espaço, estava com Galileu geometrizado.

\section{Encontrando outro tempo e espaço: o século XIX}

O segundo recorte escolhido para compor esse capítulo é o século XIX, mais precisamente o período correspondente aos movimentos impressionista e fauvista. Assim como a técnica da perspectiva foi fundamental para a construção de uma nova concepção espacial nas artes plásticas e na Ciência do século XVI, a invenção da câmara fotográfica impactou, no século XIX, as artes plásticas e a Ciência. Esse novo equipamento permitiu o registro de cenas a partir do congelamento do tempo do ocorrido e, como a câmara escura do século XVII, possibilitou registros espaciais com aparente fidedignidade à perspectiva clássica, além de viabilizar a permanência desse registro. Com o novo equipamento era possível captar um instante da realidade da mesma forma que a perspectiva clássica, porém com maior rapidez.

A perspectiva renascentista que com suas regras conseguia enganar o olhar, possibilitando a construção de um espaço 
homogêneo, isotrópico e infinito num plano bidimensional, terá na fotografia seu aliado fiel, tirando dos artistas a exclusividade dessa representação espacial. Isso acaba por trazer um problema para as artes plásticas, afinal qual seria, então, sua especificidade?

Respostas a essa questão se materializam na introdução de representações que aos poucos romperam com os preceitos da perspectiva renascentista. O movimento impressionista, representado por artistas como Édouard Manet (1832-1883), Claude Monet (1840-1926), Paul Cézanne (1839-1906), entre outros, cada um a seu modo, construiu novas possibilidades de representação espacial, em que a homogeneidade e isotropia do espaço da perspectiva renascentista não se fizeram mais presentes, uma vez que tempo e matéria passaram a ser considerados fundamentais para a caracterização espacial.

Manet, em seu quadro Le déjeuner sur l'herbe (Almoço na relva, 1862-63), propositalmente violou as leis da perspectiva na construção da cena representada. Nessa pintura, o plano da frente da cena está desconectado do plano dos fundos, eliminando uma possível região intermediária. A mulher que está se banhando no rio disposto ao fundo da cena é reproduzida num tamanho não condizente com as regras da perspectiva clássica, no propósito de perturbar o espectador (SHLAIN, 1991). Esse quadro contém uma construção espacial que viola as regras da perspectiva renascentista, mudando tacitamente a representação de acordo com o espaço euclidiano (SHLAIN, 1991).

Em outro quadro, La Musique aux Tuileries (Música nos jardins de Tuileries - 1862), Manet, também, introduziu elementos que produziram estranhezas em relação à perspectiva clássica. A falta de perpendicularismo dos troncos das árvores, sempre representados inclinados, e o fato do tronco central quebrar 
a profundidade da cena, ao interromper a horizontalidade, normalmente usada na técnica da perspectiva clássica para dar noção de profundidade, trouxe uma representação espacial não homogênea e não isotrópica para aquela cena.

Em outra perspectiva, o trabalho de Claude Monet trouxe uma possibilidade de diálogo entre o tempo e o espaço fazendo com que ele se tornasse o primeiro artista, desde o Renascimento, a investigar o tempo como uma dimensão espacial. Monet considerou que para criar a essência do objeto não bastaria representá-lo num tempo único, de forma congelada, como a fotografia representava os objetos. Era necessário ir além, indicando as mudanças, as novas impressões exercidas pelo objeto no sujeito com o passar do tempo. A partir de 1891, Monet começou a pintar a mesma cena repetidas vezes da mesma posição no espaço, mas em diferentes horas do dia ou épocas do ano. A sequência de pinturas da Cathédrale de Rouen (Catedral de Rouen - 1892) criou uma catedral que existia no tempo, tão bem quanto no espaço, em três dimensões. Um objeto se apresentava possuidor de duração temporal juntamente com as três dimensões do espaço (SHLAIN, 1991). O espaço não se apresentava independente do tempo, ambos passaram a integrar a arte de Monet. Isso representou, naquele contexto, uma novidade para as reflexões acerca dessas grandezas fundamentais. $O$ tempo e o espaço absolutos newtonianos não guardavam qualquer relação entre si.

Monet repetiu essa abordagem em outras séries que produziu, como a série Les Meules (Montes de Feno - 1888) e a série Le Parlement (Parlamento Inglês - 1900-1904). Nessas pinturas, o tempo foi um fator preponderante para expressar o espaço.

Paul Cézanne, outro representante do impressionismo, trouxe questões em torno das relações entre o espaço e a matéria. O espaço por ele representado deixou de ser considerado 
vazio. Ele produziu suas pinturas de forma tal que os objetos integravam o espaço. Ao retirarmos da cena qualquer um dos objetos retratados, o espaço muda completamente. Aquele espaço não homogêneo não é um cenário isotrópico, no qual os objetos são dispostos sem nele interferirem.

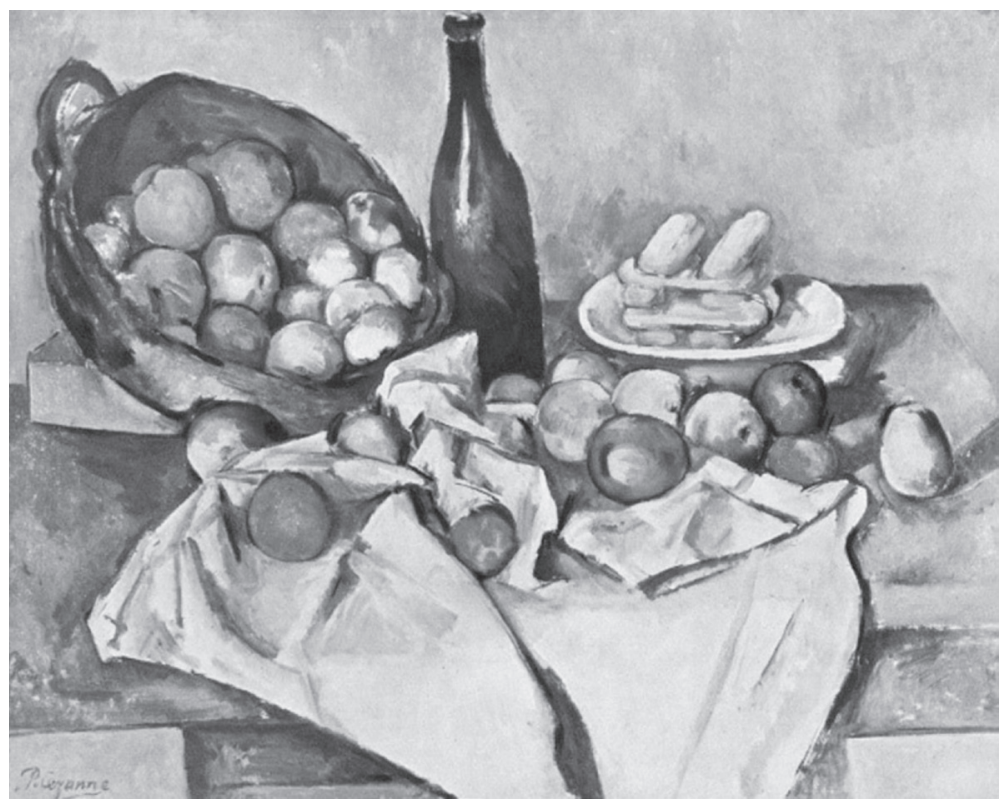

Figura 5 - Natureza Morta com Cesto de Maçãs (1895).

Fonte: Art Institute of Chicago.

Por séculos, artistas arrumaram os objetos sem afetar o espaço ao redor dos mesmos, como consequência o espaço não afetava o movimento nem era afetado por ele (SHLAIN, 1991). Podemos dizer o mesmo dos filósofos naturais newtonianos. Esses filósofos naturais pressupuseram um espaço homogêneo e isotrópico e um tempo absoluto que fluía independentemente desse espaço e dos objetos ali dispostos. 
Cézanne criou em suas obras uma multiplicidade de perspectivas, fazendo com que a representação espacial gerasse desconforto em um observador acostumado com a pintura de tradição renascentista. As naturezas mortas pintadas por Cézanne representam muito bem essas transformações. Nas obras de Cézanne, espaço e matéria possuíam implicações mútuas significativas, a ponto de perderem suas individualidades conceituais quando compreendidas de forma independente.

Em Nature morte aux pommes et bouteille (Natureza morta com cesto de maçãs - 1895), por exemplo, os objetos representados não são independentes do espaço, há uma interdependência que produz um diálogo (interação) entre espaço e objetos. Em várias outras pinturas de Cézanne pode ser observado esse diálogo.

Não apenas o espaço, o tempo, a matéria e suas relações são importantes para entendermos as modificações introduzidas no final do XIX. Ao pensarmos o papel que a cor passa a exercer na Ciência e nas artes plásticas, podemos entender a dimensão que ela desenvolverá em ambos os campos do conhecimento, construindo um panorama mais significativo das transformações ocorridas nesse período. Além da questão do espaço, tempo e matéria, os impressionistas colocaram em destaque a cor. Mesmo sem abandonar a figuração, eles atribuíram à cor maior importância do que aos objetos.

No início do século XX, os fauvistas (les fauves, "as feras") transformaram a cor numa nova essência do universo. A cor não poderia apenas ser compreendida a partir de grandezas físicas que associamos a ela. Para eles, não seriam seu comprimento de onda, frequência ou velocidade que a caracterizariam, mas sim sua interação subjetiva com o observador que definiria suas características.

Nesse novo caráter assumido pela cor, iniciado pelo Impressionismo, ampliado com os fauves, Paul Gauguin (1848- 
1903), por exemplo, usou as cores para manipular as emoções dos observadores, expressando intensamente a cor e simplificando a forma, em contraste com as regras dos pintores neoclássicos (SHLAIN, 1991). Gauguin criou uma nova linguagem para a cor, passando a concebê-la não mais como um fator absoluto, mas sim como algo relativo às interações com a sensibilidade do artista. Para os fauvistas, como Gaugin, as cores eram a própria pintura. Isso porque, para eles, mais importante do que os temas das pinturas eram os sentimentos que as cores poderiam produzir nos observadores (fruidores). As cores ganharam, assim, uma expressividade nova, sendo capazes de revelar sentimentos em quem contemplava estas obras.

A cor passou, na segunda metade do século XIX, a fazer parte do universo de artistas e cientistas como nunca antes. A Ciência com o aperfeiçoamento do espectroscópio por Bunsen e Kirchoff, em 1839, começou a extrair novos conhecimentos da cor. A cor passou a ser um indicador da presença de elementos num corpo. Por exemplo, através da análise da cor da luz oriunda de uma chama era possível aferir sobre os elementos dela constituinte. De forma similar, analisando a cor da luz advinda do Sol era possível falar sobre sua constituição.

Esse caminho, agora pavimentado em todos os seus aspectos, tanto científicos quanto artístico, permitiu, por exemplo, a análise do movimento das galáxias por Hubble (1889-1953) até que esse formulasse sua teoria sobre a expansão do universo. A cor passou a ser protagonista, tanto na pintura quanto na Ciência.

\section{Considerações finais}

Todo esse pano de fundo é rico para traçarmos um painel científico-cultural que nos permite uma apropriação mais 
rica das produções humanas ao longo da história. Ciência e arte, aqui representadas pela física e a pintura, ajudaram a construir o mundo que nos foi legado. Não são duas culturas independentes (SNOW, 1995), mas partes de uma mesma cultura.

Esse é um aspecto que devemos ressaltar, entender a Ciência como parte da cultura (ZANETIC, 1989) permite que nos aproximemos dos seus produtos, metodologias e de seus construtores, entendendo esses como cidadãos imersos em seus tempos e lugares, e como tais, não gênios isolados e incompreendidos. Esta compreensão da Ciência faz-se necessária para que a mesma não sirva para que se exerça um poder exagerado, em seu nome, pelo simples fato de que o detentor do conhecimento científico é o detentor de um conhecimento superior, neutro e, portanto, inquestionável.

Discutir relações de Ciência e Arte não significa buscar entender relações de influência. Não procuramos construir argumentos que buscaram saber como a Física construída durante o Renascimento foi influenciada pelas novas noções espaciais construídas pelos artistas, ou como os novos conhecimentos construídos pelos cientistas do final do século XIX, sobre a luz, influenciaram os fauves a produzirem pinturas atribuindo à cor um novo significado. Importa-nos construir um painel desses momentos históricos que nos possibilitem compreender a Ciência como um conhecimento que nos ajuda a entender o mundo social, político e cultural e não apenas aspectos do mundo natural.

\section{Referências}

BENOIT, Paul, MICHEAU, Françoise. O Intermediário Árabe. In: SERRES, Michel. Elementos de uma História das Ciências. Lisboa: Terramar, 1998. v. 1. p. 183-212. 
BRAGA, Marco; GUERRA, Andréia; REIS, José Cláudio. Breve História da Ciência Moderna - Volume 1: Convergência de Saberes (Idade Média). Rio de Janeiro: Jorge Zahar Editor, 2004a. ;____ ; ; . Breve História da Ciência Moderna Volume 2: Das Máquinas do Mundo ao Universo-Máquina. Rio de Janeiro: Jorge Zahar Editor, 2004b.

EDGERTON, Samuel Y. The Heritage of Giotto's Geometry - art and science on the eve of the Scientific Revolution. Ithaca; Londres: Cornell University Press, 1991.

GEERTZ, Clifford. A Interpretação das Culturas. Rio de Janeiro: Zahar Editores, 1978.

HENDERSON, Linda D. Einstein and 20th-Century Art: a romance of many dimensions. In: GALISON, Peter; HOLTON, Gerald James; SCHWEBER, Silvan S. Einstein for the 21th century: his legacy in Science, art and modern culture. New Jersey: Princeton University Press, 2008.

MILLER, Arthur. Insights of Genius: imagery and creativity in sciense and art. New York: Copernicus, 1996.

OSTROWER, Fayga. A sensibilidade do intelecto: visões paralelas do espaço e tempo na arte e na ciência. Rio de Janeiro: Campus, 1998.

REIS, José Cláudio; GUERRA, Andréia; BRAGA, Marco. Ciência e Arte: relações improváveis? História, Ciências, Saúde Manguinhos, v. 13 (suplemento), p. 71-87, out. 2006.

ROSSI, Paolo. A Ciência e a Filosofia dos Modernos. São Paulo: Editora UNESP, 1992. 
SCHAPIRO, Meyer. Impressionismo: reflexões e percepções. São Paulo: Cosac \& Naify, 2002.

SHLAIN, Leonard. Art \& Physics: parallel visions in space, time \& light. New York: Morrow, 1991.

SNOW, Charles Percy. As Duas Culturas e uma segunda leitura: uma versão ampliada das Duas Culturas e a Revolução Científica. São Paulo: EDUSP, 1995.

ZANETIC, João. Física também é Cultura. 1989. 252 f. Tese (Doutorado em Educação) - Faculdade de Educação, Universidade de São Paulo, São Paulo, 1989. 


\title{
CIÊNCIA E SOCIEDADE:
}

RETRATOS DA HISTÓRIA DA TERMODINÂMICA NA ARTE

\author{
Danielle Beatriz de Sousa Borges \\ Thaís Cyrino de Mello Forato
}

\section{Ciência e Arte: uma contribuição para o ensino das ciências}

Promover o diálogo entre a Física e a Arte não é uma tarefa trivial, pois ambas se apresentam como culturas totalmente distantes ao primeiro olhar. A Física é compreendida como “[...] o campo da razão, do rigor descritivo da natureza e da precisão. Já a Arte está associada à intuição, à criatividade e à liberdade de criação" (REIS; GUERRA; BRAGA, 2005, p. 29). Conforme desenvolvemos nossas concepções acerca do fazer científico, notamos que tais culturas não são tão antagônicas como pareciam no início (SNOW, 1961). Afinal, ambas são criações da mente humana desenvolvidas em determinados contextos culturais, incorporando aspectos do ideário do local onde estão inscritas.

Quando estudamos a história das ciências, vemos exemplos dos processos de desenvolvimento do conhecimento científico, por exemplo, inter-relacionando Ciência, tecnologia e 
sociedade. Além disso, o estudo histórico mostra a influência de diferentes elementos na Ciência, como valores pessoais, diferentes concepções sobre a constituição da matéria, ou ainda interesses políticos e econômicos, em função do contexto em que as concepções científicas se desenvolvem (MARTINS, 2006). Nesse sentido, as criações das ciências expressam sua historicidade, mostrando-se parte da cultura, influenciando e sendo influenciadas por outros campos do saber.

Essa perspectiva permite-nos entender que os processos de construção dos produtos da Ciência podem estar representados nas criações artísticas de sua época (ZANETIC, 1989, 2006). Diferentes áreas do saber representando um mesmo aspecto desse imaginário, a seu próprio modo. Para Ferreira (2012), a Arte é um processo criativo, também em intenso diálogo com os saberes de sua época.

E assim como a ciência, a arte não é apenas o produto final do quadro, da peça, do roteiro de cinema ou da letra da música. É antes de tudo um processo, idas e vindas de imagens, desejos e expectativas, revisões de conhecimentos anteriores e projeções para o futuro, diferentes linguagens que se cruzam e entrecruzam, enfim, um mistério a penetrar. (FERREIRA, 2012, p. 8)

Ao mesmo tempo em que a Arte também possui suas particularidades, seus movimentos artísticos apresentam diferentes características do pensamento científico de acordo com a época em que surgiram. "A obra artística funciona como o nexo entre a ciência do aluno, a ciência do professor e a ciência do cientista. Nesse sentido, a arte é instrumento de aprendizado" (FERREIRA, 2012, p. 3). A partir daí, entendemos que o professor pode revestir de intencionalidades um produto artístico, 
constituindo-o como um recurso para ensinar Ciência e sobre a Ciência.

Mediante essa perspectiva, o diálogo produzido entre a História da Ciência e a História da Arte pode configurar-se como uma forma de favorecer a reflexão dos alunos sobre o desenvolvimento das ideias científicas (ZANETIC, 2006). As diferentes manifestações artísticas podem oferecer subsídios ao professor para promover discussões sobre os conceitos científicos, bem como sobre sua conexão com seu contexto cultural (REIS; GUERRA; BRAGA, 2009). Por meio de exemplos históricos, os estudantes podem refletir explicitamente sobre aspectos da natureza das ciências (MARTINS, 2006), desenvolvendo uma visão melhor informada sobre as dimensões conceituais, observacionais e socioculturais da Ciência (ALLCHIN, 2013). Utilizando artefatos culturais ${ }^{1}$, aqui sinalizados por intermédio de duas pinturas, buscamos oferecer dois exemplos da Arte incorporando o ideário da Ciência de suas respectivas épocas.

Apresentamos uma interpretação histórica que estabelece uma conexão entre os contextos sociais de duas obras de Arte e um recorte da história da termodinâmica. Utilizando uma delas, um quadro de George Garrard (1760-1826), discutimos uma conexão que busca nos aproximar do contexto científico estabelecido anteriormente ao da Primeira Revolução Industrial, no qual se destacam os conhecimentos relacionados ao estudo da mecânica. Recorrendo a outra obra de arte, um quadro de William Turner (1775-1851), abordamos uma perspectiva de interpretação do seu contexto cultural, quando as máquinas simples dão lugar às máquinas movidas pelo fogo.

${ }^{1}$ Michel de Certeau (1998) considera como artefatos culturais todos os produtos disponibilizados à sociedade. 
O período que separa os dois mundos, representados por essas obras, costuma ser considerado como o início da Primeira Revolução Industrial e constitui um marco na história da termodinâmica, quando as máquinas térmicas vão sendo aperfeiçoadas e passam a ser utilizadas mais intensamente nos transportes e na indústria. Hobsbawm (2010) destaca a dificuldade em se estabelecer um período preciso para a Primeira Revolução Industrial. Porém, boa parte dos historiadores considera que ela teve início na década de 1780, quando ocorreu um grande desenvolvimento industrial se comparado aos anos anteriores, e culminou na construção das ferrovias e da indústria pesada na Grã-Bretanha, na década de 1840.

Nesse contexto, a interpretação das obras de arte presentes nesse trabalho foi baseada na série intitulada "Lendas da Ciência", uma produção francesa escrita pelo filósofo francês Michel Serres (1930- ) e dirigida pelo cineasta francês Robert Pansard-Besson (1950-2011). Essa série é constituída por 12 episódios $^{2}$ que exploram a elaboração do conhecimento científico e o seu poder transformador ao longo da história da Ciência. No episódio "Queimar" ${ }^{3}$, o filósofo francês contrapõe dois mundos ilustrados nos quadros dos pintores ingleses George Garrard (1760-1826) (Figura 1 - p. 146) e William Turner (1775-1851) (Figura 2 - p. 149).

O episódio "Queimar" descreve o primeiro mundo, representado por Garrard em 1784, como frio e limpo, sendo movido pelas forças das águas e dos ventos ou dos músculos dos homens, mulheres e animais. Nesse cenário, destacam-se as máquinas simples, como as alavancas, os guindastes, as

2 Os episódios traduzidos estão disponíveis via You Tube, no canal da TV Escola 1: <https://www.youtube.com/user/TVEscola1>.

3 Título original: Brûler - La Légende des Sciences (1997). 
balanças, as roldanas. Do mesmo modo, o filósofo se transpõe ao mundo do fogo por intermédio do quadro de Turner, pintado em 1839, ilustrando o segundo âmbito, quente e poluído. Nessa perspectiva, ao destacar as ideias que posteriormente iriam contribuir para o estabelecimento de uma nova área na Física, a termodinâmica, o episódio busca mostrar como as transformações promovidas pelas ciências podem influenciar acontecimentos que marcam a história da humanidade.

Obras de arte são consideradas também como documentos históricos, que nos permitem conhecer aspectos do contexto em que foram criadas. A comparação entre essas duas pinturas traz valiosas pistas sobre as transformações sociais operadas pelas máquinas de fogo nesse intervalo de cinco décadas.

As discussões propostas por Michel Serres, por meio da análise das pinturas trazidas ao contexto anterior (séc. XVIII) e posterior à Primeira Revolução Industrial (séc. XIX), podem ser utilizadas didaticamente para introduzir o impacto do desenvolvimento da máquina a vapor, tanto no meio social quanto no científico. É possível refletir sobre as concepções de ciências que permeiam os dois cenários representadas por ambos os pintores.

A reprodução de $O$ Combatente Téméraire (1839), feita no início do século XIX (Figura 2), é a representação de um fato real: mostra o navio de guerra Temeraire ${ }^{4}$ sendo rebocado pelo Tâmisa para um estaleiro de desmontagem. Esse navio é considerado um dos símbolos da nação inglesa, por sua importância na Batalha de Trafalgar durante a guerra franco-espanhola em

\footnotetext{
${ }^{4}$ Há diferentes grafias para o nome do navio no título do quadro quando traduzido do inglês para textos em português. Adotamos a mais frequente no nome da obra, "Téméraire", mas mantivemos a grafia adotada pelos ingleses, Temeraire, quando nos referimos ao navio retratado na obra. Nas citações, mantivemos a opção de cada autor.
} 
1805. A tela ilustra, de forma significativa, a chegada de novos tempos. Em seu quadro, Turner pincela as fumaças produzidas pela máquina a vapor e cria intrigantes atmosferas no seu espaço pictórico (SILVA, 2009).

A representação da máquina a vapor em pinturas nos atenta para o papel que ela estava desempenhando naquele período. O pintor, por meio da obra, consegue expressar o contexto no qual se desenvolve a máquina térmica. $\mathrm{O}$ mundo de Garrard (mecânica) não incorpora a importância do calor na produção de força motriz.

\section{Um mundo dentro dos limites da mecânica}

Em diferentes momentos da história da humanidade, podemos notar a relação entre o desenvolvimento científico e as demandas que envolvem aspectos sociais, econômicos, políticos e até mesmo industriais. Boris Hessen ${ }^{5}$, em seu texto As raízes socioeconômicas dos Principia de Newton, aborda a evolução da mineração no início do século XVI incitada pelo expressivo desenvolvimento da indústria da guerra, e estimulada pela invenção de armas de fogo e pela introdução da artilharia pesada. Assim, a vasta exploração de minas de ferro e cobre foi necessária durante esse período, requerendo o desenvolvimento de novos artefatos e técnicas (HESSEN, 1993). Além disso, para elevar o minério e água,

[...] eram construídos bombas e equipamentos de elevação (sarilhos e molinetes horizontais) empregando

5 Texto apresentado ao II Congresso Internacional de História da Ciência e da Tecnologia - Londres 1931. Tradução de Sylvia Ficher e Ruy Gama. A referência completa está disponível ao final deste capítulo. 
a energia de animais, do vento e de quedas d'água. [...]. Para remover a água, foi preciso desenvolver um sistema completo de bombeamento, uma das tarefas técnicas mais importantes, devido ao aumento de profundidade das minas. (HESSEN, 1993, p. 38)

A maquinaria utilizada na elevação e remoção de minério e água envolvia "[...] questões de cálculo de guinchos e pesos, isto é, de combinação de máquinas mecânicas simples" (HESSEN, 1993, p. 39). Os conhecimentos físicos empregados no desenvolvimento de tais artefatos se encontravam dentro dos limites da mecânica. Ele aponta que esse processo proporcionou um grande progresso técnico, que requisitou o envolvimento de artesãos e ferreiros que possuíam conhecimento da Ciência e que fossem capazes de solucionar os problemas técnicos que acometiam a indústria de mineração. Essa conquista trouxe importantes impactos na vida humana da época. O progresso técnico obtido proporcionou o surgimento da "[...] indústria em larga escala, a aplicação das forças da natureza para fins industriais, a mecanização e uma divisão de trabalho mais detalhada" (HESSEN, 1993, p. 33).

O predomínio da mecânica no ambiente descrito por Hessen estabelece um paralelo com as Artes que expressam por meio das tintas, um mundo dominado pelas máquinas simples. O pintor e escultor inglês George Garrard (1760-1826), em seu quadro intitulado $O$ galpão de Samuel Whitbread (1784) (Figura 1$)^{6}$, recapitula, numa insígnia do trabalho, o conjunto de toda a maquinaria criada pelo homem até então. Nesse conjunto, encontram-se a alavanca, o guindaste, a balança, as roldanas e toda a aparelhagem que transmite força e movimento

${ }^{6}$ Um recorte, em cores, desta figura está na contracapa do livro. 
(SERRES; BROWN; PAULSON, 1997). Todos esses elementos representados por Garrard são exemplos do mundo concebido como essencialmente bem organizado e eterno, anteriormente ao emprego da máquina a vapor nas indústrias e nos transportes (LECHTE, 2012).

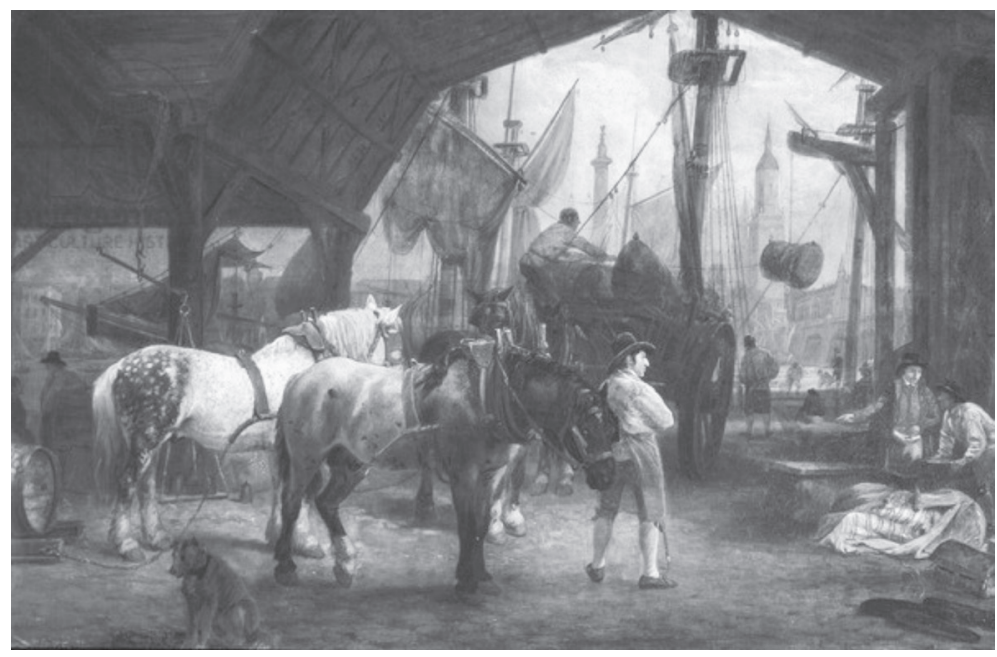

Figura 1 - G. Garrard, Mr. Whitebread's Warf (O galpão do Samuel Whitbread, 1784) ${ }^{7}$

Fonte: Bridgeman Images (2016).

Ao pintá-lo, Garrard não expressa somente seu olhar sobre o mundo do trabalho, mas também - embora, talvez, involuntariamente - descreve as ciências cujas teorias surgem a partir dessas ferramentas com intuito de melhorá-las (SERRES; BROWN; PAULSON, 1997, p. 8).

Porém, o mundo de Garrard se mostra insuficiente diante da demanda energética imposta pelo grande crescimento

7 Pintura a óleo $(60 \times 39,2 \mathrm{~cm})$. 
industrial ocorrido na Inglaterra (HOBSBAWM, 2010). As máquinas deixam de ser artefatos que possuem como função a elevação e bombeamento dos minerais e água presentes no fundo das minas, e passam a ser compreendidas, também, como um elemento capaz de impulsionar os meios de transporte terrestre e marítimos (MENDONZA, 1988) ${ }^{8}$. Essa demanda motiva o aperfeiçoamento das máquinas de fogo ou máquinas de vapor, que encontram um terreno fértil para prosperar.

A presença da máquina a vapor nas pinturas de William Turner reflete sua importância naquele período. Não apenas como meio de transporte mais eficiente, mas, também, por sua contribuição no desenvolvimento industrial inglês. A curiosidade e necessidade em prover melhoramentos a esse artefato, no final do século XVIII e início do século XIX, impulsionou o interesse de engenheiros, artesãos e filósofos naturais na busca por compreender seu funcionamento, inclusive, como mais uma forma de impactar o desenvolvimento social.

\section{As máquinas de fogo e a transformação do mundo}

A máquina a vapor é tida como um dos elementos contribuintes para o advento da Primeira Revolução Industrial, a qual se iniciou por volta dos anos 1780 na Inglaterra (HOBSBAWM, 2010). Segundo Sadi Carnot (1824), ela foi impulsionada pela exploração de grandes jazidas de carvão e ferro

\footnotetext{
8 Nessa edição, Eric Mendonza acrescenta uma introdução à tradução da obra de Sadi Carnot, em que aborda diferentes assuntos relacionados à máquina a vapor na França e Inglaterra. O autor inclui, também, um artigo de Clapeyron e Clausius (MENDONZA, 1988).
} 
disponíveis na região - matérias-primas indispensáveis à confecção das máquinas e geração de energia. Além desses elementos citados por Sadi, outras condições favoreceram esse movimento na Grã-Bretanha, como é exposto por Castignani (1999, p. 7).

A Monarquia já havia sofrido duros revezes, abrindo a possibilidade para um sistema em que o desenvolvimento econômico e os lucros privados tornavam-se o objetivo supremo da política governamental. Uma solução, de efeito prático, havia sido encontrada para o problema agrário, concentrando os negócios numa espécie de monopólio pertencente a uma elite rural de mentalidade já eminentemente comercial.

Não foram o desenvolvimento do motor e a invenção da máquina a vapor que criaram a revolução industrial iniciada no século XVIII. Pelo contrário, a máquina a vapor ganhou grande importância devido à divisão do trabalho desenvolvida na manufatura. A demanda pelo aumento de produtividade tornou possível e necessário inventar um instrumento de execução. A máquina a vapor, que havia nascido na indústria da mineração, encontrou um campo já preparado para sua aplicação como motor (HESSEN, 1993, p. 72). A partir daí, ela também contribuiu para a revolução que estava em curso.

Apesar de a máquina a vapor não ser o único elemento responsável pelo desenvolvimento da revolução industrial, ela despertou interesses dos engenheiros, artesãos, filósofos naturais e cientistas da época. Podem-se encontrar representações desse importante artefato nas Artes, como em algumas pinturas de William Turner (1775-1851), tido como um dos primeiros a representar imagens pictóricas de máquinas a vapor 9 .

\footnotetext{
9 Para mais informações sobre outras obras de arte relacionadas ao tema, há algumas indicações disponíveis no seguinte site: <http://www.historiadaarte. com.br/linha/romantismo.html>.
} 
Apresenta-se aqui uma de suas obras, conhecida como $O$ Combatente Téméraire (1839) (Figura 2$)^{10}$, exposto na primeira metade do século XIX.

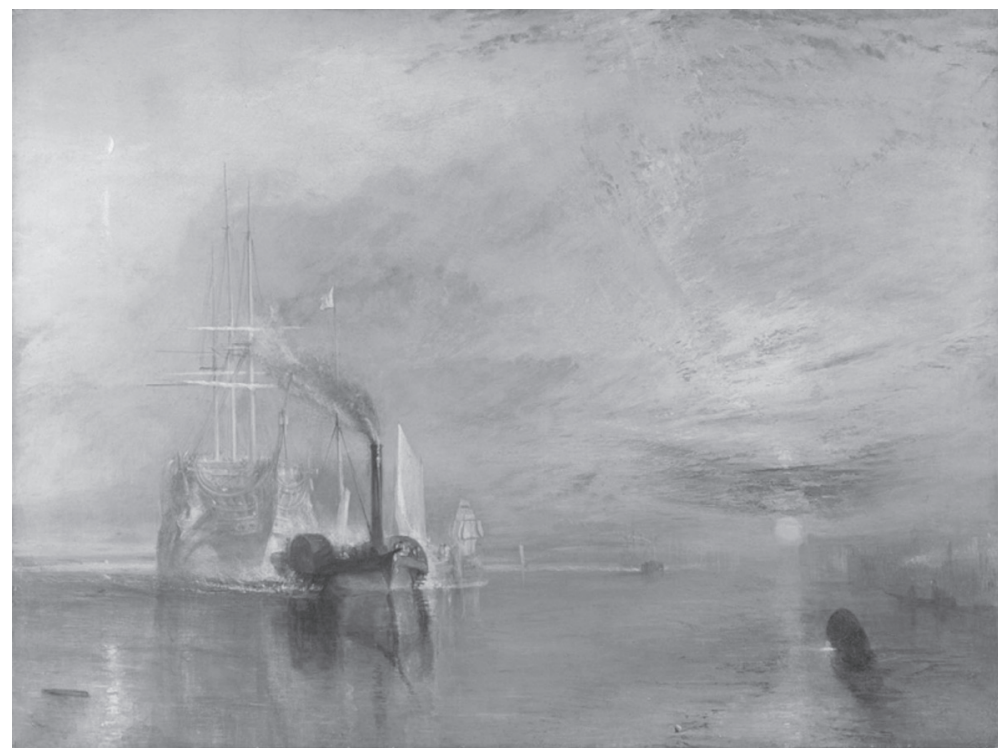

Figura 2 - W. Turner, The Fighting Temeraire tugged to her last berth to be broken up (O Combatente Téméraire, 1838).

Fonte: National Gallery $(2016)^{11}$.

A reprodução de um navio real em $O$ Combatente Téméraire, feita no início do século XIX (Figura 2), ilustra de forma significativa a chegada de novos tempos. Em seu quadro, Turner pincela as fumaças produzidas pela máquina a vapor criando intrigantes atmosferas no seu espaço pictórico (SILVA, 2013). Conforme já citado, a tela é a representação de um fato

10 Esta figura está colorida na capa do livro.

11 Pintura a óleo $(90,7 \times 121,6 \mathrm{~cm})$. 
real: o navio de guerra Temeraire sendo rebocado pelo Tâmisa para um estaleiro de desmontagem.

Todo em branco e amarelo, o Téméraire assume uma fantasmagórica majestade; em contrapartida, os tons escuros do rebocador, expelindo fogo e fuligem, o fazem maligno, quase demoníaco. Nessa escolha de cores também se configura o declínio dos velhos navios a vela, diante da nova era do vapor. (OS GRANDES ARTISTAS, 1991, p. 64)

Mas, a tela de Turner, com um navio a vapor no primeiro plano e o Temeraire ao fundo a ser rebocado, vai além do registro de um fato. Representa o fim de uma era (navegação à vela) e o início de outra (Revolução Industrial).

Turner talvez tenha tentado representar a nostalgia do uso das energias naturais e o início da máquina alimentada a carvão (com a consequente poluição do ambiente), ao pintar o velho e ultrapassado Temeraire como um pálido moribundo, e o novo barco a vapor, de tonalidade escura, triunfante, soltando fogo, com as suas rodas de pás freneticamente agitando a água. Ao refletirmos sobre a navegação à vela e o início da Revolução Industrial evocada pelo quadro de Turner, somos transportados para uma época em que o pensamento da Física não mais se ajustava ao padrão até então existente. (SILVA, 2013, p. 57)

O desenvolvimento da máquina a vapor é mencionado como uma construção inglesa - conforme mencionou Sadi Carnot (1824) - motivado pelo desenvolvimento industrial britânico. Porém, a compreensão dos processos envolvidos no funcionamento desse artefato, considerando a teorização e a sistematização de conhecimentos científicos, desenvolveu-se majoritariamente na França. O interesse da comunidade 
acadêmica em oferecer explicação pautada em ideias científicas foi motivado pelo investimento na educação francesa. Além da importância da estrutura educacional, deve-se considerar a influência de ideias iluministas que elegiam a ciência como sinônimo de progresso, uma entidade capaz de influenciar e impactar, como exemplo, o desenvolvimento social e econômico por meio das práticas científicas (ABRANTES, 1998).

A transição entre o mundo representado por Garrard (Figura 1) e o apresentado por Turner (Figura 2) é marcada pela Primeira Revolução Industrial. Esse importante acontecimento, considerado como tendo seu início na década de 1780 (HOBSBAWM, 2010), impulsionou o desenvolvimento do setor fabril, proveu melhoramentos nos meios de transporte e comunicação e também proporcionou um grande desenvolvimento tecnológico. Esse último aspecto elencado contribuiu para o desenvolvimento científico, que pode ser interpretado por meio das duas obras de arte expostas nesse texto.

Os conhecimentos que favorecem a compreensão do mundo representado por Garrard - a mecânica -, por meio de suas leis e teoremas, respondem satisfatoriamente sobre o funcionamento das máquinas simples. Porém, tais conhecimentos são insuficientes quando conhecemos o mundo representado por Turner, o mundo do fogo, tido como um importante elemento para o funcionamento de máquinas que não são mais acionadas por meio da tração animal ou pela força humana.

\section{Duas pinturas, dois mundos e as máquinas térmicas no ensino}

Como pudemos ver ao longo desse artigo, o desenvolvimento das máquinas vem ocupando um importante papel no 
progresso da sociedade. Hessen nos apresentou o impacto das máquinas simples, representadas por Garrard, como elemento contribuinte nos estudos da mecânica. Tais estudos se mostraram frutíferos tanto do ponto de vista prático, aperfeiçoando os processos executados pelas máquinas, quanto na ciência, exigindo aprofundamento em questões de cálculo de forças de tração e pesos que comporiam as máquinas mecânicas simples.

Apesar da importância dos estudos da mecânica na compreensão do funcionamento das máquinas, como citamos no início do texto, necessitava-se de um conhecimento que contribuísse no entendimento das máquinas a vapor, privilegiando seu rendimento. Os conceitos e as teorias que eram conhecidos até aquele período não eram suficientes para o que se necessitava compreender. Sadi Carnot escreveu que, enquanto os motores impulsionados por água, ar, ou a força animal poderiam ser totalmente analisados pela teoria mecânica, uma teoria semelhante para o estudo dos motores de calor permanecia ausente (CARDWELL, 1965, p. 189).

A transformação do calor da caldeira de uma máquina em força de um volante, se bem que utilizada amplamente, permaneceu durante muito tempo como uma questão estranha para a ciência exata. Cada máquina tinha seu próprio índice de conversão do carvão em trabalho, e este índice parecia descer à medida que se melhoravam as máquinas sem que parecessem advertir algum limite para o rendimento. Sem dúvida, este limite tinha que existir, pois de outro modo seria possível o movimento contínuo. Estas considerações conduziram Sadi Carnot, [...], e suas Réflexions [...]. (CASTIGNANI, 1999, p. 10)

A pintura de Turner foi divulgada em 1839. Nesse período, Sadi Carnot já havia publicado sua obra Réflexions Sur la Puissance Motrice du Feu et Sur les Machines Propres a 
Développer Cette Puissance, (Reflexões sobre a potência motriz do fogo e sobre as máquinas próprias a desenvolver essa potência), em 1824. Em princípio, este livro não chamou muito a atenção da comunidade científica. Entretanto, na década seguinte, a publicação de Émilie Clapeyron (1834) ${ }^{12}$, que ofereceu uma matematização e os diagramas para os ciclos propostos por Carnot (como os conhecemos atualmente), contribuiu para as discussões sobre a compreensão do poder do calor na produção de potência motriz ${ }^{13}$. Essa ideia foi central para os cientistas franceses da época, visto que estavam preocupados em prover melhorias nas máquinas a vapor já existentes, com intuito de impactar o desenvolvimento econômico francês.

Além de sua preocupação em entender o processo de produção da potência motriz ocorrido em máquinas térmicas, Carnot acreditava que tal artefato seria capaz de transformar o modo de produção de trabalho ${ }^{14}$, substituindo a transformação de energia por meio da tração animal, das quedas d'água e pelas correntes de ar, pelo poder do fogo.

No início de seu livro, Carnot faz a apologia da utilização das máquinas a vapor. Em seu trabalho, ele busca propor princípios gerais com intuito de atender diferentes tipos de máquinas térmicas, independentemente do combustível utilizado em seu funcionamento. Em busca da compreensão desses princípios, Sadi Carnot propôs inicialmente dois questionamentos que conduziram seu estudo, que são: i) seria a potência motriz do calor ilimitada ou haveria um limite para ela?; ii) existiriam agentes preferíveis ao vapor d'água para a produção da força motriz do calor?

12 Artigo publicado no Journal de l'Ecole Royale Polytechnique, intitulado Mémoire sur la puissance motrice de la chaleur (CLAPEYRON, 1834).

13 Sadi Carnot e seus contemporâneos utilizam o termo potência motriz para representar o que compreendemos atualmente por rendimento, que seria a relação entre a energia recebida por um sistema e o trabalho realizado por ele. ${ }^{14} \mathrm{Na}$ concepção atual de transformação de energia térmica em outras modalidades. 
Como forma de facilitar a compreensão dos princípios da produção de movimento pelo calor, Sadi Carnot determina que esses elementos devem ser considerados independentemente de qualquer mecanismo ou agente especial. Ele ainda destaca que é necessário estabelecer fundamentos aplicáveis não apenas aos motores a vapor de água, mas também a outros tipos de motores que poderiam ser desenvolvidos. Por essas razões, Carnot idealiza uma máquina que poderá operar independentemente da substância utilizada e seu método de execução.

Durante seus estudos, Sadi Carnot descreveu um ciclo ideal para um sistema constituído por um gás e composto por um cilindro com um êmbolo livre (Figura 3), sem atrito.

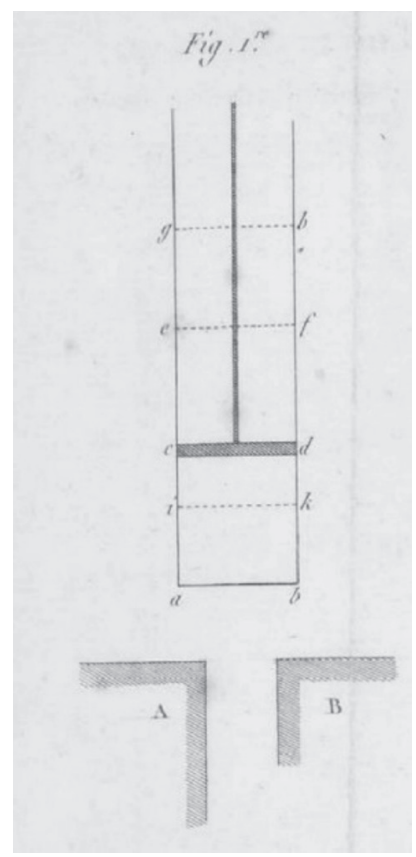

Figura 3 - Desenho feito por Sadi Carnot (1824) Fonte: Carnot (1824, p. 119). 
Carnot descreve que os corpos A e B representam reservatórios térmicos que apresentam temperaturas constantes, $T_{A}$ e $T_{B}$, respectivamente, visto que $T_{A}$ é maior do que $T_{B}$.

Nesse desenho, são indicadas quatro posições para o êmbolo. Inicialmente, o êmbolo é posicionado na posição c-d, e o sistema é colocado em contato com o reservatório $A^{15}$. Durante esse processo, Carnot (1824) enfatiza que o máximo aproveitamento do calórico ${ }^{16}$ para a produção do movimento ocorreria quando todas as mudanças de temperatura, no fluido, acontecessem devido a mudanças de volume. A partir de seus estudos, o autor estabelece que os fluídos elásticos (gás ou vapor) possuem melhor desempenho na produção de potência motriz do fogo. Ele complementa:

Quando um gás mantido a uma temperatura constante passa de um volume $\left(V_{1}\right)$ e pressão $\left(p_{1}\right)$ para outro volume $\left(V_{2}\right)$ e outra pressão $\left(p_{2}\right)$ a quantidade de calórico absorvido ou abandonado é sempre a mesma, independentemente do tipo de gás. (CARNOT, 1824, p. 42)

O estudo do ciclo proposto por Carnot, em 1824, pode contribuir no aprendizado dos conceitos físicos envolvidos nas propriedades dos gases, considerando suas variáveis (temperatura, volume, pressão). Como também, processos reversíveis e

15 Em Borges (2016), há uma descrição detalhada do Ciclo de Carnot, disponível nas páginas 48-49.

${ }^{16}$ Ao final do século XVIII e início do XIX, havia debates sobre a natureza do calor entre os cientistas da época. Um grupo considerava a existência de um fluído imponderável, o que era responsável pelas mudanças de temperatura observadas nos corpos. Outro grupo possuía uma concepção de calor como o movimento insensível das moléculas. Para um estudo mais completo sobre as teorias relacionadas à natureza do calor, indicamos a leitura do artigo Concepções sobre a natureza do calor em diferentes contextos históricos (SILVA; FORATO; GOMES, 2013). 
irreversíveis e suas implicações. Além dos conteúdos científicos aqui elencados, buscamos abordar um conteúdo da História da Ciência que nos permite compreender como uma demanda da sociedade, permeada por interesses sociais, econômicos e políticos pode contribuir na compreensão da Ciência como parte da cultura humana.

\section{Algumas considerações sobre as interpretações das pinturas e da história}

Os dois pintores buscam representar, por meio das pinturas discutidas, suas visões de mundo de dois períodos distintos. Na obra de Garrard, vemos a representação de um mundo constituído e compreendido pela Mecânica. Ao passo que Turner buscou enunciar a chegada de novos tempos, um período dominado pelo fogo, que impulsionou estudos relacionados à termodinâmica. Ao compararmos as duas obras e seus contextos, ficaram explícitos alguns aspectos que podem exemplificar as dimensões conceituais, observacionais e socioculturais da Ciência (ALLCHIN, 2013). Além disso, essa ponte entre a Ciên-

cia e a Arte nos mostra como vários desses aspectos estão tão intimamente relacionados (SNOW, 1961) que é quase impossível separá-los.

Aproximar os elementos constituintes dessas obras, como, por exemplo, as representações das máquinas simples na pintura de Garrard e a máquina a vapor representada em tela por William Turner, em conjunto com as demandas sociais impostas nos períodos retratados pelos artistas, pode favorecer discussões que contribuam no entendimento da ciência como parte da cultura humana. "A ciência é uma das leituras possí- 
veis do mundo e da natureza. Cada época e cada cultura são permeadas por diversas inquietações e questões que produzem respostas de diferentes tipos" (REIS; GUERRA; BRAGA, 2009, p. 1763). Esses valores podem ser caracterizados pelas influências sociais, políticas, econômicas, tecnológicas, dentre outras, que podem se refletir nos estudos científicos.

Não se pretende eleger um mundo melhor que o outro, quando comparadas as representações de Garrard e Turner. Porém, essa análise pode contribuir para compreender mudanças ocorridas em determinados períodos e sua relação com o desenvolvimento científico. Michel Serres elege a Primeira Revolução Industrial como elemento construtor de um elo nas transformações ocorridas entre os mundos representados pelos pintores.

Esse exemplo de interação entre a Ciência desenvolvida em um contexto histórico e sua representação nas Artes do período pode subsidiar aulas de Física que intentam discutir aspectos que motivaram o estudo das máquinas térmicas. Tal abordagem tem como intuito favorecer discussões que valorizem os conceitos científicos, bem como as dimensões socioculturais que compõe a construção da ciência.

\section{Referências}

ABRANTES, Paulo César Coelho. Imagens de natureza, imagens de ciência. São Paulo: Papirus, 1998.

ALLCHIN, Douglas. Teaching the Nature of Science: Perspectives \& Resources. Saint Paul, MN: SHiPS Educational Press, 2013.

BORGES, Danielle Beatriz de Sousa. A Construção de uma Abordagem Histórica para o Ensino de Termodinâmica: Sadi 
Carnot e o estudo da máquina térmica. 2016. 111 f. Dissertação (Mestrado em Ensino e História das Ciências e da Matemática) Universidade Federal do ABC, Santo André, 2016.

; FORATO, Thaís Cyrino de Mello. Sadi Carnot and the ideal steam machine: thermodynamics and the social, economic and political context in teacher education. In: IHPST THIRTEEN BIENNIAL INTERNATIONAL CONFERENCE, july 22-25 2015, Rio de Janeiro. Anais eletrônicos... Rio de Janeiro: IHPST, 2015. Disponível em: <http://www.abq.org.br/ihpst2015/acceptedpapers.html>. Acesso em: 12 jan. 2016.

BRIDGEMAN IMAGES. Mr Whitbread's Wharf (oil on canvas). 2016. Disponível em: <http://www.bridgemanimages.com/ en-GB/asset/4936/garrard-george-1760-1826/mr-whitbread-swharf-oil-on-canvas>. Acesso em: 8 jul. 2016.

CARDWELL, Donald S. L. Power Technologies and the Advance of Science, 1700-1825. Technology and Culture, v. 6, n. 2, p. 188-207, 1965. Disponível em: <http://www.jstor.org/stable/3101073>. Acesso em: 10 mar. 2015.

CARNOT, Nicolas Léonard Sadi. Réflexions Sur la Puissance Motrice du Feu et Sur les Machines Propres a Développer Cette Puissance. Paris: Chez Bachelier, 1824.

CASTIGNANI, Aristides. Sadi Carnot e o Desenvolvimento Inicial da Termodinâmica Clássica. 1999. 172 f. Dissertação (Mestrado em História da Ciência) - Pontifícia Universidade Católica de São Paulo, São Paulo, 1999.

CERTEAU, Michel de. A invenção do cotidiano: artes do fazer. Petrópolis: Vozes, 1998. 
CLAPEYRON, Émile B. Mémoire sur la puissance motrice de la chaleur. Journal de l'Ecole Royale Polytechnique, cahier 23, p. 153-190, 1834.

FERREIRA, Fernando C. Arte: aliada ou instrumento no ensino de ciências? Revista Arredia, Dourados, v. 1, n. 1, p. 1-12, jul./ dez. 2012.

GUERRA, Andréia; BRAGA, Marco; REIS, José Cláudio. Física e Arte: Uma Proposta para a Compreensão Cultural da Ciência. Enseñanza de las Ciencias, número extra, p. 1763-1766, 2009.

HESSEN, Boris. As raízes sócio-econômicas dos Principia de Newton. In: GAMA, Ruy (Org.). Ciência e Técnica: antologia de textos históricos. São Paulo: T. A. Queiroz, 1993. p. 30-89.

HISTÓRIA DAS ARTES. Disponível em: <http://www. historiadasartes.com/>. Acesso em: 8 jul. 2016.

HOBSBAWM, Eric J. A Revolução Industrial. In: . A eradas revoluções: 1789-1848. São Paulo: Paz e Terra, 2010. p. 57-97.

LECHTE, John. Genealogy and Ontology of the Western Image and its Digital Future. New York: Routledge, 2012.

MARTINS, Roberto de Andrade. Introdução: a história da ciência e seus usos na educação. In: SILVA, Cibelle Celestino (Org.). Estudos de história e filosofia das ciências: subsídios para aplicação no ensino. São Paulo: Editora Livraria da Física, 2006. p. xvii-xxx.

MENDONZA, Eric (Ed.). Reflections on the Motive Power of Fire by Sadi Carnot and other Paper on the Second Law of Thermodynamics by É. Clapeyron and R. Clausius. New York: Dover Publications, 1988. 
NATIONAL GALLERY. The Fighting Temeraire - 1839, Joseph Mallord William Turner. Disponível em: <http://www. nationalgallery.org.uk/paintings/joseph-mallord-william-turnerthe-fighting-temeraire>. Acesso em: 8 jul. 2016.

OS GRANDES ARTISTAS. Romantismo e Impressionismo: Cézanne, Gauguin, Turner. 2. ed. São Paulo: Nova Cultural, 1991.

REIS, José Cláudio; GUERRA, Andréia; BRAGA, Marco. Física e arte: a construção do mundo com tintas, palavras e equações. Ciência e Cultura, São Paulo, v. 57, n. 3, set. 2005.

SERRES, Michel; BROWN, Catherine; PAULSON, William. Science and the Humanities: The Case of Turner. SubStance, v. 26, n. 2. Disponível em: <http://www.jstor.org/stable/3684693>. Acesso em: 5 mar. 2015.

SILVA, Ana Paula Bispo; FORATO, Thaís Cyrino de Mello; GOMES, José Leandro de A. M. Costa. Concepções sobre a natureza do calor em diferentes contextos históricos. Caderno Brasileiro de Ensino de Física, v. 30, p. 492-537, 2013.

SILVA, Djalma N. A Termodinâmica no Ensino Médio: ênfase nos processos irreversíveis. 2009. 132 f. Dissertação (Mestrado em Ensino de Física) - Faculdade de Educação, Instituto de Física, Instituto de Química e Instituto de Biociências, Universidade de São Paulo, São Paulo, 2009.

. Ensino e Aprendizagem da Termodinâmica: Questões Didáticas e Contribuições da História da Ciência. 2013. 250 f. Tese (Doutorado em Ensino de Física) - Faculdade de Educação, Instituto de Física, Instituto de Química e Instituto de Biociências, Universidade de São Paulo, São Paulo, 2013. 
SNOW, Charles P. The Two Cultures and The Scientific Revolution. New York: Cambrigde University Press, 1961.

TV ESCOLA 1. Disponível em: <https://www.youtube.com/user/ TVEscola1>. Acesso em: 8 jul. 2016.

ZANETIC, João. Física também é cultura. 1989. 252 f. Tese (Doutorado em Educação) - Faculdade de Educação, Universidade de São Paulo, São Paulo, 1989.

- Física e Arte: uma ponte entre duas culturas.

Pro-Posições, Campinas, v. 17, n. 1, p. 39-58, 2006. 


\section{A CIÊNCIA COMO VILÃ NO CINEMA:} UM ESTUDO A PARTIR DA LINGUAGEM CINEMATOGRÁFICA

Aennder Ferreira de Sousa Breno Arsioli Moura

\section{Introdução}

Desde as primeiras exibições cinematográficas realizadas publicamente no final da década de 1890 , o cinema encantou, fez pessoas se emocionarem, veiculou visões políticas, científicas, culturais e religiosas, buscando entreter a sociedade e tornar sua vida mais alegre e informada. Com o passar dos anos, novas formas de criação foram inventadas e aprimoradas pelos próprios cineastas da época, com o intuito de surpreender o público cada vez mais. Assim, o cinema conquistou seu espaço na sociedade, garantindo ao público imersões culturais pouco vivenciadas. Ele abriu portas para a imaginação, para a compreensão de outros mundos e culturas, para o questionamento de visões políticas e científicas etc. (SOUSA, 2016).

O caráter vilanesco da Ciência sempre ocupou um lugar de destaque no cinema. Fugindo da proposta cinematográfica 
que abordava viagens para a lua e "marcianos", presentes nos primeiros filmes, como Viagem à Lua (1902), de George Méliès (1861-1938), em 1927, Fritz Lang (1890-1976), um dos pioneiros do cinema expressionista alemão, ${ }^{1}$ aventurou-se em prever o futuro da humanidade do ano de 2026 no filme Metrópolis (1927), com uma cidade tecnológica e futurística. O contexto da obra é o pós-guerra, com a presença de cenários distorcidos, personagens e fotografia sombrias, que tinham o objetivo de ressaltar que o mundo estava fora de perspectiva, devido às tragédias da Primeira Guerra Mundial. Em Metrópolis (1927), já podemos notar a importância do contexto temporal e espacial em que um filme é desenvolvido, uma vez que sua visão de futuro tinha estreita relação com o seu próprio presente.

Metrópolis constrói uma problemática rica no que concerne às divisões de classes sociais, enfatizando as interações existentes entre sociedade, governo opressor e o desenvolvimento tecnológico. Chama a atenção a imagem de cientista construída nessa obra. No filme, C. A. Rotwang (Rudolf Klein-Rogge) é um cientista e inventor que perde seu único e verdadeiro amor para Joh Frederson (Gustav Fröhlich), governante de Metrópolis. Para suprir a falta de Maria (Brigitte Helm), Rotwang desenvolve um robô que substituiria sua esposa, mas, depois desses eventos, sua insanidade começa a reduzi-lo à loucura.

\footnotetext{
1 O termo expressionismo foi proposto pelo crítico e historiador da arte W. Worringer (1911) para qualificar um conjunto de obras pictóricas que eram opostas ao impressionismo. Dentre as diversas definições de expressionismo cinematográfico, as que possuem maior destaque são: tratamento da imagem como "gravura", com forte contraste preto e branco; os cenários bem gráficos, em que predominam as linhas oblíquas; o jogo "enviesado "dos atores e o tema da revolta contra a autoridade. O cinema expressionista sempre mostrou como cultivar as imagens fortes, violentas e expressivas (AUMONT; MARIE, 2003).
} 
O cientista idealizado por Lang é submisso aos dominadores elitistas de Metrópolis, e é influenciado constantemente por questões pessoais e sociais no processo de seu fazer científico. Esse filme introduziu um novo elemento para caracterizar cientistas em obras cinematográficas posteriores: o cientista maluco (PERKOWITZ, 2007, p. 6).

Durante os anos de 1939-45, a humanidade vivenciou a Segunda Guerra Mundial, um dos eventos mais sangrentos dos tempos recentes, que resultou na morte de milhões de pessoas. Após a guerra, a sociedade como um todo se transformou, pois sentimentos como medo e insegurança tornaram-se comuns entre os cidadãos. Nessa perspectiva, a sociedade passou a questionar a ciência e as consequências causadas pelo domínio científico. A partir disso, novas ideias sobre ciência começaram a se propagar nas obras cinematográficas, como o medo do mundo atômico e as invasões marcianas, que, em alguns filmes, era ressaltada pelo uso do vermelho, para que os espectadores relacionassem os invasores aos comunistas.

A partir do ano de 1950, os filmes apresentaram questionamentos sobre as capacidades da ciência e como elas poderiam influenciar os contextos sociais, políticos e bélicos. Sendo assim, filmes que abordavam as temáticas de corrida espacial, poder atômico e rivalidades entre comunistas e capitalistas começaram a dominar as telas do cinema.

Para Perkowitz (2007, p. 7), Viagem à Lua e Metrópolis são filmes da era pré-moderna da ficção científica. Sobchack (1997) afirma que a era moderna do cinema científico inicia-se em 1950, com Destino à Lua (1950), filme que narra a história da primeira viagem bem-sucedida à lua. Nessa obra, os exploradores lidam com possíveis falhas do equipamento de navegação e com a possibilidade de não regressar à Terra. Diversos filmes 
de ficção científica foram produzidos após esse, e suas criações trouxeram abordagens ao cinema hollywoodiano que persistem até os dias atuais, tais como em Gravidade (2013), Apollo 13 (1995), 2001 - Uma Odisseia no Espaço (1968), entre outros.

A ciência evidenciada em Destino à Lua é considerada por Perkowitz (2007, p. 8) como coerente, mediante a abordagem científica apresentada pelo cineasta. A partir de um toque perspicaz do diretor, o filme utilizou artifícios didáticos para conquistar os espectadores e fazer com que esses compreendessem de forma superficial a física que constituía a viagem à lua. Para isso, ele utilizou um cartoon do personagem Pica-Pau discutindo e explicando o lançamento de uma espaçonave.

O dia em que a Terra parou (1951), do cineasta Robert Wise, colocou em questão as guerras e brigas armamentistas, dois problemas que deixaram habitantes de outros planetas inquietos. Preocupados com o progresso científico na Terra e com a instabilidade humana, eles enviaram Klaatu (Michael Rennie) e seu robô Gort para clamarem aos governantes que parassem com as guerras e as buscas por novas descobertas sobre armas nucleares, pois caso não fizessem, eles seriam destruídos. O filme discute na sua narrativa, de forma mais crítica, o posicionamento da sociedade perante as guerras e os problemas causados pelo desenvolvimento das armas, que são direta e indiretamente fomentados pelo avanço científico. O teor da discussão nas obras é reflexo dos questionamentos sobre a ciência no contexto de produção dos filmes, e isso demonstra o quão influente a ciência é, e como ela pode intervir em fatores externos à prática científica.

Ainda nos tempos atuais, podemos encontrar obras que abordam as possíveis consequências maléficas do desenvolvimento científico. Por exemplo, em O Dia Seguinte (1983), vemos 
os efeitos de uma bomba atômica sobre uma cidade estadunidense, bem no meio da intensa Guerra Fria travada entre os Estados Unidos e a URSS na época. Em O Extermidador do Futuro 1 (1984) e 2 (1991), somos apresentados a um mundo destruído pelas máquinas, em que os humanos enviam androides ao passado para evitar a ascensão de robôs com sofisticada inteligência artificial. Em Elysium (2013), filme ambientado em 2159, o mundo está dividido entre dois grupos: os ricos que ocupam a estação espacial Elysium e os pobres que vivem na terra, repleta de doenças e em decadência. Em Eu sou a Lenda (2007), vemos um mundo pós-apocalíptico causado pela criação de uma vacina contra o câncer que espalha efeitos colaterais incontroláveis na população. Mais exemplos não faltam nessa temática.

Neste capítulo, buscamos avançar na discussão sobre como o cinema retrata as consequências maléficas da Ciência para a sociedade, mas a partir de uma perspectiva ainda não muito explorada na literatura especializada e utilizando exemplos de filmes recentes, produzidos nos últimos 20 anos. $O$ estudo se pauta em elementos da linguagem cinematográfica utilizados pelos cineastas. Entendemos como elementos da linguagem cinematográfica o conjunto de artifícios utilizados pelos cineastas para construir a narrativa fílmica. A partir deles, é possível construir questões psicológicas dos personagens, ressaltar objetos e sua importância dentro de um enquadramento, situar os espectadores no período histórico e geográfico, entre outros pontos (SOUSA, 2016).

Os elementos da linguagem cinematográfica são parte inerente de todo filme. Entretanto, o cineasta pode utilizá-los para ressaltar aspectos da narrativa, fornecendo ao espectador subsídios para uma interpretação mais completa da obra, de seus propósitos, de seus significados e de sua essência. Com 
base nisso, buscamos perceber como os cineastas utilizaram enquadramentos, figurinos e design de produção para ressaltar o caráter vilanesco da ciência em três filmes com temática científica: Gattaca (1997), Eu, Robô (2004) e O Preço do Amanhã (2011).

Para estudar as obras, utilizamos a metodologia de análise fundamentada em Vanoye e Goliot-Lété (2013), que visa a explorar a obra cinematográfica a partir de uma análise crítica e reflexiva da obra fílmica. Nessa perspectiva, entendemos a análise como uma desconstrução e reconstrução. A desconstrução significou determinar quais cenas possuíam elementos que poderiam indicar o caráter vilanesco da ciência. A reconstrução foi interpretar como esses elementos foram efetivamente empregados para mostrar a ciência como vilã, confirmando ou não a indicação da etapa anterior.

Em um primeiro momento, a partir da metodologia adotada, selecionamos as cenas dos Fotogramas 1 a $3^{2}$, pois acreditamos que, com o uso de determinados planos e angulações, o cineasta Andrew Niccol conseguiu demonstrar, em Gattaca, que a Ciência pode ser utilizada como objeto repressor e tornar a sociedade inferior e submissa a ela. Em seguida, selecionamos as cenas dos Fotogramas 4 e $5^{3}$ do filme $O$ preço do amanhã, em que se evidencia o uso de figurinos específicos para determinar a divisão de classes retratada no filme. Posteriormente, em $E$, robô buscamos cenas que destacassem a superioridade das máquinas quando comparadas aos humanos. A partir disso, selecionamos as cenas retratadas nos Fotogramas 6 e $7^{4}$, que destacam a presença dos robôs na sociedade do futuro e por qual motivo, em certo momento, eles se tornam ameaçadores.

2 Todos os direitos reservados a (C) Columbia Pictures Industries.

3 Todos os direitos reservados a (C20th Century Fox.

4 Todos os direitos reservados a (C20th Century Fox. 
A discussão aqui apresentada alinha-se com a proposta do livro, uma vez que oferece ao professor recursos para uma nova abordagem do cinema em sala de aula, explorando não apenas questões do roteiro do filme, mas também outros elementos que fazem parte de sua composição e que possuem tanta importância quanto a história contada.

\section{Gattaca}

Gattaca (1997), dirigido por Andrew Niccol (1964-), mostra um "futuro não muito distante", no qual os seres humanos são concebidos geneticamente em laboratórios de manipulação genética. Para a sociedade de Gattaca, as pessoas concebidas de forma natural são "inválidas", pois elas não possuem as qualidades genéticas perfeitas e são inferiores aos concebidos artificialmente. Ao nascer, cada indivíduo é classificado por meios de cálculos probabilísticos de suas qualidades genéticas, o que define suas características psicológicas, físicas, provável causa da morte e possíveis doenças. A organização social no contexto futurista apresentado por Niccol não é determinada por classes sociais, mas pela ciência. Dessa forma, as classes sociais inferiores são representadas por indivíduos concebidos naturalmente. Aqueles concebidos artificialmente ocupam as melhores posições sociais e são bem-sucedidos profissional e financeiramente.

Vincent Freeman ${ }^{5}$ - protagonista do filme - é considerado inválido, pois ele foi concebido naturalmente, sem modificações genéticas. Ao nascer, ele foi definido como "filho de Deus",

\footnotetext{
${ }^{5}$ Interpretado por Mason Gamble (criança), Chad Chirst (adolescente) e Ethan Hawke (adulto).
} 
que nasceu com $60 \%$ de probabilidade de problemas neurológicos, $42 \%$ de probabilidade de depressão, $89 \%$ de probabilidade de distúrbio de concentração e $99 \%$ de probabilidade de desenvolver doenças de coração. Para o contexto do filme, nascer com chances de ter diversos problemas de saúde torna o indivíduo incapacitado de executar tarefas de grande relevância na sociedade, sendo suas funções restritas a trabalhos de serviços gerais.

Desde a infância, Vincent sonhava em ingressar em Gattaca, uma agência espacial que treinava e enviava os melhores astronautas para atividades de exploração espacial. Como essa instituição possuía grande visibilidade pela sociedade, para fazer parte da rotina de treinamentos era necessário que os contratados tivessem perfis genéticos sem falhas. Por causa dos problemas que suas credenciais apresentavam, a primeira visita de Vincent a Gattaca foi como membro de um grupo de limpeza que realizava serviços gerais para a empresa. Ele jamais poderia se tornar astronauta sendo um "inválido".

Alguns anos após o nascimento de Vincent, seus pais resolveram ter outro filho, mas dessa vez eles não quiseram confiar suas qualidades ou dificuldades nas mãos de Deus. Sendo assim, eles procuraram um geneticista para pesquisar a melhor combinação genética existente a partir de seus genes, gerando uma pessoa "válida". Anton Freeman ${ }^{6}$ nasceu com qualidades genéticas dignas de herdar o nome do próprio pai, que anteriormente seria dado a Vincent.

Durante a infância, Vincent sempre fora deixado de lado pelos seus pais e, nas disputas de natação que ele tinha com seu

6 Interpretado por Vincent Nielson (criança), William Lee Scott (adolescente) e Loren Dean (adulto). 
irmão, sempre perdia, por conta da sua deficiência genética e da falta de credibilidade que ele mesmo se dava. Até que, na sua adolescência, Vincent decidiu disputar com seu irmão novamente, da mesma forma que eles faziam enquanto crianças, quando o surpreendente aconteceu: Vincent superou suas limitações genéticas, e venceu o irmão, que não teve força suficiente para acompanhá-lo. Nesse momento, Vincent passou a acreditar em si e, cansado de todo o isolamento ao qual a família o submeteu, resolveu sair de casa e correr atrás de seus sonhos.

Para se juntar à Gattaca, Vincent precisava de conhecimentos de Física, Matemática e treinamento físico. Ele poderia dedicar horas de estudos e treinamentos para melhorar seu desempenho, mas a única chance de entrar em Gattaca como um explorador espacial seria a partir do perfil genético. Sendo assim, Vincent procurou um negociador de identidades falsas, que o apresentou a Jerome Morrow, grande astro de natação que sofreu um acidente fora do país e tornou-se paraplégico. Após um processo doloroso de transformação física, Vincent assumiu a identidade "válida" de Jerome. Como Jerome, Vincent ingressou em Gattaca, mas logo teve seu segredo posto em jogo quando um diretor do programa foi assassinado e uma intensa investigação começou a acontecer no interior da instituição.

No filme Gattaca, o diretor Andrew Niccol utilizou elementos cinematográficos para ressaltar o poder da Ciência e demonstrar como a sociedade tornou-se submissa ao seu discurso. Nesse contexto, os personagens sucumbiram sua humanidade para seguir as regras imposta pela elite social, que em Gattaca é definida pelos padrões genéticos.

Para ressaltar a vulnerabilidade do personagem Vincent, o cineasta utilizou o plano de filmagem com angulação plongée. Esse plano consiste em filmar os personagens de cima para 
baixo, para fazer deles objetos presos a um determinismo insuperável (MARTIN, 2013, p. 44). A partir desse ângulo de filmagem, o diretor buscou ressaltar o sentimento e as aflições do personagem em sua totalidade, tais como seu isolamento do mundo e sua incapacidade de ser tão bom quanto as crianças concebidas artificialmente. O posicionamento do ator no centro do enquadramento, rodeado pelo mar esverdeado, insinua que Vincent está sendo engolido em sua inferioridade. No contexto do filme, o plano utilizado nessa sequência de cenas parece sugerir que a Ciência fomenta um ambiente repressor, limitando as pessoas que não possuem credenciais genéticas bem vistas pela sociedade de Gattaca.

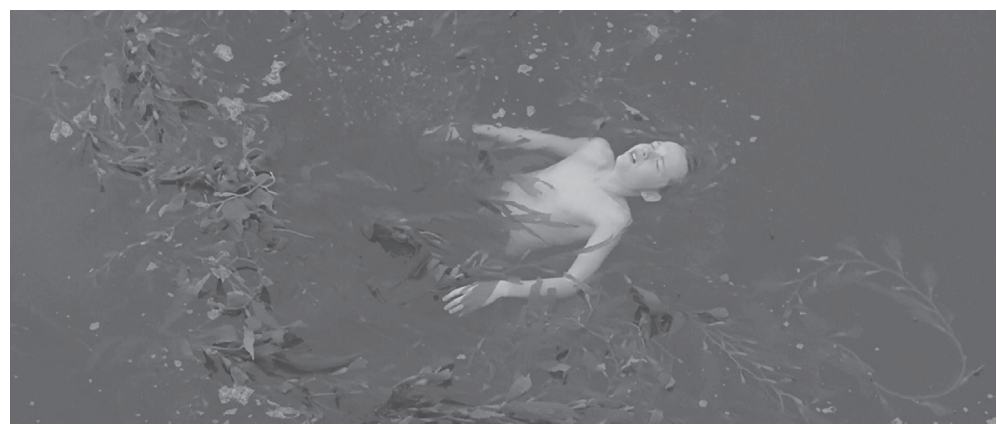

Fotograma 1 - Plano plongée utilizado por Niccol para salientar a vulnerabilidade do personagem [ $12 \mathrm{~min} 36 \mathrm{~s}$ ].

Fonte: Gattaca (1997).

Usualmente, filmes de ficção científica têm suas narrativas preenchidas com visões de senso comum sobre o cientista, geralmente retratado com jaleco e cabelo despenteado, como em De volta para o futuro $(1985,1989,1990)$, Metrópolis (1927) e O Professor Aloprado (1996). Em Gattaca, elementos de cena e figurinos ressaltam o retrocesso causado pela Ciência. 
As roupas utilizadas por Vincent e outros personagens pouco sugerem que eles pertençam a uma estação espacial, estando mais próximos de executivos dos anos 1950. O desenvolvimento da Ciência parece tê-los levado ao passado, não ao futuro.

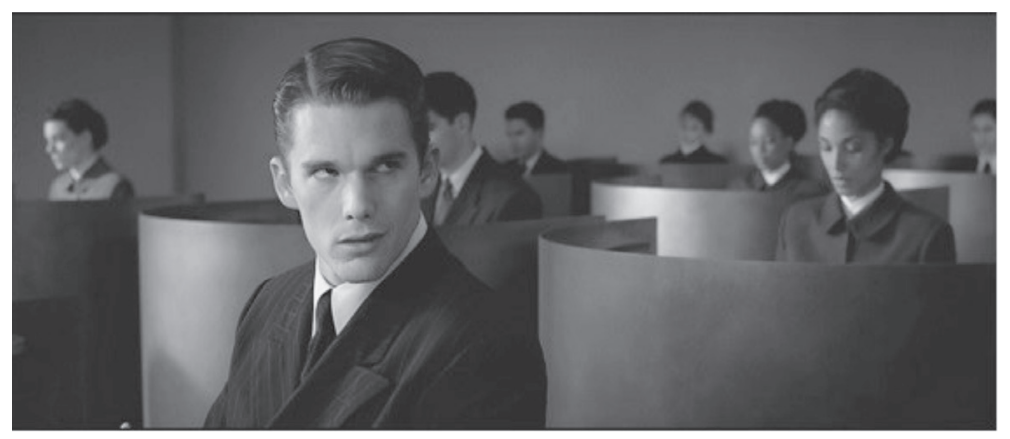

Fotograma 2 - Roupas e penteado de Vincent ressaltando elementos de um futuro retrógrado [5 $\min 34 \mathrm{~s}$ ].

Fonte: Gattaca (1997).

Andrew Niccol também empregou elementos da linguagem cinematográfica para ressaltar a grandeza e poderio da Ciência perante as pessoas. No Fotograma 3, Gattaca é vista de forma grandiosa, sugerindo que sua influência é notável diante da pequenez dos personagens ${ }^{7}$. Niccol foi, assim, capaz de ilustrar, por meio apenas do emprego de um plano específico de filmagem, uma série de simbolismos relacionados com o papel da instituição e, de forma complementar, da incapacidade dos dois personagens ali colocados de questioná-la.

7 Para outras informações referentes à constituição dos elementos cinematográficos, como eles dialogam com os espectadores, ou até mesmo uma análise mais completa do filme Gattaca - A experiência genética, consultar: Sousa (2016). 


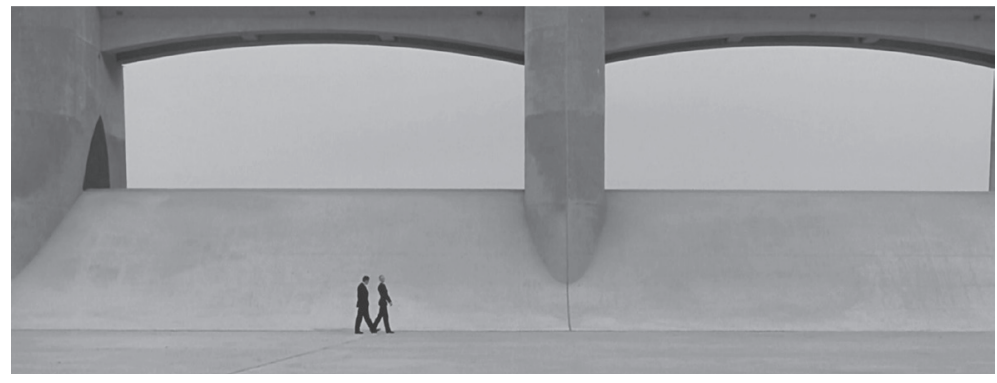

Fotograma 3 - A pequenez ressaltada pelo emprego do plano geral [49 $\mathrm{min} 50 \mathrm{~s}$ ]

Fonte: Gattaca (1997).

\section{O preço do amanhã}

Como seria nossa sociedade se o tempo fosse uma moeda negociável e conquistada a partir do trabalho? E se essa moeda, além de ser utilizada para pagamentos de alugueis, contas de luz e outros, fosse o tempo de vida das pessoas? Nesta outra obra de Andrew Niccol, O preço do amanhã (2011), novamente temos uma sociedade com valores transformados, em que o tempo é o meio de sobrevivência em vigor. Os personagens são modificados geneticamente para envelhecerem até os 25 anos de idade, a partir da qual devem trabalhar para ganhar mais anos de vida.

Will Sallas (Justin Timberlake) é um trabalhador comum que mora na comunidade denominada "gueto", de pessoas de baixa renda social que têm seus tempos bem limitados. Para que eles consigam tempo para viver, deveriam submeter-se às explorações no trabalho. Os dias de vida de Will eram bem limitados, tendo apenas 24 horas para viver, até encontrar Henry Hamilton (Matt Bomer), magnata cansado de ter uma vida quase eterna e morador da região elitista denominada de New Greenwish. Após ter a vida salva por Will, este decide doá-lo todo seu tempo. Will agora possui mais de um século de vida. 
O cerne da narrativa de $O$ preço do amanhã se concentra na divisão das classes. Os cenários e figurinos do filme parecem ressaltar essa divisão. Enquanto os personagens ricos ocupam lugares refinados e ostentam roupas luxuosas, os pobres do "gueto" sempre estão trajando roupas simples, correndo da casa para o trabalho e vice-versa, pois o tempo para eles é muito valioso.

No filme, Niccol aborda a segregação social utilizando o tempo como capital e, para ressaltar a diferença de classes, ele rodou cenas que enfatizaram o local de trabalho frequentado por Will Sallas, aparentemente a única grande indústria do gueto. No Fotograma 4, vemos os operários em busca da meta diária de produção. Caso eles conseguissem cumprir o objetivo de cada dia, eles ganhariam o tempo completo, caso contrário receberiam apenas uma porcentagem. Podemos notar nessa cena o uso preciso dos figurinos para ressaltar a pobreza dessa parte da população. No Fotograma 5 , visualizamos o lado oposto e mais enfático do ponto de vista do cineasta. Os ricos passavam maior parte do seu tempo frequentando cassinos e promovendo festas em suas casas para esbanjar seu capital e se divertirem.

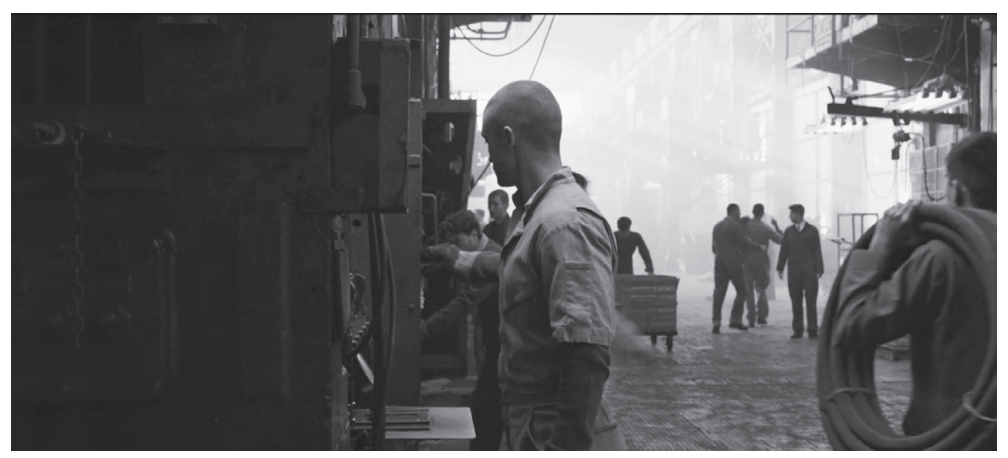

Fotograma 4 - Local de trabalho das pessoas do gueto, onde os figurinos e o cenário destacam a pobreza do local [5 min $10 \mathrm{~s}$ ]. Fonte: O Preço (2011). 


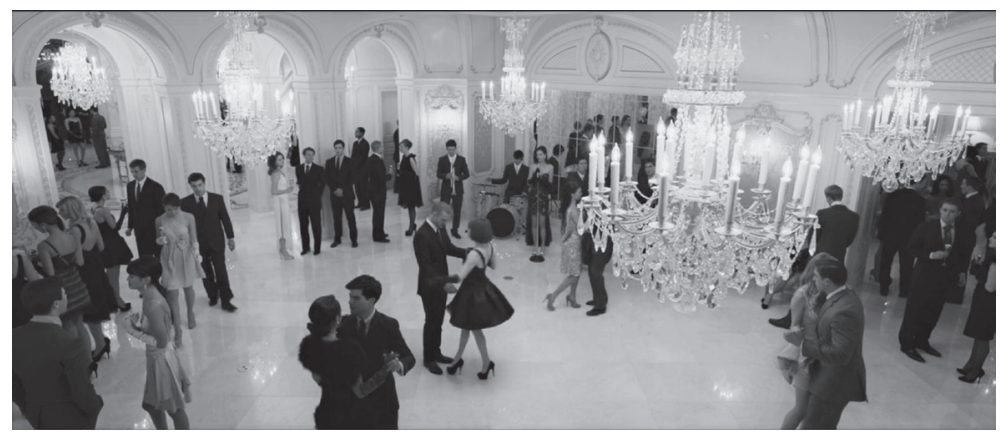

Fotograma 5 - Festa promovida na casa do magnata Philippe Weis (Vincent Kartheiser). Ao contrário do retratado no fotograma anterior, neste temos um cenário luxuoso, com figurinos finos e caros [37 min].

Fonte: O Preço (2011).

\section{Eu, Robô}

O filme dirigido pelo cineasta Alex Proyas (1963-) é mais uma conhecida obra de ficção científica que não economizou criatividade ao construir o futuro de 2035 . Nele vemos grandes obras arquitetônicas futurísticas, estacionamentos para acomodar carros automaticamente, hologramas, automóveis com piloto automático e robôs desempenhando diversas atividades que são executadas por seres humanos na sociedade de hoje. $\mathrm{Na}$ realidade, as únicas heranças de aspectos do passado presentes na obra são a casa do detetive Del Spooner (Will Smith) e as vestimentas que ele utiliza, desde seu toca-fitas até o seu All-Star Vintage de 2004. Nas primeiras aparições do detetive Spooner, é possível perceber o ódio que ele sente dos robôs, resultado de tragédias do passado. Seu real papel dentro da trama será explorar esse ódio e questionar as possibilidades de uma revolução das máquinas, na qual os humanos serão submissos aos robôs e destruídos por eles. 
Quando um dos cientistas e criadores dos androides da U. S. Robotics - maior empresa de produção de robôs no filme - é encontrado morto após cair da janela de seu laboratório, o detetive é convidado a assumir o caso a partir de um holograma feito antes da morte do cientista. Nessa memória, Dr. Alfred Lanning (James Cromwell) fala ao detetive que confiava no julgamento e no questionamento dele sobre os robôs. Então, ao visitar o laboratório do cientista, ele encontrou Sonny, um dos robôs que sofreu um processo de evolução diferentes dos demais, tornando-se uma máquina capaz de sentir medo, ódio e outros sentimentos comuns. Nesse primeiro momento, aos olhos de Spooner, Sonny se tornou o principal suspeito do assassinato do cientista.

Eu, Robô apresentou aos espectadores um futuro promissor para o ano de 2035, no qual o uso de máquinas para facilitar a vida dos seres humanos é comum, desde tarefas domiciliares, entregas por correios, saneamento básico e outras atividades. Na obra, U. S. Robotics é a instituição científica mais bem-sucedida, e é vista pela sociedade como a representação do avanço tecnológico e salvadora da humanidade. Afinal, para muitos personagens, os robôs em Chicago de 2035 substituíam os humanos em inúmeras atividades e, para uma comunidade ociosa que se consolidou no filme, a presença dos androides era inquestionável. No Fotograma 6, Proyas enfatiza o trabalho dos robôs a partir da perspectiva de Spooner e a ociosidade da sociedade. Esses elementos de composição de narrativa e cenários salientam a forma como os seres humanos começaram a se entregar às mordomias e aos grandes feitos da U.S. Robotics, tornando-se acostumados a determinadas regalias. 


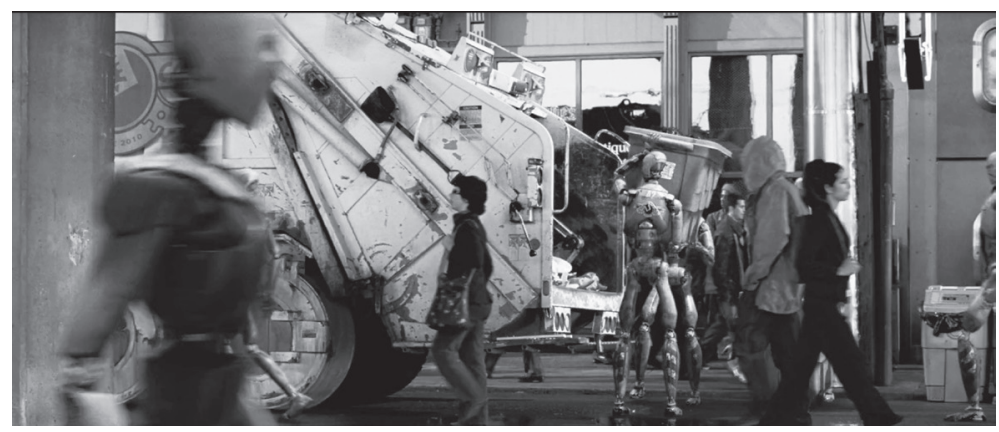

Fotograma 6 - Robôs exercendo tarefa que antes era de humanos [ $3 \mathrm{~min} 55 \mathrm{~s}$ ].

Fonte: Eu (2004).

Para representar a figura rebelde de Spooner, os realizadores investem em roupas "retrô", sugerindo que o personagem de Will Smith não se alinha à ideia de ser rodeado por robôs. Do mesmo modo, sua casa é repleta de "velharias" tecnológicas (Fotograma 7). Para demonstrar o quão Spooner está à parte da sociedade de 2035 , o seu vestuário é fiel ao seu posicionamento contrário à tecnologia. As únicas tecnologias que Spooner usufrui no futuro idealizado pelo cineasta são os carros e os comandos de voz em locais públicos que se tornaram comuns.

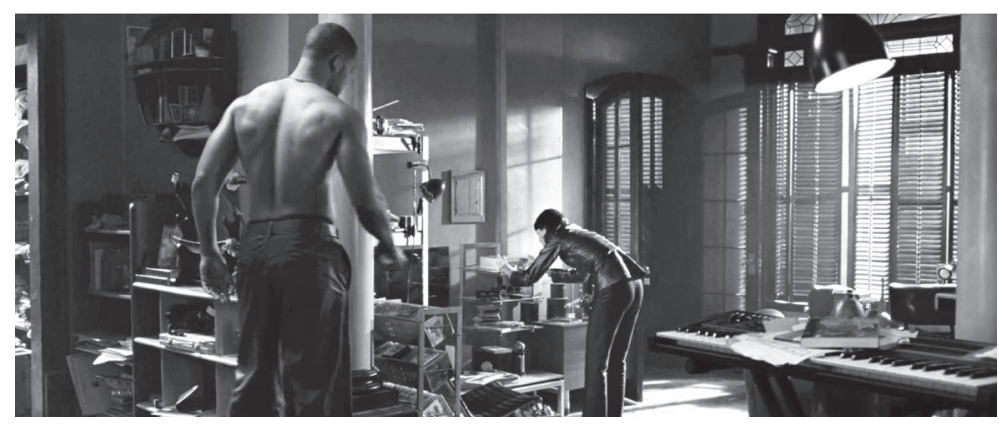

Fotograma 7 - Casa de Spooner [62 min 37 s].

Fonte: $\mathrm{Eu}$ (2004). 


\section{Conclusão}

Neste capítulo, apresentamos como o caráter vilanesco da Ciência também é ressaltado nos filmes a partir do emprego de elementos específicos da linguagem cinematográfica, como planos, angulações, figurinos e cenários. Esses pontos ilustram a grande diversidade de aspectos que cercam uma obra cinematográfica, que geralmente passam despercebidos pelo grande público. Ressaltá-los não só enaltece o filme como revela as inúmeras possibilidades de representar ideias e valores sobre a ciência, além da história em si. Dessa maneira, o professor tem consigo outros recursos para refletir sobre a natureza do conhecimento científico em sala de aula, principalmente sobre as possíveis consequências maléficas da ciência para a sociedade.

No fim, não existe uma Ciência vilã ou salvadora, apenas visões e usos diferentes do conhecimento científico. O caráter humano e social da ciência decide seus fins, para o bem ou mal. Reflexões sobre as visões de Ciência e suas características na perspectiva cinematográfica são importantes para nos posicionarmos criticamente perante ela, pois assim, formaremos cidadãos capazes de compreender mais adequadamente os processos de construção do conhecimento científico.

\section{Referências}

AUMONT, Jacques; MARIE, Michel. Dicionário teórico e crítico de cinema. Tradução de Eloísa Araújo Ribeiro. Papirus: Campinas, 2003.

EU, Robô. Gênero: Fiç̧ão Científica. Direção: Alex Proyas. Roteiro: Akiva Goldsman, Jeff Vintar, Lawrence Konner, Mark Rosenthal. 
Elenco: Alan Tudyk, Bridget Moynahan, Bruce Greenwood, Chi McBride, Will Smith. Produção: John Davis, Laurence Mark, Topher Dow. Fotografia: Simon Duggan. Trilha Sonora: Trevor Jones. Duração: 115 min. Ano: 2004. País: Estados Unidos. Cor: Colorido. Estúdio: Fox. Classificação: Livre.

GATTACA. Gênero: Ficção Científica. Direção: Andrew Niccol. Roteiro: Andrew Niccol. Elenco: Alan Arkin, Elias Koteas, Elizabeth Dennehy, Ernest Borgnine, Ethan Hawke, Gore Vidal, Jayne Brook, Jude Law, Maya Rudolph, Uma Thurman, Vincent Nielson, Xander Berkeley. Produção: Danny DeVito. Fotografia: Slawomir Idziak. Trilha Sonora: Michael Nyman. Duração: 101 min. Ano: 1997. País: Estados Unidos. Cor: Colorido. Estúdio: Columbia Pictures Corporation. Classificação: 14 anos

MARTIN, Marcel. A linguagem cinematográfica. Brasiliense: São Paulo, 2013.

O PREÇO do Amanhã. Gênero: Fiç̧ão Científica. Direção: Andrew Niccol. Roteiro: Andrew Niccol. Elenco: Aaron Perilo, Abhi Sinha, Adam Jamal Craig, Alex Pettyfer, Amanda Seyfried, Andreas Wigand, August Emerson, Bella Heathcote, Blake Sheldon, Brendan Miller, Cathy Baron, Christiann Castellanos, Cillian Murphy, Collins Pennie, Drew James, Emma Fitzpatrick, Ethan Peck, Faye Kingslee, Germano Sardinha, Jeff Staron, Jesse Lee Soffer, Jessica Parker Kennedy, Johnny Galecki, Justin Timberlake, Korrina Rico, Kris Lemche, Kristopher Higgins, La Monde Byrd, Laura Ashley Samuels, Luis Chávez, Matt Bomer, Matt O'Leary, Maximilian Osinski, Melissa Ordway, Michael William Freeman, Nick Lashaway, Olivia Wilde, Paul David Story, Rachel Roberts, Ray Santiago, Sasha Pivovarova, Seema Lazar, Sterling Sulieman, Swen Temmel, Toby Hemingway, Trever 
O’Brien, Vincent Kartheiser, William Peltz, Yaya DaCosta, Zuleyka Silver. Produção: Andrew Niccol, Eric Newman, Mark Abraham. Fotografia: Roger Deakins. Trilha Sonora: Craig Armstrong. Duração: 112 min. Ano: 2011. País: Estados Unidos. Cor: Colorido. Estúdio: New Regency Pictures; Regency Enterprises; Strike Entertainment. Classificação: 12 anos.

PERKOWITZ, Sidney, Hollywood Science: Movies, Science, and the end of the world. New York: Columbia University Press, 2007.

SOBCHACK, Vivian, Screening Space: The American Science Fiction Films. New Brunswick: Rutgers University Press, 1997.

SOUSA, Aennder Ferreira de. A Linguagem Cinematográfica em Gattaca: o que (mais) os filmes podem ensinar sobre a ciência? 2016. 149 f. Dissertação (Mestrado em Ensino e História das Ciências e da Matemática) - Programa de Pós-Graduação em Ensino, História e Filosofia das Ciências e Matemática, Universidade Federal do ABC, Santo André, 2016.

VANOYE, Francis; GOLIOT-LÉTÉ, Anne. Ensaio sobre análise fímica. Papirus: Campinas, 2013. 


\section{DE VOLTA PARA O FUTURO: A VISÃO DE CIENTISTA NO CINEMA}

Suseli de Paula Vissicaro Márcia Helena Alvim

\section{Introdução}

Vivemos numa sociedade em que a Ciência e a tecnologia se fazem cada vez mais presentes na vida cotidiana, adentrando diariamente nas residências por intermédio dos diferentes meios de comunicação: jornais, revistas, programas de televisão ou de rádio, entre outros. Inúmeros são os assuntos que a envolvem e nos convidam à participação, tanto nas discussões públicas como na tomada de decisões. A Ciência deixou de ser um assunto meramente de cientistas.

A facilidade do acesso à informação e o fato de estarmos conectados 24 horas por dia na internet nos permitem, "[...] em qualquer local, recolher informação sobre qualquer assunto em poucos minutos, mudaram de fato a nossa forma de viver" (GOLDSCHMIDT; GOLDSCHMIDT JÚNIOR; LORETO, 2014, p. 134). Nesse acesso irrestrito à informação, diferentes visões de Ciência e de cientista nos são apresentadas pelas diferentes mídias. "Algumas destas visões se afastam da prática científica, 
mas encontram-se incorporadas ao imaginário científico popular", influenciando as práticas educativas, podendo transmitir [...] visões da Ciência que se afastam notoriamente da forma como se constrói o conhecimento científico" (GOLDSCHMIDT; GOLDSCHMIDT JÚNIOR; LORETO, 2014, p. 134).

A visão tradicional sobre a Ciência comumente veiculada, sobretudo nos materiais didáticos, a apresenta como uma atividade neutra, atemporal e livre de pressões de natureza política, econômica ou social. Numa certa caricatura, uma Ciência feita por alguns poucos gênios, que buscam a verdade e utilizam um método científico, único e infalível.

No entanto, essa visão vem sofrendo modificações a partir dos estudos intensificados na década de 1970 (atualmente desdobrados e conhecidos como "Estudos Sociais da Ciência e da Tecnologia"), que situam a Ciência como um produto cultural, resultante de um processo, em outras palavras, ciência como cultura, uma "[...] construção humana sobre os fenômenos do mundo natural a partir de elementos de seu universo cultural, possuindo uma relação dialógica com a sociedade em que é produzida, pois a Ciência sofre e exerce impactos sócio-político-econômicos e culturais na mesma" (ALVIM, 2012, p. 3).

Essa visão tradicional persiste, especialmente no ambiente escolar e nas mídias, influenciando a percepção pública sobre a Ciência e o cientista, como pode ser observado nos filmes e nas falas dos alunos, quando o tema é abordado. A este respeito, Carretero (1993 apud GOLDSCHMIDT; GOLDSCHMIDT JÚNIOR; LORETO, 2014, p. 134-135) ressalta que "[...] os alunos trazem para a sala de aula teorias e explicações sobre o seu cotidiano oriundas de várias fontes, tais como conversas com amigos, familiares, mídia, contextos social e cultural, entre outras". E completa, destacando que essas teorias e explicações, 
além do caráter espontâneo que apresentam, são "extremamente resistentes".

Acerca dessas teorias e explicações trazidas para a sala de aula, diferentes estudos, entre eles o de Gil-Pérez et al. (2001, p. 126), pontuam que não apenas alunos, mas também professores, apresentam certas visões, denominadas pelo autor como deformadas, acerca da Ciência, do trabalho científico e de como se "constroem e se produzem conhecimentos científicos". Essas visões deformadas, quando transmitidas pelo professor, contribuem e reforçam a visão presente nas diferentes esferas e mídias, contudo, convém destacar que elas nem sempre foram as mesmas. Estudos apontam que as visões sobre a Ciência e o cientista em filmes cinematográficos variam, refletindo o contexto no qual os mesmos foram produzidos, como veremos no presente artigo.

Deste modo, este texto irá apresentar uma análise sobre a visão de cientista e Ciência veiculada no filme De volta para o futuro, apresentando possibilidades pedagógicas para professores de Ciências, numa perspectiva de educação científica crítica e reflexiva por meio de discussões sobre a natureza da Ciência em filmes cinematográficos.

\section{Ciência e Cinema}

As relações entre a Ciência e o Cinema são antigas, sendo atribuído a Thomas Alva Edson (1847-1931) a iniciativa de juntar os conhecimentos científicos existentes no final do século XIX "para criar, em seu laboratório, o cinetoscópio ${ }^{1}$ Edson"

1 O cinetoscópio de Edson era "uma espécie de caixa metálica, com uma fonte de luz e um visor, através do qual uma primitiva fita passava à razão de 46 imagens por segundo, gerando a sensação de movimento" (BARCA, 2005, p. 32). 
(BARCA, 2005, p. 32), antes mesmo da invenção do cinematógrafo $^{2}$ pelos irmãos Lumiére. O primeiro filme de ficção científica da história, o curta metragem Le Voyage dans la lune (Viagem à Lua), de 1902, de Georges Méliès, foi também a primeira obra cinematográfica em que apareceram "[...] as primeiras representações de cientistas no cinema, ainda que inspiradas em um romance de ficção" de Júlio Verne (CUNHA; GIORDAN, 2009, p. 10). Misturando animação, comédia e curiosidade científica, Méliès apresenta cientistas semelhantes a magos e feiticeiros (BARCA, 2005). Depois deste, muitos outros filmes "[...] foram produzidos e contribuíram para povoar o imaginário das pessoas, colaborando para construção de uma imagem pública da Ciência e dos cientistas" (CUNHA; GIORDAN, 2009, p. 10), servindo como veículo de divulgação dos avanços da Ciência (OLIVEIRA, 2006).

Segundo Barca (2005, p. 33), “[...] a maioria da população forma suas impressões sobre a Ciência e os cientistas a partir do que veem na mídia, seja nos noticiários, seja em programas de entretenimento, como filmes e novelas". Isso porque "[...] o modo como cada filme é concebido e a época em que ele é realizado têm reflexos diretos na forma como o indivíduo produz os significados e, portanto, na formação de seu pensamento" (CUNHA; GIORDAN, 2009, p. 14). Em outras palavras, o filme reflete em sua concepção o contexto no qual foi produzido, "[...] transmitindo a visão da sociedade ou, pelo menos, de um determinado segmento da sociedade sobre os temas que aborda" (BARCA, 2005, p. 33), e que influenciam a percepção do indivíduo.

Mas, quais seriam essas visões de Ciência e cientista veiculadas pelo Cinema?

2 O cinematógrafo era uma mistura de máquina de filmar e projetor de Cinema. 
No estudo realizado pelo sociólogo Andrew Tudor (1989) e publicado no livro Monsters and mad scientists: a cultural history of horror movie (Monstros e cientistas loucos: uma história cultural dos filmes de terror), é possível observar que a imagem do cientista se modifica entre as décadas de 1930 e 1980 . Segundo o sociólogo (1989 apud BARCA, 2005, p. 33), de mil filmes analisados, em 264, "[...] a ciência é a principal promotora de ameaças à humanidade". Em outros 169 filmes a origem de todos os problemas seria um cientista louco, e "[...] nos 95 restantes, as ameaças não são ocasionadas pela ação direta do cientista, mas são consequências das investigações e descobertas científicas" (BARCA, 2005, p. 33).

Em outras palavras, as imagens dos cientistas variaram do louco aos "[...] homens vivos, inteligentes e respeitáveis produtores de conhecimento por trás dos feitos militares", até papéis secundários, nos quais os acidentes ganham destaque. De acordo com Tudor (apud BARCA, 2005, p. 33), “[...] demorou cinquenta anos para que a maioria das pessoas deixasse de idealizar e ao mesmo tempo temer o cientista, como se fosse uma espécie de bruxo". Assim, a década de 1980 é marcada por uma nova visão de cientista, na qual este assume o papel de herói e aventureiro "[...] que utiliza seus conhecimentos para resolver mistérios e salvar o mundo. É também o professor fascinante que desperta paixões nos alunos, principalmente nas alunas" (BARCA, 2005, p. 36).

Foi nesse período que surgiu a trilogia De volta para o futuro, "[...] que nos mostrava um novo tempo cheio de máquinas e hologramas e nos fazia pensar sobre o futuro e o passado por meio de universos paralelos: um encantamento aos adolescentes e jovens da época" (BARBOSA; BAZZO, 2013, p. 150). Neste filme, o cientista é apresentado como genial e atrapalhado, que 
descobriu sozinho o segredo do tempo e "[...] que faz experiências divertidas e bastante arriscadas, mas que sempre aparece no momento certo para evitar consequências de maior gravidade para o seu jovem amigo e cobaia" (BARCA, 2005, p. 36). Esse filme do diretor Robert Zemeckis entrou para o rol das comédias de maior bilheteria do Cinema, ao mesmo tempo em que reforçava a ideia do cientista louco e genial.

A exemplo do que aconteceu com a literatura, a ficção científica em filme se tornou um gênero popular. Os cientistas conquistaram a simpatia do público como heróis aloprados e divertidos, sempre empenhados em novas experiências, que quase nunca dão certo. (BARCA, 2005, p. 36).

A pesquisa de Tudor, realizada com uma amostragem de mil filmes, demonstra a diversidade de papéis que representaram o cientista no Cinema num determinado período de tempo. Acreditamos que tais filmes certamente influenciaram e ainda influenciam a percepção pública sobre a Ciência e também as representações da sociedade sobre os cientistas. No presente capítulo, não buscamos aprofundar a análise sobre a visão de Ciência e cientista em cada período como Tudor faz; mas, procuramos reconstruir o contexto no qual o filme De volta para o futuro (1985) foi feito e seu potencial para analisarmos a visão de Ciência e cientista veiculada nos filmes cinematográficos.

\section{De volta para o futuro e a percepção sobre Ciência e cientista}

O filme narra a história de Marty McFly, um típico adolescente americano que frequenta o ensino médio, e sua amizade 
com o Dr. Brown, um excêntrico cientista. Ao chegar pela quarta vez atrasado à escola, Marty ouve do diretor que o Dr. Emmet Brown (Doc) é perigoso, um maluco, e o alerta para os problemas que poderia ter ao ser amigo do doutor.

No filme, o Dr. Brown pede que Marty o encontre no estacionamento do shopping da cidade e que leve a câmera de vídeo. Ao chegar ao local combinado, Marty vê Doc saindo de um caminhão com um DeLorean, numa versão modificada e futurista, com sua última experiência. Nesta cena, Doc realiza a experiência de viagem no tempo utilizando o carro. Tudo é registrado pelos olhos atentos de Marty, que filma todo o evento, sem acreditar no que vê. Questionado sobre o que aconteceu com o carro e o cachorro Einstein, Doc explica que ele (o cachorro) é o primeiro viajante no tempo, indo para o futuro, e que o carro é uma máquina de viagem no tempo.

Na sequência, com o retorno do cão, Doc explica a Marty o que aconteceu e como funciona. Nesta cena, o cientista aparece usando um macacão branco, com o símbolo da radioatividade estampado nas costas e usando um cinto com algumas ferramentas e seu cabelo aparece despenteado. No filme, a data 5 de novembro de 1955 é importante para a Ciência, pois, segundo Doc, foi o dia em que ele inventou um dispositivo que possibilitaria a viagem no tempo, após bater a cabeça e ter uma visão: o "capacitador de fluxo", que demorou 30 anos para ser transformado em realidade. É um carro elétrico, mas que usa plutônio para gerar a eletricidade necessária para funcionar, por meio de uma reação nuclear.

Explicações à parte, o filme continua, com Marty entrando no carro para fugir dos líbios, de quem Doc roubou o plutônio que seria utilizado para fazer uma bomba, e chegando à referida data, novembro de 1955, conhecendo seus futuros pais e seu 
amigo cientista. Nesse pequeno trecho, podemos perceber a visão de cientista veiculada pelo filme: temos o cientista inventor, com ideias futuristas, mas apresentado como louco, que inventa a viagem no tempo após bater sua cabeça. Suas roupas e sua aparência reforçam essa visão.

Traçando um paralelo com os dias atuais, esta imagem de cientista nos filmes comerciais está perdendo espaço, mas ela ainda persiste nos filmes e animações infantis, como em Meu Malvado favorito ou Tá chovendo hambúrguer, para citarmos alguns exemplos. Tais filmes associam a imagem do cientista ao pesquisador do sexo masculino, sempre inteligente, que utiliza a criatividade para resolver problemas cotidianos ou mesmo realizar certos feitos tidos como impossíveis, relacionando Ciência a laboratórios e experimentos.

Os cientistas no Cinema são sempre retratados como personalidades solitárias, como o Dr. Brown, o que perpetua a ideia de

[...] uma visão individualista da Ciência, em que os conhecimentos científicos aparecem como obras de gênios isolados, sendo exclusivos do sexo masculino. [...]. Essa imagem estereotipada do cientista e da Ciência veiculada na mídia, [...] pode gerar um afastamento e certo preconceito por parte dos alunos em relação à disciplina e ao professor de Ciências, o que acaba por dificultar o trabalho de construção do conhecimento científico em sala de aula. (GOLDSCHMIDT; GOLDSCHMIDT JÚNIOR; LORETO, 2014, p. 137).

Para Cachapuz (2005 apud GOLDSCHMIDT; GOLDSCHMIDT JÚNIOR; LORETO, 2014, p. 137), essas visões empobrecidas acabam por criar o desinteresse e até mesmo a rejeição a este conhecimento por parte do aluno, convertendo-se em 
obstáculos à aprendizagem, cabendo ao professor, "[...] a tarefa de questionar as diversas visões de Ciências que são veiculadas nos meios de comunicação, de forma a levar o aluno à reflexão sobre o papel da ciência em sua vida".

A interação e mediação do professor são fundamentais nesse processo de reflexão e desconstrução, objetivando promover uma aprendizagem significativa sobre o tema. Isto porque,

A educação em ciências enfrenta um desafio contemporâneo, ela deve contribuir para que o cidadão estabeleça uma relação crítica com a ciência e a tecnologia, relação que seja um antídoto ao ceticismo que idolatra e mitifica a ciência [...] Este desafio guarda correlação com a necessidade de que esse cidadão compreenda a ciência como parte do legado cultural. (MESQUITA, 2008 apud SILVA et al., 2002, p. 2).

Dessa forma, precisamos problematizar e apresentar visões mais próximas da realidade da atividade do cientista e de como este realiza suas pesquisas e onde as faz, haja vista que diferentes cientistas trabalham em diferentes locais, nem sempre em laboratórios.

Por fim, outros pontos ao longo do filme podem ser problematizados, mas, de maneira geral, a película reforça uma imagem tradicional da atividade cientifica e da genialidade do cientista, como um homem à frente de seu tempo e maluco, simultaneamente. Por isso, o filme pode se apresentar como uma excelente oportunidade didática ao professor, por meio de atividades orientadas após a exibição do filme ou promovendo debates a partir de extratos selecionados. As propostas didáticas são variadas e, neste texto, não pretendemos discuti-las, mas sim indicar caminhos para o uso pedagógico desse importante veículo reflexivo. 


\section{Considerações finais}

Como obra artística, não temos a pretensão de ensinar didaticamente conteúdos pré-estabelecidos através dos filmes, mas problematizá-los. Além de ser, segundo Braga, Guerra e Reis (2007, p. 7), "um ponto de partida gerador de debates e aprendizagens de múltiplos conteúdos", o filme também pode ser utilizado como uma nova forma de abordagem das disciplinas.

Mais do que um suporte, os filmes comerciais podem constituir-se em importantes elementos para discussão acerca da ciência e da atividade científica, por apresentarem concepções que podem ser problematizadas, principalmente sobre o cientista, que aparece retratado de maneira sempre estereotipada ao longo da história do Cinema. Tais concepções refletem a visão da sociedade ou de determinado grupo sobre o tema, bem como o contexto em que foi feito, influenciando na percepção do indivíduo e na imagem que este constrói, ainda que o objetivo dos filmes comerciais seja o entretenimento e o lazer.

Visões tradicionais influenciam diretamente na percepção pública sobre a Ciência, e cabe ao professor conhecer essas visões e mediar discussões que visem desconstruí-las, colaborando para a "[...] decodificação dos interesses sociais presentes na construção das imagens fílmicas, abrindo horizontes para a sua ressignificação" (BARBOSA; BAZZO, 2013, p. 152). Assim, ao promovermos ações pedagógicas que busquem analisar essas visões, contribuímos para a formação crítica e para uma educação que privilegie a cidadania e a reflexão.

\section{Referências}

ALVIM, Marcia H. História das Ciências e Ensino de Ciências: potencialidades para uma educação cidadã. In: SEMINARIO 
IBÉRICO, 7.; SEMINARIO IBEROAMERICANO CTS, 3. "CIENCIA, TECNOLOGÍA Y SOCIEDAD EN EL FUTURO DE LA ENSEÑANZA DE LAS CIENCIAS", 28-30 sep. 2012, Madri. Anais... Madri: AECID, 2012. p. 1-8.

BARBOSA, Leila Cristina Aoyama; BAZZO, Walter Antonio. O uso de documentários para o debate ciência-tecnologia-sociedade (CTS) em sala de aula. Revista Ensaio, Belo Horizonte, v. 15, n. 3 , p. 149-161, set./dez. 2013.

BARCA, Lacy. As múltiplas imagens do cientista no cinema. Comunicação \& Educação, ano X, n. 1, p. 31-39, jan./abr. 2005.

BRAGA, Marco; GUERRA, Andréia; REIS, José Cláudio. Cinema e História da Ciência na formação de professores. In: Simpósio Nacional de Ensino de Física, 16., 24-28 jan. 2005, Rio de Janeiro. Anais eletrônicos... Rio de Janeiro: Sociedade Brasileira de Física, 2005. Disponível em: <http://www.sbf1.sbfisica.org.br/eventos/ snef/xvii/sys/resumos/T0147-1.pdf>. Acesso em: 8 jan. 2016.

CUNHA, Marcia Borin da; GIORDAN, Marcelo. A imagem da ciência no cinema. Química Nova na Escola, v. 31, n. 1, p. 9-17, 2009.

DE VOLTA para o futuro. Gênero: Ficção Científica. Direção: Robert Zemeckis. Roteiro: Bob Gale, Robert Zemeckis. Elenco: Billy Zane, Casey Siemaszko, Christopher Lloyd, Claudia Wells, Courtney Gains, Crispin Glover, Cristen Kauffman, David Harold Brown, Donald Fullilove, Elsa Raven, Frances Lee McCain, Gary Riley, George "Buck" Flower, George DiCenzo, Granville "Danny" Young, Harry Waters Jr., Ivy Bethune, J. J. Cohen, James Tolkan, Jamie Abbott, Jason Hervey, Jason Marin, Jeff O'Haco, Johnny Green, Karen Petrasek, Katherine Britton, Lea Thompson, Lee 
Brownfield, Lisa Freeman, Lloyd L. Tolbert, Maia Brewton, Marc McClure, Michael J. Fox, Norman Alden, Paul Hanson, Read Morgan, Richard L. Duran, Robert DeLapp, Robert Krantz, Sachi Parker, Thomas F. Wilson, Tommy Thomas, Wendie Jo Sperber, Will Hare. Produção: Bob Gale, Neil Canton. Fotografia: Dean Cundey. Trilha Sonora: Alan Silvestri. Duração: 116 min. Ano: 1985. País: Estados Unidos. Cor: Colorido. Estúdio: Amblin Entertainment; Universal Pictures. Classificação: Livre.

GIL-PÉREZ, Daniel; MONTORO, Isabel Fernández; ALÍS, Jaime Carrascosa; CACHAPUZ, António; PRAIA, João Praia. Para uma imagem não deformada do trabalho científico. Ciência \& Educação, v. 7, n. 2, p. 125-153, 2001.

GOLDSCHMIDT, Andrea Inês; GOLDSCHMIDT JÚNIOR, José Luiz; LORETO, Élgion Lúcio da Silva. Concepções referentes à Ciência e aos cientistas entre alunos de anos iniciais e alunos em formação docente. Contexto \& Educação, ano 29, n. 92, p. 132-64, 2014.

OLIVEIRA, Bernardo Jefferson. Cinema e imaginário científico. História, Ciências, Saúde-Manguinhos, v. 13 (suplemento), p. 133-150, out. 2006.

SILVA, Kathya Rogéria; GASPARRINI, Lázaro José; SILVA, Lilian Rogéria; CUNHA, Marcia Borin. Percepções de cientista no filme "Os Smurfs": uma experiência em sala de aula. In: ENCONTRO NACIONAL DE ENSINO DE QUÍMICA, 16., Salvador, 17-20 jul. 2012. Anais eletrônicos... Salvador: UFBA, 2012. Disponível em: <http://www.portalseer.ufba.br/index.php/anaiseneq2012/ article/view/7442>. Acesso em: 10 mar. 2016. 


\section{FRANCIS BACON E A CONSTITUIÇÃO DO IDEAL CIENTÍFICO MODERNO}

Luciana Zaterka

Guilherme de Lucas A. Barbosa

\section{Introdução}

Poucos são os homens e as mulheres que veem na expressão mesma da morte a representação plena de uma motivação de vida. Talvez o caso de Sir Francis Bacon (1561-1626) seja uma exceção. A maioria dos seus comentadores assinala a sua morte apenas como um episódio curioso, dentre tantos outros acontecimentos que conduziram a vida e as ideias desse pensador seiscentista. Contudo, Bacon nasceu, cresceu e viveu acreditando em suas máximas teóricas, dentre elas a de que o "saber é poder". Assim, não seria em seu leito de morte que abandonaria as bases de sua filosofia. Pois que, no ano de 1626, o filósofo inglês morreu vítima de uma bronquite contraída devido às experiências feitas no inverno londrino com neve, quando especialmente se questionava se o congelamento teria a propriedade de conservação das carnes frescas ${ }^{1}$.

1 "O Sr. Hobbes me disse que a causa da morte de vossa Senhoria foi a tentativa de fazer um experimento; isto é, como ele estava tomando ar em uma 
Mas, afinal, quem foi Francis Bacon? Filósofo natural que se ocupou de inúmeras questões: de direito, de filosofia, de política, epistêmicas, científicas, morais. Assinalado por alguns como o "pai da ciência moderna", por outros como o "último renascentista", por fim uma "figura polêmica" que talvez não mereça nenhum desses títulos, pois não criou nada de concreto, como uma máquina, um fármaco, ou uma substância. No máximo pode ser visto como aquele que auxiliou a criar a metodologia indutiva moderna. Porém, se nosso pensador é um "antigo ou um moderno", essa questão não se coloca para nós, questão ultrapassada pela historiografia da história da ciência contemporânea (ALFONSO-GOLDFARB; BELTRAN, 2004). O importante é que, pelo seu empreendimento filosófico, bem como pelo seu legado, podemos notar a construção de uma ciência humanista, permeada por valores éticos e teológicos, que, acima de tudo, deveria assumir um papel central para o melhoramento da vida de todos os indivíduos de uma dada sociedade.

\section{A grande instauração}

Francis Bacon nasceu no dia 22 de janeiro de 1561, foi o 8 filho de Sir Nicholas Bacon e de Anna Cook. Nicholas era funcionário da corte da Rainha Elizabeth I, empenhou-se em educar o filho na carreira política e diplomática. A mãe, mulher culta e pacata, cuja expressão máxima seria a alta religiosidade, obrigara o jovem Francis a ter contanto, desde então, com

carruagem com o Dr. Witherborne em direção a Highgate, a neve cobria o chão, e ela veio nos pensamentos dele, porque a carne fresca não poderia ser preservada pela neve, como ocorre com o sal? Eles resolveram que iriam testar o experimento de uma só vez. [...] A neve o refrigerou, que vossa Senhoria imediatamente caiu muito doente, que não pode voltar mais para a sua hospedagem" (AUBREY, 1982, p. 29). 
o ensino religioso. Aqui já podemos notar a base mesma de aspectos importantes de sua vida e obra. De um lado, o interesse sempre presente pelas questões políticas e morais. Por outro, a religiosidade que perpassa boa parte de sua obra. Com relação aos primeiros interesses, Bacon, após ter estudado no Trinity College, cursou direito no Grey's Inn. Já em 1584, foi eleito deputado para o parlamento inglês. Sua carreira política continuou ascendente até que atingiu o mais alto cargo político da época: tornou-se Lord Chanceler em 1618, e usufruiu, então, de altas honrarias no reino britânico.

Assim como a maioria dos homens poderosos, Bacon nutria inimizades no reino. Seu nome foi, assim, envolvido em escândalos de corrupção pautados no recebimento de presentes. Confessou a infração e foi preso. O Rei Jaime I intercedeu em sua causa e o libertou, embora não tenha evitado que o seu cargo e títulos fossem retirados no ano de $1621^{2}$. Esse interesse por questões políticas e morais foi, em parte, compartilhado no seu importante Essays, publicado em 1597, em sua primeira

\footnotetext{
2 Segundo Markku Peltonen (1996, p. 12): "No final do ano de 1620, Bacon estava no auge de sua carreira. Em outubro tinha publicado o Novum Organum e em janeiro recebeu o título de Visconde de St. Albans. Ao mesmo tempo, estava bastante empenhado num trabalho preliminar para o novo parlamento. Este Parlamento foi instituído em 30 de janeiro de 1621, e Bacon assumiu o seu lugar na Câmara dos Lordes. Bacon já possuía 40 anos de experiência na Câmara dos Comuns, mas esta foi a primeira vez que assumiu a dos Lordes. Foi para ele um parlamento fatal. Dentro de poucas semanas, ele recebeu acusações de corrupção (ele tinha aceitado presentes de dois homens cujos casos ele havia defendido no tribunal) e no dia 3 de maio foi removido pela Alta Corte do Parlamento, tendo confessado a sua culpa. Bacon não foi impugnado por causa dos presentes que recebera. Ao contrário, foi vítima de uma campanha política dirigida contra os monopólios e o chefe favorito do rei Buckingham. Ele foi preso pelo rei (detido efetivamente apenas por três dias), pagou uma multa de 40 mil libras, foi impedido de assumir qualquer emprego no estado e proibido de sentar novamente no parlamento ou passar pelas redondezas (doze milhas) do tribunal".
} 
edição, e nas obras de teor mais jurídico The Elements of the common Lawes of England (1630), Cases of treason (1641), The learned Reading of Sir Francis Bacon upon the statute of uses (1642).

Com relação às suas bases religiosas, muito pode ser dito. Bacon foi, acima de tudo, um cristão virtuoso, isto é, um filósofo natural cristão, que construiu seu empreendimento filosófico levando em consideração o plano divino da criação, o bem-estar do próximo e, é claro, a estrutura do mundo natural. Por meio do estudo da natureza, ele acreditava poder descobrir constantemente novas maravilhas que suscitavam o amor pelo ser divino; no limite, a cada nova descoberta ele se sentia mais próximo de Deus: "Onde quer que seus estudos os conduzissem, eles [os virtuosos] encontravam-se seguindo as pegadas de Deus; o céu declara a Glória de Deus; e o firmamento revela Sua obra" (WESTFALL, 1958, p. 26).

De fato, as bases da ciência instituída por Bacon só fazem sentido se não perdemos de vista esse pressuposto teológico. Tanto é assim que nosso pensador intitula a sua principal obra como Instauratio Magna, isto é, "uma grandiosa restauração do saber e da ciência"'3 (BACON, 1979, p. 9). Nesse sentido, a reforma do conhecimento pretende substituir a ciência aristotélica contemplativa, fundada sobre palavras vazias, sobre silogismos tautológicos e inúteis e sobre autoridades e dogmas - por uma nova concepção de ciência operativa:

O silogismo consta de proposições, as proposições de palavras, as palavras são os símbolos das noções.

${ }^{3}$ Cf. prefácio do Novum Organum, de 1620. 
Pelo que, se as próprias noções (que são a base da realidade) são confusas e precipitadamente abstraídas dos fatos, não pode haver solidez no que se constrói sobre elas. Aqui está por que a única esperança está na verdadeira indução. (BACON, 1979, Novum Organum, p. 15).

Essa restauração ou instauração será, então, o grande objetivo do empreendimento baconiano. Instauratio compreende uma ampla gama de significados. Além de possuir um sentido político, qual seja, um projeto público, coletivo e financiável, possuir um sentido histórico, isto é, um empreendimento que não pode mais se fixar no passado, nos livros das autoridades, mas deve se voltar para o futuro, possui um sentido religioso preciso ${ }^{4}$.

Pois o homem, pela Queda caiu ao mesmo tempo de seu estado de inocência e de seu domínio sobre a criação. Ambas as perdas, contudo, podem ser em parte remediadas ainda nesta vida; a primeira, pela

\footnotetext{
4 De fato, encontramos na obra baconiana, como nos lembra Paolo Rossi, uma série de referências ao texto bíblico e uma ampla simbologia extraída do Antigo e do Novo Testamento: "O título do Temporis partus masculus, sive instauratio magna imperii humani in universum faz referência à grande promessa do Gênese; a terceira parte da Instauratio, concernente à preparação da história natural, era designada por Bacon pelo termo Parasceve, que indica, no Novo Testamento, o dia de preparação para o sábado hebraico; Bensalem é o nome da ilha da Nova Atlântida, e a grande fundação que é dedicada ao estudo das obras e das criaturas de Deus chama-se Casa de Salomão ou Colégio das Obras dos Seis Dias [...]. Trata-se, sobretudo, de levar em conta duas coisas: em primeiro lugar, o fato de que a recusa baconiana da cultura grega e da filosofia escolástica nasceu no plano de uma condenação moral, de uma acusação de impiedade religiosa e de uma contraposição da Bíblia à filosofia de Aristóteles; em segundo lugar, o fato de que a reforma do saber, pela qual Bacon trabalhou incansavelmente, foi por ele conscientemente inserida no grande esquema teológico do pecado, da expiação e da redenção" (ROSSI, 1992, p. 63).
} 
religião e fé, a última pelas artes e ciências. (BACON, 1979, Novum Organum, p. 230).

Observamos aqui que a instauratio diz respeito à restauração do conhecimento que o homem possuía antes do pecado original, quando tínhamos a capacidade de "refletir plenamente a natureza". Ora, com a Queda houve uma interrupção desta habilidade que possuíamos sobre os fenômenos da natureza, cabe, agora, retomarmos essa capacidade por meio de uma nova concepção de Ciência, ciência adequadamente conduzida, o que significa uma ciência operativa, experimental e, portanto, indutiva.

Para efetivar o seu projeto, nosso pensador elabora na sua Distributio opera, um plano em seis partes, que resume sua intenção de maneira manifesta. Na primeira parte, intitulada "As Partições das Ciências", Bacon pretende avaliar e classificar o estado da ciência de sua época, e seu diagnóstico é preciso: até então os saberes estavam absolutamente estagnados, baseando-se em dogmas e concepções referendadas por argumentos de autoridades, tais como o aristotelismo e o platonismo. Ora, de agora em diante, será necessário olhar para o futuro e construir uma ciência operativa fundada numa ética social. A verdade deixará de ser "filha da autoridade" e se transformará em "filha do tempo". A segunda parte, a mais desenvolvida pelo filósofo, intitula-se "O Novo Organum ou indicações acerca da interpretação da natureza". Aqui, como o nome sugere, encontramos um novo método, que não mais utiliza a lógica antiga, baseada nos silogismos propostos pelo Organum aristotélico, mas que proceda por meio da "verdadeira indução". Para atingirmos tal objetivo teremos que, inicialmente, nos livrarmos de tudo aquilo que seja um obstáculo ao conhecimento, tudo que se refira aos nossos preconceitos e simulacros, enfim teremos que instituir uma 
crítica aos ídolos 5 . Nesse sentido, será necessário a introdução de instrumentos ou medidas que possam auxiliar a mente humana a se libertar dessas tendências, inclinações e simulacros:

Uma vez estabelecido o escopo da ciência, passamos aos preceitos e na ordem menos sinuosa e obscura possível. E as indicações acerca da interpretação da natureza compreendem duas partes gerais: a primeira, que consiste em estabelecer e fazer surgir os axiomas da experiência; a segunda, em deduzir e derivar experimentos novos dos axiomas. A primeira parte divide-se em três administrações, a saber, administração dos sentidos, administração da memória e administração da mente ou da razão. (BACON, 1979, Novum Organum, p. 102).

Assim, esses instrumentos terão como finalidade auxiliar os sentidos, a memória e o intelecto para que não se percam durante esse novo processo de reforma. Na terceira parte, "Fenômenos do universo, ou história natural e experimental para fundamentar a filosofia", Bacon formula propriamente o seu procedimento científico. A sua proposta filosófico-científica só é possível se original e fundamentalmente construirmos uma história experimental da natureza: "Pois o conhecimento é como uma pirâmide, onde a história é a base; assim, na filosofia natural, a base é a história natural" (BACON, 1963b, p. 356).

Assim, com relação à filosofia natural a base da pirâmide é a história natural, ou seja, a acumulação de todos os dados empíricos que se possam observar, classificar e coletar, bem como

\footnotetext{
5 "São de quatro classes os ídolos (idola) que bloqueiam a mente humana. Para melhor apresentá-los, Ihes assinamos nomes, a saber: Ídolos da Tribo, Ídolos da Caverna, Ídolos do Foro e Ídolos do Teatro" (BACON, 1979, Novum Organum, p. 21).
} 
o registro exaustivo dos mais variados assuntos. É por isso que o pensador inglês escreveu inúmeras "histórias", por exemplo, a do vento (Historia ventorum - 1622), da vida e morte (Historia vitae et mortis - 1623) e do denso e raro (Historia densi et rare 1623). A importância da história natural para o empreendimento baconiano pode ainda ser notada pelo seu Sylva Sylvarum or Natural History in ten Centuries, um livro que é por excelência uma "coleção de coleções". Nesse sentido, em De dignitate et augmentis scientiarum, Bacon afirma:

Dificilmente pode haver qualquer coisa mais útil mesmo para as ciências mais antigas e populares do que uma ajuda segura para a memória; ou seja, um bom e instruído Compêndio de Citações... Eu defendo cuidado e trabalho nas entradas das citações para ser um assunto de grande uso e apoiar o estudo; como que fornecer material para invenção, e ajustar a visão de julgamento... Mas ainda que seja verdade que dos métodos e estruturas das citações que até agora tenho visto não há nenhum de qualquer valor, todos eles carregando em seus títulos meramente a face de uma escola e não de um mundo, e utilizando divisões vulgares e pedantes, não tais como penetrar no âmago e coração das coisas. (BACON, 1963a, p. 435).

Em outras palavras, devemos iniciar a busca pelo conhecimento pela sua fundação, ou seja, "preparar uma História Natural e Experimental, suficiente e boa". A pergunta, então, que poderíamos formular, é: como Bacon sugere que se faça a compilação desses dados, como construir, de fato, uma "boa" História Natural e Experimental da Natureza?

Em Parasceve ad historiam naturalem et experimentalem (1620), ele fornece uma pista: não devemos seguir os modelos de homens como Teofrasto, Dioscórides ou Plínio, pois 
histórias supersticiosas e "simples" descrições de espécies são perda de tempo; devemos, sim, adotar um método mais "quantitativo". De fato, tudo que for relacionado aos corpos e às virtudes da natureza deve ser, tanto quanto possível, numerado, pesado, medido e definido. Deste modo, Bacon vincula claramente a história com o método experimental. Lembremo-nos de que o autor do Novum Organum afirma que as histórias não podem ser meros catálogos de fatos empíricos, nem devem se restringir às coisas imediatamente úteis, mas a história natural deve fornecer luz à descoberta das causas. Tal objetivo, segundo ele, só pode ser atingido se dissecarmos, alterarmos, atormentarmos a natureza por meio de experimentos, pois assim os homens poderão se aproximar das causas escondidas, por meio dos efeitos manifestos observados na natureza.

Dessa perspectiva, a história natural lida principalmente com os constituintes mais fundamentais da natureza. $\mathrm{E}$ o interessante é que Lorde Verulâmio classifica a própria natureza em três estados: os processos naturais (ou gerações), os monstros na natureza (ou preter-geração) e a natureza modificada pelo domínio do homem (ou as artes). Esta última é a natureza confinada, atormentada, modificada por meio de experimentos humanos. Bacon, então, enfatiza o uso da história natural como parte constitutiva da nova filosofia experimental seiscentista inglesa. Tanto é assim que vários homens importantes de ciência ao aderirem ao "programa baconiano", irão inserir a história experimental da natureza como a base de seus respectivos métodos. Escutemos, por exemplo, Robert Hooke (1969, p. 7):

Um método que faz uso... destes meios e auxílios da natureza humana para compilar uma história filosófica; consistindo de uma descrição exata de todos os tipos de operações naturais e artificiais, ou método de 
fazer experimentos e observações para a prossecução e exame de qualquer questão filosófica... Um método para descrever, registrar, e ampliar estes particulares assim coletados, como para se tornarem os materiais mais adaptados para o crescimento de axiomas e aperfeiçoar a filosofia natural.

Na quarta parte, $A$ escada do entendimento, Bacon pretende fornecer um exemplo concreto a respeito das regras já apresentadas. O ponto importante destacado pelo autor é que os homens de ciência, antes de elaborarem suas afirmações "certas e indubitáveis", devem fazer muitos testes. E aqui Bacon constrói as suas tábuas, ou seja, instrumentos que podem auxiliar o intelecto humano na sua busca pelos axiomas ou pelas formas. Nos aforismos 11 a 20 do Livro II do Novum Organum, nosso pensador exemplifica com as tábuas de presença, ausência e de graus sobre a investigação da natureza do calor. Já na quinta parte, intitulada "Precursores, ou antecipações da filosofia segunda", ele apresenta alguns dos primeiros resultados de seu método, a chamada "primeira vindima" ou "primeira colheita"6. É interessante que neste âmbito notamos como a ciência proposta por Bacon deve ser compreendida como processual e histórica, no sentido que devemos sempre testar e avaliar se estamos, de fato, no bom caminho, afinal a trilha do conhecimento é longa e árdua e não podemos nos perder no método proposto. Por fim, a sexta e última parte, "Filosofia segunda ou ciência ativa", apresentaria a ciência baconiana propriamente dita. Mas,

${ }^{6}$ Desta primeira vindima o filósofo conclui "[...] a forma ou verdadeira definição do calor (o calor em relação ao universo e não apenas em relação aos sentidos), pode ser expressa brevemente do seguinte modo: o calor é um movimento expansivo, reprimido e que atua sobre as partículas menores (BACON, 1979, p. 133). 
infelizmente, Bacon não deixou nada escrito sobre este item, e por essa razão foi duramente criticado por seus comentadores. Talvez essas críticas não sejam justas, afinal o modelo claramente proposto por ele se baseia numa obra coletiva e de longa duração. Assim, nosso filósofo indicou o caminho, seus seguidores poderão trilhá-lo e completá-lo, o que aliás foi feito por muitos dos membros da recém fundada Royal Society. A concepção de uma ciência operativa, pública e coletiva estava anunciada.

\section{A filosofia experimental}

O estudo da filosofia baconiana pode nos auxiliar na compreensão de aspectos nucleares do novo quadro de referência filosófico-científico do pensamento moderno, afinal, numa época em que a escolástica tardia ainda fornece o modelo do conhecimento científico dominante, o que significa, para Bacon, definir o homem como ministro e intérprete da natureza ou acreditar que o ideal científico se dá através da alteração sobre a natureza. Como a proposta baconiana se inscreve, como vimos, num projeto de "restauração total dos saberes", Bacon irá redefinir inúmeros dos conceitos filosóficos utilizados até então. Lembremo-nos, por exemplo, das famosas palavras do aforismo III do Livro I do Novum Organum, no qual Bacon (1979, p. 13) menciona que ciência e poder do homem "[...] coincidem, uma vez que, sendo a causa ignorada, frustra-se o efeito. Pois a natureza não se vence, senão quando se lhe obedece. E o que à contemplação apresenta-se como causa é regra na prática".

Para Bacon, o conhecimento da filosofia natural deve incluir necessariamente não só o conhecimento das causas, mas a produção dos mesmos efeitos por meio de nossa intervenção; 
ou seja, "conhecer para dominar a natureza pelo saber" significa, antes de mais nada, transformar o conhecimento em algo útil e proveitoso para a vida dos homens. É nesse mesmo sentido que Galileu, por exemplo, no seu Diálogos sobre os dois principais sistemas do mundo (1632), pede para que engenheiros descrevam o verdadeiro sistema do mundo. Essa atitude, frente aos engenheiros, técnicos, "artesãos", mais do que refletir uma postura somente científica, reflete uma virada de perspectiva frente à tradição na concepção mesma de mundo. De agora em diante "o engenheiro" conquista a dignidade de um sábio, porque a arte de fabricar torna-se o protótipo da ciência. O que comporta, então, uma nova definição de conhecimento, que já não é contemplação, mas utilização, uma nova atitude do homem perante a natureza: ele deixa de simplesmente contemplá-la, para conquistá-la. Essa nova atitude frente à natureza terá consequências importantes.

Por ora, lembremo-nos de que os homens terão que repensar, por exemplo, na dicotomia entre o âmbito laboratorial/ artificial e o natural. A natureza deixará de ser sagrada e, portanto, inimitável. Em outras palavras, as coisas artificiais não diferem das naturais pela forma ou pela essência, mas apenas pela causa eficiente; no limite, os movimentos artificiais não devem ser contrapostos aos naturais. O calor solar pode ser comparado ao fogo, o ouro natural presente na areia é idêntico ao artificialmente produzido nas fornalhas. A física terrestre é idêntica à celeste (ROSSI, 1989). Assim, os homens de ciência não precisam mais temer a cólera divina por manipular, atormentar e alterar a natureza, pois manipular a obra divina é um de seus desígnios.

Por meio desse pano de fundo teórico, podemos notar claramente a crítica que Bacon dirige à tradição. Como a filosofia antiga foi construída por meio de simples discursos e 
palavras, valorizando, assim, as disputas e o tom professoral e autoritário, e não o livro efetivo da natureza, sua construção se baseava em argumentos vazios, distante das observações e experimentações que são necessárias para alcançarmos, de fato, o conhecimento verdadeiro e frutífero dos fenômenos naturais. Ora, a concepção baconiana, ao contrário, propõe uma ênfase nas obras e, portanto, na operacionalidade da natureza.

Gostaríamos aqui de enfatizar dois aspectos que nos parecem importantes. Em primeiro lugar, o significado deste método experimental, já que, sabemos, na Antiguidade, homens como Galeno ou Aristóteles faziam também observações e experiências. Leiamos a esse respeito o aforismo LXXXII da parte I do Novum Organum:

Ademais, o fim e a meta da ciência foram mal postos pelos homens. Mas, ainda que bem postos, a via escolhida é errônea e impérvia. E é de causar estupefação, a quem quer que de ânimo avisado considere a matéria, constatar que nenhum mortal se tenha cuidado ou tentado a peito traçar e estender ao intelecto humano uma via, a partir dos sentidos e da experiência bem fundada, mas que, ao invés, se tenha tudo abandonado ou às trevas da tradição, ou ao vórtice e torvelinho dos argumentos ou, ainda, às flutuações e desvios do acaso e de uma experiência vaga e desregrada (BACON, Novum Organum, 1979, p. 49).

O método deve seguir a experiência bem fundada e não uma experiência vaga ou errática. $E$ aqui chegamos num ponto importante do empreendimento filosófico-científico de Bacon: os experimentos devem ser gerados com ordem, regras, protocolos. Poucas experiências, ou experiências ao acaso, não podem fornecer o resultado esperado. Por quê? Pois o novo método pretende alcançar as propriedades gerais dos corpos. 
Utilizando o método a posteriori, isto é, dos efeitos observados para as causas existentes, podemos nos aproximar da "estrutura interna dos corpos", na terminologia baconiana, nos aproximar das formas ${ }^{7}$. Ora, se essa "estrutura interna" ou essa "forma" é inalcançável, devemos, por meio da nova filosofia natural, buscar os seus processos subjacentes. É por isso que o experimento aparece como instrumento privilegiado. Se alcançarmos algumas das condições necessárias para a produção dos efeitos, o homem já estará fazendo uma ciência útil e, portanto, voltada para o seu bem-estar. Em outras palavras, parece-nos que o alvo é menos o conhecimento das substâncias em geral e mais a transformação de alguns conhecimentos da matéria em poderes humanos.

E chegamos ao nosso segundo ponto. Bem-estar, utilidade, poder, experimento são algumas das palavras-chave para compreendermos aspectos desse projeto moderno. Para atingimos o objetivo proposto, a nova filosofia experimental deve necessariamente abarcar um caráter público, social e financiado. É por isso que, em meados do Seiscentos, observamos o aparecimento das academias científicas, como a Royal Society, bem como o início da institucionalização dos primeiros laboratórios, além, é claro, de uma ampla correspondência entre os homens de ciência publicizando e, portanto, compartilhando as suas ideias, os seus descobrimentos e protocolos. Bacon, como vimos, propõe uma conjunção da filosofia com a técnica, de forma que a especulação e a abstração filosófica viessem ajudar o trabalho técnico e vice-versa, pois nessa confluência todos sairiam ganhando. A humanidade como um todo se beneficiaria

7 Sobre o complexo conceito de forma na filosofia baconiana, ver: Zaterka (2013). 
com o advento desse novo saber operativo e prático. Por isso Bacon tentou convencer o rei e vários homens públicos de que esse era um assunto de interesse nacional, inaugurando a ideia de que o Estado deveria financiar a pesquisa e reformar as instituições de ensino.

Ora, o leit motiv baconiano "saber é poder", apresenta uma concepção de ciência que deve, sobretudo, visar o bem-estar da humanidade e, então, as descobertas feitas pela ciência devem ter como objetivo facilitar a vida humana sobre a Terra. Essa ideia que constitui um dos pilares do ideal científico moderno pode ser compreendida em toda a sua magnitude pela utopia baconiana - a Nova Altântida. Veremos, por meio dela, que talvez o problema do "programa baconiano" não se encontre na sua concepção de base, mas no sucesso excessivo desse ideal, e, portanto, nos seus desdobramentos.

\section{A utopia baconiana}

A utopia, tal como fábula política ilustrada, demonstra os desejos mais poderosos de seu autor por meio de imagens palatáveis de sonhos irrealizáveis ${ }^{8}$. Evidentemente que, ao conceber a sua própria fábula utópica, Lorde Verulâmio a engendraria a partir dos pressupostos que nortearam não apenas a sua vida, mas também toda a sua produção filosófica. Encontramos ali aspectos importantes que perpassam praticamente todo o seu ideário, por exemplo, a religiosidade na instituição clerical de governo, para além dos símbolos e nomenclaturas; e também suas bases sociais, pautadas nas ciências e na tecnologia.

${ }^{8}$ Ver: Chaui (2011, p. 361-386). 
Na prática de sua instauração, tal como os "filósofos-reis" na República de Platão, ele compõe a liderança política desta ilha na instituição científica mais importante: a Casa de Salomão. Aliás, a história deste punhado de terra insular de nome Nova Atlântida se apresenta como algo muito diverso da ideia de Platão, pois nessa espécie de "antirrepública" a felicidade reina por meio de aspectos e organizações que só puderam ser alcançadas junto ao domínio pleno dos segredos da natureza, portanto no âmbito da materialidade e da operacionalidade dos fenômenos naturais.

A obra não foi concluída por Bacon, mas sim por William Rawley, seu assistente pessoal. Rawley tratou de editá-la e apresentá-la em 1624. Na trama, Bensalém (cidade-estado de Nova Atlântida) é descoberta por navegadores perdidos em busca de alcançar a China e o Japão pelo mar do sul. O relato, todo em primeira pessoa, mostra a narrativa do deslumbramento do colonizador europeu que acaba sendo, ele próprio, o "colonizado"9. Os habitantes de Bensalém são cristãos, educados e gozam plenamente das benesses naturais graças ao empenho das ciências e da técnica, da nação insular e de suas lideranças. Assim, problemas sociais são eliminados e o homem pode viver em plena harmonia. Bensalém apresenta concepções já descritas em outras utopias, tal como a de Thomas Morus (A Utopia - 1516) ou a de Tommaso Campanella (Cidade do Sol - 1602).

Interessante observarmos a presença de características sociais e ambientais claramente antagônicas à Europa do Seis-

\footnotetext{
9 Moraes Júnior (2008, p. 13) afirma que estabilidade social, justiça, leis rígidas e justas, limpeza e urbanismo, transparência e coletivismo são algumas das qualificações que Morus e Bacon narram em sua obra, em contraponto à Inglaterra do período. Itens que compõem o imaginário de uma civilização perfeita, que, ao invés de ser colonizada pelo europeu, acabou por colonizá-lo.
} 
centos em todas as camadas ou nichos daquela sociedade. De fato, nessas utopias a geometria e a higiene, esta última no sentido mais amplo do termo, dominavam o ethos social. Entretanto Bensalém possui uma característica que em Amaurota - a utopia moriana - não havia sido explorada, e que tinha sido parcialmente apresentada na Cidade do Sol de Campanella. O conhecimento e o avanço nas ciências, vinculados a uma nova noção de progresso, fazem da Nova Atlântida de Bacon uma importante obra para as futuras utopias após o século XVII; pois a construção dessa modernidade por vias tecnológicas são entrelaçadas nesse livro. E isto será apresentado, desde então, como importante braço usual das histórias de ficção científica atuais: o vínculo entre os benefícios gerados pelos avanços tecnológicos e o progresso da felicidade humana, ao poder usufruir das benesses causadas pelo domínio da natureza e pelo controle de doenças.

Bacon escreve sua utopia enfatizando os avanços tecnológicos de maneira semelhante às encontradas nas ficções científicas: as marcas do império humano são marcas futuristas presentes. A tecnologia funciona como instrumento para a cura de doenças e resolução da pobreza. Sua sociedade "tecnocrata" é representada pela Casa de Salomão:

A finalidade de nossa instituição é o conhecimento das causas e dos segredos dos movimentos das coisas e a ampliação dos limites do império humano para a realização de todas as coisas que forem possíveis. (BACON, Nova Atlântida, 1979, p. 272).

É esse modelo utópico baconiano que irá avançar gradativamente entre os séculos e inspirar inúmeras outras fábulas políticas no decorrer da história, bem como será a base criativa para diversos contos de ficção científica. 


\section{Considerações finais}

O que a Nova Atlântida nos demonstra tacitamente é a efetivação mais ampla do ideal filosófico-científico baconiano, edificado, como vimos, pelo método indutivo e experimental apresentado na Instauratio Magna. A narrativa consolida os desejos de Sir Francis Bacon, cujo progresso da ciência seria responsável por conseguirmos atingir uma vida plena, saudável e, por que não, eterna. Contudo, do ponto de vista contemporâneo, ironicamente, a questão talvez se localize exatamente no sucesso excessivo desse ideal, e, portanto, nos seus desdobramentos. É interessante pensarmos que talvez o "problema" do projeto baconiano não esteja nele mesmo, mas nesse excessivo sucesso:

A fórmula baconiana diz que saber é poder. No entanto, a realização dessa fórmula, no ápice de seu triunfo, tornou manifesta a dialética em que se envolve esse poder: o grau mais avançado de exploração técnica da natureza para sujeição desta à vontade de poder humana revela, sob o signo da iminente catástrofe ecológica, sua insuficiência e sua autocontradição. Esta se apresenta sob a figura da perda de controle sobre si mesmo em que mergulha o programa baconiano, por sua incapacidade de proteger não somente o homem de si mesmo, mas também de proteger do homem a natureza e a própria natureza humana, tal como esta se revelou em sua essência até aqui. Essa dupla necessidade de proteção surge justamente por meio da extensão desmedida do poder alcançado no percurso do progresso técnico e da compulsão paralelamente crescente a seu emprego, que conduziu à espantosa impotência de pôr termos ao extensivo e previsível progresso destrutivo de si mesmo e de suas obras. (GIACOIA JR, 1999, p. 419). 
Ora, vimos que Francis Bacon defendia o progresso científico para se aproximar de Deus e exercer a caridade, um amor extremado à humanidade e à divindade. Isso significa que, ao restaurar a plena autorização do homem para exercer o domínio sobre a natureza e também sobre si próprio, o projeto baconiano não o faz retirando do ser humano a sua dignidade de criatura privilegiada, pois a própria investigação sobre a natureza se associa à sua função de "ministro e intérprete da natureza" (BACON, 1979, Novum Organum, I, I), isto é, colabora com a providência divina no sentido de construir artes e técnicas humanas para o bem-estar da sociedade. Em outros termos, seu programa propicia claramente subsídios para o desenvolvimento de uma ética científica de cunho social e a implementação de exigências e critérios de apreciação da investigação científica nos âmbitos econômico e político.

Por outro lado, observamos que, ao entrarmos na contemporaneidade, o avanço acachapante da ciência ocorreu em paralelo com o abandono pleno da ética tradicional. As armas químicas e atômicas utilizadas nos conflitos no século $X X$, os inúmeros problemas ecológicos atuais decorrentes da nossa relação com a natureza, por exemplo, são alguns indícios que o sucesso extremado deste "programa" baconiano possa ter gerado desdobramentos cruéis na contemporaneidade. Ora, esse mais recente uso da arte sobre a natureza desafia novas concepções éticas, que antes não precisavam ser discutidas, afinal os próprios fundamentos metafísico-teológicos dos empreendimentos filosóficos modernos, como os de Bacon, forneciam a garantia para uma ética de cunho social. 


\section{Referências}

AUBREY, John (1898). 'Brief Lives', chiefly of contemporaries, set down by John Aubrey, between the years 1669 \& 1696. Rochester: The Boydell Press, 1982.

ALFONSO-GOLDFARB, Ana Maria; BELTRAN, Maria Helena R. (Org.). Escrevendo a história da ciência: tendências, propostas e discussões historiográficas. São Paulo: Educ; Livraria Editora da Física; Fapesp, 2004.

BACON, Francis. Advancement of Learning. In: SPEDDING, James; LESLIE, Robert; HEATH, Douglas D. (orgs). The Works of Francis Bacon. Vol. III. Longman \& Co: London, 1859. Reprint: Stuttgart: Fr. Frommann, 1963a.

. De dignitate et augmentis scientiarum. In: SPEDDING, James; LESLIE, Robert; HEATH, Douglas D. (orgs). The Works of Francis Bacon. Vol. X. Longman \& Co: London, 1859. Reprint: Stuttgart: Fr. Frommann, 1963b.

. Novum Organum, Nova Atlântida. 2. ed. Tradução de José Aloísio Reis de Andrade. São Paulo: Abril cultural, 1979. (Os Pensadores).

CHAUI, Marilena. Breve consideração sobre a utopia e a distopia. In: SILVA JÚNIOR, Ivo (Org.). Filosofia e Cultura: Festschrift em homenagem a Scarlett Marton. 1. ed. São Paulo: Editora Barcarolla, 2011. v. 1, p. 361-386.

GIACOIA JR., Osvaldo. Hans Jonas: Por que a técnica moderna é um objeto para a ética. Natureza Humana, v. 1, n. 2, p. 407-420, 1999. 
HOOKE, Robert (1705). The Posthumous Works of Robert Hooke, M.D.S.R.S. New York: Johnson Reprint, 1969.

MORAES JÚNIOR, Helvio Gomes. O tema da viagem e seus desdobramentos na Nova Atlântida de Francis Bacon. Palimpsesto, v. 1, p. 1-20, 2009.

PELTONEN, Markku. The Cambridge Companion to Bacon. Cambridge: Cambridge University Press, 1996.

ROSSI, Paolo. A ciência e a filosofia dos modernos. São Paulo: UNESP, 1992.

. Os filósofos e as máquinas. São Paulo: Companhia das Letras, 1989.

WESTFALL, Richard. Science and Religion in Seventeenth-Century England. Massachusetts: Yale University Press, 1958.

ZATERKA, Luciana. As teorias da matéria de Francis Bacon e Robert Boyle: forma, textura e atividade. Scientiae Studia, v. 8, n. 3, p. 587-602, 2013. 


\title{
A NOVA FACE DO MUNDO CELESTE NAS IMAGENS DA LUNETA DE GALILEU ${ }^{1}$
}

\author{
Paulo Tadeu da Silva \\ Paluana Curvelo Luquiari
}

\section{Introdução}

[...] foram necessários ao homem séculos de trabaIho e de coragem intelectual para passar da definição de natureza por naturalmente e de naturalmente por natureza, isto é, da impressão de uma necessidade contra a qual somos impotentes, para a afirmação audaciosa de que a natureza forma um conjunto, de que as próprias coisas se encontram submetidas a uma lei. [...] bastar-nos-á conhecer estas leis para nos situarmos a nós mesmos no nosso lugar neste conjunto, para entrar nele e não nos deixarmos mais dominar por ele - e isso será uma primeira conquista. Depois, dir-se-á um dia: se conhecermos as leis, podemos, pois, servir-nos das coisas e tornar-nos "donos e

\footnotetext{
1 Agradecemos aos membros de nosso grupo de estudos e pesquisa - Caterine, Eduardo, Natan e Victor - pela leitura e pelas sugestões apresentadas, as quais contribuíram significativamente para a clareza do texto e a correção de alguns equívocos.
} 
senhores" da natureza, e isso será uma segunda fase. (LENOBLE, 1969, p. 184-185).

Essa passagem nos coloca diante de um duplo aspecto da filosofia natural desenvolvida ao longo do século XVII. De um lado, é por intermédio dela que se chega à concepção de que os eventos naturais são regidos por leis naturais, cujo conhecimento permite escapar do domínio da natureza sobre o homem; por outro, é precisamente esse conhecimento que fará a inversão entre homem e natureza, isto é, aquilo que permitirá que o homem domine a natureza por meio da ciência e da técnica. Esse duplo aspecto se faz notar em diversos autores do período, dentre os quais Descartes e Galileu são os dois maiores exemplos. Em contraposição a uma concepção teleológica da natureza, em cujo seio coisas e fenômenos também devem ser explicados pelas causas finais, os filósofos modernos priorizaram explicações de cunho mecanicista, nas quais apenas as causas materiais e eficientes serão requisitadas. Um dos motivos para essa mudança de pensamento é que a concepção teleológica da natureza atribuía um animismo aos corpos, bem como sustentava uma visão mágica do mundo; ideia que os autores modernos procuraram contestar (VIDEIRA, 2009, p. 43).

O segundo aspecto, relacionado com o papel da ciência e da técnica no conhecimento do mundo natural, indica uma mudança radical e, em grande medida, relacionada com o modo como os fenômenos naturais serão explicados: a natureza passa a ser encarada de maneira geométrica e matematizada. Esse pensamento é expresso em uma das mais famosas passagens de Galileu, cuja motivação não deve ser desprezada. Se a natureza está expressa em caracteres matemáticos, é porque o conhecimento científico não deve estar subordinado à opinião de quem quer que seja, mas apenas aos cânones que orientam a razão: 
Parece-me também perceber em Sarsi sólida crença que, para filosofar, seja necessário apoiar-se nas opiniões de algum célebre autor, de tal forma que o nosso raciocínio, quando não concordasse com as demonstrações de outro, tivesse que permanecer estéril e infecundo. Talvez considere a filosofia como um livro e fantasia de um homem, como a llíada e Orlando Furioso, livros em que a coisa menos importante é a verdade daquilo que apresentam escrito. Sr. Sarsi, a coisa não é assim. A filosofia encontra-se escrita neste grande livro que continuamente se abre perante nossos olhos (isto é, o universo), que não se pode compreender antes de entender a língua e conhecer os caracteres com os quais está escrito. Ele está escrito em língua matemática, os caracteres são triângulos, circunferências e outras figuras geométricas, sem cujos meios é impossível entender humanamente as palavras; sem ele vagamos perdidos dentro de um obscuro labirinto. (GALILEI, 1973, p. 119).

Desse modo, a fim de compreender a natureza, a ciência deve lançar mão da geometria e da matemática. Sem tais instrumentos, como afirma Galileu, "vagamos perdidos dentro de um escuro labirinto". Se o conhecimento da natureza exige, tal como sustentado por Galileu, o apoio da matemática e da geometria, o desenvolvimento da ciência moderna nos mostra que esse conhecimento também deve ser amparado pela técnica. Com efeito, é por meio dela que os filósofos naturais foram capazes de ampliar a sua capacidade de observação e experimentação, cujo resultado se faz notar tanto na sofisticação das teorias científicas quanto no domínio da natureza pelo homem, aspecto destacado por Lenoble (1969) no trecho anteriormente referido. Assim, a articulação entre a técnica e a matemática estabelece o terreno no qual a ciência moderna colherá seus frutos, com importantes consequências para a observação 
astronômica e a descoberta de uma nova face dos céus. É precisamente nesse último contexto que encontraremos algumas contribuições de Galileu, cujas observações astronômicas têm um impacto relevante no âmbito da cosmologia.

\section{Técnica e ciência: a construção da luneta}

Na Antiguidade e na Idade Média, a elaboração de aparatos técnicos era feita principalmente por artesãos e não por cientistas ou, como chamados na época, filósofos naturais. Quando um deles precisava, por exemplo, de uma lente polida, deveria recorrer a um artesão. No período moderno, essa situação se alterou e os próprios filósofos naturais passaram a desenvolver os instrumentos que necessitavam para o estudo e a investigação dos fenômenos naturais. O desenvolvimento de instrumentos científicos passa a ter uma importância central na filosofia natural do período e, nesse contexto, o nome de Galileu merece, novamente, ser citado.

O filósofo teve notícias de um instrumento que aproximava os objetos, denominado luneta ${ }^{2}$. Tal instrumento, originário da

2 Como apresentado por Leitão (2010, p. 39), no estudo introdutório à tradução portuguesa do Sidereus nuncius, temos, ao menos, três relatos distintos de Galileu sobre como tivera notícias de tal instrumento, a saber: o que informa no Sidereus nuncius, em 1610; o que encontramos em uma carta de 29 de agosto de 1609 a Benedetto Landucci (EN, X, p. 253); e, em 1623, o que está presente em $O$ ensaiador (EN, VI, p. 258). Porém, os historiadores admitem que Galileu tomou o conhecimento da luneta em 1609 por intermédio de seu amigo Paolo Sarpi. Não há consenso sobre quem haveria inventado, de fato, a luneta. Há indícios do uso de tubos ópticos (sem lentes) para o estudo da astronomia desde a Idade Média, e da invenção das primeiras lunetas (tubos ópticos com duas lentes) desde o século XVI, por exemplo: Leonardo da Vinci (por volta de 1508), Thomas Digges e William Bourne (no final do século XVI), Girolamo Fracastoro (invento anunciado em seu livro Homocentrica, de 1538), 
Holanda, tinha uma capacidade de aproximação de cerca de três vezes. Não obstante alguns esforços, Galileu não conseguiu ter em mãos o instrumento holandês e, a partir de algumas descrições, decidiu construir sua própria luneta. Por meio de tentativa e erro - já que não era plenamente versado nas técnicas ópticas -, Galileu conseguiu reproduzi-la cerca de três meses depois que ouviu falar dela.

Ora, mas se a luneta já existia, por que associamos tão fortemente a imagem de Galileu com a do instrumento? Fazemos tal associação porque o filósofo italiano não se contentou apenas em reproduzir a luneta, mas buscou aprimorá-la e conferir-lhe uma finalidade científica. Além disso, o italiano teve a ideia de colocar a luneta em uma base, para oferecer-lhe maior sustentação e realizar observações mais precisas (VIDEIRA, 2009, p. 50). Galileu construiu um instrumento capaz de produzir uma aproximação de cerca de nove vezes, o qual chamou de perspicillum; depois um instrumento que aproximava 20 vezes e chegou à produção de uma luneta que aproximava os objetos em 30 vezes - a qual não utilizou em suas observações astronômicas, por não produzirem imagens muito nítidas, além de limitar o campo de visão, de uma maneira não desejável ao autor (LEITÃO, 2010, p. 44). A despeito do trabalho técnico relacionado com o aprimoramento da luneta, precisamos reconhecer que a maior contribuição de Galileu, isto é, aquela que provocou impactos sem precedentes, diz respeito às suas observações astronômicas.

Antes de analisarmos as observações de Galileu, publicadas pelo autor em um pequeno texto, intitulado Sidereus nuncius (1610), cabe ressaltar que tais observações não foram

Giovanni Baptista Della Porta (em seu livro Magiae naturalis sive de miraculis rerum, de 1558) (LEITÃO, 2010, p. 32-34). 
aceitas de imediato por toda a comunidade científica da época. Isso porque os contemporâneos de Galileu estavam apegados a uma tese filosófica tradicional que questionava o conhecimento obtido através da visão, por considerá-lo incerto e duvidoso. De acordo com essa tese, esse tipo de conhecimento deveria ter alguma comprovação, muitas vezes provinda do tato, para ser tomado como verdadeiro (VIDEIRA, 2009, p. 51-52). Assim, quando Galileu divulgou os resultados de suas observações com seu perspicillum no Sidereus nuncius, a desconfiança quanto à veracidade dos dados visuais obtidos por intermédio desse instrumento foi imediata. Tal desconfiança estava, sem dúvida, relacionada tanto às eventuais ilusões de óptica produzidas pelas lentes quanto, e principalmente, ao fato de que havia um evidente conflito entre as observações de Galileu e as teses cosmológicas admitidas pela tradição filosófica e científica.

Drake (2001, p. 51) sublinha que: "[...] a maioria dos filósofos e astrônomos declararam [as descobertas de Galileu] ilusões de óptica e ridicularizaram Galileu ou o acusaram de fraude". À dificuldade imposta por essa tese filosófica tradicional somaram-se outras, como o fato de ninguém saber explicar perfeitamente o funcionamento da luneta, além do fato de as observações feitas a olho nu apresentarem algumas discrepâncias em comparação com aquelas feitas com o uso do aparato. Diante dessas complicações, Galileu sentiu necessidade de apresentar argumentos teóricos que se somassem às evidências observacionais do Sidereus nuncius. Assim, o autor desenvolveu alguns argumentos físicos que ajudavam a comprovar as observações que havia publicado no Sidereus nuncius, notadamente no que se refere às observações da Lua, bem como argumentos racionais, que visavam a instruir aqueles que fizessem observações com a luneta a interpretá-las corretamente. Tais 
argumentos físicos são encontrados em seu Diálogo sobre os dois máximos sistemas do mundo ptolomaico e copernicano, de 1632 (GALILEI, 2011).

Porém, mesmo diante de todas essas dificuldades, nem todos os contemporâneos de Galileu o acusaram de fraude. Com efeito, uma parte dos filósofos naturais e astrônomos considerava as observações de Galileu não somente verdadeiras, mas fundamentais para que se pudesse colocar em xeque o sistema aristotélico-ptolomaico. Dentre eles, Kepler é um nome que merece destaque. $\mathrm{O}$ astrônomo alemão estava fortemente convencido de que o modelo ptolomaico não representava verdadeiramente o mundo celeste e que, portanto, era preciso constituir um novo sistema astronômico a partir das teses sustentadas por Copérnico em meados do século XVI. Se a habilidade matemática de Kepler permitia-Ihe elaborar, do ponto de vista teórico, um novo sistema astronômico, os dados observacionais de seus contemporâneos - dentre os quais aqueles obtidos por Brahe, foram-lhe os mais caros - representavam o apoio empírico necessário e fundamental para suas conjecturas teóricas.

\section{A nova imagem do céu: as observações astronômicas de Galileu}

A visão hegemônica de mundo no começo do século XVII era aquela proposta pelo sistema aristotélico-ptolomaico. Em resumo, nesse sistema o Cosmo era composto por um conjunto de esferas cristalinas e sólidas que orbitavam a Terra e nas quais os planetas estariam presos. A última esfera era a das estrelas fixas, que limitava esse sistema, do qual a Terra era o centro. 
Havia uma divisão desse Cosmo em duas grandes regiões, a saber, a sublunar e a supralunar. A primeira delas, que se refere à parte do mundo que fica abaixo da Lua, seria composta por quatro elementos, terra, água, ar e fogo. Por ser imperfeita, a região sublunar era caracterizada pela geração e corrupção dos corpos e pela busca de seus respectivos lugares naturais: os corpos graves, constituídos de terra e de água, tenderiam para o centro do Cosmo e os corpos leves, constituídos de ar e de fogo, tenderiam a se afastar do mesmo. A região supralunar, por sua vez, incluía a Lua e tudo o que está acima dela. Tudo nesta região reflete sua perfeição: ela é inteiramente constituída do elemento éter. Não há mudança, geração ou corrupção, pois tudo já se encontra em sua mais perfeita forma, e o único movimento natural existente é o circular, pois apenas esse movimento poderia ser perpétuo e imutável ${ }^{3}$.

Ao dirigir a sua luneta para os céus e observar aquilo que jamais fora visto, Galileu contribui para a derrocada desse cenário tradicional. Portanto, não é surpreendente que o autor comece o Sidereus nuncius afirmando que as coisas que ele propõe são grandiosas, tanto pela excelência do assunto quanto pela sua novidade inaudita e, ainda, pelo instrumento que o auxiliou a tornar essas novidades manifestas (GALILEI, 2010, p. 151). Tais novidades compõem três conjuntos distintos de observações. $\mathrm{O}$ primeiro deles diz respeito à natureza da Lua. Como veremos, as observações de Galileu indicam que a Lua possui um relevo semelhante ao da Terra, além de ser igualmente iluminada por esta última. O segundo conjunto de observações está

3 O movimento circular das esferas celestes é tradicionalmente nomeado como axioma platônico. De acordo com ele, todos os planetas movimentam-se em trajetórias circulares e com velocidade uniforme. Esse axioma dominou toda a tradição cosmológica até Kepler, que o abandona ao estabelecer que os planetas se movem segundo trajetórias elípticas e com velocidade variável. 
relacionado com as nebulosas e a Via Láctea: Galileu conclui que elas são compostas por uma infinidade de estrelas, com enormes distâncias entre si e, portanto, não se poderia mais afirmar a existência de uma esfera das estrelas fixas. Finalmente, o terceiro conjunto de observações refere-se aos satélites de Júpiter, que jamais foram vistos pelos astrônomos.

Galileu não foi o primeiro a fazer observações da Lua com a luneta. Thomas Harriot já fizera e publicara suas conclusões da observação da Lua, bem como um desenho da mesma, quase seis meses antes da publicação do Sidereus nuncius ${ }^{4}$. O italiano, porém, principalmente por conta de sua habilidade artística, foi além do inglês. Como sustenta Panofsky (KOYRÉ, 2011, p. 289), em seu estudo Galileu como crítico das artes: atitude estética e pensamento científico ${ }^{5}$, Galileu era um excelente desenhista, apreciava e compreendia todas as artes subordinadas ao desenho, entre elas, a perspectiva e a relação entre luz e sombra. Quando observou a Lua, além de possuir uma luneta mais potente que aquelas de Harriot, Galileu também foi capaz de produzir um desenho muito mais preciso da superfície da Lua - de fato, se compararmos o desenho do filósofo seiscentista com fotos atuais tiradas por satélites, perceberemos a precisão de seus desenhos. Por ser versado em tais artes, Galileu, ao analisar as manchas mais claras e mais escuras, maiores e menores, presentes na imagem da superfície da Lua vista pela luneta, compara-as com as sombras dos vales e montanhas terrestres e conclui que:

\footnotetext{
4 Harriot - conforme salientam Leitão (2010, p. 56), em nota de rodapé no 65, e Biagioli (2007, p. 78), em nota de rodapé $n$ ㅇ 2 - foi o primeiro a fazer e registrar observações lunares com uma luneta, uma vez que seu primeiro desenho da superfície lunar data de 26 de junho de 1609, quase oito meses antes da publicação do Sidereus nuncius.

${ }^{5}$ Artigo publicado, em março de 1956, em Isis, intitulado Galileo as a critic of the arts: aesthetic attitude and scientific thougth (PANOFSKY, 1956).
} 
[...] a Lua não é de maneira nenhuma revestida de uma superfície lisa e perfeitamente polida, mas sim de uma superfície acidentada e desigual, e que, como a própria face da Terra, está coberta em todas as partes por enormes protuberâncias, depressões profundas, e sinuosidades. (GALILEI, 2010, p. 152).

Portanto, Galileu percebe que a Lua, tal como a Terra, não é perfeita, uma vez que ela possui uma superfície acidentada e desigual. A Lua, diz Galileu, é constituída por cavidades e protuberâncias e é marcada por cadeias de montanhas e profundezas de vales. A implicação de uma afirmação como essa era bastante séria, pois tal fenômeno não seria possível na região supralunar de Aristóteles, uma vez que, para este, a Lua deveria ser lisa e polida. Porém, mais do que apenas afastar a Lua de sua suposta perfeição, Galileu aproximou-a da Terra, retomando a antiga opinião pitagórica ao afirmar que a Lua seria outra Terra, com sua parte mais brilhante representando as superfícies terrosas e sua parte mais obscura, as superfícies aquosas (GALILEI, 2010, p. 159). Seu maior argumento para comprovar tal afirmação é a existência da luz secundária, que indica que também a Terra possui características que acreditávamos existir apenas na Lua: Galileu diz que há, na Lua, uma luz que não viria do Sol, nem de qualquer outra estrela, nem mesmo da própria Lua. Assim, essa luz secundária não poderia ter outra causa que não a Terra. Em suas palavras:

Uma vez, pois, que esta luz secundária não é intrínseca e própria à Lua, e também não é emprestada por nenhuma estrela nem pelo Sol, e visto que na vastidão do mundo não resta nenhum outro corpo a não ser a Terra, pergunto então o que devemos pensar? [...] a Terra, numa troca igual e agradecida, retribui à 
Lua uma luz igual àquela que recebe da Lua durante quase todo o tempo na mais profunda escuridão da noite. (GALILEI, 2010, p. 171).

As observações da Lua por Galileu contribuíram para o questionamento da divisão entre mundo sublunar e supralunar, uma vez que a Lua apresentava, segundo as imagens obtidas pelo telescópio, características semelhantes às da Terra. Outros argumentos, oriundos das demais observações descritas no Sidereus nuncius, somam-se àquilo que é dito sobre a Lua para provar que outros aspectos descritos pelo cosmo aristotélico também estavam equivocados ${ }^{6}$.

Nesse sentido, as observações das nebulosas e da Via Láctea fortalecem a desconfiança de que aquela divisão do mundo em duas regiões não era correta. Como anteriormente citado, o número e a distância entre as estrelas é muito maior do que se acreditava até aquele momento, conforme Galileu apresenta nos seus desenhos das constelações de Órion e das Plêiades. Contudo, de modo análogo aos problemas oriundos da observação da Lua por intermédio da luneta, Galileu justifica inicialmente a maneira como tais astros são vistos a olho nu e com o auxílio daquele instrumento. Ele afirma que a imagem das estrelas e dos planetas não é significativamente aumentada com o uso da luneta, tal como ocorre com objetos mais próximos, inclusive a Lua. Segundo Galileu, a razão de tal fenômeno é a existência de certa "cabeleira de raios brilhantes" tanto nas estrelas fixas como nos planetas, quando observados com a olho nu. Desse modo, sem o auxílio da luneta, não enxergamos esses corpos em seu tamanho simples, mas sempre com a dita

\footnotetext{
${ }^{6}$ Um estudo sobre as consequências dessas observações pode ser encontrado em: Luquiari e Silva (2014).
} 
cabeleira ao seu redor. A presença dessa cabeleira faria com que as estrelas não fossem aumentadas tantas vezes quanto os outros objetos, se compararmos a imagem vista a olho nu com aquela obtida por intermédio da luneta ${ }^{7}$. Além da percepção de que o número de estrelas era muito maior do que se imaginava anteriormente, Galileu afirma que as estrelas que eram chamadas nebulosas são, na verdade, um aglomerado de estrelas muito pequenas ou muito distantes, impossíveis de se diferenciar a olho nu.

O problema do brilho das estrelas ainda foi discutido por Galileu em vários de seus livros até o fim de sua vida, como na terceira Carta sobre as manchas solares (1613), no Discurso dos cometas (1619), em O ensaiador (1623), no Diálogo sobre os dois máximos sistemas do mundo (1632) e em As operações astronômicas, livro que Galileu escreveu no fim de sua vida e deixou incompleto (LEITÃO, 2010, p. 70-71). Porém, a observação com mais implicações e, por esse motivo, a mais contestada, foi a existência de "[...] quatro planetas nunca vistos desde o princípio do mundo até nossos dias" (GALILEI, 2010, p. 179) orbitando Júpiter. De fato, Galileu considerou a observação dessas estrelas como a mais importante observação astronômica relatada no Sidereus nuncius.

A primeira observação de tais estrelas se deu no dia 7 de janeiro de 1610, quando Júpiter se mostrou e Galileu o observou

\footnotetext{
7 A razão disso, segundo Leitão (2010, p. 69), não é a cabeleira cuja existência foi suposta por Galileu, mas sim a difração que ocorre quando a luz passa por uma pequena abertura, como a objetiva da luneta ou a pupila do olho. Tal fato torna impossível que se obtenha imagens nítidas de objetos muito pequenos, como as estrelas, quando vistas à enorme distância que nos encontramos delas. Leitão acrescenta, em nota (número 87), que: “[...] seja qual for o seu tamanho real e a ampliação da luneta, o que se vê são apenas os seus discos de difração" (p. 69).
} 
com a luneta ${ }^{8}$. Ao fazê-lo, o filósofo percebeu que havia três pequenas estrelas perto do planeta. Ainda que ele acreditasse, inicialmente, que elas pudessem ser estrelas fixas, tal fenômeno o intrigou, pois formavam uma linha reta paralela à eclíptica e eram mais brilhantes do que outras estrelas de mesma grandeza. No dia seguinte, quando Galileu tornou a fazer observações do planeta, notou que essas três estrelas se encontravam em um arranjo totalmente diferente do anterior. Por um momento chegou a desconfiar que seu livro de cálculo astronômico estivesse equivocado a respeito do movimento de Júpiter, mas decidiu continuar suas observações diariamente para chegar a uma conclusão a respeito da mudança de posição dessas estrelas. A partir de então, ele passa a observar Júpiter sistematicamente, procedimento minuciosamente descrito em seu livro de 1610.

No dia 9 de janeiro, não conseguiu fazer as observações, pois o céu estava nublado. No dia seguinte, porém, encontrou uma nova configuração: apenas duas estrelas perto de Júpiter, sendo que a terceira havia desaparecido, muito provavelmente porque estava oculta pelo planeta. No dia 11, apesar de as duas estrelas manterem suas posições, a mais oriental parecia maior do que a outra, sendo que no dia anterior elas apresentavam a mesma grandeza. Com essas observações, Galileu concluiu “[...] que existiam no céu três estrelas errantes em torno de Júpiter, como Vênus e Mercúrio em torno do Sol" (GALILEI, 2010, p. 181).

\footnotetext{
8 Leitão (2010, p. 78) menciona - em nota de rodapé no 101 - que, em janeiro de 1610, Júpiter apresentava condições favoráveis para sua observação, pois tinha passado a oposição, quando estava com sua menor distância em relação à Terra. Além disso, Galileu preferia sempre fazer suas observações durante o começo da noite, e, nesta época, apenas Júpiter e Saturno eram visíveis. Uma vez que Saturno estava muito baixo, ou seja, apenas poucos graus afastado do horizonte, Júpiter era o astro mais brilhante da noite, o que favoreceu a observação de Galileu.
} 
No dia 12, a terceira estrela tornou a surgir; mas, no dia 13, pela primeira vez, Galileu avistou quatro pequenas estrelas próximas a Júpiter, formando a mesma linha quase reta - quase, pois a estrela do meio estava um pouco desviada para o norte. As observações dessas estrelas, que só eram interrompidas quando o céu estava nublado, continuaram diariamente até o dia 2 de março de 1610. Durante todo esse período, Galileu tomou nota e desenhou todas as posições das estrelas e de Júpiter, constituindo um longo protocolo de observação.

O autor dedicou sua descoberta a Cosme II, nomeando os satélites que orbitam Júpiter de planetas Mediceus ou de estrelas Mediceias ${ }^{9}$. Apesar de não tratar abertamente do copernicanismo no Sidereus nuncius, a descoberta dessas estrelas foi fundamental para que Galileu se convertesse definitivamente ao novo sistema astronômico, admitindo abertamente sua posição favorável às doutrinas de Copérnico, pela primeira vez, nas Cartas sobre as manchas solares (1613), onde relatou sua observação da existência de manchas no Sol (DRAKE, 2001).

A observação das estrelas Mediceias foi crucial para o copernicanismo, pois comprovava para a comunidade científica da época que era possível que estrelas errantes orbitassem outros planetas, ou seja, que existiam órbitas que não se davam ao redor da Terra. Portanto, ela não poderia ser tomada como o centro dos movimentos de todos os orbes celestes, tal como afirmara Copérnico na primeira descrição de seu sistema heliocêntrico, presente no Commentariolus. Nesse pequeno texto, redigido por volta de 1510, o astrônomo polonês afirma:

9 Galileu fez tal homenagem, pois, percebendo a importância de suas observações, viu que poderia aproveitar-se delas para se aproximar da corte dos Médici. 
"O centro da Terra não é o centro do mundo, mas apenas o da gravidade e do orbe lunar" (COPÉRNICO, 1990, p. 14).

Como afirma Kuhn (2002), a descoberta dos satélites de Júpiter colocava um novo problema a ser investigado e explicado pelos astrônomos do período, a saber: por que determinados corpos celestes orbitavam ao redor de um planeta e não em torno do centro do mundo?

Havia, segundo parecia, novos mundos "nos Planetas" assim como no "Firmamento". Mais importante, estes novos mundos não podiam ser concebidos, nem na hipótese de Ptolomeu nem na de Copérnico, a moverem-se em órbitas quase circulares à volta do centro do universo. Aparentemente, moviam-se à volta de um planeta, e o seu comportamento era, portanto, o mesmo que o da Lua da Terra na astronomia de Copérnico. A velha astronomia, tal como a nova, teria de admitir a existência de satélites, governados pelos planetas. Além disso, e talvez a maior consequência, as observações de Júpiter forneceram um modelo visível do próprio sistema solar de Copérnico. Aqui, no espaço planetário, havia um corpo celeste rodeado pelos seus próprios "planetas", tal como os planetas previamente conhecidos circulavam à volta do Sol. Os argumentos em favor do copernicanismo foram multiplicados pelo telescópio quase tão rapidamente como os próprios corpos celestes. (KUHN, 2002 , p. 237).

O Sidereus nuncius se tornou, portanto, um livro importante para fortalecer os argumentos contra a cosmologia aristotélico-ptolomaica, bem como para defender a cosmologia copernicana, pois as evidências observacionais obtidas por Galileu não poderiam ser explicadas pelo antigo modelo e, por outro lado, fortaleciam as razões em prol do segundo. 
Assim, com o Sidereus nuncius, Galileu inicia o longo combate que realizará, de modo definitivo, a transição entre o antigo modelo cosmológico e o novo, tornando obsoleto o cosmo antigo e medieval compreendido como um todo limitado e hierarquicamente ordenado, constituído por duas regiões heterogêneas compostas de corpos de natureza diferentes e submetidos a leis diferentes. (MARICONDA; VASCONCELOS, 2006, p. 59).

Essas observações também abriram o caminho para que Galileu percebesse, ao defender o copernicanismo, a necessidade de uma física que embasasse esse novo modelo cosmológico, o que propôs no livro que provocou sua condenação pela Igreja, o já citado Diálogo sobre os dois máximos sistemas do mundo ptolomaico e copernicano (GALILEI, 2011).

\section{Considerações finais}

Essa breve exposição sobre as descobertas astronômicas de Galileu nos coloca diante de alguns aspectos centrais da ciência moderna, tendo em vista a íntima relação entre história e filosofia da ciência. O primeiro aspecto diz respeito à elaboração e ao aprimoramento de aparatos técnicos que ampliem a nossa capacidade de observação. Nesse contexto, a invenção e a utilização da luneta é, sem qualquer dúvida, um evento da maior importância. Seja porque ela permitiu a descoberta de novos astros celestes ou a investigação mais precisa daqueles que já eram conhecidos, seja porque sua invenção demandou dos filósofos naturais da modernidade o aprimoramento da técnica de polimento de lentes e a construção de lunetas mais 
poderosas ${ }^{10}$. Desse modo, a utilização desse instrumento científico foi responsável pelas profundas e inevitáveis mudanças no âmbito da astronomia e da cosmologia, determinando o abandono do modelo tradicional e, com ele, a adoção de um novo paradigma.

Esse é o tipo de mudança que uma parte dos historiadores e filósofos da ciência denominam de revolução científica, dentre os quais Kuhn é uma referência obrigatória. Em seu livro A estrutura das revoluções científicas, o autor dedica-se a examinar de que modo as revoluções ocorrem, bem como os diversos fatores que as determinam (KUHN, 1991). Não nos parece fora de lugar afirmar que as observações presentes no Sidereus nuncius são um exemplo de descoberta científica que, por vezes, está na raiz de uma mudança de paradigma. Os fatos descritos por Galileu podem ser tomados como as anomalias que não poderiam ser explicadas pelo modelo proposto por Aristóteles e Ptolomeu e que, portanto, contribuíram decisivamente para a revolução científica levada a cabo por todos aqueles que defenderam as hipóteses aventadas por Copérnico. Se levarmos em consideração o esquema teórico proposto por Kuhn, podemos afirmar que as observações astronômicas de Galileu promoveram a consciência de uma anomalia que mudaria a imagem que se tinha do mundo: abandona-se a visão de um Cosmo limitado em prol da concepção de um Universo infinito. Nesse sentido, o cenário proposto no Sidereus nuncius, ao que tudo indica, adapta-se àquilo que Kuhn (1991, p. 78) afirma na seguinte passagem:

10 Um exemplo disso pode ser encontrado em Descartes, em um dos ensaios que acompanham o Discurso do método (1637), a saber: A dióptrica (AT, 6; BEYSSADE; KAMBOUCHNER, 2009). Os dois últimos discursos desse ensaio são dedicados, respectivamente, à luneta e à maneira de se talhar vidros (técnica diretamente relacionada com a boa construção de lentes). 
A descoberta começa com a consciência da anomalia, isto é, com o reconhecimento de que, de alguma maneira, a natureza violou as expectativas paradigmáticas que governam a ciência normal. Segue-se então uma exploração mais ou menos ampla da área onde ocorreu a anomalia. Esse trabalho somente se encerra quando a teoria do paradigma for ajustada, de tal forma que o anômalo se tenha convertido em esperado.

Contudo, no caso em questão, esse ajuste não foi possível. O declínio da astronomia Ptolomaica foi inevitável, tanto quanto o abandono da cosmologia de inspiração aristotélica. Assim, houve a necessidade de uma mudança do paradigma vigente a fim de explicar as anomalias percebidas por Galileu. Tal necessidade, bem como a primeira impressão dessas anomalias como fraudes inventadas pelo italiano, é constatada no que se segue da passagem supramencionada de Kuhn (1991, p. 78): “[...] até que o cientista tenha aprendido a ver a natureza de um modo diferente o novo fato não será considerado completamente científico". Portanto, em um primeiro momento, as observações de Galileu foram encaradas como aberrações e ilusões, ou seja, de modo não científico. No entanto, as lentes da luneta de Galileu desenharam uma nova face dos céus; assim, definiram uma nova visão de natureza que, consequentemente, carecia de uma nova teoria que a explicasse. Em outras palavras: um novo paradigma científico.

\section{Referências}

ADAM, Charles; TANNERY, Paul (Ed.). CEuvres de Descartes. Paris: Vrin; Centre National du Livre, 2000. 11 v. (AT) 
BEYSSADE, Jean-Marie; KAMBOUCHNER, Denis (Ed.). René Descartes. CEuvres completes - Vol. III: Discours de la Méthode et Essais. Paris: Tel-Gallimard, 2009.

BIAGIOLI, Mario. Galileo's instruments of credit. Chicago: The University of Chicago Press, 2007.

COPÉRNICO, Nicolau. Commentariolus: pequeno comentário de Nicolau Copérnico sobre suas próprias hipóteses acerca dos movimentos celestes. Tradução, introdução e notas de Roberto de Andrade Martins. São Paulo: Nova Stella; Rio de Janeiro: Coppe-MAST, 1990.

DRAKE, Stillman. Galileo: A Very Short Introduction. Oxford: Oxford University Press, 2001.

FAVARO, Antonio (1895). Le opere di Galileo Galilei: edizione nazionale sotto gli auspicii di sua maestà il ré D'italia. Tipografia Di G. Barbéra: Firenze, 1923-1933, v. 20.

GALILEI, Galileu. O ensaiador. 1. ed. São Paulo: Abril Cultural, 1973. (Os Pensadores, vol. XII).

. Sidereus nuncius: o mensageiro das estrelas. Tradução, estudo e notas de Henrique Leitão. 3. ed. Lisboa: Fundação Calouste Gulbenkian, 2010.

- Diálogo sobre os dois máximos sistemas do mundo ptolomaico e copernicano. Tradução, introdução e notas de Pablo Rubén Mariconda. 3. ed. São Paulo: Associação Filosófica Scientiae Studia; Editora 34, 2011.

KOYRÉ, Alexandre. Estudos de história do pensamento científico. Tradução de Márcio Ramalho. 3. ed. Rio de Janeiro: Forense Universitária, 2011. 
KUHN, Thomas S. A estrutura das revoluções científicas. Tradução de Beatriz Vianna Boeira e Nelson Boeira. São Paulo: Editora Perspectiva S. A., 1991.

- A revolução copernicana. Tradução de Marília Costa Fontes. Lisboa: Edições 70, 2002.

LEITÃO, Henrique. Estudo introdutório. In: GALILEI, Galileu. Sidereus nuncius: o mensageiro das estrelas. 3. ed. Lisboa: Fundação Calouste Gulbenkian, 2010. p. 17-136.

LENOBLE, Robert. História da ideia de natureza. Tradução de Teresa Louro Pérez. Lisboa: Edições 70, 1969.

LUQUIARI, Paluana Curvelo; SILVA, Paulo Tadeu da. A dissolução de uma dicotomia aristotélica: alguns argumentos de Galileu em defesa da semelhança entre a Lua e a Terra. Cognitio-Estudos: revista eletrônica de filosofia, v. 11, n. 2, p. 228-38, 2014.

MARICONDA, Pablo Rubén; VASCONCELOS, Júlio. Galileu e a nova física. São Paulo: Odysseus Editora, 2006.

PANOFSKY, Erwin. Galileo as a critic of the arts: aesthetic attitude and scientific thougth. Isis, v. 47, n. 1, p. 3-15, mar. 1956.

VIDEIRA, Antonio Augusto Passos. As descobertas astronômicas de Galileu Galilei. Rio de Janeiro: Vieira \& Lent, 2009. 


\section{CIÊNCIA FEMINISTA, HISTÓRIA E EPISTEMOLOGIA}

Clara Guimarães Graciela de Souza Oliver

\section{Mulher e ciência}

Desde os primórdios do fazer científico o discurso era feito, basicamente, por homens. Os articuladores da ciência, tal como a conhecemos hoje, possuíam um discurso voltado para os pares masculinos. Como exemplo, podemos citar os trabalhos de Francis Bacon e Renée Descartes (HARDING, 1996; JAPIASSÚ, 2001). Nesse sentido, uma epistemologia feminista foi surgindo a partir de discussões sobre a participação das mulheres na ciência e na sociedade. Esses estudos acabaram questionando o estatuto de saber "solidificado" da ciência moderna.

Segundo Joana Maria Pedro e Miriam Grossi (1998), os estudos feministas buscam salientar o que a epistemologia tradicional tem ignorado: as relações de gênero como fator constituinte da ciência. Esses estudos também teriam admitido que a construção da identidade feminina é cultural e que se relaciona com a história das mulheres. A forma de pensar feminista trouxe 
à baila a subjetividade, contrariando a trajetória tradicional de organização do conhecimento utilizada pelas ciências humanas, advinda das ciências naturais. Sendo assim, o feminismo proporia novas relações entre teoria e prática, um cientista não mais isento, mas que constrói seu conhecimento por meio da interação com indivíduos.

Para Cecília Maria Bacellar Sardenberg e Ana Alice Alcântara Costa (2002, p. 12),

A perspectiva de gênero tem possibilitado a construção de uma epistemologia crítica feminista, um discurso feminista sobre a ciência e uma teoria crítica do conhecimento que, se por um lado fundamenta as bases de um saber feminista, por outro, vem abrindo espaço para questionamentos e reavaliações até mesmo dos próprios fundamentos desse saber.

Nessa perspectiva, a crítica feminista da ciência observa a discriminação das mulheres na estrutura social da ciência e o androcentrismo das ciências. Assim, uma de suas principais críticas está no objetivo totalizante do discurso científico, pois, apesar de se propor como neutra, a ciência não é neutra perante as questões de classe, de raça e de gênero. O resultado seria uma "ciência malconduzida", "distorcida pela visão masculina" (HARDING, 1993, p. 69). Uma ciência que até produz conhecimento sobre as mulheres, mas que não as leva em consideração como sujeitos ativos nas práticas científicas. Dessa forma, os estudos feministas passaram a propor uma nova perspectiva para o contexto científico, problematizando a invisibilidade das mulheres.

Nesse campo, podemos citar os estudos de história das ciências e gênero, que trouxeram à baila o fazer científico praticado por mulheres ao longo da história das ciências no Brasil. 
Muitas dessas mulheres realizaram importantes feitos não só no campo científico, mas também atuando diretamente na esfera política e social, contribuindo para o constante processo de emancipação feminina.

\section{História das ciências e os Estudos de gênero}

Os estudos feministas transitam por várias áreas do saber científico e, para isso, fazem uso da crítica feminista das ciências, apresentando novos modelos e propostas para pensar a ciência. Entretanto, os estudos mais específicos que relacionam história das ciências e gênero foram negligenciados, pois pouco se perguntou sobre essas mulheres que desbravaram as ciências ou mesmo como se deu a divulgação científica para o público feminino (LOPES, 2006b; LOPES; SOUZA, 2007; COSTA, 2006).

Um dos problemas dos historiadores das ciências é que não olham para a sociedade de forma geral, como apontam Lynn Nyhart e Thomas Broman (2002), dispensando as interações sociais. Neste sentido, a temática histórica, que vincula ciências e gênero, pode então contribuir para um novo olhar sobre as relações sociais, em que se compreenda o lugar que se destina ao público e ao privado num dado contexto.

Sendo assim, Maria Margaret Lopes (1998) e Lopes, Souza e Sombrio (2004) afirmam que Evelyn Fox-Keller ${ }^{1}$, em 1978, foi a primeira a relacionar e usar os termos gênero e ciências em conjunto. Isso demonstra quão recente (LOPES, 2008) é o campo história das ciências/do gênero. Entretanto, se pensarmos que a

\footnotetext{
${ }^{1}$ Ver, também, Qual foi o impacto do feminismo na ciência?, artigo publicado em Cadernos Pagu (FOX-KELLER, 2006).
} 
história das ciências existe como disciplina desde o século XIX, podemos entender historicamente a invisibilidade das mulheres, uma vez que a ciência se torna defensora da superioridade cultural da civilização ocidental. Já as mulheres, a partir desse mesmo período, seriam cada vez mais identificadas e simbolizadas pela maternidade e pela natureza não ordenada.

Entretanto, é válido ressaltar que sua vertente social e cultural surgiu apenas depois da década de 1980 (LOPES, 2006b). Por essa razão, para que os estudos de gênero e ciência se expandam, é necessário que se transcenda a visão de que a única possibilidade de existência de um fazer científico nos séculos passados no Brasil fosse masculina, dado que o acesso das mulheres às universidades, no Brasil, deu-se apenas em 1879.

Assim, o movimento historiográfico deveria ser de "recuperar, avançar e criar novas tradições, que nos permitam tornar visíveis as mulheres e as relações de gênero em nossos fazeres científicos" (LOPES, 1998, p. 366).

Além disso, Foucault (2007) menciona que a história não é feita só do que está escrito, mas também do que está implícito e dos silenciamentos. Caberia, então, pesquisar em outros tipos de espaços públicos ou privados para o período anterior a 1879. Dessa forma, os estudos de gênero e história das ciências trazem à baila um novo campo de investigação, que lida com a construção e a naturalização "das diferenças de sexo e gênero". Para Löwy (2000, p.22/23), a solução "[...] de continuidade entre o social, o cultural e o político na construção da natureza feminina ou masculina tornou-se uma das preocupações principais dos historiadores/as das ciências interessados/as nas questões de gênero".

Outros marcos foram surgindo, no decorrer do tempo, postergando a entrada das mulheres como sujeitos históricos na produção da ciência moderna. A literatura científica demonstra 
que as pesquisas apontam, entre outras coisas, para um aumento significativo das mulheres no ensino superior no Brasil a partir de 1970 (AZEVEDO; FERREIRA, 2006; AZEVEDO et al., 2004; MELO; RODRIGUES, 2006; GUEDES, 2008) e que representam a maioria nos cursos universitários (COSTA, 2006). Os dados mostram também que as mulheres passam mais tempo estudando do que os homens, e a hipótese levantada por Moema de Castro Guedes (2008) é que isso ocorre devido às escassas oportunidades de trabalho. Entretanto, Osada e Costa (2007) apontam que, apesar de os níveis de escolaridade das mulheres serem iguais ou até maiores, encontramos mais homens do que mulheres em cargos de chefia, pois a equiparidade quantitativa não significa igualdade de condições sociais entre os gêneros (AZEVEDO; FERREIRA, 2006; AZEVEDO et al., 2004; GUEDES, 2008; FERREIRA et al., 2008).

Outro problema enfrentado pelas mulheres pesquisadoras seria a falta de práticas que incentivem questões femininas, como no caso da maternidade, pois não existem políticas específicas de apoio, chegando a casos de cortes de bolsa em períodos de afastamento por maternidade (OSADA; COSTA, 2007).

Entretanto, questões como maternidade e casamento devem ser observadas de uma forma mais ampla e complexa, e não entendidas como os únicos fatores determinantes para que as mulheres não ocupem tantos cargos de chefia, publiquem menos, publiquem textos com mais colaboradores ou até abandonem a carreira de pesquisadoras (FERREIRA et al., 2008).

Assim, um dos mais importantes incentivos às mulheres na produção científica são bolsas, prêmios, apoios às pesquisas e intercâmbios, estimulando a manutenção da mulher no campo científico. A criação do CNPq em 1951 (FERREIRA et al., 2008; LOPES; SOUZA; SOMBRIO, 2004; AZEVEDO et al., 2004; 
AZEVEDO, CORTES E SÁ, 2008), por exemplo, é um marco nesse aspecto, pois a entidade custeou pesquisas de várias cientistas, tais como: Bertha Lutz (SOUZA; SOMBRIO; LOPES 2005; ANGÓS, 2008), Leda Dau e Aída Vassón-Voloch. Sobre essas mudanças, podemos afirmar que:

[...] ensejaram o aparecimento de condições institucionais que permitiram tornar a ciência uma opção para um contingente expressivo de mulheres que, valendo-se das estratégias e dos modelos profissionais então disponíveis, contribuíram para a redefinição das balizas que demarcavam as relações de gênero no Brasil. (AZEVEDO; CORTES; FERREIRA, 2008).

Pudemos observar que as mulheres que integraram os quadros de pesquisas do Brasil até os anos 1970 tiveram dois fatores fundamentais que as auxiliaram na escolha e permanência na profissão: o apoio da família e uma situação financeira mais estável (MELO; RODRIGUES, 2006; AZEVEDO et al., 2004; AZEVEDO; CORTES; FERREIRA, 2008; OLIVER; FIGUEIRÔA, 2007). A química Aída Vassón-Voloch (AZEVEDO et al., 2004), por exemplo, contou com o incentivo de seu pai para que estudasse, pois este deu suporte financeiro para que Aída ingressasse no curso e iniciasse a carreira.

Já a botânica Leda Dau comenta da importância do incentivo de seu irmão para que ingressasse na carreira de cientista (AZEVEDO et al., 2008). Com base nesses dados, podemos afirmar que, para que essas mulheres tivessem acesso à educação e à carreira de cientistas, precisaram do que chamamos de rede de apoio, que pode vir da família e/ou das agências de fomento. E, no campo educacional, entendemos que, para essas e outras mulheres - que Melo e Rodrigues (2006) chamam 
de pioneiras da ciência no Brasil -, a reformulação da educação ocorrida a partir dos anos 1920 e 1930 foi fundamental para o seu ingresso no ensino superior (FERREIRA et al., 2008).

Os anos 1920 são apontados como o contexto no qual foram formuladas as ideias fundamentais e empreendidas as ações pioneiras que lançaram as bases institucionais da moderna organização escolar brasileira, consolidadas nos anos 1930 e 1940 do século XX (AZEVEDO; FERREIRA, 2006).

Já a reforma educacional promovida pelo Ministério da Educação em 1942, que culminou na criação da UFRJ, e a "reforma do ensino secundário" tiveram um papel importante na legitimação da relação entre classes sociais, raças e gênero. Entretanto, para as mulheres, coube o ensino doméstico e o ensino normal, pois estes podem ser relacionados com a família e a administração do lar (AZEVEDO et al., 2004). Nesse sentido, a urbanização e as relações de gênero se estabelecem na sociedade capitalista continuando o modelo de distribuição de papéis preestabelecidos, restringindo a participação das mulheres em profissões que são consideradas inadequadas para elas. Essa relação de adequabilidade das profissões está baseada na ideia de que as mulheres são mais aptas às artes e à literatura, e os homens às ciências, pois eles são mais pragmáticos nas relações (AZEVEDO et al., 2004; GUEDES, 2008).

Isabel Guérin (2005) chama essa relação de "altruísmo", cuja definição seria essa designação que se dá à mulher ao assumir o papel de cuidadora, pois, nas sociedades antigas, o ser mulher estava relacionado com um dom, por isso era comum que as mulheres se ocupassem de tudo que se relacionasse ao cuidado do outro.

A especialização das mulheres nas atividades de proximidade não pode ser interpretada a partir de um 
fator único. Ela resulta de uma pluralidade de fatores em que as aspirações pessoais e a preocupação com outrem se entrecruzam com pressões de diversos graus, desde o imperativo da sobrevivência até o simples respeito às normas sociais em vigor, passando pela interiorização de um senso do dever e da dedicação. (GUÉRIN, 2005, p. 38).

O termo "atividade de proximidade" foi cunhado por Nancy Folbre e significa o "envolvimento das mulheres no cuidar de outras pessoas". A entrada das mulheres no mercado de trabalho teria a potencialidade de reforçar a segregação profissional de gênero, pois as mulheres ocupariam em larga escala profissões que remetem ao cuidado com o outro (GUÉRIN, 2005, p. 39). Sendo assim, "[...] definitivamente, seja em sua família ou enquanto assalariadas, as mulheres são conduzidas, mais que os homens, a exercer um 'trabalho afetivo' que pressupõe 'competências de educadora e mediadora'” (GUÉRIN, 2005, p. 40).

As mulheres são mais encontradas em profissões de cuidado, tais como professora, babá, secretária, enfermeira, empregada doméstica. $\mathrm{E}$, na maioria dos casos, as mulheres são mais vistas em atividades não remuneradas do que os homens, mas isso seria uma questão de gênero, pois esse "altruísmo" feminino estaria ligado a um mecanismo de exploração e dominação das mulheres, que tornaria a mulher alienada, alheia e "despossuída de seu corpo ou de sua força de trabalho" (GUÉRIN, 2005, p. 41). As mulheres sempre trabalharam, já que cuidavam de seus lares e faziam esses trabalhos não remunerados, o que muda nesse sentido é o contexto da industrialização e urbanização, levando as mulheres para o trabalho fora de casa, mas mantendo-as nessas profissões de cuidados, como se fosse a sua única vocação trabaIhar com o cuidado dos outros e das coisas. 
Oliver (2009, p. 233) discorre sobre a educação das muIheres da classe alta, que visava suprir as necessidades do lar e da criação dos filhos dentro dos padrões adequados de conduta, e sempre concentrada na manutenção da saúde das crianças. Desde o final do século XIX, as mulheres passaram a frequentar espaços públicos e a obter uma escolaridade que desse suporte às "obrigações femininas", pois a mulher teria o cuidado do lar como vocação. Apesar dessa relação entre mulher e lar, a autora se debruça sobre os locais e papéis que essas mulheres perfazem no contexto do fazer científico. Questiona-se sobre onde estão as mulheres no campo científico, principalmente na agronomia, e qual o perfil das esposas dos cientistas (OLIVER, 2009).

Oliver (2009, p. 230) cita o livro Psicología General², publicado em 1927, que discute também quais as características das esposas desses cientistas e traz a seguinte afirmação: "Os autores argumentam que as esposas ideais deveriam ter como características a iniciativa própria e a capacidade de cuidar do lar e da família sozinhas". Essa mulher deveria ter como característica principal dar total suporte ao marido, poupando-o de situações que possam promover desgastes físicos ou mentais que atrapalhem a sua pesquisa, e também basear todas as suas ações em informações obtidas por meio da divulgação científica.

Londa Schiebinger (2008, p. 274) chama essa relação hierárquica obtida pelo casamento de hipergamia, pois afirma que as mulheres têm a tendência de casar-se com homens de status superior ao delas, pois o reconhecimento social feminino se dá pelo casamento. Nesse sentido, afirma que, hoje em dia,

2 SANCHEZ, José Rogério; EGIDIO, Vicente Feliu. Psicología General, Madrid: Hernando, 1927. 
as mulheres ${ }^{3}$ cientistas tendem a casar com homens também cientistas, e que uma parcela considerável se relaciona com parceiros da mesma área acadêmica.

A pesquisa de Oliver (2009, p. 231) trata do ensino de agronomia no Brasil e, entre os diversos elementos trazidos neste contexto, discutiu, também, a inserção da mulher nas escolas de agronomia de nível superior entre os anos de 1930 e 1950. Em análise de 2.082 registros desse período, Oliver encontra somente 21 mulheres matriculadas, concluindo que se podem encontrar mais mulheres nos cursos de "arquitetura e de engenharia química" do que nos de agronomia. Neste contexto de profissão, predominantemente masculino, o primeiro elemento feminino antes de 1930 é a imagem de Ceres nos quadros de formatura, bem como as referências escritas à própria escola como uma figura feminina. (OLIVER, 2009, p. 231).

Graciela de Souza Oliver e Sílvia Fernanda de Mendonça Figuerôa (2007, p. 379) realizam uma análise dessas imagens de Ceres, que é uma figura emblemática nos quadros de formatura da época. Em um primeiro momento, fazem referência a Londa Schiebinger e relatam que Ceres é representada "sempre no plano inferior dos quadros", legitimando, assim, sua posição de musa. A imagem de Ceres foi interpretada de duas maneiras: "como a mulher que semeia ou como a mulher guardiã".

Logo, as duas interpretações coadunam o entendimento que se tem do "papel social da época", ou seja, Ceres faz a ligação entre a escola agrícola e o lar, mas também sua imagem demonstra que podemos entender que existe uma vocação científica que faz sentido ao agrônomo, um local específico para ela. Na esfera do discurso textual, a Casa de Ceres, como

${ }^{3}$ A autora se refere a mulheres heterossexuais e Cis em sua pesquisa. 
lugar feminino, sacraliza o Templo da Ciência, onde se aprendem os primeiros passos no domínio da natureza e da agricultura (OLIVER; FIGUEIRÔA, 2007, p. 380-381).

Nas relações entre o campo, as ciências e suas relações com a agronomia, coube às mulheres o papel coadjuvante; sendo assim, somente nove daquelas 21 engenheiras agrônomas formadas se voltaram para o campo do experimento. Entretanto, apesar de terem sido uma minoria na área, essas mulheres representaram novas possibilidades de profissionalização para outras mulheres, que puderam ingressar na carreira (OLIVER; FIGUEIRÔA, 2007, p. 392-393). E é por isso que estudar história das ciências e gênero é tão importante para a visibilidade feminina, pois "[...] essas 'invisíveis' mulheres construíram suas carreiras no passado e continuam a construí-las, mesmo em áreas ainda consideradas masculinas como a Informática" (LOPES; SOUZA, 2007). Mas, além disso, consideramos importante entender quais relações podem ter surgido entre as ciências e as mulheres, quais discursos e contextos podem ter afastado as mulheres das diferentes práticas científicas e transformado essas práticas, no cotidiano praticado pelo senso comum, em um lugar da ação masculina.

\section{Considerações finais}

Ao relacionarmos mulher e ciência, a primeira coisa que podemos apontar é o aparente distanciamento entre ambas. Esse processo - ou tentativa - de afastamento se dá desde os primeiros momentos de socialização, quando as mulheres são direcionadas às atividades marcadas como "femininas". Essas "características" também são utilizadas para justificar e incentivar as mulheres a 
se aproximarem das ciências humanas e se afastarem das ciências naturais (COSTA, 2006).

A objetividade, a universalidade, a neutralidade científica e o determinismo tecnológico são algumas das características da ciência mais criticadas pela epistemologia feminista. Mas, segundo Lopes (2006a), as imagens dos ideais de "masculinidade da cultura moderna europeia" também podem ser entendidas como uma causa reconhecida para a "invisibilidade das mulheres em ciências", e quem sabe até mais do que a objetividade como fator principal da exclusão feminina.

Ao analisar casos específicos, como os breves exemplos abordados aqui, conclui-se que, a cada tempo e contexto, a invisibilidade permaneceu paralelamente ao relativo aumento de brechas e oportunidades sociais e no campo científico.

Por essa razão, Hilton Japiassú (2001, p. 67-83) afirma que "[...] a ciência moderna é portadora de uma dimensão tipicamente machista [...]", pois seria um universo de controle produtivo e que possuiria um código masculino, assim, essa linguagem científica seria baseada num universo "patriarcal, masculino e machista".

A ciência, então, buscaria elaborar conceitos que dominariam a natureza, dando o controle aos homens, e esse movimento seria normatizante, já que "[...] pela ciência que o homem tem acesso à realidade [...]. Porque se apresenta como o melhor conhecimento"; por isso, surge a necessidade de abordar todas as situações "cientificamente" (JAPIASSÚ, 2001, p. 73), ordenando a esfera pública do conhecimento. Podemos entender que o uso da linguagem científica nas esferas públicas propiciaria também a produção e reprodução da modernidade e de suas características de gênero. 
Além do discurso científico normatizante - que é amplamente divulgado e baseado na necessidade do "comprovado cientificamente", reproduz-se a dicotomia da ciência, que se baseia, antes de tudo, na relação masculino e feminino, que é a mesma do racional/irracional, da objetividade/sensibilidade, do público/privado. Essa dualidade somente reforça as relações de gênero no discurso e no fazer científico, podendo sinalizar, em diversos contextos, que esse fazer não era, ou é, para as mulheres.

Entretanto, como mostramos ao longo do texto, a história das ciências e gênero é também um campo científico que problematiza o trabalho de pesquisa feminina nas ciências, desconstruindo o discurso binário que diferencia características masculinas e femininas e que direciona a mulher ao privado, profissões de cuidado, afirmando a existência de uma incapacidade feminina de lidar com questões lógicas e práticas. Dessa forma, o lugar das mulheres - cujas práticas científicas, desenvolvidas ao longo da história, foram muito importantes - também é nas ciências.

\section{Referências}

ANGÓs, Teresa Nuño. Consideraciones sobre género y ciencias en la trayectoria feminista de Bertha Maria Júlia Lutz (18941976). In: MIQUEO, Consuelo Miqueo et al. (Coord.). Estudios iberoamericanos de género en ciencia, tecnología y salud. Espanha: Prensa Universitária de Zaragoza, 2008. p. 509-514

AZEVEDO, Nara; CORTES, Bianca Antunes; FERREIRA, Luiz Otávio; SÁ, Magali Romero. Gênero e ciência: a carreira científica de Aída Hassón-Voloch. Cadernos Pagu, Campinas, v. 23, p. 355387, jul./dez. 2004. 
; ; .; Um caminho para a ciência: a trajetória da botânica Leda Dau. História, Ciência, Saúde - Manguinhos, Rio de Janeiro, v. 15 (suplemento), p. 209-229, jun. 2008.

.; FERREIRA, Luiz Otávio. Modernização, políticas públicas e sistemas de gênero no Brasil: educação e profissionalização feminina entre as décadas de 1920 e 1940. Cadernos Pagu, Campinas, v. 27, p. 217-220, jul./dez. 2006.

COSTA, Maria Conceição da. Ainda somos poucas: exclusão e invisibilidade na ciência. Cadernos Pagu, Campinas, v. 27, p. 455459, jul./dez. 2006.

FERREIRA, Luís Otávio; AZEVEDO, Nara; GUEDES, Moema; CORTES, Bianca. Institucionalização das ciências, sistema de gênero e produção científica no Brasil (1939-1969). História, Ciências, Saúde-Manguinhos, Rio de Janeiro, v. 15 (suplemento), p. 43-71, jun. 2008.

FOUCAULT, Michel. Microfísica do poder. São Paulo: Graal, 2007.

FOX-KELLER, Evelyn. Qual foi o impacto do feminismo na ciência? Cadernos Pagu, Campinas, v. 27, p. 13-34, jul./dez. 2006.

GUEDES, Moema de Castro. A presença feminina nos cursos universitários e nas pós-graduações: desconstruindo a ideia da universidade como espaço masculino. História, Ciência, Saúde - Manguinhos, Rio de Janeiro, v. 15 (suplemento), p. 117-132, 2008.

GUÉRIN, Isabel. As mulheres e a economia solidária. São Paulo: Edições Loyola, 2005.

HARDING, Sandra. A instabilidade das categorias analíticas na teoria feminista. Estudos Feministas, v. 1, n. 1, p. 7-31, jan./ jun.1993. 
. Ciencia y Feminismo. Madrid: Ediciones Morata, 1996.

JAPIASSÚ, Hilton. O projeto masculino-machista da ciência moderna. In: SOARES, Luiz Carlos (Org.). Da Revolução Científica à Big Science. São Paulo: Mussite/EDUFF, 2001. p. 67-104.

LOPES, Maria Margaret. O Brasil descobre a pesquisa científica: os museus e as ciências naturais no século XIX. São Paulo: Hucitec, 1997.

- "Aventureiras" nas Ciências: refletindo sobre Gênero e História das Ciências Naturais no Brasil. Cadernos Pagu, Campinas, v. 10, p. 345-368, 1998.

. Apresentação. Cadernos Pagu, Campinas, v. 27, p. 9-11, $2006 a$.

- Sobre as convenções em torno de argumentos de autoridade. Caderno Pagu, Campinas, v. 27, p. 35-61, $2006 \mathrm{~b}$.

. Apresentação ao artigo de Londa Schiebinger. História, Ciências, Saúde-Manguinhos, Rio de Janeiro, v. 15 (suplemento), p. 269-281, jun. 2008.

. SOUSA, Lia Gomes Pinto de. Mulheres nas ciências naturais: produção científica de Bertha Maria Júlia Lutz (18941976), a partir da década de 1940. In: SILVA, Cristiani Bareta da; ASSIS, Gláucia de Oliveira; KAMITA Rosana Cássia et al. (Org.). Gênero em movimento: novos olhares, muitos lugares. Florianópolis: Editora Mulheres, 2007. p. 59-74.

; ___ SOMBRIO, Mariana Moraes de Oliveira, A construção da invisibilidade das mulheres nas ciências: a exemplaridade de Bertha Maria Júlia Lutz (1894-1976), Gênero - NUTEG, v. 5, p. 97-109, 2004. 
LÖWY, Ilana. Universalidade da ciência e conhecimentos "situados". Cadernos Pagu, Campinas, v. 15, p. 15-38, 2000.

MELO, Hildete Pereira de; RODRIGUES, Ligia M. C. S. Pioneiras da ciência no Brasil. Rio de Janeiro: Sociedade Brasileira para o Progresso da Ciência, 2006.

NYHART, Lynn; BROMAN, Thomas. Science and Civil Society. Osiris 17. Chigaco: University of Chicago Press, 2002.

OLIVER, Graciela de Souza, Institucionalização das ciências agrícolas e seu ensino no Brasil, 1930-1950. São Paulo: Annablume, 2009.

.; FIGUEIRÔA, Silvia Fernanda de Mendonça. Ceres, as mulheres e o sertão: representações sobre o feminino e a agricultura brasileira na primeira metade do século XX. Cadernos Pagu, Campinas, v. 29, p. 365-397, jul./dez. 2007.

OSADA, Neide; COSTA, Conceição. A construção da Nova Biologia: relações de gênero nos laboratórios do Projeto Genoma da Fapesp. Cadernos de gênero e tecnologia, Curitiba, ano 3, n. 11, p. 21-34, 2007.

PEDRO, Joana; GROSSI, Miriam (Org.). Masculino, feminino, plural. Florianópolis: Ed. Mulheres, 1998.

SARDENBERG, Cecília Maria Bacellar; COSTA, Ana Alice Alcântara (Org.). Feminismo, Ciência e Tecnologia. Salvador: Rede Feminista Norte e Nordeste de Estudos e Pesquisa sobre Mulher e Relações de Gênero (REDOR), Núcleo de Estudos Interdisciplinares sobre a Mulher (NEIM), Universidade Federal da Bahia, 2002. v. 8. (Coleção Bahianas). 
SCHIEBINGER, Londa. Mais mulheres na ciência: questões de conhecimento. Apresentação de Maria Margaret Lopes. História, Ciências, Saúde - Manguinhos, Rio de Janeiro, v. 15 (suplemento), p. 269-281, 2008.

SOUZA, Lia Gomes Pinto de; SOMBRIO, Mariana Moraes de O.; LOPES, Maria Margaret. Para ler Bertha Lutz. Cadernos Pagu, Campinas, n. 24, p. 315-325, 2005. 


\section{GÊNERO E CIÊNCIA: ANÁLISE DE UMA POSSÍVEL CIÊNCIA FEMINISTA}

\section{Andréia Moreira da Silva Karla Rampim Xavier Ana Maria Dietrich}

\section{Introdução}

O estudo de gênero é um fenômeno que pode significar uma revolução científica, ou, até mesmo, revolucionar o modo de fazer ciência, pois pode alterar concepções, padrões sociais, religiosos e políticos, ligados a determinismos científicos pautados no sexismo biológico. $\mathrm{O}$ saber científico validou discursos que colocaram socialmente a mulher como inferior, intelectual e fisicamente, frente ao homem detentor, produtor e disseminador de saberes, incluindo sobre o próprio corpo e a sexualidade da mulher.

O feminismo traz novas perspectivas a esse fazer científico, colocando em foco tais discursos e os desconstruindo, mostrando ser possível outro tipo de ciência que valoriza as diferenças nas concepções de mundo, promovendo uma ressignificação no papel da mulher na história da ciência. Nesse texto, pretende-se, principalmente do ponto de vista da psicanálise, 
analisar se podemos dizer que existe hoje, de fato, uma ciência feminista, e quais são suas especificidades.

\section{História e psicanálise}

Sigmund Freud (1856-1939) é mundialmente conhecido por ser o criador da psicanálise. Sua descoberta sobre o inconsciente mudou a forma de pensarmos o sujeito humano e sua relação com o campo social. A teoria de Freud pode reiterar certos estereótipos de gêneros se for lida fora do período e do contexto em que foi escrita, todavia, simultaneamente, Freud se mostra à frente do seu tempo, como podemos notar com a seguinte afirmação de 1925: “[...] todos os indivíduos humanos, em resultado de sua disposição bissexual e da herança cruzada, combinam em si características tanto masculinas quanto femininas, de maneira que a masculinidade e a feminilidade puras permanecem sendo construções de conteúdo incerto" (FREUD, 1925/2010, p. 286).

Sigmund Freud não era um cientista que pensava o feminismo, mas investigava sobre a sexualidade e as diferenças subjetivas entre homens e mulheres. Seu encontro com os médicos Jean Martin Charcot (1825-1893) e Josef Breuer (1842-1925) foi fundamental para a invenção de um novo método de trabalho, chamado de associação livre, que é a regra de ouro para o tratamento analítico. $O$ Doutor Freud pedia para seus pacientes falarem espontaneamente o que pensavam, e, desse modo, deu voz a essas pessoas, sendo a maioria mulheres. Tal fato, decorrente em pleno século XIX, abriu novas possibilidades para pensar sobre o desejo feminino, a construção subjetiva na cultura e o lugar das mulheres na história. 
Ao longo do desenvolvimento da psicanálise, a teoria sobre sexualidade foi avançando e com ela o conceito de gênero, mas é com o psicanalista francês Jacques Lacan (1901-1981) que podemos observar uma mudança significativa a respeito da sexuação e da alteridade feminina para a psicanálise, especialmente nos anos 1970 e com a efervescência das feministas que militavam na França.

Identidade, diferença e alteridade permitem, desde Freud, ver os becos sem saídas nos quais, quando se quer definir o que é uma identidade sexual, aparece todo o problema entre sexualidade como pulsão, ou seja, como satisfação, e a identidade em relação a como um sujeito pode se dizer homem ou mulher. (GALLANO, 2011, p. 55)

Desde o início de suas pesquisas e seminários, Lacan evidencia a sua diferença em relação ao pensamento de os outros pós-freudianos sobre a questão da feminilidade. Ele demonstra que há uma determinação linguística que forma os sujeitos humanos desde o seu nascimento, e é esta condição indissociável entre o humano e a linguagem que possibilita o inconsciente, a partir daí forma-se a sexualidade, as identidades e o gênero. Lacan faz mais do que evidenciar ou retomar afirmações e articulações de Freud, na medida em que demonstra que a feminilidade e a masculinidade são posições construídas e estruturadas a partir da combinatória de certos elementos (PACHECO, 2001, p. 63).

Isso significa que, para a psicanálise, existem diferenças entre homens e mulheres que acabam por estruturar o gênero, o modo de pensar e agir socialmente, e consequentemente influenciam o modo de fazer ciência. As mulheres escritoras marcam novos ideais e contribuem no campo das identificações de 
gênero, acrescentando outras questões até então desenvolvidas historicamente no campo da ciência.

A imagem da mulher foi modificada com o passar dos anos. Maio de 1968 é um marco histórico para o avanço do feminismo no mundo, apesar de que alguns passos já vinham sendo dados desde o pós-guerra e a Revolução Industrial. No ano de 1968, o feminismo e a discussão de gênero apareceram como um avanço simbólico que fez desencadear diversas outras conquistas.

Podemos lembrar que, em gerações passadas, o uso das "calças compridas" não era possível para as mulheres, assim como eram vetados a estas o direito aos estudos, a frequentar universidades e espaços públicos. Com o avanço da ciência e das conquistas históricas, abriram-se novas possibilidades para as mulheres.

A pílula anticoncepcional, por exemplo, tornou possível dissociar a procriação do prazer sexual, algo libertador na vida das mulheres, ou mesmo a entrada no mundo do trabalho com as mesmas funções dos homens. Entretanto, aqui cabe ressaltar que não há ainda equiparação salarial. De qualquer modo, podemos notar avanços que são frutos da luta feminista, e que esta luta precisa ser contínua até que se equiparem os direitos, respeitando as diferenças.

Quais eram os recursos das mulheres no século XIX? Sabemos que as mulheres já influenciavam na ciência, mas isso se dava de modo velado, e os homens eram quem levavam os títulos e louros das descobertas das mulheres, que se mantinham anônimas.

Isoladas e no anonimato, hoje é sabido que, ao longo dos anos, algumas mulheres usaram pseudônimos masculinos ou parcerias com colegas homens para poderem desempenhar uma vida de pesquisadoras. As biografias das primeiras 
mulheres cientistas estão permeadas por esses fatos. As mulheres têm um papel fundamental para o avanço da ciência como podemos observar nas breves biografias abaixo:

Marie Curie (1867-1934) - física e química polonesa ficou conhecida por suas contribuições sobre radioatividade, ganhou o Prêmio Nobel de Física de 1903 e o Prêmio Nobel de Química de 1911, tornando-se a primeira pessoa a conquistar o Nobel duas vezes e em áreas diferentes; Rita Levi-Montalcini (1909-) - neurologista italiana - recebeu o Prêmio Nobel de Fisiologia/Medicina de 1986 pelos seus estudos sobre o sistema nervoso; Jane Goodall (1934-) - primatologista e etóloga britânica - ficou conhecida em todo o mundo por suas pesquisas sobre chimpanzés; Gertrude Elion (1918-1999) - bioquímica e farmacêutica britânica - recebeu o Prêmio Nobel de Fisiologia/Medicina de 1988 pela criação de novos medicamentos; Marie-Sophie Germain (1776-1831) - matemática, física e filósofa francesa - fez extraordinárias contribuições para a teoria dos números, sendo um dos seus estudos mais importantes a descoberta do que hoje é conhecido como "números primos de Sophie Germain". Ciente das barreiras construídas pelo machismo e com receio de ser ridicularizada, ela assinava seus feitos e descobertas, usando nome masculino (REDAÇÃO SUPER, 2015, p. 15).

Cabe lembrar que as mulheres se rebelaram, há séculos, na polis. Algumas foram queimadas em praças públicas na Idade Média, outras, há décadas, queimaram sutiãs, também em praças públicas. Nesse contexto, o espaço público era considerado dos homens, enquanto para as mulheres estavam reservados os espaços privados.

O feminino atravessou deslocamentos ao longo da história, e muitos avanços se sucederam desde o início do movimento feminista. Notemos que Freud escutava mulheres no início 
do século XIX e isso, naquele tempo, foi algo subversivo por ousar fazer apontamentos sobre a sexualidade, o inconsciente e o campo social.

Em diálogo com essa teoria, a psicanálise afirma que o sexo se trata da diferença anatômica; já o gênero se refere às diferenças culturais de um ideal do que é ser homem e o que é ser mulher.

A psicanalista Rithée Cevasco (2010) investiga a questão feminina e a discordância entre os sexos. Em sua investigação, ela chega à conclusão que falar da discordância entre os sexos não é o mesmo que falar da diferença, sendo assim optou por usar o termo discordância, por não se tratar das diferenças entre os sexos, mas sim de duas posições culturais: a feminina e a masculina. "Efetivamente o campo que venho trabalhando é que poderia chamar a questão feminina, a questão feminina como sintoma, como um sintoma da cultura" (CEVASCO, 2010, p. 17).

Nesse sentido, é interessante o avanço da psicanalista, colocando o feminino como sintoma; afinal, para a psicanálise, "[...] sintoma é aquilo que existe e afirma seu oposto, o conteúdo recalcado que aparece na forma de sintoma denunciando a própria lógica do recalque, bem como implica uma verdade nas falhas do saber" (XAVIER, 2013, p. 12-13).

De acordo com a afirmação, o feminino é um sintoma da sociedade moderna, já que esta, após a Revolução Francesa, passou a buscar liberdade, igualdade e fraternidade para todos, exceto crianças e mulheres. Desse modo, as reivindicações feministas denunciam a inconsistência dessa promessa de igualdade para todos.

Esse debate sobre o feminino se torna pertinente principalmente a partir dos anos 1960, quando os movimentos feministas passam a falar cada vez mais sobre a sexualidade e o 
feminismo, e este debate se dá por duas vias: da diferença ou da igualdade, de acordo com as linhas teóricas apresentadas até então. Ademais, o movimento LGBTS propõe um novo ordenamento do campo sexual, um novo caminho não presente nos campos tradicionais, e isso se deu através de lutas políticas reivindicativas.

As representantes da vanguarda do chamado "feminismo da diferença" partiam da base que havia uma radical diferença entre homens e mulheres no inconsciente. Entre 1972 e 1973, Lacan ministrou um seminário no qual recusou tal posição, afirmando que o inconsciente não tem sexo.

Para Cevasco (2010), ao analisar Freud, a mulher sempre se coloca mais ao lado da natureza do que da cultura. As mulheres teriam certo gozo inquietante, porém perigoso. Freud passa a se ocupar do que queriam as mulheres. Passa então a reconhecer os limites do seu próprio pensamento em suas reflexões que afirmavam que o papel da mulher era o de mãe.

Mas de que modo a construção teórica pensada a partir de Freud e Lacan tem relação com gênero e ciência? A lógica masculina é a que cria, em termos epistemológicos, a tríade do que é considerado como universal, como exceção e como estranho. Tal pensamento pode estimular guerras contra o diferente, contra o estranho - como aconteceu no caso dos judeus na Segunda Guerra Mundial. Daí a formulação lacaniana do não todo aparece como algo diverso dessa lógica, uma saída "feminina", já que, por não universalizar, não exclui.

No livro La discordancia de los sexos, Cevasco (2010) recorre ao filósofo Alain Badiou, que afirma que o feminino é esse entre dois, nem um nem dois, apostando que no futuro teremos uma sociedade com menos virilidade, que se preocupe menos em dar respostas, em fechar questões, para poder abrir 
pensamentos e possibilidades para além da lógica fálica, apontando para outra forma de fazer ciência.

\section{Existe uma ciência feminista?}

Pensar uma ciência feminista é raciocinar qual é a verdade sobre a mulher, é ponderar a mulher como sujeito ${ }^{1}$ e refletir sobre sua forma de se relacionar com o universo e com os outros de forma dinâmica, fomentando a construção de saberes com algo tão peculiar e que está em constante mudança.

Por via da linguagem, essa possível ciência feminista se estabelece e por essa mesma via os sujeitos internalizam esses saberes, em um processo constante e dinâmico com a sociedade. "O sujeito é sempre um ser de linguagem, isto é, de cultura, inscrito sob as coordenadas de um certo período histórico, de uma certa sociedade, de uma certa disposição simbólica" (KEHL, 2008, p. 254).

No entanto, observando-se a trajetória da produção científica sobre o feminino, durante séculos ela foi constituída como saber transcendental, como verdade incontestável, afastando, durante esse período, as mulheres da produção de conhecimentos sobre seu próprio corpo, sua sexualidade seus direitos civis e do acesso às universidades, e que tornou o questionamento da ciência antropológica uma barreira difícil de transpor.

Com o levante dos movimentos feministas na década de 1960, questionou-se a necessidade de estudos e pesquisas

\footnotetext{
1 Em 1900, na Interpretação dos Sonhos, Freud desvela as leis do inconsciente fazendo emergir o sujeito do desejo como sujeito determinado pelas leis da linguagem, ou seja, por leis em que as palavras são tratadas como puros sinais sonoros, significantes sem significado, por onde desliza o desejo (QUINET, 2003, p. 16).
} 
voltados para a problemática da mulher e, a partir de então, começaram a ser construídos espaços para que esses estudos conquistassem relevância e alcançassem as universidades.

Inicialmente caracterizado como estudos sobre muIheres, e mais tarde, com a construção do conceito de gênero, também como estudos de gênero e, mais recentemente, como estudos feministas, esse campo emergente vem se institucionalizando no Brasil desde os anos 1970. Vale destacar que, desde o início das lutas feministas no contexto do movimento social, a teoria e a práxis têm estado estritamente veiculadas, uma contribuindo para o avanço da outra. (BRASIL, 2010, p. 55)

Podemos afirmar que existe uma ciência feminista e ela está diretamente integrada às dinâmicas e demandas dos movimentos feministas, da militância e da necessidade das mulheres. A ciência se faz da necessidade de conhecimento para que se possa evoluir, de certa forma toda mulher feminista pode ser uma cientista, produzindo conhecimento com sua causa e sua ação, ao contrário do valor simbólico que a ciência tem no senso comum, de verdade incontestável, ciência também se faz de necessidades cotidianas, de acordo com determinado grupo de uma determinada cultura.

Nossa preocupação é a de produzir novos parâmetros teóricos e metodológicos que não reproduzam as categorias do sistema de dominação patriarcal, escapando dos símbolos determinados e das categorias abstratas e universais que tentam negar as diferenças e padronizar as pessoas. Sabemos que não é possível continuar aceitando que o sexo biológico determine as posições que os indivíduos podem ocupar na hierarquia social [...]. (BRASIL, 2010, p. 62) 
A ciência feminista caminha na direção de desconstruir saberes naturalizados sobre a mulher e o universo feminino que até então eram construídos pelos homens.

A ideia de que as mulheres formariam um conjunto de sujeitos definidos a partir de sua natureza, ou seja, da anatomia e suas vicissitudes, aparece nesses discursos em aparente contradição com outra ideia, bastante corrente, de que a natureza feminina precisa ser domada pela sociedade e pela educação para que as mulheres pudessem cumprir o destino ao qual estariam naturalmente designadas. (KEHL, 2008, p. 48)

O espaço destinado às mulheres era o privado, a casa, os filhos e a vida doméstica. O casamento e a maternidade eram "naturalmente" os lugares da mulher, não havia possibilidade de escolha. Toda mulher seguiria esse caminho. As mulheres não eram possuidoras nem dos próprios corpos, muito menos dos próprios destinos. As sociedades se valiam de argumentos de que as mulheres não eram qualificáveis para o exercício do sufrágio, nem tinham as faculdades intelectuais necessárias para o exercício de cargos públicos, eram frágeis emocionalmente para suportar as pressões da vida pública, entre outras justificativas. Claramente, por esse motivo, é na desconstrução que sempre trabalhou e continuará trabalhando a ciência feminista.

Dizer que as mulheres não eram possuidoras dos próprios corpos não é exagero. Até 1979, o acesso aos meios de contracepção no Brasil somente era possível por meio de uma indicação médica que atestasse que a gravidez traria risco à saúde da mulher, constituindo ilícito penal sua prescrição. Após esse período, a lei foi revogada, sendo mantida em relação ao aborto, outro aspecto que merece um olhar atento, já que diz respeito à autonomia do corpo da mulher, que é tolhida com base em contextos legais, religiosos e culturais. 
Outro aspecto relevante da desigualdade sofrida pelas mulheres é a objetificação dos corpos. Por meio disso, simbolicamente, o corpo feminino é usado pelos diversos meios de comunicação sob a forma de bens de consumo, como em propagandas de cerveja, programas de esportes, dentre outros, destinados ao público masculino, explorando a sexualidade feminina como mercadoria ou atrativo. "O efeito da dominação simbólica (seja ela de etnia, de gênero, de cultura, de língua etc.) se exerce não na lógica pura das consciências" (BOURDIEU, 2003, p. 49).

A ciência feminista tem a finalidade de (re)construir a história das mulheres, a própria feminilidade, tornando-a uma história mais plural, sem desigualdades.

Posso afirmar o seguinte: a construção da história das mulheres depende delas próprias, mesmo que não estejam diretamente vinculadas a isso. $O$ ponto de partida dessa construção pressupõe certa autonomia e acesso à cultura. No fundo, as mulheres tomam sua história nas mãos da mesma maneira como tomam seu destino nas mãos. (PERROT, 1991, p. 513)

Atributos que conhecemos hoje como feminilidade, atribuídas ao gênero ${ }^{2}$ feminino como qualidades, foram sugeridas pelos homens, embasados nos aspectos naturais dos corpos das mulheres, muitas vezes comparados aos das fêmeas de natureza mamífera, como o comportamento dócil, a espera pelo grande amor, o sonho da maternidade, a facilidade com o cuidar, a passividade, a fragilidade dos corpos, a futilidade contida na

\footnotetext{
2 "O gênero não deve ser meramente concebido como a inscrição cultural de significado num sexo previamente dado [...] tem de designar também o aparato mesmo de produção mediante o qual os próprios sexos são estabelecidos" (BUTLER, 2010, p. 25).
} 
vaidade excessiva, entre outras características ditas femininas. Observam-se essas características do ideal feminino escrito pelo filósofo Rousseau, em seu livro Da Educação, que, por muitas décadas, foi utilizado como um material científico pedagógico na educação das mulheres: "Sofia, que devia se tornar esposa de Emílio, é o paradigma do ideal feminino com base na dedicação, na doçura, na submissão" (1762 apud KEHL, 2008, p. 58).

Como romper com esse constructo social de criação do gênero feminino?

Para explicar as categorias fundacionais de gêneros, Butler vai buscar respostas em Foucault, uma forma de investigação crítica que ele chamou de genealogia.

A crítica genealógica recusa-se a buscar as origens do gênero, a verdade íntima do desejo feminino, uma identidade sexual genuína ou autêntica que a repressão impede de ver; em vez disso, ela investiga as apostas políticas, designando como origem e causa categorias de identidade que, na verdade, são efeitos de instituições, práticas e discursos cujos pontos de origem são múltiplos e difusos. (BUTLER, 2010, p. 9)

Não existe, segundo a autora, a necessidade de que a ciência feminista precise dar conta da identidade primária do gênero feminino para dar continuidade à tarefa política ${ }^{3}$, característica central do movimento. A saída é pela via da negociação para compatibilizar interesses e dar visibilidade política para as mulheres.

Hoje as mulheres conquistaram espaços na política, na universidade, no mercado de trabalho, estão mais independentes, porém as desigualdades persistem. O masculino ainda é o eixo que organiza as sociedades.

3 O termo política aqui se designa àquilo que é público. 
Apesar de todo o "progresso" feminino, as desigualdades persistem em todos os domínios, especialmente no que concerne à decisão política e econômica. A hierarquia dos sexos, que rege a organização das sociedades desde a "noite dos tempos", lembrando aqui expressão da antropóloga Françoise Héritier, não só persiste como não poderá ser abolida rapidamente. É uma transformação de longa duração, um desafio que não se conquista assim, de um momento para o outro, até porque se desdobra em transformações práticas e simbólicas. (PERROT, 1991, p. 514)

Embora tenhamos ultrapassado barreiras disciplinares e paradigmáticas para reafirmar o caráter "das ciências" como construção histórica e produto cultural, existe muito a ser estabelecido para a ciência feminista, sobretudo nos campos políticos e de ensino, espaços públicos de construção do saber.

\section{Referências}

BOURDIEU, Pierre. A Dominação Masculina. Tradução de Maria Helena Kühner. Rio de Janeiro: Bertrand Brasil, 2003.

BUTLER, Judith P. Problemas de Gênero: feminismo e subversão da identidade. Rio de Janeiro: Civilização Brasileira, 2010.

BRASIL. Presidência da República, Secretaria de Políticas para as Mulheres. Pensando Gênero e Ciência. Encontro Nacional de Núcleos e Grupos de Pesquisa - 2009, 2010/ Presidência da República. Brasília: Secretaria Especial de Política para as Mulheres, 2010.

CEVASCO, Rithée. La discordancia de los sexos - Perspectiva psicoanalíticas para um debate actual. Barcelona: Ediciones S\&P, 2010. 
FREUD, Sigmund [1925]. Algumas Consequências Psíquicas da Distinção Anatômica Entre os Sexos. In: . Edição standard brasileira das obras psicológicas completas de Sigmund Freud. Rio de Janeiro: Imago, 2006. v. 19.

GALLANO, Camen. Alteridade Feminina, Campo Grande, MS: Andréa Carla Deuner Brunetto ed,. 2011.

KEHL, Maria Rita, Deslocamentos do Feminino. Rio de Janeiro: Imago, 2008.

REDAÇÃO SUPER. Mulheres que se tornaram grandes cientistas. 7 jul. 2015. Super Interessante. Disponível em: <http://super. abril.com.br/ciencia/15-mulheres-que-se-tornaram-grandescientistas>. Acesso em: 14 abr. 2016.

PACHECO, Ana Laura Prates. Feminilidade e experiência psicanalítica. 1. ed. São Paulo: Hacker, 2001.

PERROT, Michelle. Sair. In: DUBY, George; - (Org.). História das mulheres: o século XIX. Lisboa: Afrontamento, 1991. p. 503-540.

QUINET, Antonio. A descoberta do inconsciente: do desejo ao sintoma 2 ed. Rio de Janeiro: Jorge Zahar, Ed. 2003.

XAVIER, Karla Rampim. O sintoma com Marx ou o sintoma social: um conceito psicanalítico. 2013. 122 f. Dissertação (Mestrado em Psicologia Social) - Programa de Pós-Graduação em Psicologia Social, Pontifícia Universidade Católica de São Paulo, São Paulo, 2013. 


\section{SOBRE OS AUTORES}

Aennder Ferreira de Sousa possui graduação em Licenciatura em Física pela Universidade Federal do Triângulo Mineiro (2013) e Mestrado em Ensino e História das Ciências e da Matemática (2016) pela Universidade Federal do ABC. É membro do grupo de pesquisa História das Ciências na Educação Científica (HSSE) desde 2014. Desenvolve pesquisas em Ensino de Ciências, Cinema, Linguagem Cinematográfica, Cultura e Natureza do Conhecimento Científico. E-mail: aennderfsc@gmail.com

Ana Maria Dietrich é pós-doutora em Sociologia pela UNICAMP-SP, doutora em História (USP-SP/ Universidade Técnica de Berlim) e professora adjunta na UFABC no Bacharelado de Políticas Públicas. Atua no Programa de Pós-Graduação de Ensino e História das Ciências e da Matemática. Líder de grupo de pesquisa do CNPq, Laboratório de Estudos da Contemporaneidade (UFABC), líder de São Paulo do grupo de trabalho da História dos Partidos e Movimentos de Direita na Associação Nacional dos Pesquisadores de História. Coordena o Projeto de Ensino, Pesquisa e Extensão Educação em Direitos Humanos (UFABC), com financiamento do MEC e parceria com a Prefeitura Municipal de São Paulo. Autora dos livros Nazismo Tropical (Todas as Musas, 2012) e Caça às Suásticas (Imprensa Oficial, 2007). É editora dos periódicos acadêmicos Contemporâneos Revista de Artes e Humanidades (www.revistacontemporaneos. 
com.br) e Contemporartes - Revista de Difusão Cultural (www. revistacontemporartes.com.br). Suas pesquisas enfocam os seguintes temas: Traumas de guerra, Estudos de Nazismo e Anti-Semitismo, Identidade e Cultura, Memória, Identidade e Narrativa, Novas Linguagens Historiográficas (Cinema X História, História X Fotografia, História X Canção) e Estudos Interdisciplinares de Artes e Humanidades. E-mail: ana.dietrich@ufabc.edu.br

Andréia Guerra é doutora em Engenharia de Produção pela UFRJ. Professora do Programa de Pós-graduação Ciência, Tecnologia e Educação do CEFET/RJ. Atualmente é bolsista de produtividade do CNPq. Líder do Grupo de Pesquisa História e Filosofia da Ciência no Ensino e atua nas seguintes linhas de formação: a) História e Filosofia da Ciência e Cultura na Educação Científica e Tecnológica; b) História e Filosofia da Ciência e Formação de Professores. E-mail: andreia.guerra96@gmail.com

Andréia Moreira da Silva possui graduação em Psicologia pelo Centro Universitário de Santo André (2006). Atua como Psicóloga na Prefeitura Municipal de Santo André, no projeto "Se liga na parada", sobre questões a respeito de gênero e sexualidade voltadas para jovens da região. É mestranda no Programa de Pós Graduação em Ensino e História das Ciências e da Matemática. E-mail:msandreia@hotmail.com

Breno Arsioli Moura é mestre e doutor em Ensino de Ciências, com ênfase em História da Ciência, pela Universidade de São Paulo $(2008,2012)$ e licenciado em Física pela Universidade Estadual de Campinas (2006). Atualmente, é docente da Universidade Federal do $A B C$, onde desenvolve pesquisas em História da Ciência - especialmente História da Óptica - e na interface entre 
História da Ciência e Ensino. Em 2014, foi professor visitante no Departamento de História da Universidade da Califórnia (Berkeley). É vice-líder do grupo de pesquisa História das Ciências na Educação Científica (HSSE). Na UFABC, orienta no Programa de Pós-Graduação em Ensino e História das Ciências e da Matemática. E-mail: breno.moura@ufabc.edu.br

Clara Guimarães é pesquisadora, ativista feminista e mulher. Estudou Música na Universidade Federal de Pernambuco (2001), graduou-se em Filosofia pela Universidade Metodista de São Paulo (2008) e possui Mestrado em Ensino, História, Filosofia das Ciências e Matemática pela Universidade Federal do ABC (2014). Tem como interesse de pesquisa história das ciências e gênero, epistemologia feminista, filosofia feminista e corpos femininos como práticas de resistência. E-mail: claragui@gmail.com

Danielle Beatriz de Sousa Borges possui graduação em Licenciatura em Física pela Universidade Federal do Triângulo Mineiro (2013) e Mestrado em Ensino e História das Ciências e da Matemática (2016) pela Universidade Federal do ABC. Membro do grupo de pesquisa História das Ciências na Educação Científica (HSSE) desde 2014. Atualmente, cursa especialização em Teorias, Métodos e Práticas para Educação a Distância pela Universidade Virtual do Estado de São Paulo. Desenvolve pesquisa em Ensino de Física/Ciências, História da Termodinâmica no Ensino e Formação Inicial de Professores de Ciências. E-mail:danibsborges@gmail.com

Filipe Faria Berçot é licenciado em Biologia e doutorando no Programa de Pós-Graduação em Ciências Biológicas (Biologia Genética) do Instituto de Biociências da Universidade de São Paulo. 
É pesquisador colaborador no Laboratório de Comunicação Celular, da Fiocruz, atuando em desenvolvimento e avaliação de recursos virtuais para o ensino básico das áreas de Imunologia e Farmacologia. Atualmente, atua no grupo de pesquisa de História da Biologia e Ensino do IB-USP e desenvolve pesquisas em ensino, integrando episódios da História da Biologia como subsídios para o ensino de ciências e sobre a natureza da ciência. E-mail: bercot@ib.usp.br

Graciela Oliver é pesquisadora, ativista e mulher. Possui graduação em História pela Universidade Estadual de Campinas (1998), mestrado em Política Científica e Tecnológica pela Universidade Estadual de Campinas (2001), doutorado em Ensino e História de Ciências da Terra pela Universidade Estadual de Campinas (2005) e Pós-doutorado em História na Universidade Federal de Minas Gerais (2006-2010). Atualmente, atua na Universidade Federal do $A B C$ (UFABC), onde é docente permanente da Pós-graduação em Ensino, História, Filosofia de Ciências e Matemática. Tem experiência em História das Ciências e da Tecnologia, Ciência \& Público e Ciência, Tecnologia e Sociedade. E-mail: graciela.oliver@ufabc.edu.br

Guilherme de Lucas Aparecido Barbosa possui graduação em Ciências e Humanidades pela Universidade Federal do $A B C$ (2016). Atualmente, desenvolve pesquisa nas áreas de Filosofia Moderna, Relações Internacionais e Integração Latino-Americana. Pesquisa com maior ênfase a obra do filósofo inglês Francis Bacon. Tem interesse também nos estudos de Utopias Seiscentistas, Distopias e Literatura Distópica, no eixo da Filosofia. Nas Relações Internacionais, pesquisa os mecanismos institucionais e democracias no Cone Sul. E-mail:glucas@aluno.ufabc.edu.br 
Hélio Elael Bonini Viana é doutor em Química pela Universidade de São Paulo (USP), mestre em Ensino de Ciências - modalidade Química - pela mesma universidade. Gradou-se bacharel e licenciado em Química também pela USP e é engenheiro ambiental pela Universidade Federal de São Carlos (UFSCar). Atuou por quase dez anos como docente da educação básica na rede pública e particular, ministrando aulas de Química e Ciências. Foi docente do Centro Tecnológico Paula Souza e da Univerisdade Federal da Bahia (UFBA). Atualmente, é professor da Universidade Federal de São Paulo, onde, desde 2014, vem realizando pesquisas de cunho interdiciplinar, como a história da técnica e a histórias das ciências ambientais. É integrante do Grupo de Pesquisa em História das Ciências na Educação Científica (HSSE). E-mail:helio_bonini@hotmail.com

Ivã Gurgel é professor do Instituto de Física da Universidade de São Paulo (IFUSP), onde coordena o curso de Licenciatura em Física e orienta mestrados e doutorados no Programa de Pós-Graduação Interunidades em Ensino de Ciências. Possui graduação em Licenciatura em Física (2004), Mestrado em Ciências (Modalidade Ensino de Física, 2006) e Doutorado em Educação (Modalidade Ensino de Ciências e Matemática, 2010) pela USP. Realizou estágio de doutorado na Universidade de Paris VII Dennis Diderot, período em que colaborou com o Laboratório SPHERE - Sciences, Philosophie e Histoire. Tem experiência nas áreas de Educação, Filosofia e História da Ciência, atuando principalmente em pesquisas sobre História da Física nos Séculos XIX e XX; Ensino e Aprendizagem de Física Moderna e Contemporânea; Filosofia da Linguagem e Ensino; Ciência, Cultura e Identidade e Teorias Críticas de Currículo. Coordena o Grupo de Teoria e História do Conhecimento Científico e Escolar (TeHCo). E-mail: gurgel@if.usp.br 
José Cláudio Reis é doutor em Engenharia de Produção pela UFRJ. Professor Adjunto do Instituto de Física da UERJ e professor do Programa de Pós-graduação Ciência, Tecnologia e Educação do CEFET/RJ. Atua nas seguintes linhas de pesquisa: a) Ciência e Arte na Educação Científica e Tecnológica; b) História e Filosofia da Ciência e Formação de Professores. E-mail: joseclaudioreis63@gmail.com

Karla Rampim Xavier é psicóloga e psicanalista. Mestre pelo Núcleo de Pesquisa Psicanálise e Sociedade do Programa de Estudos Pós-Graduados em Psicologia Social da Pontifícia Universidade Católica de São Paulo (2013), tem graduação em Psicologia pelo Centro Universitário de Santo André (2006). Psicanalista em formação pela Escola de Psicanálise dos Fóruns do Campo Lacaniano, do Fórum do Campo Lacaniano de São Paulo. Membro do movimento Psicanalítico do ABC. Tem experiência na área de Psicanálise e Psicologia Social, com ênfase na relação entre Subjetividade, Sujeito e Sociedade, atuando principalmente com os seguintes temas: Clínica Psicanalítica de Orientação Lacaniana, Psicologia Social, Sintoma Social, Marx e Mal-estar. E-mail: karla.rampim@gmail.com

Luciana Zaterka é licenciada e bacharel em Química pela Universidade Presbiteriana Mackenzie (1991), bacharel em Filosofia pela Universidade de São Paulo (2001), mestre em Química Orgânica pela Universidade de São Paulo (1995), mestre em Filosofia pela Universidade de São Paulo (1998), doutora em Filosofia pela Universidade de São Paulo (2003) e pós-doutora em História da Ciência pela PUC-SP (2007). Atualmente, é professora de Filosofia na Universidade Federal do ABC. Desenvolve pesquisas nas áreas de Filosofia Moderna e Teoria do Conhecimento. Pesquisa 
com maior ênfase as obras dos seguintes autores: Francis Bacon, Bento Espinosa, Robert Boyle, John Locke e Friedrich Nietzsche. Tem interesse também na área de História e Filosofia da Química, especialmente nas diferentes teorias da matéria presentes na modernidade. E-mail: luciana.zaterka@ufabc.edu.br

Márcia Helena Alvim é bacharel e licenciada em História pela Universidade Estadual de Campinas (1997-2001), com mestrado (2001-2003) e doutorado (2003-2007) pelo Instituto de Geociências da UNICAMP, área de História das Ciências. Atualmente, é professora de História da Ciência na Universidade Federal do $A B C$, desenvolvendo pesquisas sobre os seguintes temas: Conhecimentos sobre o Mundo Natural do Século XVI, Interfaces entre História das Ciências e Ensino de Ciências e Conhecimentos Indígenas numa Perspectiva de Educação Científica Multicultural. E-mail: marcia.alvim@ufabc.edu.br

Marco Braga é doutor em Engenharia de Produção pela COPPE-UFRJ e trabalha no Programa de Pós-Graduação em Ciência, Tecnologia e Educação do CEFET/RJ. É autor de 12 livros de divulgação da História da Ciência e da Tecnologia e se dedica hoje aos estudos da Cibercultura. E-mail: marcobraga.pq@gmail.com

Maria Elice Brzezinski Prestes é professora Associada do Departamento de Genética e Biologia Evolutiva do Instituto de Biociências da Universidade de São Paulo. Entre outras disciplinas, ministra "Estágio com Pesquisa no Ensino de Biologia" na graduação e "História da Biologia e Ensino" na graduação e pós-graduação. É tesoureira da Associação Brasileira de Filosofia e História da Biologia (ABFHiB) e editora do periódico Filosofia e História da Biologia. É autora de A investigação da natureza 
no Brasil-Colônia (2000) e Teoria celular: de Hooke a Schwann (1997) e co-autora de Florestas Brasileiras (2003, 2008). Coordena o Grupo de Pesquisa em História da Biologia e Ensino do IB-USP. Desenvolve pesquisas na área de História da Biologia, com ênfase no século XVIII, e de abordagens da História da Biologia na formação de professores e aplicações no ensino de ciências e biologia. E-mail: eprestes@ib.usp.br

Paluana Curvelo Luquiari é bacharel em Ciências e Humanidades pela Universidade Federal do ABC (2014); bacharel e licenciada em Filosofia pela mesma instituição, nos anos de 2014 e 2015, respectivamente. Ingressou no Programa de Pós-Graduação em Filosofia (Mestrado), no ano de 2015, para dar continuidade no desenvolvimento de suas pesquisas nas áreas de Epistemologia e de História e Filosofia da Ciência, voltadas, em especial, à Filosofia Natural e à Revolução Científica dos Séculos XVI e XVII, as quais tiveram início na graduação, com três projetos de iniciação científica: "Filosofia natural e método em René Descartes", "A defesa galileana do copernicanismo" e "A luz e o observador: um estudo da teoria de óptica de Descartes". Atualmente, seu projeto visa compreender o contexto que levou a um aumento no rigor científico na época; para tanto, considera os papéis destinados aos valores cognitivos e valores sociais, bem como os métodos utilizados no desenvolvimento e na defesa de sistemas cosmológicos alternativos ao sistema aristotélico-ptolomaico, tendo como referência, principalmente, Tycho Brahe e Galileu Galilei. E-mail:pluquiari@aluno.ufabc.edu.br

Paulo Alves Porto é bacharel e licenciado em Química pela Universidade de São Paulo (1989), possui mestrado (1994) e doutorado (1998) em Comunicação e Semiótica pela Pontifícia 
Universidade Católica de São Paulo (PUC-SP), na área de História da Ciência. Realizou estágios de pós-doutoramento na Johns Hopkins University (EUA) e na PUC-SP. É livre docente (2013) na área de Ensino de Química pelo Instituto de Química da USP. Foi professor no Instituto de Química de São Carlos (IQSC-USP) e no Programa de Pós-Graduação em História da Ciência da PUC-SP. Recebeu o J. Worth Estes Prize da American Association for the History of Medicine em 2004. Atualmente, é professor no Instituto de Química da USP, onde coordena o Grupo de Pesquisa em História da Ciência e Ensino de Química (GHQ). É um dos editores do periódico Química Nova na Escola. Tem experiência na área de História da Ciência, com ênfase em história da Química, dedicando-se a estudos que visam a aproximar a História da Ciência ao ensino de Química nos níveis médio e superior. E-mail: palporto@iq.usp.br

Paulo Tadeu da Silva é bacharel, licenciado, mestre e doutor em Filosofia pela Universidade de São Paulo. Professor adjunto da Universidade Federal do $A B C$, com atuação na área de Filosofia da Ciência, Epistemologia e História da Filosofia Moderna. Credenciado aos programas de pós-graduação em Ensino e História das Ciências e Matemática, Filosofia e Mestrado Profissional em Filosofia da Universidade Federal do ABC. Membro da Associação Filosófica Scientiae Studia e do GT Filosofia, História e Sociologia da Ciência e da Tecnologia da Associação Nacional de Pós-Graduação em Filosofia (ANPOF). Sua pesquisa está voltada para o estudo da Filosofia e da Ciência desenvolvidas durante o século XVII, em especial nas obras de Galileu, Mersenne e Descartes. Nesse contexto e autores, desenvolveu pesquisas relacionadas com a natureza da revolução científica do período moderno, a defesa do copernicanismo, o desenvolvimento do 
mecanicismo e as relações entre a Metafísica e a Filosofia Natural.E-mail: paulo.tadeu@ufabc.edu.br

Renato Barboza é professor adjunto da Universidade Federal de São Paulo (UNIFESP). Graduado em Ciências Biológicas pela Universidade de São Paulo (Bacharelado e Licenciatura). Mestre e Doutor em Imunologia pela Universidade de São Paulo. Pós-doutorado em Parasitologia pela Universidade de São Paulo. Atualmente é docente do curso de Graduação em Ciências da UNIFESP, Diadema. É orientador do Programa de Pós-Graduação em Ensino de Ciências e Matemática (PECMA), da UNIFESP. Faz parte do grupo de pesquisa História das Ciências na Educação Científica (HSSE). Desenvolve pesquisas nas áreas de Imunologia, História e Filosofia da Ciência, Formação Inicial de Professores de Biologia e no Ensino de Biologia. E-mail: renato.barboza@unifesp.br

Simone Alves de Assis Martorano é professora adjunta da Universidade Federal de São Paulo (UNIFESP). Mestre e Doutora em Ensino de Ciências - Modalidade Química, pela Universidade de São Paulo. Licenciada em Química pela Faculdade de Filosofia Ciências e Letras Oswaldo Cruz e Bacharel em Engenharia Química pelo Centro Universitário da FEl. Atualmente, é docente do curso de Graduação em Ciências da UNIFESP, Diadema. Coordenadora e orientadora do Programa de Pós-Graduação em Ensino de Ciências e Matemática (PECMA) da UNIFESP. Faz parte do grupo de pesquisa História das Ciências na Educação Científica (HSSE). É editora de seção da Revista SEMINA: Ciências Exatas e Tecnológicas. Desenvolve pesquisas nas áreas de Ensino de Química, História e Filosofia da Ciência, Formação Inicial e Continuada de Professores de Química e na Elaboração de Materiais Didáticos para o Ensino Médio. E-mail: simone.martorano@unifesp.br 
Suseli de Paula Vissicaro é pedagoga, mestre em História das Ciências e Ensino pela UFABC e doutoranda em Ensino de Ciências pela UNICAMP. É professora dos anos iniciais do Ensino Fundamental, na rede municipal de São Bernardo do Campo, onde atua também como Formadora e Orientadora de Estudos do Pacto Nacional pela Alfabetização na Idade Certa. Desenvolve pesquisas na área de Formação de Professores e na utilização da História das Ciências no Ensino das Ciências. E-mail: svissicaro@gmail.com

Thaís Cyrino de Mello Forato é professora adjunta na Universidade Federal de São Paulo, docente do curso de Graduação em Ciências - Licenciaturas em Física, Química, Biologia, Matemática, no campus Diadema. Possui doutorado em Educação pela Universidade de São Paulo, mestrado em História da Ciência, bacharelado e licenciatura em Física pela Pontifícia Universidade Católica de São Paulo. Coordenadora do grupo de pesquisa História das Ciências na Educação Científica (HSSE). Atualmente, realiza o pós-doutoramento em Ensino de Ciências no Instituto de Biologia da Universidade de São Paulo, junto ao Programa de Pós-Graduação Interunidades em Ensino de Ciências, modalidades Física, Química e Biologia. É orientadora de pós-graduação nos programas: Pós-Graduação em Ensino de Ciências e Matemática (PECMA - UNIFESP); Pós-Graduação em Ensino e Histórias das Ciências e da Matemática (PEHCM UFABC); Pós-Graduação Interunidades em Ensino de Ciências (PIEC-USP). Editora adjunta de Prometeica - Revista de Filosofia y Ciência, uma parceria entre pesquisadores da Argentina e do Brasil. Desenvolve pesquisas em História das Ciências no Ensino; História das Ciências na Formação Inicial e Continuada de Professores de Ciências. E-mail: thaiscmf@gmail.com 
Winston Gomes Schmiedecke possui graduação (bacharelado e licenciatura) em Física pela Pontifícia Universidade Católica de São Paulo (1991), mestrado em História da Ciência pela Pontifícia Universidade Católica de São Paulo (2006) e doutorado em Ensino de Ciências (modalidade: Física) pela Universidade de São Paulo (2016). Atuou por mais de duas décadas como professor de Física em cursos de nível fundamental, médio e pré-vestibulares da iniciativa privada e, desde 2009, é professor do Instituto Federal de Educação, Ciência e Tecnologia de São Paulo. Colabora desde 2010 com o Instituto Nacional de Estudos e Pesquisas Educacionais Anísio Teixeira (INEP), na condição de coordenador de equipe, revisor e elaborador de questões de Ciências da Natureza e suas Tecnologias do Exame Nacional do Ensino Médio (ENEM). Desenvolve trabalhos na área de História da Ciência, com ênfase nos estudos relacionados à Ciência Nacional e suas interlocuções com o Ensino de Física. E-mail: winston.fisica@gmail.com 